\title{
DEMOLITION AND RELOCATION OF HINDU TEMPLES IN MALAYSIA: \\ PRAGMATIC RESPONSES OF INDIAN HINDU COMMUNITIES IN PENANG
}

\author{
BY
}

\section{TEO SUE ANN}

\begin{abstract}
A thesis
submitted to the Victoria University of Wellington

in fulfilment of the requirements for the degree of

Doctor of Philosophy
\end{abstract}

Victoria University of Wellington

(2018) 



\section{ABSTRACT}

This thesis examines the pragmatic responses of Indian Hindus when their century-old Hindu community temples face threats of demolition by the Malaysian government. I argue that their compliance with the demolition is a subtle and pragmatic political act that manipulates their political standing as a minority community in order to safeguard their temples. I analyse the effectiveness of such pragmatic acts of compliance by the Indian Hindu communities, and the implications of their compliance for the political and social significance, as well as the sacredness of their demolished temples.

My ethnographic data is derived from in-depth interviews of the management committees and community members of three Hindu temples in Penang, and field observations of the rituals and ceremonies in these temples. During my fieldwork, these temples have either been demolished or are in the process of demolition. The management committees of these temples have relocated the statues of the deities into temporary buildings. My findings show that the Indian Hindu communities acquiesced to government demolition of their community Hindu temples to make way for development. In return for their compliance, the Hindu communities expected that the government is obligated to find new locations for them to rebuild their community temples. Their attempts to ensure the temples continuously exist in the area suggest that these temples, regardless of their shapes and sizes, have significance for the local Hindu communities. This significance it true both for members of the temple committee and the local Hindu community. Their compliance also suggests that the portability of these temples as sacred places.

The importance of the thesis is in its insistence that Malaysian Indian Hindus as minorities are not necessarily powerless in the face of dominance of the government. Instead, these Hindu communities are actively engaging with their political and social realities with pragmatic and subtle political actions such as demonstrating compliance. By complying with the demolition of their community temples, the Hindu communities are not only able to manoeuvre their ways through the dominance of the government, but they can also Hindu communities. 



\section{ACKNOWLEDGEMENTS}

This thesis is the result of the willingness and generosity of the participants to share with me their opinions and experiences, especially while they are in the midst of ensuring their community temples will continue to exist. They have my gratitude for their input, time and cooperation that have made this thesis possible.

I am grateful to my supervisors Dr Rick Weiss and Prof. Joseph Bulbullia. Their support, patience, guidance and perseverance have been consistent throughout my PhD journey. Their supervision, comments and expertise have enabled me to grow academically. Dr Rick Weiss, who doesn't hold back his constructive criticisms, has constantly challenged my intellectual boundaries and has enabled me to grow intellectually and emotionally. Through his guidance, I have confronted my limitations and weaknesses. His advice will remain valuable in my academic pursuits. I am grateful to Prof. Joseph Bulbulia, my secondary supervisor, who has given me much needed positive encouragement. His advice and critical comments have enabled me to see the course of my project more clearly.

Throughout this journey, I have been very fortunate to have had a support team to keep my sanity anchored. Abri, who supported and encouraged me to pursue this PhD in New Zealand, and who has endured with patience all the challenges of the journey. I thank my family for understanding the necessity of my pursuing this degree, and for their support. I appreciate and am grateful to my friends for their reassurances and enthusiasm.

I have been very fortunate to have landed at the doorstep of the Religious Studies Programme at Victoria University. For the last four years, the Department has been my home far away from home. I especially would like to acknowledge Aliki Kalliabetsos, for her support, understanding, friendship and care. I am grateful for the working environment that is intellectually stimulating, caring and supportive. The friendships that I have made will remain with me. Last but not least, I would like to acknowledge the financial contributions from the William Wallace Gibson Memorial Scholarship, the Victoria PhD Submission Scholarship and the Victoria Hardship Funds and Equity. Special thanks to the advisors from Student Learning Support for their helpful guidance in improving my English writing skills. 



\section{Contents}

List of Abbreviations..................................................................................................................ii

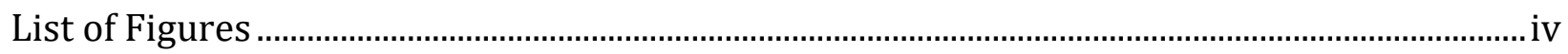

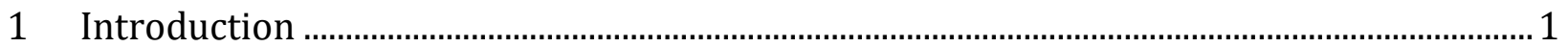

1.1 Literature Review and Contribution of this thesis .......................................................... 3

1.1.1 The non-confrontational responses of the Indian Hindus ......................................... 3

1.1.2 The significance of Hindu temples........................................................................ 13

1.1.3 Hindu temples as sacred places................................................................................... 18

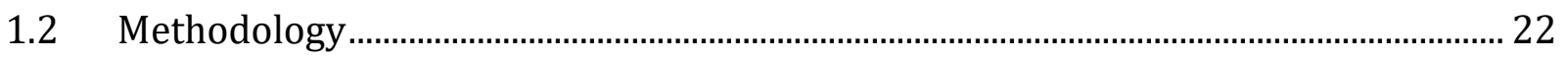

1.3 Thesis limitations .......................................................................................................... 27

$1.4 \quad$ Organisation of chapters.................................................................................... 31

2 The politics of the issue of Hindu temple demolition ............................................................ 32

2.1 Indian Hindus as powerless minorities in Malaysia ...................................................... 33

2.1.1 History of Indian Hindus and the illegality of Hindu temples in Malaysia .......... 34

2.1.2 Dynamics and frictions among Malaysian Indian Hindu communities................. 40

2.1.3 Political Marginalisation of Indian Hindus in Malaysia ............................................. 44

2.1.4 Religious Marginalisation of Malaysian India ………………………………......... 48

2.1.5 Socio-economic Marginalisation of Indian Hindus ................................................. 53

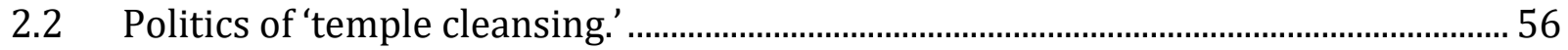

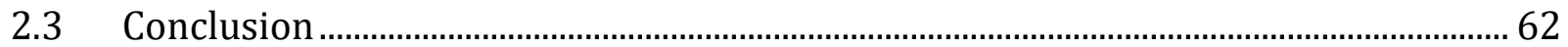

3 Local politics of Hindu temples destruction in Penang ...................................................... 65

3.1 Penang under the governance of the Democratic Action Party (DAP) ......................... 66

3.2 History of land ownership in Penang ………………………………………………... 76

3.3 The Penang Hindu Endowment Board (PHEB) …………………………….............. 80

3.4 Conclusion ............................................................................................................ 84

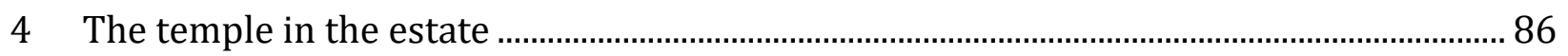

4.1 Historical narratives and previous events of the temple............................................... 88

4.2 The process of demolition and relocation of the temple............................................. 95

4.3 Political rivalry between the DAP and the BN government......................................102

4.4 Reactions of the estate Hindu community towards the demolition of the temple107

4.5 The endangered significance of the temple..................................................................114

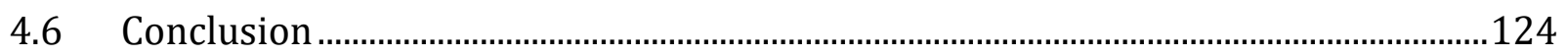


$5 \quad$ The temple for the council workers ................................................................................

$5.1 \quad$ The successful demolition and relocation of this temple..........................................131

5.1.1 The historical, political and social significance of the temple ..............................132

5.1.2 Conformity and compliance as pragmatic and tactical acts .................................139

5.1.3 Ongoing negotiation and limits to conformity ..................................................... 144

5.2 Spatial claims of the new location............................................................................148

5.2.1 Ritual performance for relocation and spatial claim of the new location..........149

5.2.2 Building the Agamic temple as a spatial claim....................................................... 160

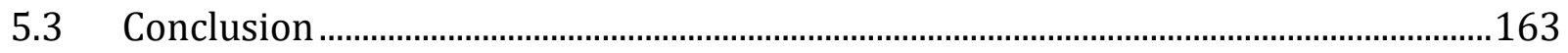

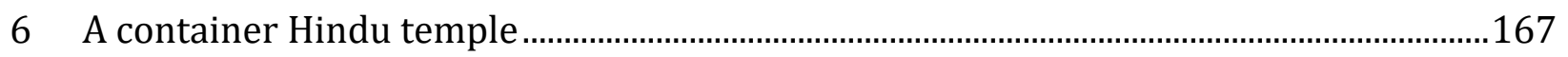

6.1 The communal and religious significance of the temple...........................................170

6.2 Demolition and relocation of the temple.......................................................................174

6.3 Clientelism and partnership with the state government..........................................187

6.4 To maintain the temple as the communal and religious centre .................................193

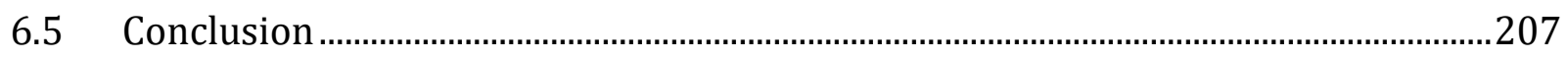

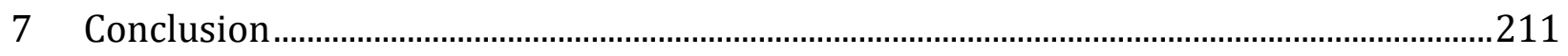

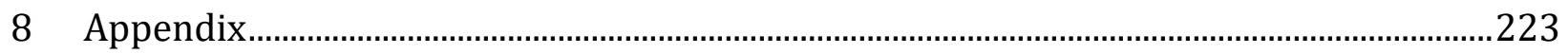

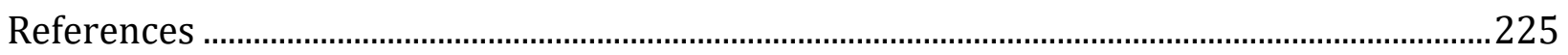




\section{List of Abbreviations}

ABIM Muslim Youth Movement of Malaysia (Angkatan Belia Islam Malaysia)

BN National Front (Barisan Nasional)

DAP Democratic Action Party (Parti Tindakan Demokratik)

EXCO Executive Councillor

HINDRAF Hindu Rights Action Force

JKR Department of Public Works (Jabatan Kerja Raya)

MIC Malaysian Indian Congress

PAS Pan-Malaysian Islamic Party (Parti Islam Se Malaysia)

PKR People's Justice Party (Parti Keadilan Rakyat)

PR People's Alliance (Pakatan Rakyat)

RIBI Non-Islamic Houses of Worship (Rumah Ibadat Bukan Islam)

UMNO United Malays National Organisation (Pertubuhan Kebangsaan Melayu Bersatu)

YB The Honourable (Yang Berhormat) 



\section{List of Figures}

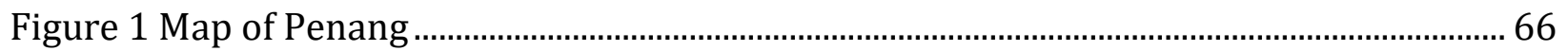

Figure 2 The demolished Kaliamman temple in the estate (Photo taken during fieldwork) 98 Figure 3 The temporary Sri Kaliamman temple of the estate, Penang (Photo taken during

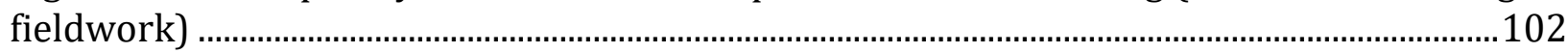

Figure 4 The temporary structure to house the statue of the Goddess ....................................109

Figure 5 Statues of the deities in the temporary temple (Photo from fieldwork) ..................115

Figure 6 Essence of the deities in sacred vases........................................................................152

Figure 7 The two-window container temple..........................................................................170

Figure $8 \mathrm{~A}$ photo of the Kaliamman temple before demolition, taken by the family (Photo shown by Kumar during the interview).

Figure 9 The former location of the temple after the demolition and relocation of the

Kaliamman temple (Photo from fieldwork)

Figure 10 The playground opposite the temple, which according to Kumar used to be on RIBI land (Photo from fieldwork).....

Figure 11 The statue of the goddess Kali, which worshippers carried out to fight the demon on the last day of the Navratri (Photo from fieldwork). 



\section{Introduction}

This thesis is about the destruction of Hindu temples in Malaysia. Although incidents of the demolition of Hindu temples by the Malaysian government are not new, the on-going demolition has gained momentous political significance since the 2000s. I examine the experiences of Malaysian Indian Hindus, particularly those of the lower and working classes to the threats of the demolition of their temples. I argue that the Indian Hindu communities as minorities are not powerless in a Malay Muslim-led country. Instead, they manipulate their political surroundings by leveraging their social positions as minorities.

This thesis examines three demolished Hindu temples in Penang. I focus on the pragmatic responses of Hindus, namely, their compliance with the demolition and relocation of their community Hindu temples by the government. These demolished Hindu temples were illegally situated on government land. Participants in this thesis have not only accepted the fact that their community Hindu temples are situated on the government lands. They have also acknowledged that their temples have to be demolished to make way for development. Moreover, they have willingly complied with the arrangement by the government to house the statues of the deities in temporary shelters. Besides their compliance, the Indian Hindu communities also demonstrate their conformity by forging political alliances with the government. In one instance, the management committee even set the stage for the politicians to promulgate their political agenda. I explore the motivations of their conformity and compliance with the government. I ask: How do these pragmatic approaches enable Hindus to safeguard their religious freedom and rights from encroachment by the government? How do the Hindu communities manipulate political alliances to safeguard their temples?

The threats of demolition have also revealed the important roles that the management committee and members of the local Hindu communities play in establishing and maintaining the social significance of their community temples. Generally, both the management committee and local Hindu communities have claimed that the temples have 
served their religious needs for generations. Such generational claims emphasise the longstanding legacies of the demolished Hindu temples. Nonetheless, my analysis has also shown that the request for demolition by the government has lain bare the power relations between the management committee as the patrons of the Goddesses and members of the Indian Hindu communities as devotees. For instance, the management committees as patrons of the Goddesses, have also assumed higher social positions among the local Indian Hindu communities which the temples serve. Therefore, the temples are not only important for them as abodes for the Goddess but also as sources for social influence to establish and maintain their higher social positions among Indian Hindu. Hence, the management committees require the local Hindu communities to identify the temples as their community Hindu temples, especially after the demolition and relocation. In the three case studies, I examine how the management committees juggle between complying with the government for demolishing the temples and maintaining the social significance of these temples for the local Hindu communities, especially after the demolition and relocation.

The acquiescence for the demolition and relocation of these temples by the Indian Hindu communities also suggests that these Hindu temples as sacred places are portable. The portability of these temples would neither affect their beliefs in the divinity nor the historical significance of these temples. Above all such willingness for relocation indicates that the sacredness of the temples is constructed and maintained by the Indian Hindu communities themselves based on their political and social experiences. Therefore, I investigate how the Indian Hindu communities have reconstructed the sacredness of these temples to justify the drastic changes due to the demolition and relocation.

My analysis of the three case studies will focus on the diversity of conformity and compliance approaches. I demonstrate how their pragmatic approaches reveal and influence the existing tensions, frictions or cooperation within each of the Indian Hindu communities, as well as between the Indian Hindu communities with the government. Their diverse approaches reflect their different intentions and priorities that subsequently shaped the way they engaged with the DAP-led state government. In the next section, I 
review the existing scholarly literature that touches on the three main areas in which this thesis will contribute.

\subsection{Literature Review and Contribution of this thesis}

In this section, I review the literature to identify the knowledge gaps in the previous studies. I begin with the literature review that associates conformity and compliance with subtle and indirect political acts. Then, I review previous studies concerning the political, social and religious significances of a Hindu temple and the concept of a sacred place.

\subsubsection{The non-confrontational responses of the Indian Hindus}

I begin this section by reviewing the existing scholarly literature in identifying the various indirect and subtle political actions that subordinate groups have taken to manoeuvre their ways through the webs of hegemonic power of the authorities. I suggest that the Indian Hindu communities in Malaysia, despite being the minorities that often appear to be docile and submissive have agency. Agency in this context refers to "a capacity for action that historically specific relations of subordination enable and create" (Mahmood 2001, 202). I also explore the existing literature to identify the effectiveness of such indirect and subtle acts that were implemented by subordinate groups in achieving their hidden agendas. Subsequently, I review previous studies to identify the past indirect and subtle acts undertaken by Indian Hindus in Malaysia that have been left unnoticed by many scholars. I discuss the importance of taking these subtle and indirect acts by the Indian Hindus into account in comprehending the complexity of this issue.

Studies have found that subordinate minority groups often prefer non-confrontational acts to manipulate the political situation and safeguard their basic freedom and rights. For instance, according to Holmes (1982), tactical behaviours of compliance, cooperation and conformity were employed by minority Catholics as early as the 1500s. and also observed that while the Catholic leaders showed their conformity to the Queen in public, they also gave subtle rebellious hints in their public religious speeches and books during the beginning of Elizabeth's reign. However, as Elizabeth's reign stabilised over time, the Catholic leaders responded by urging the Catholics to give their full support to the Queen. 
After establishing a public reputation of being meek and having unwavering loyalty to the Queen, the Catholic leaders then criticised the majority Protestants as rebellious, while the minority Catholics remained as supportive subjects of the Queen. The Catholics' appearance of conformity not only won public favour but also managed to negate threats against their religious freedom and identity in the majority Protestant society. Their apparent conformity was effective because of how it complemented their minority position in their political surroundings. The conformity of the Catholic minority also took the time to appear convincing to the reigning government. During this period, Catholic leaders, papists and scholars published books emphasising similarly that Catholics are taught to be obedient to their political authority more firmly than Protestants (Holmes 1982,13). The Abbot of Westminster even openly urged the Queen to reject Protestants as rebels. Holmes (1982) argues that such demonstration of conformity to the queen was practical, to ensure the safety of the populist minorities that remained in England while most of the Catholic followers were in exile. By demonstrating conformity and an apolitical stance, the remaining Catholic leaders could also earn leeway to appeal for mercy and request for toleration from Queen Elizabeth (Holmes 1982, 64). Moreover, the non-resistant approach also strengthened the Catholic belief that this was a way to convert England by suffering and not force (Holmes 1982, 64). As such, political context (as in the case of the emerging political dominance of Elizabeth's reign) has become one of the crucial factors in understanding the minority groups' submissiveness and meekness as pragmatic moves. Holmes (1982) further argues, the Catholic leader found that political plotting and ideology loyalism though may appear to be going in a different direction on the surface. Beneath the surface, they were heading in the same direction - "the preservation and eventual recovery of Catholicism in England" (64).

In this thesis, I suggest that the political setting in Penang is an important factor in determining the effectiveness of the conformity and compliance of the Indian Hindus in the three case studies. Their compliance and meekness are often equated with their underprivileged position in Malaysian society. Such underprivileged position complemented with the political principles of the Democratic Action Party (DAP) that vows to assist the poor and underprivileged groups in Malaysian society. Moreover, DAP was the 
only opposition party that openly expressed its support for the campaigns by HINDRAF (Hindu Rights Action Force) (Lee 2008, 191). HINDRAF was a coalition of fifty Hindu nongovernmental organisations, which alleged that the Malay Muslim-led government had been demolishing a Hindu temple every three weeks (Hamid 8 November 2007). Even though the demolished temples were illegally situated on private or government lands, the Hindu leaders alleged that the government was undertaking the operation of 'temple cleansing'. They alleged the demolitions are discriminations against the religious rights and freedom of the local Indian Hindu minorities (The Financial Express 23 May 2006).

Under this political context, the conformity and compliance of the management committee of these temples have enabled them to obtain the government's agreement in allocating a new place for them to rebuild their community temple. As I will demonstrate across the three case studies, the management committee of these temples was aware of the political interests shown in the issue of Hindu temples demolition in Malaysia. They were also aware of how the DAP-led state government agreed with HINDRAF and opposed the BN-led government for demolishing the Hindu temples in Malaysia. Hence, I argue that the management committee could manipulate the political positions of DAP due to the political interests involved in the issue. Therefore, they could manoeuvre their ways through the hegemony of the DAP-led state government. This eventually led to agreement from the DAP-led state government to relocate their community temples.

A study by Tjosvold and Huston $(1978,58)$ further suggests that it important for the subordinates to comprehend their social positions within the same political context as the dominant groups. Their comprehension of the social and political context shape how they show compliance and conformity to the dominant groups. For instance, Tjosvold and Huston (1978) found that conformity is one way for less advantaged or the "low-status bargainers" to 'validate' the position of more advantaged groups known as "high-status bargainers". Their validation makes the high-status bargainers feel less affronted and, hence, more willing to compromise in return (Tjosvold and Huston 1978). On the surface, the compromising attitudes of the low-status bargainers seemed to denote their submissiveness to the hegemony of the high-status bargainer. Beneath their 
submissiveness, however, the low-status bargainers often possess an agenda that is covert and implicit. As such, the validation of the low-status bargainers has enabled them to manipulate negotiations to achieve a consensus that meets or brings them closer to their often-covert objectives. Hence, their compliance is perceived as a tactical and strategic move in manoeuvring their ways through the hegemonic power relations with the highstatus bargainers. For this reason, I suggest that the effectiveness of conformity and compliance as tactical moves is determined by the understanding of social positions between both parties within a political context. As Tjosvold and Huston (1978) suggest, both parties have to be situated in a similar context for the lower status bargainers to understand the importance of showing conformity to the upper-status bargainers.

In this thesis, I also suggest that it is particularly effective for the Indian Hindus to show that they are powerless and meek because the general reputation of the Indian Hindus in Malaysia as being passive and subservient is historically rooted. Malaya (the former name of Malaysia before 1963) experienced an influx of Indian Hindus migrants during the colonial period in the $19^{\text {th }}$ century. ${ }^{1}$ It was precisely because of their compliant attitude that the European planters and the British colonial government had encouraged the influx of Indian labourers to Malaya to work as labourers, particularly in estates and plantations and to build railroads (Sandhu 1969). The European planters and the British colonial government have observed that due to their submissiveness, these Indian labourers were easier to be manipulated compared to the Chinese or Malay labourers (Sandhu 1969, 56; Arasaratnam 1979; Netto 1961; Morrison 1949). These Indian labourers were also seen as "cheap and reliable" (Polak 1941, 88), and not as ambitious as the other Northern Indians and Chinese migrants. They were amenable to the low salaries and adjusted better to the low standard of living (Sandhu 1969, 57). Hence, they were deemed as the most suitable workers used for manual labour.

Nonetheless, I argue that such notion of submissiveness as docility of Malaysian Indian Hindu minorities was not solely derived from the British government and European

\footnotetext{
${ }^{1}$ Malaya was a former name for Malaysia prior to 19 September 1963. It included the Peninsula and Singapore. Malaysia is formed after the inclusion of Singapore, Sabah (was known as the North Borneo) and Sarawak. Singapore left Malaysian in 9 August 1965.
} 
planters. The Indian Hindu labourers also contributed to this perception of their submissiveness as docility. This is because the Indian labourers often chose not to retaliate with the Chinese labourers against the European employers demanding higher wages and better living conditions in the estates and plantations (Ramasamy 1992). Although they had not joined in the protests, it is by no means that the Indian labourers were docile and easily manipulated as the European planters and the British government preferred them to be. Scholars have noted that the European planters often faced problems of labourers fleeing the estates before completing their contracts during the $19^{\text {th }}$ century (Ramasamy 1992; Arasaratnam 1979; Sandhu 1969; Jain 1993). According to Pillai (20007), the European planters were anxious about the serious problems of desertion by the Indian labourers and were compelled to find ways to coerce the Indian labourers to remain in the estates and plantations. Pillai (2007) argues that "the execution of colonial power was obviously on the collaboration of the colonised" (50). She found that the European planters were often juggling between artful coercions of the labourers and safeguarding their domain of supremacy (50). This is because the European planters realised that successful coercions of the labourers encouraged labour productivity. Pillai's findings are crucial to demonstrate that the labourers, especially the Indian labourers were never passive with their surroundings. They were capable of using their knowledge to manipulate situations, such as the desire of their employers to maximise profits, to benefit their conditions.

After Malaya gained Independence in 1957, many of these Indian Hindu labourers had descendants in Malaya. Sandhu $(1969,167)$ found that the recorded Indian population in Malaya in 1957 was 820,270 people, with only 311,000 (around thirty-eight per cent) identifying as Indian immigrants or born in India. ${ }^{2}$ These Indians made up about eleven per cent of the total Malaysian population, and about eighty per cent of them were Hindus (Sandhu 1969, 175). They were the third largest racial group, after Malays and Chinese. According to the Hindu leaders, despite gaining Independence, the colonial perceptions of the Indian Hindu lower and working classes were still carried on. Due to their apparent

\footnotetext{
${ }^{2}$ Sandhu $(1969,167)$ also notes that the high possibility of discrepency in the immigration numbers, even though similar numbers of immigrants were stated in other census records. He contends that the net immigration is less than the actual numbers of Indians.
} 
submissiveness and minority status, the majority of Indian Hindu communities continued to be perceived as docile in the multiracial and Malay Muslim-led country by the Indian leaders, politicians and even the scholars. Gill and Gopal $(2010,137)$ noted how the Indian Hindu leaders had claimed that "Indians in Malaysia, who have lived in Malaysia for up to five generations in many cases, find ourselves hemmed in and blocked by a racist and religious extremist Malaysian Government". Gill and Gopal $(2010,139)$ further argue this point: "to protect their culture and religion from external forces, which are constantly impinging on the sovereignty of their respective religions, Malaysian Indians have become more introverted and, to some extent, paranoid about race-religious relations, especially amongst the younger generation". The Indian Hindus' reputation of being introverted are what make the conformity and compliance of the Indian Hindus in the three case studies of this thesis seem convincing.

It is apparent that the Indian communities, particularly those from the lower and working classes continue to react subtly and indirectly to the Malaysian political and social conditions. As I have suggested in this thesis, one of their subtle and indirect acts was to reinforce their meekness and powerlessness through their compliant and conformist attitudes. Scott (1990) insists that "the powerless have... a self-interest in conspiring to reinforce a hegemonic appearance" (xii). He argues that "the powerless are often obliged to adopt a strategic pose in the presence of the powerful" (xii). One of Scott's examples of the "strategic pose in the presence of the powerful" is conformity, which he argues is one form of "public transcripts". ${ }^{3}$ Besides, the effectiveness of public transcripts by the subordinates also reflects reciprocal power relations between them and the dominant group. As Scott (1990, 3-4) argues, while the subordinates are performing deference and consent, the dominants are also performing mastery and command. The purpose for such reciprocate performances between them is to observe, to discern and to read the intentions and moods of their counterparts. For the subordinates, their intentions were to observe the intentions and moods of the potentially threatening dominant groups. For the dominants, they

\footnotetext{
${ }^{3}$ Scott (1990) defines 'public' as "action that is openly avowed to the other party in the power relationship, and 'transcripts' is used almost in its juridical sense (proces verbal) of a complete record of what was said. This complete record, however, would also include non-speech acts such as gestures and expressions" (2).
} 
attempted to discover the underlying intentions of the surface compliance of the subordinates (Scott 1990, 3-4). Although the state government is not included in this study, the diverse responses of the Indian Hindu communities in the three case studies often reflect the different attitudes of the state government in each case. The fact that the conformity and compliance of the Indian Hindu communities have enabled them to prevent their temples from being permanently destroyed further suggest the public transcript of the state government. I will further analyse the possible public transcripts of the state government in Chapter Three.

By focusing on the issue of Hindu temples demolition in Malaysia, I further suggest that the Indian Hindus have often responded in indirect manners that reinforce the hegemonic appearance of the government. For instance, it is important to note that cases of Hindu temples demolition in Malaysia are not new. The issue has emerged since Malaysia was influenced by the 1970s Islamisation movement from the Middle East. Since then, the Malay Muslim-led local authorities have imposed heavy bureaucratic processes on acquiring permission for the construction of non-Islamic religious buildings. The red-tape for establishing non-Islamic religious buildings required the non-Muslims to obtain approvals from the local authorities and the State Islamic Council. This bureaucratic process in obtaining approvals was initiated by the Malay Muslim-led government after the intention of shrine control was put across in 1983 (Lee 1988). According to Lee (1988, 411), the government expressed the need for 'shrine control' by specifically targeting the Chinese and Hindu shrines as well as the Christian churches in Petaling Jaya and Klang. The local authorities were concerned that worshippers could make de facto claims for the land, which their religious buildings were located on. These non-Islamic buildings were claimed to hinder urban renewal projects. Nevertheless, after an announcement was made on the supposedly 'shrine control', no subsequent news was reported on its implementation. Instead, the government legislated guidelines for establishing non-Islamic religious buildings that obstructed non-Muslims from acquiring land for religious purposes (Lee 1988). Lee (1988) also observed that after the government's intention on 'shrine control' was conveyed, the Municipal Council of Petaling Jaya served eviction orders to forty-six non-Muslim religious groups, citing the improper use of buildings under the Street, 
Drainage and Building Act of 1974. As a result, the non-Muslims found it increasingly difficult to acquire land for religious purposes (Lee 1988). Non-Muslims believed that the government's intention of 'shrine control' was an encroachment of the Malay Muslim-led government against their religious rights and freedom. Willford $(2013,137)$ argues that Hindu temples were the hardest hit by the proposed guidelines for planning places of worship for non-Muslims. This was because many of the village temples remain unregistered and are located illegally on lands that are not owned by the temple's committees. Even though the suggested guidelines have yet to be approved, many of these Hindu temples had been demolished by the local authorities (Jha 2009, 898).

Nevertheless, according to Ramanathan $(1995,243)$, the Indian Hindus had conformed to the demolition of the wayside shrines and minor temples (some of which were on government land), "... Hindu government officers have been ordered to carry out the removal of Hindu temples, which often put them in a very delicate and difficult position" (249). He further argues that "the Indian Hindus have been restrained, or at least, have never fully shown their displeasure over the whole episode because they were perhaps cognizant of their vulnerability, having suffered political and economic marginalisation over the years" (243). Hence, the Indian Hindus responded to the domination of the Malay Muslim government "in a peaceful manner" (Ramanathan 1995, 250) by repairing, rebuilding and upgrading the existing temples. These approaches were not only employed by the Indian Hindu communities residing in urban areas, but also those living in rural areas who employed similar approaches. According to Lee and Ackerman $(1997,91)$, during the late 1970's, many Indian Hindu communities refurbished their community temples in rural areas. For example, the Mariyaman deity was found to be worshipped in the grander temples, and the Muniswaran deity could be found as an independent deity in some of the village temples.

The sense of disadvantage as minorities was especially felt by Malaysian Indian minorities with the eruption of a series of disputes between Malay Muslims and Indian Hindus, infamously known as the Kerling incident. The disputes lasted from December 1977 to August 1978. From 1977, a series of Hindu temples were desecrated by the dakwah 
(proselytisation) songsang group, which believed that the act would secure them a place in heaven (Barraclough 1983, 960; Ramanathan 1995, 240). In 1978, eight temple guards caught a group of four white-robed members of dakwah songsang desecrating the Hindu deities of a roadside temple in Kerling, Kuala Lumpur. The guards killed the four Muslim youths and were subsequently jailed for their actions. The Indian Hindu communities perceived the Kerling incident as a result of the government delay in handling the desecration of the Hindu temples. The delay from the government seemed to indicate the vulnerability of Indian Hindu communities as minorities, in a majority Malay-Muslim led country (Ramanathan 1995; Prorok 1998). Due to this minority status, the Indian Hindu communities realised that they could not afford to respond to the threat against their temples aggressively and had to rely upon themselves to safeguard their temples (Belle 2008b, 68; Ramanathan 1995, 243).

It also seems that due to the realisation of their minority status, the Indian Hindu communities decided to safeguard their temples by refurbishing their community temples. Prorok $(2015,270)$ argues that the refurbishments serve as a paramount, yet safer, mode of resistance to the political climate in Malaysia during the 1990s. Her argument suggests that the apparent powerlessness and vulnerability of the Indian Hindu communities when the government demolished their Hindu temples are their "public transcripts". Scott (1990) stresses that "public transcript is not the whole story" (3). As a result, many Hindu temples that were housing the Goddess Mariamman and Kaliamman have been refurbished into the Agamic structure. Prorok $(1998,96)$ defines an Agamic Hindu temple as a temple with three distinctive features - a vimana (the superstructure over the inner sanctum of a Hindu temple, specifically of South India), a mandapa (a prayer hall) and at least one (raja) gorupa (a towered gateway). The enhanced appearence of these Agamic Hindu temples in the Malaysian landscape has enabled the Indian Hindu communities to assert their presence and religious rights as Malaysian citizens. As a result, many temples housing village deities, such as the Goddess Mariamman, have been refurbished, especially in rural areas (Lee and Ackerman 1997, 91; Ramanathan 1995, 251). Prorok's arguments are important in highlighting how the political and social contexts are essential considerations for conformity and compliance approaches to be effective. This is because the political and 
social contexts often determine how convincing the acts of compliance and conformity by the subservient groups would appear to be.

In the contemporary context, the demolition of Hindu temples continues. Bunnell et al. (2010) discovered in their study that in Kuala Lumpur and Putrajaya during 2004 many explantation workers were forcibly evicted and their temples were demolished to make way for development. More importantly, their arguments have reiterated the powerlessness of the Indian Hindus in facing the encroachment of the government. With three case studies of demolished Hindu temples in Penang, I demonstrate that their apparent submissiveness to the demolition of their community Hindu temples does not necessarily equate to their powerlessness. I analyse how their conformity and compliance are meant "to be impressive, to affirm and naturalise the power of the dominant elites, and to conceal or euphemise the dirty linen of their rule" (Scott 1990, 18). Statements such as "What to do? We cannot stop the development because of one temple" were often echoed in the interviews. However, Scott $(2008,304)$ argues that behind the façade of symbolic and ritual compliance, such as the surrender expression of the Hindu communities in this study, there are often innumerable acts of resistance. I investigate the effectiveness of their submissive behaviour which enabled them to manage the direct threats of demolition by the DAP-led state government. I also analyse how their submissive behaviours project the dynamic and complex political realities of these three groups of Indian Hindus.

It is important to note that the willingness of the Indian Hindu communities to conform to and comply with the government is not an easy decision. This is because their conformity and compliance entail the demolition of the existing temple buildings. The demolition of these temples would further affect the existing political, social and religious significance of these temples. Nevertheless, the willingness of the Indian Hindu communities to conform and comply also suggests that they have found ways to make sense of the demolition and relocation of their community temples by the government. To understand how they have made sense of the drastic change to their community temples, I will review the existing literature about the significance of Hindu temples in the next section. 


\subsubsection{The significance of Hindu temples}

Literature about Hindu temples has shown that they are not only places of worship but also imbued with political and social significances by the devotees whom the temples serve. In this section, I argue that the diverse political and social significance of these temples depends mainly on communal relations within and among different groups of Indian Hindu communities. The importance of the communal relations also suggests that both the management committees of the temples and members of the Indian Hindu communities have important roles to play in establishing and maintaining the significance of their community temples. In this section, I will review the literature about the relationships between the devotees and the Hindu temples that shape the political and social significance of Hindu temples. I also demonstrate how the diverse political and social significance of Hindu temples are important contexts for the Indian Hindu communities in the three case studies. These contexts are important to explain how the communities employ conformity and compliance as pragmatic and strategic moves to safeguard their community temples.

The political and social significances of a Hindu temple that render it an effective social, political and religious institution require the existence of not only the external and internal political settings but also social contexts. According to Sinha $(2005,9)$, the external context such as the pragmatism, bureaucratic efficiency, rationality and need for control and regulation that impact upon all sections of society are important factors to consider when making sense of the context, historical narratives, meaning and functions of a Hindu temple. For instance, she found that many of the jungle temples in Singapore, which she had enumerated during the 1980s no longer existed, as they had either shifted or were destroyed to make way for development (Sinha 2005, 108). According to her, many of the jungle temples were also illegal, as they were unregistered and situated on land belonging to the government. More importantly, she denotes no conflict or tension that arises between the Indian Hindus and the government from the demolition issue. She stresses that the government of Singapore takes pains to ensure peaceful co-existence of different religious groups in the country. 
The study by Sinha (2005) provides an important comparison of different political climates in the issue of illegal Hindu temples between Singapore and Malaysia. Singaporean politics, as Sinha claims, is not racially antagonistic. Hence, the demolition of illegal Hindu temples in Singapore is seen as inevitable in making way for the country's development. Therefore, as Sinha notes, the reason why Singaporean Indian Hindus conformed and complied willingly with the demolition of these temples was that they did not perceive the demolitions as threats against their religious freedom by the government. For Malaysia, however, racial issues continue to be fundamental in Malaysian politics. As mentioned in the last section, scholars and Hindu leaders contended that the demolitions of these Hindu temples are proof of how the Malay Muslim-led government is discriminating against Malaysian Indian Hindus. In this respect, Penang is situated within this political setting. This political setting serves as the external context for establishing the political, social and religious institutions of a Hindu temple in Malaysia. Particularly across the three case studies, my analysis will demonstrate the connections between the political setting, the institutions of these three Hindu temples and the narratives by the Indian Hindu communities about the significance of their community temples. Their narratives that revolve around the importance of their community temples reflect their experiences with their political and social surroundings. Their experiences then shape how they conformed and complied with the demolition and relocation of their community temples.

Sinha (2005) also suggests that the internal context for a Hindu temple constitutes a complex network of exchange, reliance and support between the devotees, ritual objects, religious specialists and the temple. With each of these elements functioning efficiently, a Hindu temple becomes not only an abode for Hindu deities and a place of worship but also a social institution that defines a social hierarchy among the Hindu communities that the temple served. Many studies have shown the effectiveness of Hindu temples as social institutions, especially for the diasporic Indian Hindu communities. For example, literature has also shown that Hindu temples built by diasporic Hindus functioned as a tangible emblem that distinguishes the diasporic Hindus from other foreigners (Knott 1987, 161; Younger 2010, 46). These temples were their visible communal symbols (Younger 2010, 243; Clothey 2006, 28) and visual identity (Bhana 1999, 301; Baumann 2001, 67; Kumar 
$2013,52)$. They provided concrete and tangible communal enclosures where the diasporic Hindus performed collective rituals (Younger 2010,37). Through collective rituals and traditional Hindu teachings, the diasporic Hindus were able to pass down their traditions, especially to those new generations of Indian Hindus born in foreign lands (Wilson and Becksvoort 2001,334). These religious activities enabled the diasporic Hindus to establish strong communal ties (Vertovec 2000,138), re-assert Hindu pride, and ease the identity crisis among young Hindus (Wilson and Becksvoort 2001,339). Temples also enabled the diasporic Hindus to mark their space and assert their presence in foreign lands (Kong 1993; Vertovec 2000). As I will demonstrate in each of the three case studies, the communal significance of these temples is prominent regardless of their shapes, forms and sizes. It is also within the temple that the Hindu community is able to share the homogeneity of its marginalised minority social conditions, and at the same time dependency on each other (Scott 1990, 135). This is reflected specifically in the first and second case studies. The first case study is an estate Hindu temple that is serving the estate Hindu community. The second case study is a temple for the council workers, The British government established this temple to cater for the Hindu labourers working at the port of Penang during the 19th century. To date, this temple still bears communal significance for the council workers and the Hindu community that is still residing in the area.

Besides, the previous literature has also indicated that the communal significance of a Hindu temple is inter-related with its political significance. For instance, during the colonial period, Willford $(2007,19)$ noted that the kanganies (estate supervisors) and the panchayats (village heads) had reinforced the caste hierarchy through rituals and ceremonies. Such social and political significance of the temples has been a legacy from the medieval period. During the period, Hindu temples were the central institutions that defined the social order and hierarchies of the kings (Mubayi 2005; Mukund 2005) As a platform in sustaining a king's authority; it was the king's duty to ensure that the construction of a Hindu temple conformed closely to religious requirements. It was believed that any mistakes in the construction process would cause ruin to the kingdom (Kramrisch and Burnier 1996, 8). Mubayi $(2005,44)$ also found historical records, which described the sacredness of Hindu temples that often include genealogy, myths and social 
commentaries associated with the king. These documents reflected how the temples functioned as the platform for political clientelism between the king and commoners (Appadurai 1981, 64). The royal exclusivity of temples changed during the $19^{\text {th }}$ century, especially in diaspora settings. With the migration of Indian Hindus, the construction of a Hindu temple was no longer limited to the king. Nevertheless, even though the royal exclusivity had changed, temples remained as an effective avenue for re-establishing the political and social hierarchies among the diasporic Hindu elites and leaders who built the temples on foreign lands. Rather than being perceived as a royal duty, they believed that temple building is an expression of piety and devotion, which would bring benefits to the whole diasporic Hindu community that the temple served (Michell 1977, 50). By building a temple for the community, Hindu leaders established and/or sustained their social positions as among the patrons of gods residing in the temple. This has further explained how the temples in the estates and plantations were effective for the kanganies and panchayats to sustain their higher positions among the Hindu labourers in Malaya.

Moving to the contemporary context, Hindu temples remain as the institutions that sustain the social power and influence of the management committees. As I will demonstrate in the three case studies, the management committee of these temples often has the decisionmaking power about matters relating to the temples. This includes the decision whether to comply with the government for demolishing and relocating their community temples. Each temple has a different mechanism to appoint members for the positions in the management committee. For example, in the case of the estate temple and the temple for the council workers, the existing members of the management committees appoint new members into the team. The appointment will be made if any existing members have retired, resigned or passed away. These members often have kinship ties. The sons of the existing members often assume vacant positions in the group, but not necessarily inheriting the positions of their fathers. As the management committee of the temples, they often have better socio-economic conditions or higher social positions among the local Hindu communites. For example, the chairman for the estate temple also assumed the position as the village head for the Hindu community. Members of the management 
committee of the temple for the council workers share a similar upper middle-class background.

As the decision makers regarding matters relating to the temple, the management committee member often assumed higher social positions among members of the local Hindu community. Hence, this is one of the important reasons that the management committee want to ensure that the temples continue to exist as places of worships for the local Hindus. In the three case studies, I demonstrate how these temples are important as platforms for the management committees to hold rituals, festivals and celebrations. Through these events, I have observed how the management committee have reinforced patronage relations with the local Hindu communities. Through rituals, they have reiterated their reponsibilities as the patrons of the Goddesses, to seek conformity from the local Hindu communities with their decision to comply with the government. In Chapter Four, I have also demonstrated one of the possible consequences when the management committee fail to obtain agreement from the local estate Hindu community for their decision to comply with the government. The tensions between the management committee and the local estate Hindu community had undermined the functions of the temple as the religious and communal centre.

Literature about Hindu temples as social and political institutions also suggests the communal exclusivity of each temple for a specific Indian Hindu community. Such communal significance further suggests that a Hindu temple has an important function to segregate a particular Hindu community from others. For instance, Winzeler $(2016,60)$ found that during the colonial period, every 'standard estate' often had more than one Hindu temple. These temples housed local deities such as Mariamman, Murugan and Muniandi and served different Hindu labourers from different places of origin. Based on the historical findings in Singapore, Clothey (2006) also found that Hindu temples were further divided among Hindus with different occupations. For example, Hindu temples for the Goddess Kaliamman could be found at the communal site of Hindus who worked in the cattle trade and caring for horses and bullocks, while temples for the Mariamman deity were constructed for the Hindu harbour workers (Clothey 2006, 60). Clothey (2006) found 
that caste distinctions were also reflected in the temple buildings for the same deity, the Goddess Mariamman. Therefore, the communal specificity of each Hindu temple is what makes a temple important for each community, regardless of its shape and size. My analysis of the three case studies will show that the communal specificity of each temple is a motivation for the management committees to protect the autonomous management control of their community temples. Such diversity among Indian Hindus also serves as an important context for the pragmatic and strategic approaches of conformity and compliance by the Indian Hindu communities in the three case studies. As their communities are small in number, their compliance and conformity are pragmatic, within their capabilities and without having to involve outsiders. Hence, the compliance approaches of the Indian Hindu communities also reflect how they protect their autonomous control of the temple.

The literature review in this section demonstrates the various political and social significance of Hindu temples. Subsequently, I have also suggested that this significance of Hindu temples not only shapes the diverse conformity and compliance approaches of the Indian Hindus in the three case studies. This significance is also motivation for the management committees to retain participation and devotions of the members of the Hindu communities especially after the demolition and relocation of the temples. Specifically, the management committees have to convince the government that their community temples as sacred places can be relocated. Hence, in the next section, I review the literature concerning the concept of 'sacred place'. I gauge how the Indian Hindu communities could make sense of the demolition and relocation of their community temples as sacred places. Their ability to accept the demolition and relocation suggests a contribution to the existing concept of a sacred place. Therefore, in the following section, I review the literature on a 'sacred place' as a means of identifying the knowledge gap.

\subsubsection{Hindu temples as sacred places}

The conformity and compliance by some of the Indian Hindus when their community temples were destroyed by the government invites the question of how some Hindus could accept the demolition of their community temples as sacred places. In this section, I review 
the scholarly literature to identify what constitutes the sacredness of a place, and what scholars believe are implications of the destruction of a sacred place. In what way the willingness of the management committee and the communities in Penang to have their community temples destroyed and relocated is also identified in this existing literature.

Based on the description in the Puranas and Upanishads, the sacredness of a Hindu temple is interweaved with the sacredness of the place where the temple is built. The sacredness of a place, also known as Tirtha is a place of pilgrimage towards the realisation of the supreme principles of knowledge (Bramavidya) that bring final release (moksa). It is the passage for one to cross over to the Centre (Nirvana). Ideally, Tirtha is situated by river banks, lakes and seashores, where the presence of water is essential (Kramrisch and Burnier 1996, 3-5). Hence, for the Indian Hindu communities of the three case studies to willingly accept the government's proposal in demolishing their community temples and relocating the statues of the deities in the temples to temporary buildings are unprecedented in traditional Hinduism. Moreover, after the Tirtha is identified, a qualified Brahman priest would purify the Tirtha, and a team of qualified architects is selected to build the temple. Each detail of the temple building is inscribed with religious significance.

Based on the significance placed on the structure of a Hindu temple, the destruction of a Hindu temple structure is associated with the destruction of a sacred place. It is in the temple that a devotee feels a sense of certainty that all human needs may be answered, a place where they can seek guidance about their problems and protection from all threats and danger (Turner 1979, 19-20). It is also the ultimate centre for human affairs. Turner $(1979,21)$ further explained that a Hindu temple is a place where the relationship between god and people is established through consecration and rituals of possession. This divine nature of a Hindu temple reflects the importance of its sacredness. According to these Hindu Scriptures, devotees are meant to approach a temple as a place for pilgrimage, a house for the god to dwell in and a place that connects heaven and earth. Nevertheless, with the demolition and relocation of the temples in the three case studies, it is apparent that management committees and the Hindu communities have to make sense of such dramatic changes to their community temples. Smith $(1992,7)$ further argues that for a 
place to be 'sacred', its sacredness is imparted by believers. It is their narratives of the place with their generational memories and ancestral significance that make a place sacred. Hence, the 'sacredness' of a place is often narrated by individuals based on her/his complex experience. As the narrative of the sacred is intertwined with experience, it is flexible and even intendedly 'slippery' (Kinnard 2014, 178). It is one of the focuses of this study, to examine how the affected Hindu communities narrate the sacredness of their community temples. Their narratives project how they could still believe that their community temples are sacred places after the demolition and relocation.

Hence, I suggest that the ways that the Hindu communities have made sense of the demolition and relocation indicate that the sacredness of these temples is a fluid and human construction (Prufer 2015). Their ways of making sense of the demolition and relocation while still maintaining the sacredness of the places are diverse. As I will demonstrate in the three case studies, their religious beliefs and attachment to these temples not only shape the diverse ways that the Hindu communities make sense of the demolition and relocation. Rather, their narratives of the sacredness of these buildings also project their implicit agenda for ensuring that the government does not destroy their community temples. I agree with Mazumdar and Mazumdar (1993) that the sacredness of a place is the interconnectedness of space between religious belief, identity and attachment. Such interconnectedness is created and maintained by rituals. I further suggest that such interconnectedness also has also projected the importance of power relations between the management committee and members of the local Hindu community for each of the three temples in the case studies. I will further investigate the dynamics of power relations between these two parties. How do their relationships shape the sacredness of these Hindu temples?

Furthermore, based on the scholarly literature, threats against a sacred place often invite dramatic reactions from the devotees. Friedland and Hecht (1991) argue that the catalyst for the formation of a sacred place is often conflicting between different communities. This is because conflict could galvanise their deepest emotions and attachments, which are expressed through narratives. Narratives comprising agents, actions, scene, goals and 
instruments create a sacred place. Nonetheless, these different constitutions of narratives demonstrate diversity in the significance of a sacred place. The diversity of the significance has been reflected profoundly in the historical and contemporary conflicts of the communities involved (Friedland and Hecht 1991, 27). It would also appear plausible that the worshippers may possess diverse beliefs in the significance of a Hindu temple as a sacred place. Nonetheless, I argue that the diverse beliefs of the worshippers further suggest that they might accept the relocation and re-establishment of their community temples despite the deepest emotions and attachments that the devotees have for the place, as demonstrated by the Hindu communities of the three case studies.

According to Mol $(1976,13)$, is further motivating the process of 'sacralisation' through myths and religious symbolism. Mol $(1976,6)$ defines 'sacralisation' as the process of becoming or making sacred. This process constitutes four mechanisms: Commitment, objectification, myths and ritual. According to Mol $(1976,13)$, myths sublimate the conflicts and reinforce personal and social identity. Mol (1976) contends that sacralisation is an inevitable process in safeguarding an identity when it is under threat from the changing symbolic systems. He argues that "commitment anchors a system of meaning in the emotions and given time, develops into awe which wraps the system in 'don't touch' sentiments" (12). However, he also added that the process of sacralisation is often driven by the intent to "protect identity, a system of meaning, or a definition of reality, and modifies, obstructs, or (if necessary) legitimates changes" (Mol 1976, 6). It is worth noting that the performance of acquiescence to the hegemony of the government by the Hindu communities in the three case studies entails the demolition of their community temples. To overcome the sense of loss from the structure of their community temples, the narratives from the Hindu communities often reveal how they desacralise the former location and then sacralise the new location to make sense of the demolition and relocation. The willingness of the Hindu communities for the government to demolish their community temple is contradictory to the notion of safeguarding the existence of these temples. 
The activities of sacralisation by the three groups of the Indian Hindu communities in Penang also suggest a shift of perspective to the notion that a sacred value cannot be challenged or traded off with a mundane value. Scholars such as Atran and Axelrod (2008) have studied the possibility of secular encroachment on the sacred value of an object. According to them, encroachment is possible through reframing the sacred value of an object to make it possible for the object to be a trade-off with a mundane object. Atran and Axelrod $(2008,226)$ define the sacred value as a moral imperative that stems from religion as well as from individual morality, fairness, reciprocity and collective identity. However, they argue that if a sacred value is enforced to the point of representing the identity of a community or individual, any suggestion of a trade-off for this sacred value will be perceived as an insult and will instigate aggressive actions from the community. The communities of the three case studies in Penang have not reacted aggressively against the government for the demolition of their community temples. Based on these arguments, it is apparent that the conformity and compliance of the communities in having their temples demolished and relocated suggest that these Hindu temples were less 'sacred'. However, as I will demonstrate in the analysis, each member of the community believed strongly in the sacredness of their community temples. These previous studies have been inadequate in explaining the willingness of the Indian Hindus to have their temples demolished and relocated while still believing in the sacredness of the temple. Instead, systematic patterns of response are evident among temple management and among worshipers that may be predicted by the situational demands that a specific temple was facing.

\subsection{Methodology}

Based on the review of the literature, it is apparent that the reactions of the three groups of Indian Hindus in Penang contribute to existing scholarly debates that range from their pragmatic reactions to their narratives about the significance of their Hindu temples as sacred places. In this section, I present the methodology for this study. This includes my selection of three Hindu temples in Penang and the inclusion criteria for the participants of the interviews. Then, I explain the fieldwork process and the limitations. After that, I explain how I analysed, managed and reported on the data in this thesis. Finally, I explain the ethical considerations throughout the research process. 
I have employed a qualitative approach to this research, to problematise the conformist behaviour of the participants. This approach enables me to explore and analyse what are the compliance approaches and attitudes of the management committee? How are their approaches and attitudes being received and responded to by the local Hindu communities and the government that demolished and relocated these temples? Why do they perceive their compliance and conformity as necessary? A qualitative approach gives more prominence to voices from the participants as they narrate their experiences and their reasonings (Brockington and Sullivan 2003, 59). Their narrations reveal their perceptions, thoughts, 'facts and contextualised materials (Brockington and Sullivan 2003, 65), which are important for analysing their subtle and indirect political acts of safeguarding their community temples. To obtain data, I have employed in-depth interviews with a list of questions as a guideline. This guideline interview questionnaire is attached in Appendix A. I have also attended the events held in the temples to observe the rituals and interactions among the worshippers in these temples.

The three case studies in this thesis comprise three demolished Hindu temples. During the fieldwork, the deities from the three temples were temporarily housed in structures built for that purpose. Selection of these temples was based on two main reasons. The first was to achieve my research objective of comparing the reactions of the Indian Hindus in different contexts of demolition. Hence, the state government of Penang demolished two out of the three temples, while the Department of Public Works (JKR) demolished one temple. These temples were situated on an estate, a suburb, and in the capital city of Penang, respectively. The temples were located on land belonging to the authorities. Secondly, selection of these temples was decided mainly for pragmatic reasons. After approaching a few temples, the management committees of these temples agreed to the interviews. I obtained their signed consent, as part of the human ethics requirements. Besides the three temples as case studies, selection of the participants was based on two inclusion criteria. The first criterion was a long-term relationship of the participants with the temple. The second criterion was that the participants must have experienced personal loss due to the demolition and relocation of their temples. The participants comprised 
members of the management committees, temple priests, and worshippers who visited the temples, often for many years. Although the qualifications required to be members of the management committee are varied for different temples, they share some general criteria. For example, the founders or the descendants of the founders of the temple have inherited the positions from family members, or have been nominated by other members to join the team. The criterion of the long-term relationship with the temple is based on the selfascribed identification of the participants. The interviews often started with the participants describing the historical background of the temple. Their responses often revolved around their childhood memories of the temple, as their grandparents and/or parents used to bring them to the temple. This inclusion criterion is important as the Hindu communities involved were unable to produce any formal documentation to justify claims that the temples were a century old. Their generational memories associated with the temples became their only defence for justifying the importance of their temples, and, hence, why they should not be demolished.

The management committees of the temples were at the forefront of negotiations over the government's proposal to demolish and relocate the community temples. As I will demonstrate in subsequent chapters, as members of the management committees, they were the decision makers for matters regarding the temple. Their decisions were an important contributing factor to the reactions of the worshippers. The worshippers' agreements with the decision of the management committees to demolish or relocate the community temple affect the functions of the temporary temples as religious and social institutions. The priests, who spent the most time in these temples, gave important accounts of the changing meaning and functions of these temples. The roles of these three groups of participants enabled me to place the findings in the right context for this study. Based on these two criteria, I have interviewed twenty-one participants in three case studies. The number of participants is by no means representative of the possible responses of other Indian Hindu communities whose temples are demolished and relocated in Penang or Malaysia. In fact, as I will demonstrate in the three case studies, each Indian Hindu community has distinctive political and social realities that are shaped by their relationships with the DAP-led state government, the BN-led federal government and 
members of the local Hindu communities. Nonetheless, for each case study, the interview data I have collected reached a saturation point when accounts from the participants in the respective case studies showed no new insights about their encounters (Patton 1999, 1197; Ezzy 2002, 75). As I will show across the three case studies in subsequent chapters, the saturation of the responses is reflected in their similar attitudes of conformity, compliance and cooperation toward proposals to demolish and relocate their community temples.

I took approximately six months for the fieldwork (September 2015-March 2016), with roughly six weeks spent on each of the temples. The ethnographic data for this study is derived from in-depth interviews and field observations. The interviews were conducted with guideline questions. The questions revolved around four main themes - the background of the temple, the demolition and relocation process, their feelings and thoughts about the demolition and relocation of their community temple, and their narratives about the sacredness of the temple and the deities. The interview questions are attached in Appendix. The interviews were conducted in both English and Bahasa Malaysia, depending on the language proficiency of the participants. Each interview took approximately forty-five minutes. After the interviews, a summary of the transcripts was sent to the participants for cross-checking. All the interviews were transcribed verbatim. I then used the NVIVO 11 software to code the interviews based on four general themes the background of each temple, the process of demolition and relocation of the temples, the reactions and actions of the participants, and their narratives about the sakti of the deities and the temples.

The initial data that I have obtained from the formal interviews with the participants enabled me to use grounded theory to analyse the data. The conversations enabled me to establish a rapport with the participants. This rapport enabled my subsequent visits and for me to engage in a series of informal conversations. The informal conversations were as important as the formal ones. They enabled me to explore the context further and to construct the arguments about their pragmatic reactions to the demolition and relocation of their community temples. Due to their increasing familiarity with me and the absence of 
voice recorders, I was even welcomed to join in group conversations. From the informal conversations, I have also gauged their sentiments about the religious and communal significance of the temples. Hence, the rapport and subsequent visits enabled me to analyse the data based on the different context of each of the case studies.

Furthermore, in-depth interviews have enabled me to document and present voices derived directly from the participants. This is important as I am aware of my origin as a Penangite and position as the researcher in the field. As Brockington and Sullivan (2003, 66) highlighted, it is a tendency that the ethnographer adopts an authoritative viewpoint over a 'society' and constructs its norms and rules. As a Penangites myself, I am cautious of my own viewpoints about Malaysian politics and Indian Hindu communities that may influence my analysis of the responses of the participants. Hence, to validate my arguments and analysis, I have included verbatim interview quotations in my analysis of the case studies to accentuate their voices not only as my data analysis but also to confirm my analysis. These quotations are in two main languages - Bahasa and English. Most of the participants felt more comfortable conversing in Bahasa with me as it is the lingua franca in Malaysia, Their Bahasa is in a colloquial form. Although I have transcribed the interviews verbatim, I have tried to spell out the words they used, which might still vary from the original spelling of the Bahasa Baku (formal spelling and pronunciation in Bahasa). Furthermore, in colloquial Bahasa, the participants did not always use sentence structures that were correct in formal language terms. Most of the sentences were broken (with a mixture of Hokkien and English), incomplete and contained words not included in the formal Bahasa dictionary. To stay true to the verbatim of the transcripts, I have included these quotations in the chapters, but in the form of footnotes. To ease reading and comprehension, I have translated these colloquial Bahasa quotations in proper English form when included in the discussion of the chapter. As for those who chose to converse in English in the interviews, necessary corrections have been made to ensure clear understanding and reading. After each session of the interview, I made a summary of the interview (according to the language that was used in the interview) for the participants, to ensure the correct understanding of the data in our interviews. As not all the participants 
are literate in formal Bahasa, a brief session of discussion was often held when I handed over the interview summary.

Besides the interviews, I attended the daily worship and special rituals that were performed in the temples. I observed activities in the temples, which included their worship and interactions with priests and members of the committee. I engaged in informal interviews with worshippers and members of the committee when the opportunity arose. I also took photos of these events, some of which are depicted in subsequent chapters on the three case studies. The data obtained are useful for the analysis in Chapter Five and Chapter Six. I analyse the case studies regarding the functions of the festivals and ceremonies based on informal conversations with the worshippers and observations. For instance, Chapter Five includes conversations with two members of the family that have been managing the temple since their late mother discovered it. I also interviewed four local worshippers about the sacredness of the Goddess during the ten-day Navratri festival. The family also hosted the annual Open House celebrations during Deepavali. I observed and recorded the speeches of the politicians who participated in the festival while holding conversations with four adult guests at a table during the event. In Chapter Six, I demonstrate the conversation with the worshippers who participated in the Balathanam ceremony. The chapter gives an account of a conversation with a member of the management committee, who explained the ceremony that was taking place, as well as conversations with the worshippers during the relocation concerning the essence and statues of the deities. These conversations were about the sakti of the Goddess, and the process of the demolition and relocation of the temple.

\subsection{Thesis limitations}

I have identified four limitations to this thesis. In this section, I address these limitations, their implications for the findings. I also discuss ways of overcoming them.

One of the limitations was mainly due to the implications of the demolition and relocation of these community temples. As I will demonstrate across the three case studies, the demolition and relocation have threatened the functions of the religious and communal 
significances of these temples. The loss of function experienced by these temples was reflected by the desertion of their local worshippers. As a way of overcoming this limitation, the participants were identified through a snowballing process. While the method had been useful, it was not the only technique used, as such a method of participant selection would hamper the process of collecting representative data for the different context and situation in each of the case studies. Hence, besides the snowballing method, I also made several visits to the temple as a way of engaging with the other members of the community.

My research interest in the issue of Hindu temple demolition in Penang stems from my prior research in 2012-2013. With funding from the Penang Hindu Endowment Board (PHEB) and the DAP-led state government, I conducted a mapping survey on all of the Hindu temples in Penang. The mapping survey was to fill the gaps of knowledge concerning the locations and registration status of these Hindu temples. For the survey, I managed to find a total of 226 Hindu temples, which included proper Hindu temples, roadside shrines, temples in estates and family temples that receive visits from other Hindus. My prior experience with Indians in Penang proved to be both of an advantage and a disadvantage in this PhD project. The first advantage was that it provided the framework of the study, and with my understanding of the Indian Hindus and their relations with their community temples as well as through the data gathered from the mapping survey, I could identify a few Hindu temples that were illegally situated, which could be potential sites for this project.

However, my prior engagement with the communities has deterred me from crossing communal boundaries. In fact, while the communities were under a prevailing sense of threat and had the urge to protect their temples, my previous experience when working for the state government had different implications about how these interview participants answered the questions. This was in agreement with the findings of Ezzy $(2002,67)$ that the participants' perception of an outsider influenced the way they portrayed themselves during interviews. Furthermore, Scheyvens et al. $(2003,177)$ have highlighted that minority ethnic groups would have more political awareness, and may be wary of outside 
researchers. This has been a concern for this fieldwork process. For instance, some of the participants still identified me as the Chinese woman who used to work as a researcher for the PHEB and state government. Due to the politics of the issue, my former reputation as a researcher funded by the PHEB and state government have influenced the behaviours, rhetoric and responses to my interviews. For those participants who could not shake off their perceptions of me as a state government officer, their answers to the questions reflected their intentions to a plea for help from the state government as a means of indicating their discontentment with the relocation, and/or to perform their conformity to the state government. To overcome these limitations, I managed to build a rapport with the participants by making frequent visits to the temples so that my presence would become a familiar sight to the worshippers. During my visits, I engaged in informal conversations with some of the worshippers as a way of gaining their trust. Being introduced by the chairperson or members of the management committee also helped in establishing a bond with prospective participants. However, despite my efforts to become familiar with the participants, some of them were still cautious in opening up to me.

Thirdly, my ethnic identity and gender also served as an asset and a detriment during the course of study. Being a Chinese and an outsider, I am neither part of the existing friction between the different Indian Hindu communities nor between the Hindu and Malay communities. Hence, the participants were more willing to answering questions about the demolition and relocation of their community temples. This included how and why they agreed to the proposals of the government. Nevertheless, my lack of proficiency in the Tamil language was also one of the obstacles I faced in this study. This limitation influenced my selection process when deciding on the Hindu temples and worshippers. To overcome this limitation, I had chosen temples whose management committee members were conversant in either Bahasa Malaysia or English. Furthermore, my previous research with Indian communities has raised my awareness of the significance of Hindu temples as religious, social and political institutions. Hence, it was necessary to obtain permission from the chairperson before a temple could be selected as a case study. A temple where the chairperson appeared to be comfortable to be interviewed would indirectly make the other participants feel more at ease in sharing their opinions. This, however, has limited the 
selection of Hindu temples for this study. It is important to note that the findings from the three case studies in this thesis cannot be generalised for all cases of demolished and relocated Hindu temples in Penang. My exploration and analysis have consistently shown that each of the case studies is contextually specific. The selection of the three case studies was also determined by the consent given by the chairperson of each of the temples. To obtain the consent, I had to explain to the chairperson about the purpose of my research and the set of interview questions prepared for potential interviewees.

A letter of introduction to the study and an explanation of the research were presented to the person/s involved. Assurance in maintaining the confidentiality of the participants in the study was also given. Before beginning the interviews, the participants were briefed on their rights to refusing questions that they felt uncomfortable with. Permission to record the interviews was also sought from the participants. The participants were informed that a summary of the interviews would be given to them and was made aware of the fact that they could choose to withdraw from the study before the end of March 2016.

Fourthly, indeed, my findings and analysis have consistently reflected the importance of the political context as a factor in determining the effectiveness of conformist attitudes of the participants. Although my data have not included interviews with the authorities, it does not hinder my analysis of the infrapolitics of the local Hindu communities in the three case studies. I have been following the public transcripts of the politicians reported by the news media, both online and in print regarding the issue of Hindu temples demolition from 2006 until 2018.To maintain the confidentiality of the participants, pseudonyms have been used in this research project. The names of the Goddesses housed in these temples have also been used to replace the actual names of the temples. In Chapter Four, the name of the estate has been omitted as a means of protecting the confidentiality of the participants and the temple involved. The Human Ethics Committee of the Victoria University of the Wellington has approved these confidentiality procedures. 


\subsection{Organisation of chapters}

In Chapter Two, I review the secondary resources to gauge the context of the contemporary issue of Hindu temples demolition by the government. This context constitutes the historical, as well as the contemporary political and social circumstances of Indian Hindus. I identify the way the participants across the three case studies developed a lexicon for a series of key terms that they often used to justify their conformity and narrate the sacredness of their community temples. I have also suggested the importance of critical analysis of the subservience displayed by communities, particularly those from lower income groups, as a way of projecting their political and social realities. This issue, however, has been continuously overlooked by the existing discourses on Malaysian Indian Hindus. In Chapter Three, the inadequacies of current discourses that revolve around the issues are discussed. The generalisations of these discourses that fixate on the Malay Muslim-led ruling government as the main perpetrator were identified with a literature review on the political and social context of Penang as the research site. Chapters Four, Five and Six contain the analyses and discussions of the three case studies. I conclude this thesis in Chapter Seven, by summarising the acts of compliance and conformity by the Indian Hindus of the three case studies that were deemed as pragmatic ploys for hidden agendas. I also discuss the contribution of this thesis in filling the existing scholarly gaps about the pragmatic reactions of the Indian Hindus that were involved in the three case studies and the shift in the meaning and functions of the demolished and relocated Hindu temples in Penang. It is also in this chapter that I propose a shift of perspective in the future studies of Malaysian Indian Hindus, especially in gauging the political realities of Malaysian Indian Hindu minorities. Lastly, importance should be placed on the need to further explore and examine the apparent 'docility' and submissiveness of the Indian Hindus as their pragmatic reactions to the prevailing political control in Malaysia. 



\section{The politics of the issue of Hindu temple demolition}

This chapter provides an insight into the Malaysian political and social contexts that influence the acts of conformity and compliance among Indian Hindus in the three case studies of Penang. As discussed in the last chapter, minorities and subordinate groups often prefer pragmatic strategies of compliance and conformity to achieve their agenda. In this chapter, I review the literature that describes Malaysian Indian Hindus as minorities. Specifically, I examine how Indian Hindu minorities, especially those from the lower classes are often described as submissive and powerless when they face the dominance of the government. Hence, the objective of this chapter is two-fold. First, I review previous studies about the minority status of Malaysian Indian Hindu communities with the backdrop of the political and social contexts in Malaysia. I also explore the previous incidents when Indian Hindu communities had employed subtle and indirect approaches while they engaged with the hegemony of the government. Second, I examine what the political and social functions of Hindu temples are for these Indian Hindu minorities. Besides, as places for worship, what other significance do Hindu temples in the multiracial and multicultural Malaysian society that is governed by Malay Muslim-led government have?

I divide this chapter into two parts. The focus for the first part is to review the literature about Indian Hindu communities as powerless minorities in Malaysia. I begin this chapter by tracing the notion of the submissive and docile nature of Indian Hindus back to the colonial period. I explore the historical analyses about the Indian migrants that came to Malaya and the functions of Hindu temples for these Hindu migrants during the 19th century. I also investigate what are the possible explanations that the remaining Hindu temples today are still unregistered, undocumented and situated on lands that belong to others. Then, I review the literature about the diversity and fragmentation among Indian Hindu communities that had decided to remain in Malaysia after Independence. 
Specifically, I examine how the Indian Hindu communities remain as minorities, even though they are the third largest racial group in Malaysian society. I also review the literature about the functions of Hindu temples in maintaining segregations among the Hindu communities. I identify how the significance of the Hindu temples for the diasporic Indian Hindus in Malaysia changed in tandem with the changing social and political landscapes in Malaysia. This includes the effects of the increasing dominance of the Malayled government and the country's subsequent experience of the Islamisation movement. Subsequently, I explore how the previous literature has consistently claimed that the Indian Hindu communities, especially those from the lower class and caste background are marginalised and discriminated by the Malaysian government. More importantly, I demonstrate how scholars have argued that these lower class and caste Indian Hindus are powerless and hence remain submissive to the hegemony of the Malay Muslim-led government. I examine how the Hindu temples that were established for the Indian labourers during the 19th century became increasingly vulnerable as a result of the encroachment of development policies of the Malay Muslim-led government.

In the second part of this chapter, I explore the contemporary context for the issue of Hindu temples demolition by the Malaysian government. I investigate the political rhetoric by scholars, Hindu leaders and politicians that have accused the Malay Muslim-led government of discriminating against the Indian Hindu minorities. I investigate how such rhetoric, which is rendering the Indian Hindu communities as powerless minorities, are paradoxically useful to the Indian Hindus in the three case studies. I begin this part of the literature review by investigating the campaign of by HINDRAF against the Malaysian government for demolishing the Hindu temples that situated on the private and government land. Then, I examine the political context for the issue of Hindu temples demolition after the general election in 2008.

\subsection{Indian Hindus as powerless minorities in Malaysia}

I begin this section by reviewing the literature on the political and social context of Malaysian Indian Hindus. Particularly, I explore how previous literature describes the powerlessness of Malaysian Indian Hindus because of the persistent marginalisation and 
discrimination from the Malay Muslim-led government. My argument for this literature review is two-fold. Firstly, I argue that such persistent arguments have rendered it impossible for Malaysian Indian Hindu communities to fend for themselves, under the given political and social surroundings. These on-going conventional arguments have silenced the voices and diverse political actions of the Indian Hindus as active Malaysian citizens. Secondly, in paradox, I argue that the pragmatic strategies of conformity and compliance with the Malaysian government would be particularly effective for Malaysian Indian Hindus, precisely because of the persistent arguments about their marginalised and discriminated positions. I begin by reviewing the literature from previous historical analyses about the influx of Indian communities to Malaya and the subsequent establishment of Hindu temples. Then, I examine the dynamic of Indian communities that remain in Malaysia after Independence. After that, I review previous studies that revolve around the political, religious and the persisting socio-economic marginalisation of the Indian communities as the country continues to develop.

\subsubsection{History of Indian Hindus and the illegality of Hindu temples in Malaysia}

From the outset, not only the previous literature, but also contemporary reports on the cases of the Hindu temples demolition often quoted the affected local Hindus as saying that their community temples were more than a century old. Tracing back to the previous century, Malaysia was known as Malaya and was colonised by the British. During this colonial period, Malaya was experiencing an influx of Indian labourers who work in the estates, plantations and railway-buildings. This period saw not only the mushrooming of Hindu temples in the country but also the perception of Indian communities as being docile and submissive to the hegemony of the government. Historical analyses have found the colonial period to be particularly significant in shaping the discourse about the marginality of Malaysian Indian Hindu communities to date. In this section, I explore previous studies to comprehend how the historical period of British colonialism formulated the arguments about Malaysian Indian Hindu communities being marginalised and powerless minorities. I also examine how the colonial period shaped the significance of the existing Hindu temples. How the notion about the Indian Hindu migrants by the colonial government remains significant to the Malaysian Indian Hindus in the contemporary context? How are the 
significances of Hindu temples changed over time in response to the racial based Malaysian politics?

The claims of temples being century-old by the local Hindus were often based upon inherited family memories of visiting the temples for generations. I met an Indian Hindu who is also the caretaker of a temple. He said, "This temple is old, more than a hundred years, more, you know. Before me, now I am already fifty years old. My father once told us, when we were still small, about seven years old. He said, 'when I first came here, the temple was already here.' ... This temple has been here for so long, how can it be removed? It cannot be removed." ${ }^{1}$ Although this temple had not been included in this thesis, it is situated on land that belonged to a private estate company. As he rationalised, the temple is a century old and therefore, should not be destroyed. The claim of the temple being a century old is consistent with the history that touches on the arrival of Indian Hindu labourers to Malaya during the colonial period in the century.

Despite claims of being a century-old, many of these Hindu temples were unregistered and had been situated on lands that belong to others. Hence, these Hindu temples had been facing threats of demolition by the landowners when the land changed hands over the years. Another participant summed up the threats of the demolition of his community temple, "[I am] the second generation [to take care of this temple]. [I inherited this caretaker position] from my father. My children also come to this temple... This temple, as far as I know, is more than a century old. It has served three to four generations of Hindu community here. This temple used to be in an estate. That estate belonged to a private company. So, the land does not belong to this temple. Now, a developer has come and wanted to develop the land of the estate."2 Eventually, the developer requested the DAP-led

\footnotetext{
1 Translated from: ...tokong ini sudah lama. Seratus tahun lebih, LEBIH tau. Sebelum saya, sekarang saya sudah 50 saya punya umur. Saya punya bapa dulu cakap, masa kita kecil, umur 7 dulu dia cakap "saya mari sana, mari sini sudah tau tokong itu sudah ada... Saya cakap, ini tokong sudah duduk lama sini. Ini mana boleh keluar punya. Ini tokong tak boleh keluar punya.

2 Translated from: ...Keturunan yang kedua. From my father. Anak saya pun ada... Kuil ini setahu saya lebih seratus tahun lah. Sudah 3-4 keturunan. Kuil yang terletak dalam Simpang Estate itu, estates itu milk swasta, tapak kuil bukan milk kuil lah, masa tu. Sekarang mai pemaju.
} 
state government to intervene and negotiation was made with the management committee to relocate the temple.

The two participants' claims of their community Hindu temples being more than a century old have accentuated two fundamental points of importance for the conformity and compliance of the Indian Hindu communities to be effective, pragmatic strategies. Firstly, these claims highlight the history of the influx of Indian migrants to Malaya during the 19th century. About seventy per cent of these migrants were indentured labourers working for the European planters. ${ }^{3}$ About eighty per cent of these Indian migrants were Hindus, while the remainders were Muslims, Christians and Sikhs (Sandhu 1969, 167). According to Sandhu (1969), one of the main driving forces for the influx of Indian migrants was the encouragement and preference of the European planters in Malaya to recruit them. Particularly, "the untouchable or low caste Madrasi, were considered the most satisfactory type of labourers" (56). These labourers were not ambitious compared to the Northen Indians and the Chinese migrants. These Indian labourers were also amenable to low pay and the harsh working environment in the estates and plantations. They were also wellknown among the British colonial government as docile and well-behaved (57), The second important driving force is the poverty and destitution that these low caste Indian communities were suffering back home (67). This historical analysis has been adopted by many scholars to support their arguments that these labourers were powerless and submissive to the colonial control (Manickam 2009; Belle 2015). Especially with evidence of coercion in recruitment and reports about abuse of Indian labourers by the European planters in the estates and plantation (Arasaratnam 1979; Chanderbali 2008), these labourers were further perceived to be powerless to fend for themselves.

\footnotetext{
${ }^{3}$ The other over thirty percent of non-labouring Indian immigrants included were mainly technical, professional and business migrants (Belle 2008a, 456). The Nattukottai Chettiars were the ones who thrived best. They monopolised the moneylending business and banking activities in Malaysia (Netto 1961, 53). They also owned rubber estates and properties. Their economic and financial achievements were reflected in the setting up of their own chambers of commerce in different places in Peninsula Malaya. Other Indians included the Ceylonese Tamils, Malayalis, North Indians and Sikhs, as well as South Indian Muslims. Netto $(1961,53)$ notes that the Gujaratis, Sindhis and Sikhs went into the import-export business. South Indian Muslims were mainly shop-keepers, general merchants, and money-changers, while others were skilled and professional workers.
} 
Secondly, the claims by the two participants have raised the question of why despite the century-old legacy of their community temples, these buildings have ended up becoming illegaly situated on others' land? This is because, while there were many Indian labourers who came to Malaya, many of them were also sent home after they had fulfilled their twoyear indentured labour contract(Netto 1961, 22). According to Sandhu $(1969,158)$, approximately sixty per cent of the immigrants chose to go home between 1824 and 1924 and between 1925 and 1957, more than eighty per cent of the total Indian immigrants who came to Malaya left for home (Sandhu 1969,158). Due to the high traffic of Indian immigrants moving in and out of Malaya, they had been popularly perceived as temporary residents by both the Malayan and British governments. ${ }^{4}$ Jain (1993) noted that in the Annual Report of Emigration from Madras, 1900-01, over the 10-year period, 82 per cent of the emigrants came back to their home. He also noted from the recent estimation that during the period of 1860 to 1957, about four millions of emigrants left India to Malaya, and about 70 per cent of this number left Malaya over the same period (Jain 1993, 2367). As many of these labourers were perceived as temporary residents by the governments, the British did not see the need for an institutionalised process to document the establishment of these Hindu temples (Kaur 2012). Hence, those temples were meant to be temporary buildings (Lal 2006). The indentured Indian Hindu labourers also had no resources to request the British planters to give formal entitlement to the land the temporary temples were situated on. As a result, most of these temples have remained undocumented and unregistered. In spite of just staying in Malaysia for a short period, these temples have continued to serve the Hindu labourers throughout the years.

It is evident from the previous historical literature that the British apparently still allowed the Indian migrants to build temples in the estates and plantations, even though most of them were temporary residents. However, such willingness of the European planters appears to contradict historical findings that show most of the Indian labourers were discriminated against in the workplace throughout their indentured contracts. Sandhu

\footnotetext{
${ }^{4}$ Even after Malaya obtained independence and during the process forming the Malayan government, their reputation as temporary residents had become one of the main reasons for the Malayan government's intention to marginalise them from political representation (Sandhu 1969, 172).
} 
$(1969,233)$ explained, the old Tamil saying "kovil illa uril kuti irrukka vendam" (do not live in a town where there is no temple), appears to have been particularly observed by the Hindus (Sandhu 2010, 233). Within the realm of the temple, the labourers could feel at home and overcome the tedium of their labour (Arasaratnam 1979, 66-7; Khoo 2009, 23 \& 5; Sandhu 1969, 233). The European planters were aware that these temples could help the Hindu labourers to establish the sense of locality through worshipping of their village deities (Prorok 2015, 267). In fact, these European planters also realised that they could use such significance of these temples to encourage the influx of more Indian labourers to work in Malaya (Arasaratnam 1993; Kent 2005, 30; Sinha 2011, 84). As a result, the numbers of Hindu temples increased parallel to the increasing number of Indian Hindu migrants to Malaya. Most of these temples were established in estates, plantations and by the railroads. Hence, the planters had allowed the indentured Indian Hindu labourers to build Hindu temples for their religious needs.

However, these explanations appeared to contradict with the notion of the discriminative working environment that the Indian labourers were facing in the estates and plantation. Pillai $(2007,11)$ could be right that the temples in the estates were particularly useful as "the seat of their cultural and religious link" for the Indian labourers. On the surface, this indicates that the labourers had autonomy regarding matters about their rituals and ceremonies in the temples. Nevertheless, beneath the surface, the European planters had also appointed kanganies (supervisors in the estates) and the panchayats (head of the village) to manage these temples in the estates, plantations and by the railroads. The kanganies and panchayats were Indian and Ceylonese who were expected to go back to their home countries once they had fulfilled their labour contract. They were keen to observe the laws of purity and pollution (Willford 2007). With the combined management of the Indian and Ceylonese panchayats and kanganies, temples allowed the British to have the active consent of labourers to be subordinates of their employers and estate supervisors and managers (Willford 2007, 18; Arasaratnam 1993, 206; Jain 1984, 169-70; Ramanathan 1995, 89). 
Pillai's arguments have indicated a breach in the existing notion that the Indian labourers were meek, docile and submissive to their harsh working environment in the estates and plantations. Furthermore, as indicated from the previous studies, the need for the European planters to contain the Indian labourers in the estates and plantations further reflects the possible reoccurring issues of insubordination that they had with these labourers. In fact, Pillai (2007) found records of numerous incidents of "insubordination of labourers"(13) due to the intrusions by their employers into their cultural and religious boundaries. ${ }^{5}$ Ramasamy (1992) also found similar evidence that few Indian labourers had joined forces with the Chinese labourers to protest against the European planters to demand more wages and better living conditions in the estates. However, he also argued that the numbers of the Indian protestors were small and insignificant. Nevertheless, despite such scant literature, they remain as important evidence that the Indian migrants were not docile and powerless, but were responding to their harsh surroundings. Although these historical analyses have shown the insubordination of the Indian migrants, such arguments remain scant.

The historical analyses in this section serve as important foundations for many contemporary arguments that revolve around the persistent marginalisation and discrimination against the Indian communities and Hindu temples in Malaya. These studies have shown that the formulation of the notion that Indian Hindus tended to be submissive and docile to the hegemony of the government. It is noteworthy that studies about how the Indian communities reacted to their discriminative environment remain scant. Due to the historical records of submissiveness and docility of Indian migrants, the pragmatic compliance and conformity as demonstrated by the Indian Hindu communities had become particularly effective in the political context of Penang. This is because, as Scott $(1990,10)$ argues, “...those obliged by domination to put on a mask will eventually find that their faces have grown to fit that mask. The practice of subordination, in this case, produces, in time, its own legitimacy..." Hence, as I will show in the subsequent case studies, the participants

\footnotetext{
${ }^{5}$ As an example, Pillai $(2007,11)$ cites an incident from the Annual Report of the Agent of the Government of India in British Malaya 1930: "Ten labourers of Parit Perak estate were charged for rioting and assault on the Assistant Manager who, annoyed at the beat of drums, had interfered unnecessarily with a marriage celebration conducted on the estate..."
} 
often adopt the rhetoric of powerlessness and submissiveness, and sometimes even indicate that they were being discriminated against precisely because they are part of the Indian Hindu minorities in Penang. On the other hand, the literature also suggests the possibility that many Hindu temples that still stand today in Malaysia could have been established during the 19th century. Although the three Hindu temples of the case studies do not have formal records for their establishment, the claims of century-old legacies have the possibility of being true. As I will discuss in the following chapters, such possibility had been sufficient for scholars and even Indian politicians to justify discrimination by the government against the religious history of the Indian Hindu minorities by demolishing the temples.

In the following sections, I review the literature to trace the continuation of the notion that the Indian communities were still submissive and docile to the dominance of the government even after Independence. Then, I also investigate how Hindu temples in Malaysia, especially those built for the Indian labourers become increasingly vulnerable to demolition as Malaysian politics, economy and society continue to develop.

\subsubsection{Dynamics and frictions among Malaysian Indian Hindu communities}

When Malaya gained Independence in 1957, Indians made up about 11 per cent of the total population and about 80 per cent of them were Hindus (Sandhu 1969, 175). The composition of Indian communities has remained similar to date. The latest Malaysian Population Census of 2010 recorded about 26 million Malaysian citizens. About seven per cent (1.8 million) of them is Hindu. About 86 per cent (1.6 million) of Hindus are Indian (Department of Statistic Malaysia 2010, 82). ${ }^{6}$ I argue that even though Indian communities are the third largest racial group in Malaysia, the Indian Hindus are still minorities in

\footnotetext{
${ }^{6}$ Based on the Malaysian population census in 2010, there are approximately 26 million Malaysian citizens living in the country, of which about sixty-one per cent of the total population (15.8 million) are Muslims; nineteen per cent (5.3 million) are Buddhists; nine per cent (2.4 million) are Christians; seven per cent (1.8 million) are Hindus; and three per cent ( 0.7 million) of other religious/non-religious backgrounds.

Additionally, about eighty-one per cent of the Buddhists are Chinese (5.2 million), and all the Malays (14.2 million) are Muslims. Approximately eighty-six per cent of HIndus (1.6 million) were Indians (Department of Statistic Malaysia 2010, 82). According to the report in the 2010 Malaysian Population Census, "population density of Malaysia stood at eighty-six persons per square kilometre in 2010 compared with seventy-one persons in $2000 "$.
} 
Malaysia. This is because Malaysian Indians are not homogenous racial groups. Hence, in this section, I review the literature to understand the frictions among Malaysian Indian communities. The literature review in this section is particularly important to understand the pragmatism of compliance and conformity of the Indian Hindu communities in the three case studies. Such pragmaticism is their key survival skill to fend for their own religious expressions.

The records of Malaysian population census from 1957 until 1991 continued to indicate Indian Hindu communities of different sub-categories namely, Tamil, Malayali, Telegu, Punjabi, Gujarati, Sindhi, Bengali etc. (Loh 2003, 224). Such categorisation has been discontinued since the Malaysian population census of the year 2000. Since then, all Indian Hindu sub-categories have been grouped under the heading, "Indian". By generalising Indian Hindu communities in the Malaysia population census, it is by no means indicated that the communities have been unified as a cohesive group, since the year 2000. On the contrary, the fragmentation of Indian Hindu communities is manifested through "endogamous marriage arrangements, occupational stratifications, caste organisations and different religious practices" (Kent 2005, 31; Mearns 1987).

Although Indian Hindu communities remain fragmented, the lines of fragmentation remain debatable. For instance, Willford $(2007,201-5)$ argues that the Indian Hindus have separated themselves based on their different classes. The upper and middle classes of Indian Hindus are generally those who receive higher education from overseas and come from professional families. The lower class are generally those from former estates and plantations. Some of them may have succeeded in lifting their socio-economic conditions through small businesses, such as sundry shops and restaurants. While the minority middle- and upper-class Indians reside mainly in the urban areas, Muzaffar $(1993,273)$ and Arasaratnam $(1993,191)$ note that the Indian labourers in the estates and plantations have continued to lead a subservient life and remained second-rated for generations. However, Kent $(2005,30)$ insists that the different class divisions among the Indian Hindus are correlated to their caste identity. Indeed, studies about caste frictions among Indian Hindus in Malaysia remain scant. However, Mearns (1987) argues that caste difference 
remains a significant factor for fragmentation among Indian Hindu communities. According to Lee and Rajoo $(1987,393)$, Malaysia had at least fifty-three registered caste associations. During the mid-1980s, Ramasamy (1984) discovered that more than half of his Indian respondents believed that caste consciousness was prevalent in Malaysia (25). Caste differences, prejudices and stereotypes are passed on from parents to their children (19). Regardless, the segregations between Malaysian Indian Hindus is a fundamental reason for the Indian Hindu communities in the three case studies to react pragmatically to the threats of demolition and relocation of their community temples. Scott $(2008,245)$ argues, often pragmatic compliance is a viable alternative, especially for the subordinate groups. Because of the prevailing fragmentations, Indian Hindu communities have remained the largest divided minority groups. As I will demonstrate in the three case studies, being minorities, to avoid protest has been more attractive for the Hindu communities than the risk of open confrontation (Scott 2008).

Moreover, it is precisely because of the fragmentation within Indian Hindus, most Hindu temples in Malaysia, regardless of shape and size are often important for different Hindu communities. From the outside, these temples often reflect class distinctions. For instance, Aveling $(1978,174)$ noted that there are four categories of Hindu temples in Penang: the 'cathedral' type, caste temples as well as the community and crisis worship temples. Within these temples, the caste distinctions prevail. According to her, the cathedral temple in Penang caters for the entire Hindu community, though the poor and untouchable Hindus tended to avoid worshipping in this temple, except during annual festivals. This is because the high-status temples are supported by high-caste Indian Hindus, such as Ceylonese Tamils and Malayalis (Kent 2005, 30). According to Lee and Rajoo $(1987,396)$, the cathedral-like Hindu temples in Kuala Lumpur and Petaling Jaya are controlled by Hindus from specific high castes and regional groups. In Penang, the cathedral-like Hindu temples are administered either by the Chettiar caste or by the Penang Hindu Endowment Board (PHEB). Although the Chettiar caste administers and finances these temples, these temples are not caste temples. The Chettiar community took over the administration of these temples during the last century. The management committee often hires Brahmin or Pandaram (caste of a priest serving non-Brahman castes) priests from India to perform 
Agamic rituals. According to Kent $(2005,30)$, the management committees of upper-status temples tended to avoid hosting blood sacrifice rituals and worshipping guardian deities, which they perceive as the preference of the lower-class Indian Hindu communities. Rather, they are more inclined to associate themselves with Sanskritic deities and often emphasise the presence of Brahmin priests during rituals and have a particular preference for a vegetarian diet. Besides the differences in rituals and diets, according to Lee and Rajoo (1987, 394), most Tamil-speaking Hindus are Saivites (worshipping Siva and his associate incarnations), while most Telugus, Malayalis and North Indians worship Vaisnavite deities (Vishnu and his incarnations).

The caste or lineage (ancestral) temple is another type of temple that is often in Agamic structure. According to Arasaratnam $(1979,167)$ and Lee and Ackerman $(1997,91)$, lineage temples are those managed by high-caste Indian Hindus of the same lineage and/or kinship ties. For example, Murugan temples were managed by the Chettiars because Murugan is the deity for the Chettiar caste (Arasaratnam 1979, 168). These lineage temples were often in Agamic forms. The structure of the temples is distinct and often reflected the caste identity of the community the temple served. Furthermore, trustees who often own the temple lands also manage these temples. Mearns $(1987,288)$ also found Chettiar groups manage temples and property collectively. Chettiar temples around Peninsular Malaysia are places for their gatherings and meetings on religious festivals.

The demolished and relocated Hindu temples in the three case studies for this thesis are community temples. A community temple serves the Indian Hindu communities of mixed caste and class, who live or have lived in a specific area (Aveling 1978,176). These temples often house Kaliamman and Mariamman village deities. This type of temple comprises those from the estates, urban and suburban villages. The structure of these temples is varied, mainly because many of them have undergone refurbishment over the years. Some of the temples built by Indian labourers also continue to serve these communities. In the three case studies, I demonstrate how the processes of the demolition have compelled the management committee and the devotees to re-consider and re-instate the roles they play in establishing and maintaining the institution of their community temple. This is especially 
so when the management committee decided to comply with the authorities for demolishing their community temple, and they would have to rationalise and convince the devotees that they have made the right decision. This is because the management committee not only needed the concerted support from the devotees to convince the authorities with their conformity acts, they also needed the participation of the devotees in the temple for it to function effectively as a community temple. A well-functioned community temple would then be able to sustain its higher social position among the community. In the following section, I further review the implications of the fragmentation among Indian Hindu communities on their political representation.

\subsubsection{Political Marginalisation of Indian Hindus in Malaysia}

In this section, I focus on the literature about the subsequent development of the Indian communities in Malaysia and the fate of the Hindu temples that were meant to be temporary structures by the British government and European planters. This includes a review of literature about the developments of politics, society and religion, and the effects of such developments on the Indian communities that remain in Malaysia.

On the onset, as noted earlier, about eighty per cent of Indian labourers were sent home after they completed their indenture contract. However, the British had not accounted for the remaining of about twenty per cent of the Indian Hindu labourers who chose to stay in Malaya, when they presumed the Hindu temples as just mere temporary structures. According to Chanderbali $(2008,34)$, those Indian Hindu labourers eventually started their own families, built houses and even owned livestock and other properties in Malaya. Some of them believed that when they left India, they had already cast away their caste identity (Chanderbali 2008, 35). After the Independence of Malaya and the departure of the European planters, most of these labourers who chose to stay in Malaya continued to reside in the Western rural part of the Malay Peninsula as plantation workers (Sandhu $1969,217)$. The pattern of settlements in the estates and plantations remained the same as during the colonial period. These settlements consisted of temples and shrines, Tamil language schools, shops as well as cultural, social and political organisations (Loh 2003, 224). I suggest that for the Indian Hindus who remained as labourers in the estates and 
plantations, they may not have the financial means in acquiring the land that the temple is situated on. In comparison with the Agamic Hindu temples that are located in urban areas, these illegal temples have become even more vulnerable. This explains the reason as to why lineage temples have remained safe, but the community temples that served the Indian Hindu labourers and their descendants often remained unregistered, undocumented, and eventually faced by threats of demolition from the authorities.

While many Indian communities remain in the estates and plantations, Malaya after independence continued to develop. For instance, a series of political events proved to political leaders that communal-based politics was acceptable for Malayan society. The Alliance was formed between a Malay dominated party, the United Malays National Organisation (UMNO), and the Malaya Chinese Association party (MCA) and Malayan Indian Congress party (MIC). The Malay Muslim leaders who represented the majority of the country succeeded in negotiating with the Chinese and Indian politicians to institutionalise the bumiputera policy and Islam as the national religion in the Malayan Federal Constitution. ${ }^{7}$ In exchange for this policy, the Malay Muslim leaders agreed to jus soli citizenships and freedom of religion for other races. ${ }^{8}$ Lee (1986b) argues that not all people were satisfied with agreements made between the political leaders, especially the acknowledgement of the Malay constitutional privilege. The policies that define the citizenship of different races had sow discontent among different racial groups (Nagata 1979). For many Indian communities, the agreement made by the Indian political leaders to the special rights of the Malays in the constitution was perceived as a betrayal. The simmering communal tensions between different ethnic groups reached a boiling point when the economic conditions of the country plummeted soon after independence in 1957. While the Chinese continued to thrive in business and trading, the majority of the Malays were suffering from poorer socio-economic conditions. Scholars, in general, concur that the severe disparities in economic distributions between the Malays and non-Malays were the

\footnotetext{
${ }^{7}$ The bumiputera policy entails acknowledging the Malays as bumiputera, and they are entitled to special privilege, ranging from Malay reserved land; racial quota system in public services; business licenses and permits to public scholarships and education grants (Lee 2009, 70).

${ }^{8}$ Based on the concept of jus soli, the residents in Malaya who were born in the federation after independence will become the citizens, and the non-residents could qualified as citizens of Malaya by fulfilling requirements of residence, language and oath of loyalty (Lee 2009, 70)
} 
major contributing factors to the increasingly serious racial antagonism (Singh 2001; Jomo 1990).

Alongside the prevailing racial tensions, the Alliance was also losing political support from the people. The Malays felt economically deprived, despite their guaranteed political power (Singh 2001). Many of them blamed the Alliance for their policies that resulted in uneven development, especially between the Malays and non-Malays. For the non-Malays, on the other hand, the special privileges of the Malays as the bumiputera of Malaysia had been unsettling. They remain cynical of the Alliance political policies that benefit only the Malays (Means 1972, 54). The situation persisted until the first general election in 1968. The Alliance received the hardest hit from the results of the election (Stenson 1980, 196). They lost about half of the total votes from the Malays, while the majority of the non-Malays decided to vote for the ethnic-based opposition parties. The results from the 1968 election also denoted drastically reduced popularity for the Prime Minister, Tunku Abdul Rahman. Subsequently, Tunku, having lost two-thirds majority in parliament, resigned. The Alliance lost Penang, Kelantan and Perak to opposition parties, which shook the status quo of political power for the Malay Muslims-led government.

The dramatic loss in the 1968 general election have made the Malay Muslim leaders realised that they are not-so-large of majority to dominate the political arena of Malaysia. ${ }^{9}$ Hence, their loss in the election was translated quickly into a threat to the Malay Muslims privilege and political control over the country. Soon after the election results were announced, the opposition parties staged public demonstrations for their political victory. The Malays from outside the capital were quick to respond by joining the Alliance's counter-demonstrations against the supporters of the opposition parties. Such public

\footnotetext{
${ }^{9}$ Based on the available data of Malaysian population census in 1957, about forty-eight per cent of the total population in the Peninsular Malaysia, including Singapore, were Chinese (thirty-seven per cent) and Indian (eleven per cent) (Fernandez et al. 1975, 13). Hence, Malays constituted about fifty-two per cent of the total populations (approximately 6.3 million people). In 1970, the population census had shown Chinese constituted thirty-five per cent and Indian were about eleven per cent, while the Malays were about fiftythree per cent of the total population in Peninsular Malaysia (the total population is about 8.8 million people) (Fernandez et al. 1975). In fact, in the contemporary context, Maznah (2010) argues that the Malay Muslimled government have continued to implement state-directed projects of "making-majority" to consolidate group solidarity and homogenisation through Islam and Shariah, to ensure that Malay Muslim remain as majority in the Malaysian society.
} 
demonstrations brought the simmering racial tensions to a boiling point which led to the violent racial riot on 13 May 1969 (Means 1972). The police took five days to contain the situation, while Tunku declared a state of Emergency nationwide. Lee (1986c, 34) firmly argues that the 13 May racial riot is another watershed in Malaysian political history. This is because the riot had set off the momentous measures by the ruling government to concretise the special privilege and political benefits for the Malays. The Malay Muslim privilege and ruling power have since become 'the sensitive issues' that are not to be challenged (Lee 1986a). ${ }^{10}$

In the midst of political and social tensions in Malaysia, the Indian communities are also facing another set of problems on their own. Since the establishment of the MIC, the party has been perceived to be an elitist party that disregards the political interests of the majority Indian labourers remaining in the estates and plantations (Supernor 1983, 179; Ampalavanar 1981). Willford (2007) argues that "although [Malaysian] Tamils as a whole are becoming increasingly marginalised [due to the governance of the Malay Muslim-led government], they are not rushing to band together to meet this threat.... Particularly among members of the middle class, for they have much to lose by rallying together working-class Tamils against the BN coalition"(293). As a result, the gaps between different classes of Indian Hindus continued to widen.

Therefore, even though the MIC was a part of the Alliance government, the lower class of caste Indian communities continued to be politically under-represented especially during the important periods of the 1950s until 1970s (Lian 2002). The 1950s was the period when the non-Malay political leaders were negotiating citizenship with the Malay leaders. However, Ampalavanar $(1981,126)$ argues that the Indian communities were still undecided about where they belonged; whether to India or Malaysia. Hence, they appeared

\footnotetext{
${ }^{10}$ Before his resignation, Tunku stated in the parliament that, "The last elections resulted in chaos and shook the very foundation of unity... because opposition parties criticized Malays rights and brought up other sensitive issues," (quoted in Means 1972). Subsequently, the ruling government prohibited public discussion or criticism of 'the sensitive issues'. These sensitive issues are defined in the constitutions as those issues related to the supreme status of the Malay Rulers, the special privilege of the Malays as the bumiputera of Malaysia, Bahasa as the national language of Malaysia and the citizenship rights (Means 1972, 58). The new Prime Minister, Tun Abdul Razak justified that the amendments pertaining to 'the sensitive issues' are necessary to prevent any possible recurrence of the May 13 incident.
} 
to be uninterested in the citizenship negotiations compared to their Chinese counterparts. Furthermore, the 1970's is the period when the Islamisation movements was gaining significance among Malay Muslims in Malaysia. I will further review the literature about the implication of the Islamisation movements on the religious freedom of Malaysian Indian Hindus, in the next section. In this section, it is important to note that the Indian Hindu leaders in the MIC were faced with a dilemma of being unable to convince the upper- and middle-class Indian Hindus of their political aspirations. Concurrently, they also faced difficulties in gaining trust and support from the lower and working class of Indian Hindus, especially from those who continued to live in the estates and plantations and those living in poverty or slums.

With the development of the political context in Malaysia, it has become increasingly clear that the Indian Hindu communities, especially those who are the descendants of the lower class and caste were often falling between the cracks of the on-going political and social debates. As a result, these Indian Hindu communities have often been left to fend for themselves. I suggest that conformity and compliance of the Penang Indian Hindus have reflected their attitudes of fending for their own community Hindu temples. The management committees and local Hindu communities for these Hindu temples appeared to have a fierce sense of safeguarding their community temples - to ensure that their community temples are to be relocated near to their community enclaves and would not be permanently destroyed. More importantly, as I will demonstrate in these case studies, the management committees of these temples often attempted to protect their community temples on their own. Hence, they often resorted to pragmatic and strategic compliance and conformity.

\subsubsection{Religious Marginalisation of Malaysian India}

While the government was restoring peace after the riot, an undercurrent of the dakwah movements was making its way to Malaysia. This resurgence of Islamisation movements was due to a callout from the Muslim scholars from the Middle East against capitalism and materialism from the West. The Malay Muslim youths, in particular, responded to the callout. This Islamisation had further accentuated the frictions between the Malay Muslim 
and non-Malay Muslims in Malaysia. In this section, I review the literature about the effect of the Islamisation movements during the 1970s on the religious freedom of non-Muslims, specifically the Indian Hindu minorities. I highlight how the scholars have demonstrated the marginalisation and discrimination against the Indian Hindu minorities by the Malay Muslim-led government.

In general, the Islamisation movements were driven mainly by a group of Malay Muslim youth. These Malay Muslim youth who were influenced by the Iranian Revolution and other Islamic developments in the Middle East. They consolidated their support and formed the Muslim Youth Movement of Malaysia (ABIM), which had a membership of about 35,000 nationwide (Nagata 1980, 423). ABIM constituted a group of political and religiously active youths, who had experienced the racial riot in 1969, and had participated in the Muslim separatist movements in South Thailand and the Baling demonstration. ${ }^{11}$ One of the main agendas of the ABIM was to institutionalise Syariah law and to instil Islamic culture within Malay Muslim society. The ABIM managed to establish its own religious schools and a college. Its modernist and Islamic appeals attracted many Malay Muslim youths from both urban and rural areas. Their influence was reflected in the ways that many Malay Muslim youths had changed their way of clothing, interaction habits with the opposite sex, and the particular emphasis on the requirement of halal (lawful) foods and attendance at the Friday prayers (Nagata 1980, 415).

Due to the momentous influence of Islamisation, politicians from the UMNO party had started to see the Islamisation movements as a threat to their status quo political power in Malaysia. It was particularly worrisome for the UMNO politicians as the movements denoted similarities to the religious agenda of the opposition Islamic party, the PanMalaysian Islamic Party (PAS). The growing popularity of the ABIM became increasingly alarming for UMNO as well. UMNO recognised the threats when three of ABIM leaders decided to run for the general election of 1978 as PAS candidates. However, UMNO leaders were also aware that they had to tread delicately in containing the dakwah movements

11 The Baling demonstration was staged by a group of students who were protesting for peasant starvation and sufferings in numerous Malay villages near Baling, Kedah (Nagata 1980, 408). 
while enabling them to win the support from the members of the movement. They utilised the government machinery to organise dakwah organisations and programmes, such as the establishment of the National Islamic Dakwah Foundation under the Prime Minister's Department, Dakwah Training Institutes and the proposals for the establishment of the Islamic Economic Development Foundation and Islamic Bank (Nagata 1980, 430). The then Prime Minister, Tun Abdul Razak had tried to recruit Anwar Ibrahim, the spearhead of ABIM, to join UMNO.

Nagata (1980) and Barraclough (1983) contend that the implications of the government's dakwah movements to appease the Malay Muslim majority was often at the expense of religious freedom for non-Malay and non-Muslims. Nagata $(1980,432)$ observed that one of the government strategies to woo for support from supporters of dakwah movements was to excoriate common enemies - the infidels and non-Muslims. This further reiterates the already deeply rooted racial antagonism between Malay Muslims, non-Malay and nonMuslims. Nagata (1980) observed an instance of the government backing the campaign against the Chinese in Penang erecting a statue of the Goddess of Mercy, which would be taller than the state mosque. This has further strained the relationships between Malay Muslims and other ethnic and non-Islamic groups. For non-Malay and non-Muslims, the government is perceived as the upholder of Malay Muslims' privileges, reiterating racial antagonism between Malays and non-Malays. Belle (2008a) argues that many Malay Muslims in Malaysia were piggybacking on the dakwah movements to amplify the display of Islamic symbols, rituals and practices. They utilised the movements as a mechanism to emphasise, reinforce, and perpetuate non-Malay as foreign immigrants. Their objective was to devalue the civilizational heritages and accomplishment of the non-Malays. Belle (2008a) argues that the dakwah movements denote the Malay Muslim's view of Islam as the final bulwark of Malay exclusiveness and the potential or actual basis for political mobilisation.

Under the insurgent Malay Muslim dominance in Malaysia, the ways that different Malaysian Indian Hindus, especially those from the lower classes continue to fend for themselves become increasingly prominent. An example is the infamous Kampung Rawa 
incident in Penang that happened in 1998. The dispute between Indian Hindus and Muslims was provoked by the destruction of the Babri Masjid in 1992, of which a video clip was distributed among Indian Muslims. According to Loh (2003, 226-30) and Munusamy (2012), the friction between the Indian Hindus and Muslims reached a tipping point when the ringing of the Hindu temple bells interfered with the usual Muslim Friday prayers in Kampung Rawa. Subsequently, disputes sparked off between the Indian Hindus and Muslims in Kampung Rawa. As a result, the government requested for the Hindu temple to be relocated elsewhere. The management committee of the Hindu temple complied, and the statues of the deities in the temple were relocated the next day. However, the government was unable to control the spreading of intra-ethnic conflicts that happened on the internet (Stark 2006, 392).12 Subsequently, thousands of Muslims, mostly Malays, came to the mosque in Kampung Rawa after their Friday prayers on 29 March 1998. According to Stark (2006), these Muslims showed up to "assist the state authorities in preventing further Hindu disturbances" (392). Subsequent conflicts between the Muslims and Hindus persisted until April 1998. As a result, a few Hindu temples and shrines were desecrated, a mosque was vandalised, and a few Indian Muslim and Hindu stalls were destroyed in Penang.

According to Stark (2006) and Loh $(2003,229)$, the Kampung Rawa incident was an outburst of the prevailing social, economic and political marginalisation of the Indian Hindu communities. The government's request for the temple to be relocated to thwart the dispute was perceived as favouritism by the government towards the Muslims, which also made it apparent that the Hindus were losing out in the dispute. The compliance of the management committee reinforced the perception that they were being victimised in the dispute. Furthermore, after the incident, the government called for a nationwide review of unlicensed houses of worship (Hutter 2004, 172). Non-Muslims believed that the review was the government's action in demolishing these religious buildings.

\footnotetext{
12 The temple is currently located at S. P. Cheliah Road. It was situated side by side with another five Hindu
} temples, which have recently been relocated due to the re-development of Kampung Jawa Baru. 
Nevertheless, I suggest that the compliance of the management committee of the Hindu temple in relocating their community temple had been a pragmatic move. This is because their compliance that appeared submissive could help dissolve the tensions with their Muslim neighbours in the area. During the fieldwork of this study, I met with the chairman of the Hindu temple that was relocated as a result of the incident. According to the chairman, as they were willing to relocate the temple, the local council of Penang has allocated a land about 200 metres away for the committee to build the temple. "The Municipal Council of Penang gave us this new location... The MIC chairman at that time allocated RM30,000 [approximately NZD10,500] for us, and Samy Velu [the former president of the MIC] gave us RM20,000 [approximately NZD7,000], and we also received money from others to rebuild the temple. We held our consecration ceremony for the new temple in 2008." Their decision to comply with the government in relocating their temple facilitated a smooth process for the relocation. The management committee not only received a new and entitled location for the temple but also received compensation from various authorities for the new building.

The response provided from the chairman suggested that the compliance of the management committee to the demolition and relocation of their community temple was an active political act of manipulation on ensuring the continuing existence of their community temple. Hence, instead of perceiving the Kampung Rawa case as proof of the Malaysian government in discriminating the religious freedom of the Indian Hindus, a shift of perspective to the case has revealed how the Indian Hindus have been responding actively and practically to their political and social surroundings. Such shifts of perspective could open up possibilities for a deeper analysis of the significance of a Hindu temple in Malaysia. The willingness of the Indian Hindus to have their community temples demolished and relocated suggest a contribution to the existing literature on how a Hindu temple as a sacred place is susceptible to demolition and relocation with monetary compensations. Furthermore, it is noteworthy that the Indian Hindu communities in the three case studies also demonstrate similar attitudes of avoiding confrontation with the government. It is worth emphasising that such willingness to receive monetary compensation and to relocate their community temple is pragmatic. Scott $(1990,89)$ 
argues that such a pragmatic strategy is farsighted defensive planning. As I will demonstrate in the three case studies, the pragmatic compliant attitudes of the Hindu communities is often not to demand improvement in freedom for religious expressions. Rather, they often tend to blunt potential threats that their community temples would permanently be destroyed by the government.

Based on the literature review above, it is apparent that regardless of the fragmentation and diversity among different Indian Hindu communities, each of them has their sets of political and social contexts. Regardless of their higher or lower class or caste identities, they have been actively engaging with their surroundings in diverse ways. Hence, even for the Indian Hindu communities from lower class or caste, they are not necessarily powerless when facing dominance and encroachments from the Malaysian government. More importantly, their diverse ways of dealing with the dominance of the Malaysian government remain understated. In the following section, I review the literature on the socio-economic conditions of the lower class Indian Hindu communities. This is mainly to identify how previous studies have established and reinforced the powerless positions of the lower class Indian Hindus.

\subsubsection{Socio-economic Marginalisation of Indian Hindus}

As discussed in the previous section, the racial riot in 1969 was a watershed episode in the Malaysian political landscape. The riot not only affected the subsequent freedom of expressions of Malaysian society, but it has also curtailed the economic advancement particularly that of the non-Malays with the New Economic Policy (NEP). In this section, I turn to the literature on the socio-economic marginalisation of the majority of Malaysian India Hindus, especially with regard to the NEP. This plan by the government has not only reiterated the dominance of the Malay Muslim-led government, often at the expense of socio-economic advancement of other ethno-religious groups. Above all, the policies have further reinforced the racial antagonism among different races. Moreover, scholars continued to identify the lower class Indian communities as the most powerless groups in the face of the dominance of the Malay Muslim-led government. 
The controversial NEP was formulated in 1971, as a measure by the government to counter the racial resentments that caused the serious riot in 1969. The Malaysian government identified the main factors for the riot as due to the deepening racial antagonism among different races, and the severely imbalanced socio-economic conditions between the Malays, Chinese and Indians (Belle 2015). There were two fundamental objectives of the NEP - "to eradicate poverty irrespective of race and the restructuring of society so as to eliminate the identification of a race with its economic functions, a legacy of the colonial times" (Anbalakan 2003, 379). Nonetheless, the Malaysian government had also identified that the Malays and other bumiputera communities had suffered economic backwardness the most, among the three main races. Therefore, the Malaysian government justified that in order to achieve the equitable sharing of the benefits of economic expansions, the Malays and other bumiputera communities were in need of affirmative policy from the government to improve their economic conditions. Hence, the NEP took twenty years to plan to ensure the Malays, and bumiputera would enjoy a thirty per cent stake of nations wealth distributions, non-bumiputera forty per cent and the remaining thirty per cent for foreigners (Anbalakan 2003). Such distribution entailed a larger allocation of land for the rural Malays; allocating opportunities for the Malays in new industries, and special financing and technical assistance for the Malay owned enterprises. As such, the socioeconomic wellbeing of the Malays continued to be the main focus of the government's policies until the 1990s (Jomo 1990).

Scholars found that the Indian communities, especially those from the lower class received the hardest hit from the NEP. Anbalakan $(2003,383)$ argues that the government had made the unjust move to group the Indians with the far-better-off Chinese community. Due to their low education and conditions of poverty these Indian communities had not improved, with the majority of them persistently dominating the low-income occupations. Although the Malaysian government had allocated forty per cent of national wealth distribution for the non-bumiputera, the Indian communities were only holding one per cent of the total distribution (Anbalakan 2003). Hence, it was apparent that the NEP was an economic framework to help the bumiputera in particular, while most of the Indians were obviously more impoverished (Anbalakan 2003, 384-6). 
Besides this stagnancy in economic advancement, Manickam $(2009,165-8)$ also argues that the NEP had not helped to alleviate the conditions of poverty of the Indian communities, especially those remaining in the estates and rural areas. One of the significant impacts of NEP was the increased emigration of former Indian plantation labourers to the urban areas. Nevertheless, as a result of massive emigration, these poor Indians were placed in the "high-rise slums" perpetuating further the culture of poverty and social isolation among them (Gopal and Karupiah 2013,117). The younger generations of the Indian communities in both the rural and the urban slums had remained poorly educated, and school dropout rates were high among them. Although the NEP lasted for only a twenty-year period, the subsequent government's plans such as the National Development Policy (NDP) and the National Vision Policy (NVP) also had not improved the socio-economic conditions of the Indian communities (Manickam 2009).

A series of political, social and religious development in Malaysia after Independence established and relentlessly reinforced the marginalisation and discrimination that majority of Malaysian Indian communities have faced. Based on the literature review above, it is apparent that the Indian migrants that came to Malaya as labourers have experienced the much-needed improvements in their socio-economic conditions. More importantly, arguments from the previous studies above appeared to have taken root on the basis that the Malaysian Indian communities were powerless and hence remained submissive. It also noteworthy that none of these previous studies has suggested that the submissiveness of the Indian communities could be pragmatic, especially if they were often left to fend for their own livelihoods. I argue that by continuously implying that these communities were powerless and submissive, these previous studies have rendered it impossible for these Indian communities to engage actively with their political and social realities.

However, I by no means suggest that these studies are not useful. On the contrary, such reinforcement of the notion that the lower class Indian Hindu communities are powerless could be beneficial for the communities. In fact, my analysis has suggested that the Indian Hindu communities from lower class backgrounds have also been reinforcing such notions 
that they are powerless to go against the government for demolishing and relocating their community temples. Paradoxically, it is because of their display of submissive and powerlessness, they have earned themselves the leeway to relocate the temple, and prevent it from being permanently destroyed.

\subsection{Politics of 'temple cleansing.'}

Besides the political and social background of Malaysian Indian Hindu communities as discussed above, the political interests surrounding the contemporary issue of Hindu temples demolition is also a contributing factor for the conformity and compliance exhibited by the Indian Hindus in Penang to be effective. In this section, I review the secondary resources in exploring the political interests of the Hindu temples demolition in Malaysia. I argue that the political interests at the national level are important in shaping the political context in Penang under the governance of DAP. Subsequently, I also review how the political relations between the DAP and the BN-led Malaysian government influence the conformity and compliance attitudes of the Indian Hindus. I also ask: How effective are the conformity and compliance attitudes of the Indian Hindus in negating the hegemony of the DAP-led state government due to the political context of the issue at a national level?

The issue of Hindu temples demolition became prominent when thousands of Indian Hindus participated in the HINDRAF-led rally that was held in November 2007. The HINDRAF campaigns encompass issues about the marginalisation and discrimination of Malaysian Indian Hindus. On 12 August 2007, the HINDRAF leaders handed an 18-point memorandum to the then Malaysian Prime Minister, Abdullah Badawi. The memorandum contained eighteen demands, which the HINDRAF leaders identified as the main areas of marginalisation and discrimination suffered by Malaysian Indian Hindus that were inflicted by the Malaysian government over the past fifty years. The tenth demand was specifically about the issues of demolition:

10. Stop the indiscriminate unconstitutional and unlawful demolitions of Hindu temples, crematoriums and burial sites in Malaysia. 
- All existing Hindu temples, crematoriums and burial sites be granted state land and permanently gazetted as Hindu temple reserves as has been done for all Islamic places of worship and burial sites.

- Compensation at RM10 Million per temple be paid by the UMNO controlled Malaysian Government for the 15,000 Hindu temples demolished up to date over the last 52 years. ${ }^{13}$

- Every individual is given the Right to practice and profess Religion/s of his/her choice in accordance with Standards adopted by the Universal Declaration of Human Rights 1948.

- The State and its Authorities barred from interfering in the personal beliefs and conscience of individual citizens.

- Disputes between Muslims \& Non-Muslims should be adjudicated in the Civil Courts. (HINDRAF 7 August 2007)

This tenth demand appeared to reflect the determination of the HINDRAF leaders in seeking justice for the demolished Hindu temples. Their determination is driven by their larger cause in fighting against the government for discriminating against the communities. The particular demand of RM10 million (approximately NZD3.5 million) in compensation for the demolished Hindu temples by the "UMNO controlled Malaysian Government" identifies the perpetrators of the issue. Nonetheless, the HINDRAF leaders' demand that all existing Hindu temples be granted state land and permanently gazetted as Hindu temple reserve reflected that they acknowledged the fact that many of these Hindu temples were indeed illegal under Malaysian law. Even though these temples were illegal, the HINDRAF leaders demanded that the government respect their religious freedom and grant these illegal Hindu temples legal land entitlements such as those given to mosques. It is noteworthy that the National Council for Islamic Religious Affairs Malaysia has requested the local government to establish a community mosque in areas with at least forty Muslim households (Federal Department of Town and Country Planning Peninsular Malaysia 2002,

\footnotetext{
${ }^{13}$ UMNO is an acronym for the United Malays National Organisation. It is one of the oldest Malay political parties in Malaysia. Being the largest party, it is also the leading party in the coalition of the BN (Barisan Nasional) - the ruling government of Malaysia. The main political principle of UMNO is Malay nationalism.
} 
23). Hence, the HINDRAF leaders had implied that the issue of Hindu temples demolition had been embedded by a larger issue of increasing dominance of Islamisation in the country. Even so, the alleged 15,000 Hindu temples that were demolished by the government remained questionable. It could be that the HINDRAF leaders exaggerated the number of demolished Hindu temples as a means of seeking public attention.

Although the HINDRAF leaders have published a list of seventy-nine demolished Hindu temples as well as the demolition and relocation notices by the Kuala Lumpur City Hall (DBKL) and the Petaling Jaya City councils on the internet, they did not disclose any details of the 15,000 demolished temples. Indeed, Ramanathan $(1995,95)$ estimated that there were about 17,000 Hindu temples in Malaysia in 1991. These temples included shrines and small temples, which were used for mediumship and worship of guardian and village deities and the more elaborate and properly maintained Agamic temples. Moreover, no available data could verify if the number of Hindu temples has increased or decreased over the years. Despite this, the HINDRAF campaign appeared to have gained responses from the Indian Hindus who participated in the HINDRAF-led rally. Even the HINDRAF leaders were not prepared to have such mass support from diverse Indian communities (Bunnell et al. 2010, 1259). According to Noor $(2008,4)$, the rally constituted two simultaneous demonstrations, one at the capital of Kuala Lumpur and the other at a Hindu temple in Batu Caves. There were approximately 30,000 to 40,000 Indian protesters who participated in the rally (Khoo 2010).

The rally was attributed as one of the factors that rattled the political status quo of the country, which was reflected in the results of the 2008 general election (Noor 2008; Dasgupta 2013). The effect included the resignation of the then Prime Minister, Abdullah Badawi because of losing the two-thirds majority in the Parliament. Although Samy Vellu, the then president of a major Indian political party, Malaysian Indian Congress (MIC), was quoted in reassuring the Indian Hindu communities of the government's support in resolving matters related to the temples (The Stateman 26 December 2007), he too lost the seat in the election and subsequently resigned from the position as the MIC chairman. 
The results of the 2008 general election have created the issue of Hindu temples demolition as an important one for the Malaysian government, politicians and Hindu leaders to take note of. For instance, the Kuala Lumpur City Hall (DBKL) demolished an alleged illegal Muneswarar Kaliyaman temple at Jalan P. Ramlee in November 2013. The case gained prominence when DBKL demolished the temple a week after the celebration of Deepavali. Based on this case, however, reactions from the politicians had been different when compared with the events of temples demolition that happened before the HINDRAF-led rally in 2007. The police detained politicians from the MIC and the opposition party, Parti Keadilan Rakyat (PKR), as well as representatives from HINDRAF, for trying to stop DBKL from demolishing the temple (Lim and Chooi 1 September 2013). The entire episode concerning the demolition and the commotion between the politicians and the police were reported extensively in online media and mainstream newspapers. The Federal Territories Minister, Adnan Mansor, who was being pressured by the politicians and NGOs, denied that DBKL was demolishing the temple. Rather, according to Adnan, DBKL and a private developer had struck a deal with the managing committees of the temple. Adnan was quoted as saying, "We told them (DBKL) not to break any idols. We will beautify the place as fast as possible" (MalaysianDigest 11 November 2013). He also claimed that the demolished structure was not a 'temple' but a 'shrine', with the intention of downplaying the significance of the structure to the community.

Although the Malaysian government had not stopped the demolition of the Hindu temples, they had become more interested in obtaining electoral support from the Malaysian Indian Hindus. After realising the significant impact of HINDRAF on influencing the electoral support from Indian Hindus, the BN-led government had attempted to win the Indian Hindus over through HINDRAF. Before the 2013 general election, Najib, who succeeded Abdullah Badawi as the new Prime Minister, attempted to appease the Indian community by signing a memorandum of understanding (MoU) with HINDRAF (Ariffin 18 April 2013). Subsequently, he managed to persuade one of the founding leaders of HINDRAF, Wayathamoorthy, to publicly urge the Indians to return their loyalty to the BN-led government (Ariffin 18 April 2013). When the time for the general election in 2013 drew near, Najib even lifted the more-than-four-year ban on HINDRAF. His efforts in winning the 
support from Indian voters was reflected in the increased votes garnered from Indians in the states of Selangor and Perak (Chin 2013). Seeing that his approach in appeasing the HINDRAF leader had been effective, Najib then appointed Waythamoorthy as one of the deputy ministers in the Prime Minister's Department after the 2013 general elections. Wayathamoorthy accepted but resigned a year later as he claimed that Najib's administration failed to fulfil the MoU, which was primarily aimed at helping poor Indian communities (Shagar 8 February 2014).

As parts of their continuing efforts to win the support of the Malaysian Indian Hindus, the BN-led government have appeared to be treading more carefully with the issue of the Hindu temples demolition. In January 2018, the state government of Johor had demolished a Hindu temple that was situated on land that belonged to a developer. According to reports, the BN-led state government of Johor had urged the Indian Hindu communities to stay calm and has vowed to find a new location for the Indian Hindus to rebuild their community temple (Malaysiakini 12 January 2018). The attitudes of the BN-led state government in Johor suggest a change of attitude in governing the matter of the Hindu temple demolition as compared to the case that happened in Kuala Lumpur in 2013. Furthermore, during their campaigns for the 2018 general election, the ruling government even vowed that they would stop demolishing Hindu temples in the state of Selangor if the BN candidates were to win the governance of the state (BERNAMA 25 February 2018). Suffice to say that the BN-led government believed the issue of Hindu temples demolition to be important as a means of garnering electoral support from the Indian Hindus and possibly from the other non-Muslims.

The political relevance and significance of the issue of Hindu temples demolition in Malaysia highlighted two important contexts. These contexts explain the pragmatism of compliance approaches of the Indian Hindu communities in the three case studies. Firstly, the DAP-led state government has to avoid demolishing the Hindu temples that illegally situated on private and government lands in order to prevent protests from the Indian Hindu. Moreover, such direct demolition has been perceived as discrimination against the Indian Hindu minorities. Subsequently, being minorities have become an important factor 
for the local Indian Hindus to manipulate the political interests revolving around the issue of Hindu temples demolition, especially after the HINDRAF-led rally. As my analysis throughout the three case studies will reveal, the three communities are aware of the political significance in the issue of the Hindu temples demolition. They are also aware of how the political significance of the issue had constrained the DAP-led state government from openly demolishing their community temples that were situated on private lands. Their subsequent actions in safeguarding their community temples from demolition by the government reflected their awareness of their political surroundings. I agree with Scott $(2008,319)$ that the official platitude, as in this study that the Malaysian political and social context for Indian Hindus, should not be perceived to be cohesive or uniform as it is often imagined. Instead, the political and social context for Malaysian Indian Hindus is subject to different interpretation, depending on the social positions of the communities. As Scott $(2008,319)$ continues to stress, the divergent interpretations of the subordinate (in this case, the Indian Hindu communities) are rooted in their daily experiences. Hence, it is important to gauge the experiences of the Indian Hindus when the government is demolishing their community temples in comprehending their political and social realities.

Moreover, even though the HINDRAF-led rally has attracted many scholarly interests, studies about the rally, however, were often focused on media framing (Lai and Ishak 2012) and social media reports (Leong 2009). With the three case studies in Penang, I suggest for a shift of perspective in analysing the issue of Hindu temples demolition. I suggest that the HINDRAF-led rally also contributes to increasing political interest in the issue of Hindu temples demolition. The rally is also a significant factor influencing the responses of the Indian Hindu communities in the three case studies in Penang. Specifically, my analysis focuses on how the Hindu communities manipulate the rising political interest in dealing with the hegemony of the DAP-led state government.

I also suggest that the responses of the Indian Hindus toward the demolition of their community Hindu temples by the government affect the existing significance of the religious building to the Hindu community. In the three case studies, the existing structures of the three temples had been destroyed. Nevertheless, the government had agreed to find 
a new location for each of the management committees to rebuild their community temples as well as arranged a temporary building for each of the temple committees to house the statues of the deities. Such demolition and possible relocation of these Hindu temples suggest that the management committee of these three temples were adaptable to the drastic changes implemented on their community temples. Their willingness to conform and to comply to the demolition and relocation of these temples invite the question on the importance of these temples to these three communities. While the management committee chose to conform and comply, how did the members of each of the community react to the demolition and relocation?

To examine the susceptibility of the management committees and the communities of these three Hindu temples to the demolition and relocation of their community temples, I discuss the significance of the community Hindu temples in the next section. I explore the establishments of these Hindu temples that was gathered from historical research and the contemporary context. I ask: What are the possible reasons for a Hindu temple in Malaysia to be situated on private lands? I also explore the significance of Hindu temples for different Malaysian Indian Hindus. How does the diversity of Indian Hindus influence the issue of Hindu temples demolition?

\subsection{Conclusion}

In this chapter, I have explored and examined the secondary sources in understanding how compliance and conformity can be effective, pragmatic strategies for the Indian Hindu communities in the three cases of demolished and relocated Hindu temples in Penang. First, I suggest that compliance and conformity are effective because of their minority social status. I have reviewed the literature about their minority and subordinate statuses that consistently reinforce the notion that they are powerless to protect their own religious freedom. I have also traced the claims by the affected Indian Hindus that their Hindu temples were more than a century old. The arrival of Indian Hindus as indentured labourers was the main reason that many Hindu temples remained on private lands. When Malaysia gained independence, Hindu temples became effective institutions that reinforced fragmentation between Indian Hindus. 
The literature review has simultaneously projected the political and social contexts for the issue of Hindu temples demolition in the country. The notion of Indian Hindus as powerless minorities under the given Malaysian political and social contexts are important for me to assess the effectiveness of the strategic and pragmatic acts of conformity and compliance by the Indian Hindu communities of the three case studies in Penang. I have suggested that the increasing political interest in the Hindu temples demolition issue is one of the key factors in making the conformity and compliance of the Indian Hindus to be effective and pragmatic. This is because not only the DAP, but the BN-led government has also recognised how their management of the issue could affect the amount of political support they could receive from Malaysian Indian Hindus. Hence, although the Malaysian government continued to demolish the Hindu temples that situated on private lands, the government's attitude and approaches were different before the HINDRAF-led rally.

Hence, the literature review in this chapter reflects how the conformity and compliance of the Indian Hindus could be part of their manipulative acts. Their acts reveal how they are aware of their political surroundings, especially in Penang. Their awareness stems from the increasing political interests that surrounded the issue of Hindu temples at a national level. Hence, the responses of the Indian Hindus in Penang were pragmatic and strategic, when the government demolished their community temples. Their pragmatic responses also suggested that the Indian Hindus, especially those from the lower and working classes, are not as docile and submissive to the hegemony of the government as they are popularly perceived to be. Above all, their acts of conformity and compliance are not associated with a sense of powerlessness. On the contrary, their conformity and compliance reveal their awareness of their positions in the political realities in both Malaysia and Penang.

Besides the political interests that surround the issue of Hindu temples demolition at a national level, I contend that the DAP-led state government in Penang has been facing various challenges that are distinctive because of the historical background. In the next chapter, I turn to the various challenges that the state government faced while trying to manage the issue of illegal Hindu temples that are situated on private or government lands. The process of how the DAP-led state government managed the challenges of the Hindu 
temples demolition issue is important in reflecting how the Indian Hindus responded to the request for the demolition of their community temples. I further examine the issue from Penang. 



\section{Local politics of Hindu temples}

\section{destruction in Penang}

When I began my fieldwork, I was advised by the locals to consider changing my research site to other states, such as Selangor or Kuala Lumpur. The main reason was that the Hindu temples in those places were under more pertinent threats of demolition by the local authorities. This is because Selangor and Kuala Lumpur were under the administration of the Barisan Nasional-led (BN or National Front) government. BN replaced the Alliance in 1973; after the inclusion of the regional parties from Sabah and Sarawak. Currently, BN has thirteen political parties under its flagship. The additional alliance has made it the largest right-wing coalition in Malaysia with United Malays National Organisation (UMNO) as the leading party. Thus far, the dominance of UMNO has continued to form a Malay Muslim-led Malaysian government. As critics on the issue have identified the BN government as the main perpetrator of the Hindu temple demolition, it explains the locals' rationale in suggesting Selangor and Kuala Lumpur, which are under the governance of BN, as more suitable research sites in exploring the issue of Hindu temples demolition.

Their advice has identified Penang as an important research location for the subject of Hindu temples demolition in Malaysia. This is not only because the longstanding opposition party, DAP is governing the state by the, but it also has distinctive historical circumstances, from $19^{\text {th }}$ century colonialism. These historical circumstances make it particularly challenging for the state government of Penang to handle issues of Hindu temples that are situated on private and government lands. In this chapter, I explore the local politics in Penang as the research setting for the issue of Hindu temples demolition. I look at the governance of the DAP-led state in examining how "the stereotypes of the dominant are...a resource as well as oppression of the subordinate" (Scott 1990, 34). I further argue that the Indian Hindus were aware of how the political positions and principles of the DAP are 
paradoxically restraining them from directly demolishing the Hindu temples that are situated on private lands. Hence, instead of protesting openly, the Indian Hindus realised that it was more practical to show conformity and compliance. As Scott $(2008,329)$ argues, "If the exercise of domination depends upon a social [and political] context for its creation and maintainence, so does the exercise of resistance". I examine the history and politics of Penang after the 2008 general election by understanding the constraints of the state government in managing the issue of Hindu temples that are situated on government lands. These historical and political constraints of the state government have provided leeway for the strategic tactics of conformity and compliance of the local Indian Hindus in protecting their community Hindu temples from permanent destruction.

\subsection{Penang under the governance of the Democratic Action Party (DAP)}

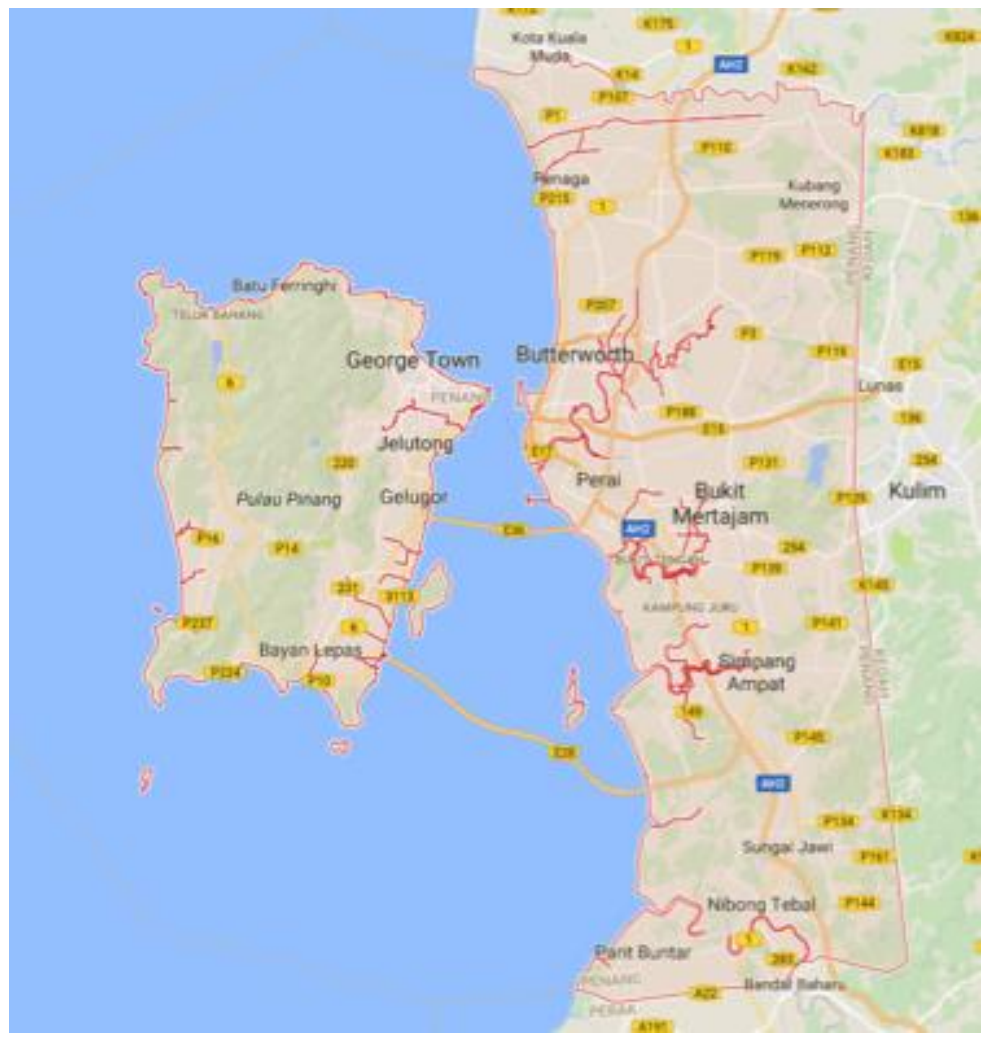

Figure 1 MaP OF PENANG

(Source: Google Maps, accessed 11 September 2017) 
Penang is the second smallest state in Malaysia (about 260,000 acres). As of 2010, it was the eighth most populated out of the thirteen states, having the second highest population density in Malaysia (Department of Statistic Malaysia 2010, 3). Hence, this suggests that Penang has limited usable lands. The population in Penang consists of about 1.5 million Malaysian citizens. Of these, approximately forty-four per cent are Muslims (of which, about ninety-eight per cent are Malays), around thirty-seven per cent are Buddhists (of which, nearly ninety-nine per cent are Chinese) and about nine per cent are Hindus (Department of Statistic Malaysia 2010). This makes the majority of Malaysian citizens in Penang Chinese and Indian. Historically, Penang was also the first place in Peninsular Malaya where the British began its colonialism during the late 18th century (Prorok 1998). Subsequently, the European planters that came to the state established estates and plantations in Province Wellesley (currently known as Seberang Perai). Penang was where the Indian labourers first settled (Tully 2011), which also implies that the state has some of the oldest Hindu temples in Malaysia (Prorok 1998). Many of these temples were built by and for the Indian Hindu labourers. The historical background of Penang indicates that the state may have many Hindu temples that used to serve the Indian Hindu labourers. The background of the state as well as the current political setting suggests the complexity of the illegal Hindu temples issue in Penang.

Penang has been governed by the Democratic Action Party (DAP) since 2008. Since the formation of DAP in 1966, their leaders upheld the principle of 'Malaysia for Malaysians'.1 The party leaders declared that they were fighting for 'a democratic Malaysian Malaysia', as opposed to BN's (Barisan Nasional's) political principle of Malay supremacy (Democratic

\footnotetext{
${ }^{1}$ According to the party's manifesto in 1991, "We remain committed to the vision of a Malaysia in which every Malaysian citizen has a rightful place in the Malaysian sun, where talent and hard work are justly rewarded, where the poor of all ethnic communities are equally assisted, and where sectors or classes and not 'race' are earmarked for special assistance" (Vatikiotis 1992).
} 
Action Party 1969, 1). ${ }^{23}$ Having successfully changed the state government for the first time since 1968, the people of Penang expected the opposition party, DAP, to provide an alternative political setting for Penang. It is important to note that Since the formation of DAP in 1966, their leaders have been upholding the principle of 'Malaysia for Malaysians'.4 The party leaders declared that they were fighting for 'a democratic Malaysian Malaysia', as opposed to BN's (Barisan Nasional's) political principle of Malay supremacy (Democratic Action Party 1969, 1). ${ }^{5}$

Prior to DAP's win over Penang, the state had been governed by the Gerakan party since the 1968 general election. The Gerakan Party is one of the parties in the BN coalition. As stated by Goh $(2009,147)$, "There is no doubt that Penangites are seeking changes. Otherwise, there would have been no reason for them changing the state government." The expectations from the Penang people gave rise to bigger responsibilities for the DAP to bear. Such sense of bigger responsibilities is mainly due to the sense of the insurgent voting

\footnotetext{
2 "By democracy we mean the provisions for the fundamental rights of all our citizens, and the system of parliamentary democracy enshrined in our present constitution. It not only permits divergence of views but also protects the right of any Malaysian to compete for popular influence and support through processes sanctioned by the constitution and for ends embodied in it. A Malaysian Malaysia means that the nation and the state is not identified with the supremacy, well-being and the interests of any one particular community or race ... The special and legitimate interests of different communities must be secured and promoted within the framework of the collective rights, interests and responsibilities of all races. Supporting for the ideal of a Malaysian Malaysia means, in theory and in practice, educating and encouraging the various races in Malaysia to seek political affiliation not only the basis of race and religion but on the basis of common political ideologies and common social and economic aspirations, which is the basis of ensuring the emergence of a truly free, prosperous and equitable national community" (Democratic Action Party 1969, 2).

${ }^{3}$ DAP's election manifesto was titled, "Malaysia can do better!" Their main campaign slogan was, "just change it - change for democracy, a better quality of life and a brighter future for our children" (Mokhtar 2008, 91). ${ }^{4}$ According to the party's manifesto in 1991, "We remain committed to the vision of a Malaysia in which every Malaysian citizen has a rightful place in the Malaysian sun, where talent and hard work are justly rewarded, where the poor of all ethnic communities are equally assisted, and where sectors or classes and not 'race' are earmarked for special assistance" (Vatikiotis 1992).

5 "By democracy we mean the provisions for the fundamental rights of all our citizens, and the system of parliamentary democracy enshrined in our present constitution. It not only permits divergence of views but also protects the right of any Malaysian to compete for popular influence and support through processes sanctioned by the constitution and for ends embodied in it. A Malaysian Malaysia means that the nation and the state is not identified with the supremacy, well-being and the interests of any one particular community or race ... The special and legitimate interests of different communities must be secured and promoted within the framework of the collective rights, interests and responsibilities of all races. Supporting for the ideal of a Malaysian Malaysia means, in theory and in practice, educating and encouraging the various races in Malaysia to seek political affiliation not only the basis of race and religion but on the basis of common political ideologies and common social and economic aspirations, which is the basis of ensuring the emergence of a truly free, prosperous and equitable national community" (Democratic Action Party 1969, 2).
} 
power of many Penangites after the 2008 general election. Above all, my analysis from the case studies in the subsequent chapters reflects that the Indian Hindu communities believe that the DAP-led state government of Penang has the compelling need for adopting a mask in the presence of the Indian Hindu minorities (Scott 1990, 10). This urge to wear a mask is an urge of euphemisms - actions and speeches that constitute the flattering self-portraits of the elites (Scott 1990, 54). As euphemisms are necessary for the elites to normalise their power, Scott $(1990,49)$ also argues the elites are often the consumers of their own performance. Although this study does not include the participation of the state government, the options for them to manage the temples that are situated on others' lands are limited. Such limitations are imposed by their reputation of being a political party that is intended to represent all Malaysians, regardless of race and religion.

Moreover, one of the contributing factors for the victory of DAP in 2008 general election is because of the party concurred with all the demands made by HINDRAF in their campaigns. ${ }^{6}$ Then, during the 2008 general election, DAP formed a joined coalition with two other major opposition parties - the People's Justice Party (Parti Keadilan Rakyat, or PKR) and the Malaysian Islamic Party (Parti Islam Se-Malaysia or PAS). This opposition alliance adopted HINDRAF's slogan 'Makkal Sakti' (People's Power) in their election campaigns as a show of support for the HINDRAF leaders (Mokhtar 2008, 96). Mokhtar (2008) argues that by adopting HINDRAF's slogan, the opposition alliance had attracted the majority of electoral support from the Indian communities, which contributed to its success in the 2008 general election. Since HINDRAF strongly criticised this approach, the DAP-led state government had to find other ways of resolving the issue amicably. As Scott (1990, 11) argues, actions by the powerful that publicly contradict the basis of a claim to power are threatening. The DAP-led state government was restricted from using the similar approach practised by BN, which was to demolish the Hindu temples that were illegally situated on private lands openly. If the DAP uses the similar method as the BN, it might be

\footnotetext{
${ }^{6}$ Other opposition parties leaders, such as the Partai Islam Se-Malaysia (PAS, also known as Malaysian Islamic Party) and Parti Keadilan Rakyat (PKR, also known as People's Justice Party), did not agree with the HINDRAF's demands and accusations about Islam and special privilege of the Malays as the bumiputera.
} 
at the expense of not only their newly gained electoral support from the people in Penang but also their political reputation of 'Makkal Sakti' at the national level.

As the new state government of Penang, the party was aware that they had to perform better than the previous Gerakan-led state government. Hence, the DAP-led state government is compelled to handle the issue of Hindu temples situated on private and government lands with more empathy. Hence, to be seen as more empathetic to these temples, the DAP-led state government have to avoid demolishing these temples permanently, as it would cause discontentment in the local Indian Hindus. The discontentment in the local Hindu communities would threaten their reputation as a party that supports egalitarianism, which might cost them electoral support that the party needs to sustain their state government position in Penang. This also means that the DAP has to tread carefully on matters related to illegal Hindu temples, so as not to spark any discontentment among Malaysian Hindus, which could threaten the former's political reputation as well as the state government position in Penang.

Above all, the Indian Hindu communities of the three case studies in Penang are also experiencing an insurgent voting power after the 2008 general election. One of the participants in this study pointed out, "I speak the truth from my heart. I am not afraid. Ramasamy [the second Deputy Chief Minister of the DAP-led state government of Penang] should be afraid of us."7 Such threat further reflects the challenge for the DAP-led state government in handling the issue of Hindu temples that are situated on private and government lands illegally. Another participant also pointed out that the state government must uphold the promise of finding a new location for them to rebuild their community temple after the former structure is demolished. Otherwise, he said, "They [DAP] will lose 500-1,000 voters here." 8 Such sentiments of not voting for the DAP by both the participants indicated their sense of empowerment through an election. This implied that they were aware of the significant contribution of the people's vote in the 2008 general election, which eventually led to DAP's victory. As Scott $(1990,12)$ suggests, "virtually all

\footnotetext{
7 Translated from: Saya cakap betui punya hati juga. Saya tak takut. Ramasamy takut sama kita.

8 Translated from: Sini punya undi ah ... Habis lah, 500-1,000 undi sudah rugi lah.
} 
ordinarily observed relations between the dominant and the subordinate represent the encounter of the public transcript of the dominant with the public transcript of the subordinate". This also means that the Indian Hindu communities are aware of the mask of empathy (public transcript) that the DAP is wearing. It also suggests that the Hindu communities are aware of the constraints of the DAP-led state government to openly and directly demolish the Hindu temples that are situated on private or government-owned land in Penang.

Besides, the results of the 2008 general election and the increasing political interest in the issue of illegal Hindu temples at the national levels also have made Hindu temples into an effective source for political support from the Indian Hindu communities. Recently, Jagdeep Singh Deo, the state executive councillor board chairman for the Housing and Town and Country Planning Committee, announced that the DAP-led state government has raised funds for non-Muslims in Penang (also known as RIBI- Rumah Ibadat Bukan Islam) to build and renovate their houses of worship (Mok 20 June 2017). A successful applicant could receive up to RM50,000 (approximately NZD18,000) of maximum funding, which is an increase of RM30,000 (approximately NZD11,000) from the initial allocation. The fund was initiated in September 2015 by the state government (Lee 22 September 2015; Tan 23 September 2015). The allocation reinforces how the DAP-led government is respectful towards the religious freedom and expression of the non-Muslims in the state. Such reputation of being respectful may be effective in obtaining and retaining electoral support from the Indian Hindus for the DAP-led state government. However, one of the terms and conditions stated in the fund application was that the managing committees would have to present a certificate of registration and a letter of consent from the landowners and committee members (Seow 21 October 2015). These terms and conditions, however, have not made it possible for the managing committees of Hindu temples that are situated on private or government lands to apply for the fund. It is apparent that the DAP-led state government do not acknowledge these illegal Hindu temples. Hence, these temples would continue to face threats of demolition if they remain on private and government lands. 
Furthermore, when the DAP took over Penang, they were also left with the persistent issue of the lack of affordable housing for local people. According to MacDonald (2011b), the multi-faceted and rapid development led to a drastic increase in house prices (by over fifty per cent in Penang Island and over twenty-five per cent in mainland Penang). The lucrative property market in Penang had attracted more buyers and foreign investors, which led to higher demand for houses in Penang (MacDonald 2011a). As such, the DAP had to cope with the inflation of housing prices in the state while securing profits for the government. Under such mounting pressures, the state government has opted for a more immediate solution, which is to develop more low-cost and affordable houses for the local people (Cheah 2008). The development of these houses requires usable land, which is particularly lacking in Penang due to its geographical nature, historical and political background as well as its high population density. Hence, the state government's real estate development plan was to suggest that the illegal Hindu temples, especially those situated on the state government's land, to make way for new development.

It is noteworthy that the participants of this study appeared to be aware of the challenges of limited usable lands in the state faced by the state government. They are aware of the fact that the government would not allow their community temples to remain as they are at the expense of development plans. When I ask a participant about her opinion on the relocation of a community temple, she said, "What to do, the government cannot stop the development just because of one temple, right?" The submission to the DAP-led state government's request in demolishing the community temple was also because the government had agreed to allocate a new place for the management committee to rebuild the temple. This was evident from the state government's successful negotiation with the land developer in allocating a portion of the land for the community. The same participant explained, "They are professional people, and they are very good. They build this temple for us". The developer had not only agreed to the new allocation, but they had also built a basic structure of the new temple. The relocation of the temple was reported in the newspaper, which highlighted that the state government of Penang managed to persuade the management committees of seven Hindu temples in relocating their temples to make way for the planned construction of new apartment buildings. The developer was quoted as 
saying that the state government would compensate the management committees for the demolition costs and the relocation of their community temples (The Star Online 30 November 2013).

As I will further analyse in Chapter Five, this case is an example of how the DAP is restrained from demolishing these Hindu temples, which has always been the approach of the BN government. As a way of avoiding demolition, the DAP had opted for the relocation of the temples. Relocation entails the process of demolishing and rebuilding the temple at another place. This means that the government not only have to compensate the communities for the demolition and reconstruction, they would also have to find a new location for the communities to rebuild the temple. Despite having the temple demolished and relocated, the chairman of the temple appeared to be satisfied with the arrangement proposed by the state government. During my initial visit and interview with the chairman, he said, "Everything is okay. This [the new location] is the same size". The relocation of the temple also implies that the state government would allow the community to make de facto claims on the lands, at least for as long as the DAP is still in power in the state. The apparent satisfaction of the chairman seems to imply that the DAP government has found a solution in managing the issue of illegal Hindu temples in the state.

Another pertinent challenge is because these Hindu temples are community- based Hindu temples. To get the management committee and the Hindu community to agree to the relocation, the new location has to be easily accessible to the Hindu community that the temple serves. Throughout my fieldwork, I have also visited a Hindu temple that had been relocated by the state government after the former site had been sold to a private developer. The chairman of the temple appeared to be satisfied with the new location because it was easily accessible by the Hindu community. He explained, "The previous situation in the estate, when compared to this place [new location], we are receiving more devotees now because this new place is easily accessible by the nearby residents. Previously, when the temple was in the estate, it was difficult for the devotees to go there. There was no road, no electricity. It was difficult for them. Now, we have more people 
coming here to pray on a daily basis." ${ }^{\prime 9}$ It is noteworthy that the former location of this temple was about 300 metres away. The new location of the temple appeared to have been acceptable as the Hindu community could still visit the temple on a regular basis. It is apparent that if the state government could satisfy the management committee and the Hindu community with the relocation of their community temples, the government is set to gain acknowledgement from the communities. For example, this participant said, "We get this place and the basic structure of this temple because of Ramasamy." 10 The conformity and compliance of the management committee to the government's proposal has enabled the former to obtain a new location in rebuilding their community temple.

Furthermore, although the DAP appeared to have the Indian Hindus' support in the 2008 general election due to the party's cooperative effort with HINDRAF, it is by no means evident that the HINDRAF leaders and the DAP were on the same side when pitting against the BN-led federal government. Instead, the HINDRAF leaders have continued to ensure that they have not taken any political sides, especially in Penang, where the HINDRAF leaders have been actively seeking accountability from DAP in ensuring that the government would not marginalise or discriminate the poor Indian Hindu minorities in Penang. For example, Steele $(2013,70)$ noted in a news report that Uthayakumar, a founding leader of HINDRAF, has alleged that the DAP-led state government had demolished an Indian village on 23 September 2009. About a month later, Uthayakumar even called for the Indians in Penang to boycott the polls of a by-election in Penang. According to Steele (2013), many believed that Uthayakumar's call for boycotting the polls had contributed significantly to Pakatan's loss on the seat. Subsequently, in another news report, the HINDRAF leaders in Penang criticised the DAP-led state government for deceiving the Indian communities with 'hamper politics' (Shankar 31 October 2013). A hamper is a basket of gifts, usually containing staple dried foods. Hamper-giving is a conventional political populist approach for Malaysian politicians to establish and maintain

\footnotetext{
${ }^{9}$ Translated from: keadaan dalam estate dulu, berbanding dengan tapak baru ni, sekarang lebih ramai lah penganut. Sebab mudah untuk penduduk kawasan sekitar ni lah. Dulu agak kedalaman itu tak ada kemudahan asas jalan raya, eletrik susah, menyusahkan penganutnya. Tetapi sekarang lebih ramai lah penganutnya. Sembahyang harian pun ramai juga.

${ }_{10}$ Translated from: ... dia [the developer] bagi pampasan tanah sahaja... dia [the developer] buat bangunan ini sahaja. Semua ini dalam perbincangan, dengan Prof Rama. Kita dapat tapak nih lah.
} 
their clientele relationships with their supporters. The HINDRAF leaders criticised that the hamper-giving would not solve the poverty conditions of poor Indians, rather, the hampers were used to entice electoral support from the Indian communities. These cases reflected how HINDRAF has been keeping watch over how the DAP is managing and assisting the Indian communities in Penang.

It is also important to note that there is an indication that some participants in the three case studies are aware of the state government's intention of hamper-giving as to establish clientele relationships with them. According to a participant, the government's needs to establish clientele relationships reinforce his doubts that they will fulfil the promise of a new location for his community to rebuild their demolished temple. He asked, "They came; they gave hampers for everybody ... Then he said they would expand the landfill and build a factory. Then, Phee Boon Poh and Ramasamy went into the temple; they said they would demolish the temple."11 The participant has recognised that the hamper-giving had been an act of enticement. "... But what is the meaning of the hamper, why they gave it to each [sic] of us?"12 This participant implied that the state government was attempting to buy off the poor estate community in complying with their proposal to have the temple demolished. This also suggests that the state government may not be keeping to their promises. His questioning of the act of hamper-giving also indicated that he was sceptical that the state government would find a new location in rebuilding his community temple.

Although the participant's criticism of the hamper-giving indicated that he was in line with HINDRAF's opinion, it was by no means evident that the participant was agreeing with or supporting HINDRAF. In fact, participants across the three case studies have not brought up HINDRAF while relating their accounts for the safeguarding of their community temples. One of the possible reasons could be that HINDRAF has lost a significant amount of influence on the Indian Hindus, especially after one of its founders, Waythamoothy, decided to accept Najib's offer on being a minister in the Prime Minister's Department in 2013.

\footnotetext{
11 Translated from: Depa mai turun, depa bagi hemper ... untuk semua orang. Habis kami semua sudah terima hamper tu ... Dia kata lain hari sikit mau buat cadangan sampah, mau buat kilang semua mau buat. Tiba-tiba yang Phee Boon Poh sama Prof. Ramasamy dia masuk dalam temple, dia kata ini temple mau diroboh. 12 Translated from: Tapi hamper buat apa, yang itu dia buat hamper tu, what is the maksud? Why the hamper is put there?
} 
Subsequently, the HINDRAF coalition was split into two factions, which were led by Waythamoorthy and his brother Uthayakumar respectively. As a result of the split, HINDRAF's political influence on the Malaysian Indian Hindus began to diminish. Moreover, most of the HINDRAF's followers in Penang had been supporting Waythamoorthy, but with his acceptance of the ministerial appointment from Najib, Waythamoorthy has since been regarded as a traitor. This perception has been reflected in the three case studies. Instead of approaching the HINDRAF leaders in Penang for intervention, I demonstrate how the management committees of the three temples had decided to employ their approaches of compliance and conformity to the DAP-led state government in safeguarding their community temples.

Besides the constraints imposed by the political and economic factors, the limited jurisdiction of the state government in Penang was also due to the colonial history of the state. In the next section, I turn to the literature that touches on the history of land ownership in Penang by identifying the legacy of limited jurisdiction in the current state government over the usable land in Penang. The colonial history of Penang includes the legacy of the Penang Hindu Endowment Board, which is a statutory body that administers the management of Hindu Endowments and Hindu temples in the state. In the next section, I will also review the roles and functions of this Board on the illegal Hindu temples issue in the state.

\subsection{History of land ownership in Penang}

Before the arrival of the British colonial government, all the lands in Malaya were vested under the Malay Ruler. It was only the Ruler of the Council, headed by the Sultan, who could issue land grants (Sandhu 1964, 146). Penang was taken over by the East India Company in 1786 from the Sultan of Kedah. In 1826, the British formed the Straits Settlements, which consisted of Penang, Malacca and Singapore and was overseen by a British Governor. After the formation, the management of the land in the Straits Settlements became the responsibility of the British Governor. Due to the legacy of the British government's management of usable land in Penang, a large number of lands have remained out of the current federal and state governments' reach. I begin this section by 
exploring the colonial history of Penang, particularly focusing on the issue of land management by the British government. I review how this historical context has become an important consideration to the state government's management of the issue of Hindu temples which are located on the government's land in the state.

Due to the British's legacy of land management, many usable lands in Penang have been under perpetual land titles. These land titles were initially known as permanent land titles by the British government. According to Turnbull $(1972,55)$, the colonial government in Penang initiated the permanent land ownership in encouraging the Chinese and Indian merchants to establish and continue their tradings in Penang. In return, the British government could generate revenue from their trading activities to administer the state. According to Turnbull $(1972,144)$, as a result of the colonial government's encouragement, many Chinese and Indians traders started to buy a great deal of land in Penang. Currently, these perpetual ownerships are known as the 'indefeasibility of title'. As long as the owners have registered their inherited lands with the Penang Land and Mines Office, there would be no reporting discrepancies on the usage and management of these lands and will remain out of the state and federal governments' reach. To date, many of these perpetual land titles still stand and have been inherited by the descendants of the Chinese and Indian merchants (Tregonning 1966; Drabble 2000). ${ }^{13}$ These perpetual land titles restrict the state government's control over the usable land in Penang. Such a restriction has hindered the developmental plans of the state government. Due to limited land resources, the Hindu temples that have been situated on lands that belong to the state government in Penang would have to make way for the state's development plan.

Besides the Chinese and Indians traders, the Straits Settlements' government also encouraged many European planters to acquire lands in Province Wellesley, particularly in the southern part of the Province (which is known today as the Southern Seberang Perai district). By 1846, the European planters for sugar plantations had bought almost all of the fertile lands in the southern part of Province Wellesley. After Independence, the European

\footnotetext{
${ }^{13}$ According to Drabble (2000), the Chettiars had owned about 28,000 hectares of land in the Federated
} Malay States, while the Chinese-owned rubber holdings owned about 8,000 hectares of lands. 
planters eventually sold off the lands to the government as well as to the local planters. Although the European planters had left, many of the Indian Hindu labourers had remained in the estates and plantations with their community temples. Since these temples had not been documented, they became increasingly vulnerable as the estates and plantations changed hands over the years. As demonstrated by the contemporary cases of Hindu temple demolitions, most of these temples were deemed illegal for being situated on private lands. For this reason, when the government and private developers decided to redevelop the land, these temples were confronted with threats of demolition. It is also worth mentioning that the first case study for this thesis, which is a temple in the estate, is situated in the Southern part of Province Wellesley. The local estate Hindu community has claimed that the European planters established the temple for the Indian labourers.

Besides the legacy of the British colonial government that allowed perpetual land ownership by way of inheritance, there were lands in Penang, which had been owned by the Muslim and Hindu groups before the arrival of the colonial government. These titles are also known as the waqf land. In Penang, the titles are divided into the Muslim and Hindu waqf lands. These lands were given by donors mainly to build mosques, orphanages and/or religious schools (Nagata 1979, 87). The institution of waqf provides collective ownership, usage and protection for the particular community (Nasution 2002, 300). In 1801, the East India Company gave the Indian Muslim merchants, also known as the Kerling community, a sizable portion of land to build the Kapitan Kerling Mosque (Nasution 2002, 301), thus initiating the establishment of a waqf institution in Penang. The initiation of waqf has enabled the Company to base the Indian Muslim trading community, which is the dominant trading group in Penang. Tengku Syed Hussain Al-Idid, alias Syed Sheriff Tunku Syed Hoosein, endowed the second waqf land in 1808. He was a wealthy Arab trader from the royal house of Acheh who came to Penang in 1792. This land is where the Masjid Melayu Lebuh Acheh (Acheen Street Mosque) still stands today. The communities at Lebuh Acheh (Acheen Street) comprised Arabs, Malays and Sumatrans (Nasution 2002, 300). The 
number of waqf lands in Penang continued to increase over time. ${ }^{14}$ Currently, the general Muslim waqf lands are under the management and authority of the State Religious Council, which acts as the board of trustees of the lands, while some other special waqf lands are inherited by the descendants of the donors of the lands (Nagata 1979).

Based on Malaysian Islamic law, the general waqf land is public property, which cannot be given away, sold, mortgaged, inherited or disposed of (Nasution 2002). Nevertheless, the prolonged conflicts in the administration and management of Muslim waqf lands have since become a long-standing issue. Utusan Online (26 February 2016) once reported that there are about 30,000 hectares of waqf land in Malaysia today, and only twelve per cent of this land has been used for either construction of public facilities such as roads, drainage, and electricity substation sites, or building mosques, schools and facilities for Muslims (Dahlan et al. 2014, 58). Only two per cent of this developed waqf land is in Penang. Furthermore, according to Hisham et al. (2013), many of the waqf lands have become valuable, since they are situated in the state's administrative centres and business hubs. The Malaysian Islamic authorities are aware of the poor management of these waqf lands and have been working towards a better usage of these lands. One of the proposed solutions to better manage the waqf land is by 'Istibdal' (Hisham et al. 2013, 24). Istibdal means to substitute the waqf land with another property or money of the same or higher value, which allows outsiders to obtain the under-developed waqf land. In this way, the waqf land can remain active and is fully utilised.

On the surface, the Istibdal seems to allow the DAP-led state government to acquire the much needed waqf land for its developmental plans. The DAP has attempted to acquire waqf land through Istibdal. According to Hisham et al. $(2013,26)$, the DAP-led state government has acquired a piece of land from the Islamic Religious Council of Penang through Istibdal, with compensation of RM6 million (approximately NZD2.1 million) and 30 hectares of land at a suburb in Balik Pulau. The experience of acquiring the waqf land for

\footnotetext{
${ }^{14}$ Isa et al. (2011) listed the waqf properties in Penang as including: (1) Majoodsaw Waqf where a 21-storey Menara UMNO, eight units of commercial premises, 12 units of accommodation, a three-storey treatment centre, five units of shop lots and nine units of office shops currently stand; (2) Khan Mohamad Waqf (700sqft); and (3) AlimsahWaley Waqf.
} 
the first time proved difficult for the state government of Penang in reaching an agreement with the religious authorities. This is because the religious authorities are cautious with the number of waqf land in the country. A decrease in the Muslim waqf land is perceived as a threat to the dominant position of Muslim authorities. Therefore, the State Religious Council is more inclined to substitute the waqf land with another piece of land as Istibdal (Adil and Rani 2014; Dahlan et al. 2014). For the state government of Penang in particular, the Islamic authorities' preference has made it difficult for them to acquire the waqf land since they do not have control on most of the lands in Penang that can be used for exchange.

Furthermore, the process of waqf land acquisition involves obtaining multiple bureaucratic approvals, and for a non-Malay Muslim party such as the DAP, the process would often be time-consuming. ${ }^{15}$ Nonetheless, it would still be difficult for the state government to acquire waqf land in Penang. This has further restricted the state government's plan for development, which requires more space in the state. The restriction also reflects a higher degree of threats faced by the Hindu temples that are situated on private lands.

Besides the Muslim waqf lands, Penang also has the Hindu waqf land, which is managed by the Penang Hindu Endowment Board (PHEB). This Board is also one of the legacies continued from the British colonial government. The function of the Board in Penang has reinforced the false presumption that the state government of Penang has another body that could effectively manage the issue of illegal Hindu temples. In the following section, I identify how the Board has failed in managing the issue of Hindu temple demolition in the state.

\subsection{The Penang Hindu Endowment Board (PHEB)}

As mentioned earlier, my research interests in the issue of Hindu temple demolition stemmed from my prior mapping survey of Hindu temples in Penang that was funded by

\footnotetext{
15 The Islamic Religious Councils must first obtain consents from the local Muslim community. Then the proposal will be submitted to the state's fatwa committees for approval. The fatwa committees will assess the proposal, especially its potential growth in investments. The Religious Councils will then make a public announcement for the sale of the waqf land through open tender, in order to fetch the best price.
} 
the Penang Hindu Endowment Board (PHEB). The perceptions and reactions from the Indian Hindus and non-Indian Hindus about the PHEB varied. For outsiders, the PHEB could be another channel for the state government in resolving the issue of illegal Hindu temples. For the Indian Hindus, however, their perceptions are mixed. Nevertheless, the Board remained as an important element in the analysis of the three cases, particularly in Penang. In this section, I examine the PHEB from its establishment to the contemporary political context by identifying the functions of the PHEB in the issue of Hindu temples that are situated on private and government lands.

Based on many studies, the establishment of the PHEB was a British attempt at resolving tensions that arose between Hindu communities. The managing committees of Agamic Hindu temples in Penang initiated the formation of the Hindu Endowment Board following a series of complaints in 1905. According to Ramanathan $(1995,171)$, the management committees of the Hindu temples and the trustees of Muslim and Hindu waqf lands eventually deemed it necessary for the British to intervene in matters relating to the land and temples management. This resulted in the passing of the Mohammedan and Hindu Endowments Ordinance 1905. The Ordinance applied to "any endowment in land or money to be used for the support of any Mohammedan mosques or Hindu temples or Mohammedan or Hindu shrines or schools or other Mohammedan or Hindu pious, religious, charitable or beneficial purposes" (Mohammedan and Hindu Endowments 1905, 222). The Ordinance allowed the Governor of the Straits Settlements to appoint a Board in each Settlement "to administer, manage and superintend the endowments" (Mohammedan and Hindu Endowments 1905, 223). Under the Ordinance was a corporation, which was called the Mohammedan and Hindu Endowments Board. The Board was given the authority to administer religious trusts and to manage the Hindu temples and mosques that were vested under the Board in the Straits Settlements (Sinha 2011, 84).

However, Sinha (2011) argues that the implementation of the Mohammedan and Hindu Endowments Ordinance was a watershed moment for the British to intervene in religious matters related to the Hindus and Muslims. The request by the Muslim and Hindu leaders gave the British colonial government an opportunity to implement the Ordinance, which 
rationalised their encroachment into the management of these temples. Sinha $(2011,92)$ further argues that the Hindu communities' role in the Board that was aimed to 'assist' were not consulted during the formation of the Board. The Ordinance had also effectively sliced off the autonomy of the management of these temples from the founders, trustees or appointed committees (Sinha 2011, 84). It is worth noting that such encroachment by the British is not new. When the British colonised India, they had already found Hindu temples to be useful in challenging the Indian king's ancient legitimacy in the region (Mukund 2005, $97 \& 172)$. According to Mubayi $(2005,152,154,187 \& 192)$, the colonial government managed to take over the state and gained political power over the community by taking control of the temple management. Hence, the British were already familiar with using laws in managing the socio-cultural and religious matters of colonised countries (Sinha 2011, 97). The requests from the Muslim and Hindu leaders in Malaya allowed the British to argue that their interference had been legitimate. The Board enabled the British to ensure that temples and endowments were well managed as a means of attracting more Indian merchants to the Straits Settlements while retaining those who were already there. As these Indian merchants continued to settle in the Straits Settlements, the British continued to gain profit from their investments. Since its establishment, the Hindu Endowment Board has administered and managed five Agamic Hindu temples in Penang. 16

Ever since Malaya obtained Independence, the Hindu Endowment Board (HEB) has remained active in Penang and Singapore. When the DAP succeeded in taking over the state government of Penang after the election, they have also taken over the management of the PHEB. Ramasamy, the DAP's representative of the Indian Hindu communities and the second Chief Minister of Penang, is also chairman of the PHEB. In Malaysia, although the PHEB is a statutory body that still stands, it is not necessarily an avenue for the Indian Hindus to seek help on matters related to their community temples being situated on private lands. On the contrary, according to the executive director of the PHEB, M Ramachandran, he was quoted as saying that the PHEB has to date not decided to accept

\footnotetext{
16 These temples are Kuil Arulmigu Balathandayuthapani and Arulmigu Sree Ganeshar, Waterfall Road; Kuil Sri Maha Mariamman, Queen Street; Kuil Sri Ramar, Solok York; Kuil Sree Maha Mariamman, Tokong Lane, Butterworth; Kuil Sri Kunj Bihari, Penang Road; and Kuil Sri Selva Vinayagar Hindu Paripalana Devasthanam, Prai.
} 
any of the voluntary hand-overs of temple and assets offered by the many temple management committees (Ngui 2015). This implies that the Board would only select the temples of their preferences to be vested under the Board. It was not until recent years that the PHEB has successfully persuaded the managing committees of two other Hindu temples to have their management administered by the PHEB. ${ }^{17}$ Indian Hindus from the upper and middle classes also manage these two new temples. Hence, the Board is considered as an elite bourgeois club for the upper and middle classes of Indian Hindus in Penang. The Indian Hindus from the lower and working classes are then left to fend for their own community Hindu temples when these structures are confronted with threats of demolition by the government.

By claiming the PHEB as an elite bourgeois club, however, I do not suggest that the management committee of lineage temples or those managed by upper-class Indian Hindus desire to have their community temples registered under the Board. Furthermore, the PHEB has a reputation for being a government body that seeks autonomous control in the management of Hindu temples. For instance, a recent news article reported that the management committee of Kuil Sri Selva Vinayagar Hindu Paripalana Devasthanam in Prai claimed that they wanted the Board to return the management of the temple to the committee (The Star Online 2016). The former management committee later filed an injunction against the latter, which prevented the Board from participating in the management of the temple (R. Sekaran 2018).

With the PHEB being an elite bourgeois club, the Hindu communities of the illegal Hindu temples have the option of not having their community temples vested under the Board. Moreover, many Indian Hindus are still wary that the Board may take over the management of their temples (Ngui 2015; Lian and Appudurai 2011; FMT News 2015). In fact, in the case study in which the DAP had successfully negotiated with the developer in allocating a new space for the management committee to rebuild the temple (in Chapter Six), the DAP politicians through the PHEB had tried to argue for the temple to be vested

17 These temples are Kuil Arulmigu Balathandayuthapani, Batu Kawan, and Kuil Thropathi Amman, Nibong Tebal. 
under the Board but was refused firmly by the management committee. The chairman explained, "If the [DAP] government want the land to go to HEB, we [the management committee] say, the land you keep. Everything that has to do with the temple belongs to us. We do not want to talk about that. Just cut to that." The firm decision given by the management committee reflected their insistence on protecting their autonomous management of the temple from the encroachment of the PHEB. Their willingness to give up the possibilities of land ownership for the temple also reflected their deep sense of distrust for the Board. Hence, despite popular belief, the PHEB is the least helpful channel that the DAP-led government can use in resolving the issue of illegal Hindu temples in Penang.

\subsection{Conclusion}

In this chapter, I have discussed the significance of political and social contexts of Penang as the research setting for this thesis. The geographical, historical, political and economic situations in Penang indicate how the illegal Hindu temples in the state have been facing multifaceted threats of demolition. However, due to the change of the state government to DAP, I contend that the communities could have leeway in negotiating with the new state government as a way of saving their temples from permanent destruction. I have identified that the communities' leeway for negotiation is constituted by the constraints faced by the DAP-led government. The constraints of the DAP encompass its political principles and its opposition to the BN government. Hence, as the DAP could not employ the similar method of the BN government by destroying these temples, they have instead chosen to relocate these temples. Relocating these temples could also be a challenge for the DAP-led state government since it has limited control over usable lands in Penang. Their limitation over

the usable lands in Penang is historically rooted, which has made it difficult for the DAP to take over these lands for their developmental plan. As a result, the Hindu temples, especially those that belonged to the limited state government would have to make way for new development.

In the following chapters, I turn to an analysis of the three case studies. I examine the experiences of these three groups of Indian Hindus who have gone through the process of 
having their community temples demolished. Then, I investigate the reasons as to why the Indian Hindus chose to conform and comply with the government's proposal in demolishing their community temples. What are the sacrifices involved in their conformity and compliance? What would they gain in return? What are the significances of these Hindu temples to the community that makes them willing to have them demolished by the state government? To answer these questions, I will begin with the case study of a Hindu estate temple in the following chapter. 



\section{The temple in the estate}

In the following three chapters, I turn to the three case studies of demolished Hindu temples in Penang. I examine the indirect and subtle approaches that the Indian Hindus of these case studies have employed in manoeuvring their ways through the DAP-led state government. I examine the social and political contexts which influence their approaches to conformity and compliance to the government. Subsequently, I analyse the indirect and subtle approaches that they employ to safeguard their community Hindu temples from being permanently destroyed. I also investigate the political and social significances of these Hindu temples. I ask: How do these three groups of Indian Hindu communities protect and retain the significance and sacredness of their community temples despite complying with the government's request for the demolition of their community Hindu temples?

The first case study is the demolition and relocation of an estate community temple. The Hindu community from the estate claimed that the Indian labourers established the temple during the colonial period. Prior to the demolition, the land on which the temple had been situated had belonged to the state government. The state government had informed the community that the temple would be demolished in 2013. Following the demolition, the management committee had relocated the statues of the deities into a temporary building that is located about 200 metres away from the previous location. The state government had built the temporary building with the initial arrangement of keeping the statues there for two years. The government had promised the management committee as well as the Indian Hindus from the estate that once a new location is secured, it would be given to them to rebuild the temple. The government had also mentioned that while waiting for the arrangement of the new location, the management committee and the Indian Hindu community could perform their prayers at the temporary temple. With this, the management committee had agreed to the state government's arrangement on the temple demolition. The statues of the deities were placed in the temporary temples. 
In this chapter, I argue that for the demolition and relocation processes of a Hindu temple to proceed peacefully, the management committee has to acquire the cooperation and conformity of the Hindu community that the temple serves. I demonstrate how the demolition brought to the surface the underlying frictions between the management committee and members of the community, as the community objected to the demolition. The frictions between the management committee and the local estate Hindu community have revealed the significance of the demolition of this estate Hindu temple in the political rivalries between the DAP state government and the BN federal government. The political significance of this case further suggests the compliance of the management committee as their pragmatic tactic to ensure the DAP-led state government allocate a new location for them to rebuild the temple. In particular, I demonstrate how the management committee and the Hindu community from the estate temple had adopted the strategy of "playing fool to catch the wise" (Scott 1990), as they waited to see whether the state government would indeed allocate a new location for their community temple. While they waited, they appear ready to give support for the BN government if the DAP-led state government did not allocate a new location for them to rebuild the temple. This case study is also important to demonstrate how the Malaysian political situation is fundamental for the Hindu temple demolition cases in Penang, particularly with the DAP that has taken over the governance of the state. This case study is also important to demonstrate the infrapolitics at the local level by the estate Hindu community. According to Scott $(1990,19)$, infrapolitics are "a wide variety of low-profile forms of resistance that dare not speak in their own name". The variety of low-profile forms of resistance demonstrated by the local Hindu community in this case include bad-mouthing and desertion. I analyse the disguises, development and relationships of their infrapolitics and their appearance of conformity and compliance.

This case study is also important to demonstrate that a Hindu temple as a sacred place is portable. The former location of the temple could also be turned into a mundane place. According to Atran and Axelrod (2008), any credible offers to relocate or rebuild destroyed infrastructures which are imbued with sacred value would backfire. I investigate the expressions of discontentment by those members of the Hindu community who objected to the demolition and relocation. My investigation includes their desertion of the temporary 
temple, their accounts of the incident of demolition and their descriptions about the sacredness of their community temples. The expressions of discontentment from the members of the Hindu community have indicated their important roles in establishing and maintaining the sacredness and the significance of the temple as the source of social influence of the management committee. Based on their expressions of discontentment, I argue that members of the estate Hindu community were willing for the temple to be demolished and relocated. Their discontentment was not because the former location of their community temple would be used for a landfill site for the state. Rather, they were discontented with the management committee for agreeing with the demolition and relocation of temple before a new location is identified for rebuilding the temple.

I begin this chapter with my analysis of the historical narratives of this estate temple and its previous incidents of demolition and relocation. Indeed, it is noteworthy that this temple was demolished and relocated before by the previous Gerakan-led state government with the similar reason that it was located on the state government's land. My

analysis shows that the previous compliance of the management committee was pragmatic, as the previous state government had allocated a new location to rebuild the temple. Then, I investigate the process of demolition and relocation of the temple to comprehend the existing frictions between the management committee and members of the estate Hindu community that surfaced from their accounts. Specifically, I examine how the management committee and the members of the estate Hindu community compared the previous and current incidents of demolition and relocation. Subsequently, I examine how the management committee and members of the estate Hindu community have manipulated the political rivalries between the DAP and the BN for their different purposes. After that, I analyse the sacredness of the demolished and relocated Hindu temple.

\subsection{Historical narratives and previous events of the temple}

Based on the reported cases of Hindu temples demolition in the media, the affected Hindu communities often claimed that their temples were more than a century old. The centuryold legacy claim has been one of their justifications for the government to consider in the preservation of their community temple, rather than having it demolished. The 
management committee and the community of this estate had also made similar claims about their demolished community temple being more than a century old. Nevertheless, despite their claims of a century-old legacy of the temple, the management committee and the community appeared to have repeated experiences of their temple being demolished and relocated. This section is important to demonstrate that the sacredness of a Hindu community requires on-going efforts of establishment and maintenance. It is important to note that the way that the management committee establishes the sacredness of the temple after the demolition and relocation. Specifically, as it is apparent from their historical narratives of the temple, the sacredness of the temple is maintained as it has remained communally significant for the local Hindu community despite the shifting of the temple from one place to another.

I begin this section by analysing the way they narrated the historical background of the temple and making it convincing for the outsiders, especially the government. It is also noteworthy that this temple was relocated before, by the former state government led by the Gerakan party. Their experiences in dealing with the former Gerakan-led state government on the relocation had influenced the way they dealt with the DAP-led state government when they were told of the second relocation. These previous events are contexts in analysing the way the community and management committee dealt with the DAP-led state government. This is because these contexts projected the dynamic and complex power relations that existed between the government, the management committee and the members of the estate Hindu community. Hence, I will also investigate the communities' accounts of the previous incidents of demolition and relocation. How they have related these previous incidents with their current experiences?

During my fieldwork, many of the community members and the management committee have referred me to Muthu, a former chairman of the temple. "The temple was established about 200 years ago. Then the white people [the European planters] relocated the temple to that place [the current landfill site]. The community continued to pray at that temple for a very long time. I know, because I'd started going to that temple when I was about five 
years old." ${ }^{1}$ Such historical background of the temple had indicated that the temple before it was relocated, was imbued with generational memories and rootedness that make it a sacred place (Mazumdar and Mazumdar 1993). Nevertheless, after the British left Malaya, an Indian had purchased the land and had decided to let the temple and the burial ground to remain at their respective locations. The estate community had even elected the new landowner as the chairman of the temple. His daughter inherited the land after the chairman had passed on. Due to the price increase of the land, his daughter had sold the land to a Chinese buyer, who then sold it to the Penang State Municipal Council. ${ }^{2}$ The Municipal Council then sold the land to the PDC (Penang Development Corporation, an agency of the Penang state government). When the state government had decided to relocate the landfill to the affected site in 2001, the management committee had accepted the PDC's proposal in relocating the temple to a place that is closer to the community. Muthu's narratives about the establishment of the temple and the subsequent change of land ownership could be an example of how a Hindu temple built for the Hindu labourers in the estate had been deemed illegally situated on private or government land. Moreover, the willingness of the Hindu community to relocate the temple from one place to another also suggests that the Hindu temple as a sacred place is portable.

Although Muthu could be right in saying that the European planters had built the temple for the labourers, neither he nor the management committee had any documentation to prove their historical claims. Consequently, as the land continued to change hands and

\footnotetext{
1 Verbatim trascript: Dekat 200 tahun kat tempat, itu lama punya. Itu masa tu orang sembahyangsembahyang, habis tu orang putih kasi tukar mari sini. Habis tu tokong sana pun sembahyang lama. Saya tau sebab masa saya kecik, umur lima tahun ini macam sudah pergi [tokong itu].

${ }^{2}$ Verbatim trascript: Pasai dulu orang sudah stay sini. Pasai sana, dulu ada stay sana. Itu jam saya tak ada beranak, bapa saya pun belum beranak. Dulu dia mula bikin orang putih sana, Semua kayu balak punya tempat sana. Itu jam bikin punya lah, kubur pun tak ada sini, kubur tu dia kasi dalam sana. Pasai sana dia kasi punya pasal. Lama-lama itu orang semua pindah sini kan? Tahun 1910 itu jam dia pindah ke sini kan. Macam saya cerita lah itu jam saya belum beranak. Habis tu sudah pindah sini, dia kasi kubur sini. Itu lama punya tokong kan, belakang. Itu tokong dulu ada dua hektar. Kebun punya orang putih sudah kasi. Tapi itu kebun ada orang India punya tanah empat hektar. Satu kali sudah naik harga. Tapi itu Indian dia jadi pengerusi tokong sana. Itu pengerusi kata tak payah pecah lah. Saya sudah tau ini kebun dua hektar tokong punya. Tak payah lu ukur-ukur tau mau pecah. Lama-lama dia sudah mati. Sini punya orang pun sudah percaya, itu perempuan, dia punya anak besar perempuan sudah kahwin kan. Dia punya hati, dia pun sudah tengok kebun ni tak potong, nama juga ada. Dia pergi angkat lawyer, ini kubur bukan estate, saya punya tanah. Lepas tu dia pun cari India sudah jual tanah itu kepada Cina, dia sudah pi. Sekarang itu kubur sudah jadi dia punya enam hektar jadi dia punya. Macam itu juga. Tapi itu betui-betui kasi orang bikin dua hektar. Pasai itu tokong ada belakang kan? Kubur. Dia kasi itu macam.
} 
eventually when the former state government had identified the location as being a suitable plot for the state's sanitary landfill, the management committee was duly informed that the temple had to be relocated. Furthermore, since the government had made plans on expanding the landfill, the DAP-led state government had once again requested the relocation of the temple. Muthu's story has revealed the importance of a Hindu temple having a land entitlement in which it is situated on, irrespective of its possibility of having a century-old legacy. It has also revealed how the government's relocation of the place of worship could only be a temporary solution if they had not given the land entitlement to the temple. Moreover, Muthu's story has also indicated his attempt at highlighting how the temple is important for the estate community for generations. By inserting his childhood memories in the narratives, it could be his way of convincing the outsiders that his story is real.

The consequence of not having formal documentation on the establishment of the temple was seen from the diverse historical accounts in the narratives of the participants. For instance, according to Pavalan, a current member of the management committee, the land from the previous temple location is currently the landfill site for the state. According to him, the previous site had belonged to Guthrie's palm oil company. The Guthrie Company was one of the largest rubber estate companies in Malaya during the rubber boom period, starting from the late 19th century to the 1920s (Tully 2011, 241). Pavalan claimed that all the estate labourers had worked for Guthrie's. "Guthrie allowed the workers to build the temple. But, the workers don't own the land, Guthrie only allowed them to build [the] temple here." Apparently, due to the landfill project in Penang, the state government had bought a portion of the land from Guthrie Company, which had included the plot of which the temple was situated on. Hence, the temple had to make way for the landfill project. "If I am not mistaken the relocation happened in 1982."3 Pavalan's account was different from Muthu's. However, there is a similarity in the gist of their narratives. It is apparent that

\footnotetext{
${ }^{3}$ Verbatim transcript: That belongs the Guthrie land, Guthrie given, because here is all the time the land belonged to Guthrie. The workers are all Guthrie. Guthrie give priority the workers to come out with the temple, given the plans for them. But given only, but not with any agreement not given the land to the temple. They are using for the temple. Not the land do not belong to the temple, but ask for the land to be used for the temple only ... That's why the second place, the temple come here, if I am not mistaken it was 1982.
} 
both were highlighting the importance of their community temple based on the history of its establishment during the colonial period. Pavalan's account further implied a peaceful relocation, especially when he mentioned that the temple committee had no ownership on the land, and therefore had willingly complied with the former state government's arrangement of the move.

According to Pavalan's account, the management committee's compliance was pragmatic, rational and was for the convenience of the community, since the temple could be relocated closer to where they were staying. His claim indicated that the demolition and relocation processes of the temple were smooth and successful. He also implied that the management committee had willingly complied to the relocation. In return, apart from rebuilding the temple, the state government had also offered to compensate the management committee with a monetary sum of RM47,000 (approximately NZD15,700). However, according to Pavalan, “The committee doesn't want to accept the money because it comes with onemonth notice ... Once we receive the money, the temple must be removed from the place in one month." The refusal of the management committee in accepting the monetary compensation has hinted of a crack in their apparent compliance to the former state government. It suggested how they were careful with the agreement made with the government. This level of cautiousness also implies that although they had complied with the government's proposal in relocating the temple, there was an underlying distrust from the management committee. Furthermore, Pavalan has also pointed out that the estate community members had unanimously agreed to their decision of complying with the relocation.

Nevertheless, another member of the community, Jayabalan, had a different and contradictory account concerning the relocations of the temple. He explained, "In 1995, the BN government wanted to take over the land for a landfill. They asked us, 'Can we make a landfill here?' Suddenly, the state government issued a letter, which said that they would demolish the temple. This happened around the year 2000. When the government said that they would demolish the temple, the community did not agree. We cannot demolish the temple because it has been there for a long time. Then, the state government compensated 
the temple with RM65,000 [approximately NZD21,700]. We did not accept."4 Jayabalan's description had depicted the threats he encountered from the previous relocation, which was initiated by the former Gerakan-led state government. He has also implied that although the members of the estate community had disagreed with the relocation, the government had suddenly gone ahead with the temple demolition. The former management committee's decision on not accepting the monetary compensation offered was to demonstrate their rejection of the relocation. Above all, the community's sense of threats that Jayabalan claimed they have been experiencing is missing from Pavalan's account. Jayabalan explained the differences, "The one[s] who held positions of the management committee in the temple passed away; then new people resumed the positions. These people registered the temple as a formal form of organisation, such as an NGO. Last time the temple was an 'association', not anybody can access the money for the temple. But they [the new management committee] changed it into an organisation, means that they can easily access the money." ${ }^{5}$ Hence, the previous relocation of the temple was due to the betrayal by the current management committee. This also implied that the relocation of the temple by the former state government had not been as peaceful as Pavalan had described it to be. Since then, the conflicts as a result of the betrayal have persisted and continued up to the recent temple demolition issue by the DAP-led state government.

The news on the DAP-led state government's plan in expanding the sanitary landfill of Penang was reported in 2013. As part of the expansion project, the state government had planned on moving the estate community. This also meant the estate's Tamil primary

\footnotetext{
4 Translated from: Pada tahun 1995, kerajaan BN (Barisan Nasional) mengambil tanah melumpuh sampah sisa, buat cadangan wa lumpuh sini boleh kah? Tiba-tiba kerajaan negeri sudah keluar satu surat, dia kata itu temple akan diroboh. Tahun 2000, dia kata dia mau roboh. Bila dia kata dia mau roboh tokong itu, penduduk tidak bersetuju. Kita tak boleh roboh tokong ini, sebab itu temple sudah lama ada di situ. Habis tu dia bagi pampasan kepada temple itu sebanyak RM65,000. Kami tak terima. Jayabalan's family has been staying in the Byram estate for at least three generations. "Last tahun 1958, wa punya kakak sudah mati, kita sudah buat. Ayah saya sudah buat..." (Translation: In 1958, my elder sister passed away, and we buried her there. My father did it).

${ }^{5}$ Translated from: Siapa yang memegang jawatankuasa tu, telah meninggal. Baru yang pegang tu dia dulu tu mengikut pertubuhan Sri Maha Kaliamman, name dia. Bila sudah mai pengerusi baru, dia buat pertubuhan, NGO macam, pertubuhan persatuan. Sekarang pertubuhan banyak orang boleh buat apa, dia buat saya pun boleh buat. Dulu pertubuhan Sri Maha Kaliamman. It's a temple name. Nobody can take the money or whatever also cannot. Now pertubuhan. Anybody can also take the money already.
} 
school and the temple, the key features of an estate settlement, would also be demolished. The community became acutely aware of the implication from the state government's landfill expansion plan when the government evicted seventeen houses as the first phase of the expansion plan. I managed to find a YouTube video describing the evacuation of the seventeen houses. The video showed the affected household members holding the notice of eviction that was dated 18 December 2013 (APT Youtube Channel 2013, https://www.youtube.com/watch?v=M-L0UpGr3hI). Another member flaunted a letter by the local Council of Penang asking the affected seventeen households to move into the flat units that were located out of the estate's vicinity. A member of the affected households said that the people had refused to leave the estate where they had been living most of their lives (APT Youtube Channel 2013). Hence, the seventeen families had tried to negotiate with the DAP-led state government through a series of meetings (APT Youtube Channel 2013). Nonetheless, the community still received the letter of eviction with a monetary compensation of RM2,000 (approximately NZD670) for each household. The video had particularly focused on the distressed community who had refused to leave the estate. I have met with an affected household that chose to remain in the estate, "If we all relocated to Jawi [another town] after school (how are the children) to go back there [Jawi]? Those who work here, how are they supposed to travel to this estate? Cannot. They said they will give us the bond for rental. But we still have to pay RM100 rent. That's not right."6 Their explanation has revealed how the eviction would be disrupting their lives in the estate and bringing discontentment among the community members.

The APT Channel, which published the video clip on Youtube is a channel formed by UMNO (United Malays National Organisation, a founding political party of the BN coalition). The particular emphasis on the distressed community is a political move in showing how the DAP-led state government was intimidating the daily lives of the estate community. It is apparent that this matter would give the UMNO politicians an opportunity in challenging the DAP's political principle of 'Malaysian Malaysia' that promotes and aims to secure the

\footnotetext{
${ }^{6}$ Translated from: Kalau dia orang pi Jawi sekali, itu sekolah semua mau lepas balik ke sana? Kerja sini, boleh mari ke sampai sini? Tak boleh. Itu pun dia bagi bond semua free. Lepas bond habis you kena bayar RM100 satu bulan sewa. Mana betui, tak ada betui.
} 
special and legitimate interests of different communities within the framework of collective rights, interests and responsibilities of all races. It also revealed how the DAP's landfill expansion project had attracted the watchful eyes of BN politicians. Therefore, the DAP had to take heed on the way they handle the matter concerning the demolition and relocation of the estate temple. The evacuation of the seventeen households had certainly added another layer of complexity to this case due to the discontentment of the community. In the next section, I turn to the demolition and relocation processes of this temple.

\subsection{The process of demolition and relocation of the temple}

With the seventeen households being moved out from the estate as a result of the relocation, the remaining households were left with feelings of discontentment. Soon after, these remaining households received news that the management committee of their community temple had agreed for the DAP-led state government to demolish their community temple. As a result, the agreement made between the management committee and the DAP-led state government had caused frictions between the former with members of the discontented estate Hindu community. Friedland and Hecht (1991) could be right that the conflict between different communities is a catalyst for the formation of a sacred place. In this case, however, the conflict is between not only the estate Hindu community and the state government. The tension between the management committee and the local Hindu community has also galvanised their deep emotions and attachments to the temple. Hence, I argue that the demolition and relocation of the temple has, indeed, accentuated the sacredness of the temple. However, it is by no means that the temple as a sacred place is not portable. The resentment of the Hindu community stems from their distrust of the management committee and not because of the demolition of their community temple. In the following sections, I analyse the tensions between the management committee and members of the Hindu community due to the demolition and relocation of the temple. I begin in this section by investigating the willingness of the management committee for the demolition as being part of their tactical and pragmatic strategies in ensuring that their community temple could be relocated elsewhere. My analysis is based on their narratives with regards to the demolition process. I ask: how effective is this tactic of complying with the demolition of their community temple in safeguarding the future of their community 
temple? What are the implications from their willingness in having their community temple demolished by the government, particularly regarding the frictions that existed between them and the estate community members? I found the answers to these questions through the accounts from the participants of the management committee.

The announcement to demolish and relocate the temple came six months after the eviction of the seventeen households, while many members of the community were still experiencing anxiety and a sense of loss. A convoy of state government representatives came to Byram Estate. My participants reported that the convoy consisted of the Second Deputy Chief Minister of Penang, P Ramasamy; state assemblyman, Phee Boon Poh, who is also a State Exco (Executive Council member) for the Welfare Caring Society, Health and Environment; and State Assemblyman Law Choo Kiang. Many participants from this case recalled how the management committee had organised the arrival of the representatives to the estate. The management committee had called for members of the community to assemble at the temple. According to Pavalan, “... they came and talked to the people, promised they would find a land for the Tamil school over here, one housing project. From there we agree to come, to relocate the temple to this place ... We agree that here is just temporary for two years. After that, they [the state government] wants to find land for permanent." As a result, the management committee of the temple had agreed to the relocation of the temple precisely because of the promise made by the state government, while the estate community had intended on retaining the estate settlement that had been set up by the European planters during the 19th century.

For the DAP-led state government to make a promise of relocating not only the estate community but also the whole estate settlement has reflected how they are aware of the significance of the settlement for the community. Furthermore, the promise of a permanent place would indeed offer security for the future of the temple, which could diminish any impending threats of demolition on the temple. For these reasons, the management committee had willingly complied with the government's proposal of relocating the statues of the deities into a temporary building and in the demolition of the temple. It is also apparent that the DAP-led state government had made an ambitious promise to the 
community, as the relocation involved not only the temple but also the whole community and the affected school. With their limited access to the usable land in the state, the state government appeared to have set a difficult task upon themselves.

Despite the difficulties of finding a new location for the estate Hindu community to rebuild the temple, the interpersonal approach of the state government had demonstrated their assurance that they would succeed in delivering what have been promised. The way they met with the community members and the giving-out of hampers had indeed been different from the way of the BN-led government in sending eviction notices to the management committee without any prior negotiations. However, the incentive offered by the state government appeared to have a less-than-anticipated effect. One of the community members, Bala, believed that the state government's proposal did not make sense. "If they want to take the place and want to relocate [the temple], they should first look for a place for us. When they have found a place, then we relocate. Now they just put the temple there and said that they [the state government] would find a place, then they will relocate the temple. In two years, the [temporary] temple has to be there for two years." ${ }^{7}$ The reason given by the state government for the early demolition of the temple is to make way of the landfill expansion plan. It is noteworthy that the government has also given the similar reason for the eviction of seventeen households. However, a year and a half later, the remnants of the demolished temple and the vacated seventeen houses were still seen on the current sites.

The remaining ruins gave an impression that there is no sense of urgency for the DAP-led state government to use the leftover spaces. Hence, the community had regarded the early demolition of the temple (including the seventeen households) and the relocation of the deities to the temporary site to be unnecessary. The community further believed that the early demolition is an act of discrimination by the DAP-led state government. Bala said, "Now the temple is left like that at that place. They demolished it around 2014 to 2015,

\footnotetext{
7 Translated from: Kalau dia mau ambik, patutkah mau ambik, mau pindah lah mau cari satu tempat satu bagi dulu. Ada tempat baru mau pindah tokong ini. Tapi temporary dia bikin extra dua tahun, tokong itu angkat pi orang punya sana, bila ada tempat saya bikin kasi. Sekarang macam ini, sekarang itu tempat, campon punya dia bagi dua tahun, dua tahun juga dia bagi dua tahun.
} 
after 2016, where will the temple go?"8 As Bala who is sixty-six years old, is born and bred in the estate, his expression of helplessness further reinforced the sense of being discriminated against.

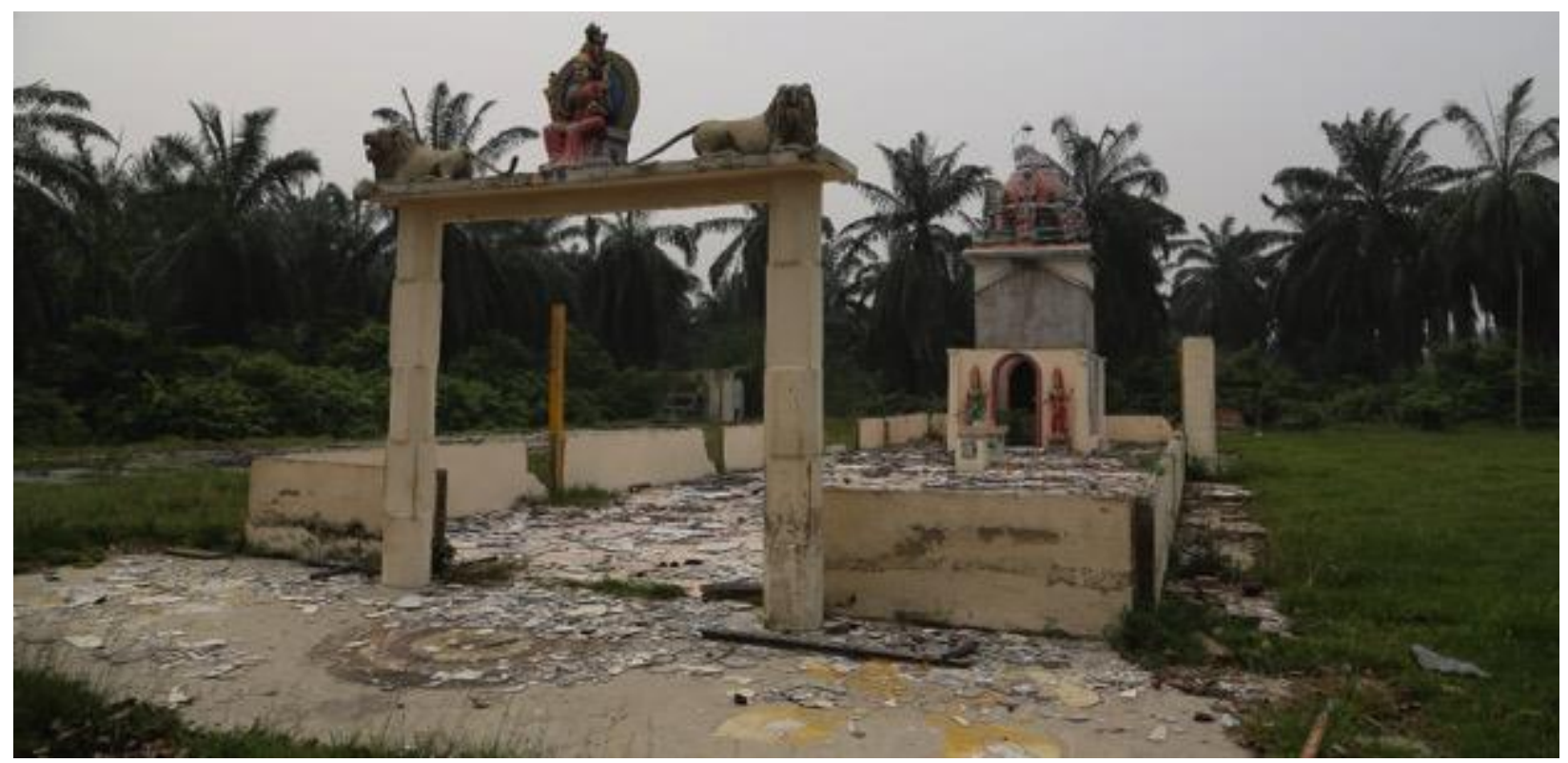

Figure 2 The Demolished Kaliamman TEMPle in The ESTATE (Photo taken DURING FiELDWORK)

The management committee has been aware of the objections from the community. Pavalan said, "The people (members of the community) are very against our decision [to let the state government demolish the temple]. They asked, 'Why wait two years, you want to relocate the temple, why not you find the land for the temple first, the government only have to find one acre of land, it is easier than to find 500 hectares of land to expand the landfill. Find the land first, then we can move.' They all against." As they have chosen to ignore the community's point of view, Pavalan further said, “... but we, the temple committee, willing to take the responsibilities and cooperate with the state government. But we also know that if the state government does not fulfil their promise, we are the ones who have to face the community." This presumption of an autonomous decision-making power has also revealed the way Pavalan perceived the management committee as having control over the community temple. Although Pavalan later lamented, "You know my

\footnotetext{
8 Translated from: Sekarang macam ini, sekarang itu tempat ... 2014 to 2015 itu masa dia sudah buat. 2016 mana mau pi taruh itu tokong?
} 
situation, this is not easy work, you know," there is still an obvious connotation that the management committee believed the community's opinion on the matter have been secondary. This has demonstrated that the management committee would be at the forefront of negotiation in ensuring that the state government is being held accountable to the agreement that has been made between them.

As Pavalan appeared to be willing to take the responsibility for their temple, I asked him if he was confident that the state government would be able to find a place for them to rebuild the temple and relocate the community. He admitted to the task difficulty faced by the state government: "...because the process of acquiring a land takes time. I heard some landowners do not agree with the offers of the state government. They [the state government] will need more time, not just two years because the acquired land is very big." Due to the above difficult issues, it was possible that the state government would not be able to relocate the temple to a permanent site within a two-year period. The way that Pavalan had repeatedly been pointing out the delays by the state government further reflected his doubts. He even said, “One year pass[ed] already, another left one year. Don't know if the acquire [of the land] is done or completed or not, they said if once the acquisition complete, then PDC want to plan." However, he still indicated that the management committee would still conform to the state government's proposal on relocating the temple willingly, as though the former had not been affected by the discontentment of the community.

Nonetheless, not all members of the management committee shared Pavalan's optimism of the state government would find a new location for them to rebuild their community temple. They had even been sceptical of the government's promise on getting a new location in two-years time. According to one of the members, Mani, it would not be difficult for the state government to allocate a place for the temple. The delay has been mainly due to the negligent attitude of the DAP-led state government following the demolition of their temple. "They [the state government] promised to build a new one [for us]. But, until now, 
nothing is done. What can we do? They [the state government] also don't like us."9 According to Mani, the reason that the DAP-led state government had low regard for them was that of the temple's management committee's political affiliation with the BN coalition. Mani said, "Last time we were all JKKK (an acronym for Jawatankuasa Kemajuan and Keselamatan Kampung, also known as the Village Security and Development Committee) for the [BN] government."10 11 A study by Scott $(2008,131)$ had found that being members of the political party that is an ally to the BN government often brings substantial benefits for the villagers. In this case, too, as indicated by Mani, their close association with the BN government had apparently enabled them to safeguard their community temple. At the same time, Mani's response also indicates that the social positions of the management committee of this temple had been relying heavily on the "borrowed" resources from the political dominance of the BN government. Scott $(2008,137)$ argues, however, as the management committee relies on the political influence of the BN government rather than patrons of their own rights, their social positions as management committee have also become increasingly vulnerable. This is because their fate has been intertwined with the the political performance of the BN government.

This is evident after DAP's win on the state, the members of the management committee had left their positions and joined the JKKP, a federal counterpart of JKKK. ${ }^{12}$ " ... sometimes we are invited by UMNO people to attend the meeting for the JKKP. If we go to their meetings, they will give us RM50.00 [approximately NZD16]. They will ask us what they can do to help the community. We will tell them what kind of help we want from them and

\footnotetext{
${ }^{9}$ Translated from: Dia orang janji nak buat baru. Tapi sekarang apa pun tak ada bikin. Apa mau bikin. Dia orang pun tak ada suka kita ... Itu pasal itu, kita pun tak boleh bikin apa.

10 Translated from: dia orang semua DAP punya kita pun mau bikin. Kita pun ada cakap. Dulu semua ini semua orang JKKK itu government punya kita pun ada bikin.

${ }^{11} \mathrm{JKKK}$ is a community-based organisation at village level. It is one of the federal government's initiatives to develop the rural areas of Malaysia. Before March 2008, the structure of JKKK was uniform throughout the country. It comprises 10 to 12 selected members from the community (Ahmad and Silong 2011).

12 After the General Election in 2008, the Federal Minister of Rural and Regional Development encouraged the JKKK of the state, led by opposition Pakatan Rakyat, to resign from their positions. The Minister promised these JKKK that they would receive an allowance from the federal government after their resignation. Subsequently, the Federal Village Security and Development Committee (JKKP) was established. As many of the JKKK committee resigned, the PR state government appointed a new village committee. This resulted in two different sets of village committees (Loh 2010,134).
} 
what the DAP has done to help the community."13 As a result of their continued affiliation with the BN politicians, the management committee believed that the DAP-led state government's negligent attitude could have been politically motivated. Above all, Mani has expressed the management committee as being powerless to the request of having their community temple demolished. "[Now] they are all DAP people ... That's why now we can't do anything." Indeed, Scott (2008), in his previous study, has suggested that the villagers who had been dependent brokers of the dominant groups for higher status would lose out if the dominant group lost their position in the village. Similarly, in this case, as the BN government has lost Penang, the managmeent committee indicated that they had lost the leverage to negotiated with the current DAP-led state government. Mani not only believed that the government would not be able to deliver what have been promised, he even indicated that the demolition is an act of discrimination by the state government, which the management committee is unable to prevent. Since politics has proven to be an important element for this case, I turn to the political rivalry between the BN national government and the DAP-led state government in examining how the rivalry between the two parties is useful for the management committee of this temple.

\footnotetext{
${ }^{13}$ Translated from: kadang-kadang kita tau itu meeting, kita pi mari, meeting pi mari, dia orang bagi RM50 juga. Meeting JKKP punya. Dia tanya apa mau bikin, kita pun mau bikin, dia orang semua DAP punya kita pun mau bikin. Kita pun ada cakap. Dulu semua ini semua orang JKKK itu government punya kita pun ada bikin.
} 


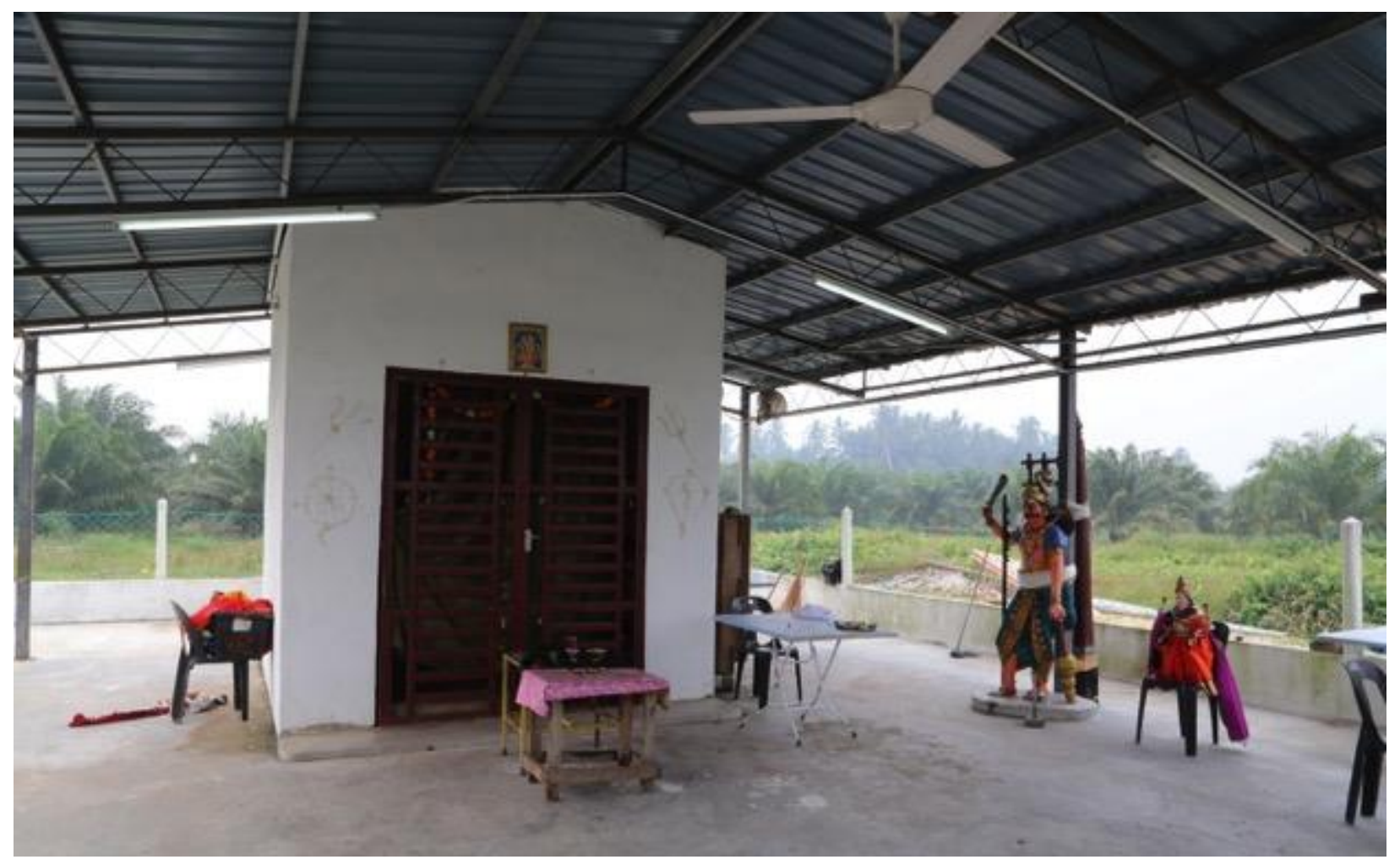

Figure 3 The temporary SRi Kaliamman temple of the estate, Penang (Photo taken during FIELDWORK)

\subsection{Political rivalry between the DAP and the BN government}

The political rivalry that occurred between the DAP and BN has continued to be significant for this case. Scott $(1990,56)$ argues that political rivalry between dominant groups could be a leeway for exploitation by the subordinates for renegotiating the terms of subordination. In this case, both the management committee and the members of the estate Hindu community realised that it could be advantageous for their case. In this section, I analyse how the management committee and the estate Hindu community had manipulated the rivalries between the two governments as a way of holding the state government accountable on the promise made to the permanent land allocation of the temple. The analysis in this section is also to demonstrate how the conformity and compliance of the management committee have been pragmatic and tactical acts.

The political contestation between the DAP and BN has created a political setting in Penang, which the management committee could manipulate to their advantage. Scott 
(1990) argues, "If the dominant are at odds with one another in any substantial way, they are, to the degree, weakened, and subordinates may be able to exploit the divisions and renegotiate the terms of subordination" (56). In this case, one of the elements that constituted the leeway for negotiation for the estate Indian Hindus is the voting power of the Penang people. According to Muthu, "I have my theory. I have [a] feeling that if we want to know what would happen to us, we have to wait for the year 2017 when the next general election is near. When we are about to vote, then only we would know what kind of houses and where would they build these houses for us. Now, the state government will only tell us different stories. We will only know the real story during that particular time."14 Muthu's theory could be right, especially with the insurgent political interests that revolved around Indian voters as demonstrated from the previous two general elections. ${ }^{15}$ Waiting until the election period (the earliest possible time would be 2018) would have been too late for the state government. Nonetheless, it is safe to assume that this case would be useful for the politicians to gain populist votes from the community and the Malaysian electorates. This is because, as mentioned earlier by Mani, many members of the management committee were still being affiliated with the BN right-wing ruling government. The political affiliation of the management committee with the BN government has reflected how the BN politicians have been aware of the way the DAP-led state government in handling this case. The political interests of the BN government have given the management committee leeway for negotiation as well as to ensure the DAP state government's accountability.

Apart from the management committee, some members of the Indian Hindus in the estate also saw the political rivalry as an opportunity in manipulating the political situation by way of asserting pressure on the DAP. Bala said, "During the time of the BN, the Datuk said, this is my place and my people cannot be evicted, not until we have found a new place for the people, then we will ask them to relocate. But now with these new people took over, I

\footnotetext{
14 Translated from: Saya ini cerita saya. Saya punya hati lah. Ini cerita betui-betui mau tau lah, Tahun 2017, hujung baru tau, dekat election. Election mesti cakap. Pangkah itu bikin rumah, rumah bikin mana satu. Mana dia orang mau bikin. Sekarang dia orang cerita, cerita itu lain. Itu jam betui-betui sudah tau punya. 15 I visited the community again in early 2017. According to some members of the community, who include Bala and his wife, and Ranjini, the DAP-led state government has issued monetary compensation for their relocation to Jawi. The compensation for each household is varied, and Bala claimed he could not understand why his family was getting less than many other households. More importantly, they had not heard news about the new location to relocate the temple.
} 
don't know what will happen to us." 16 On the onset, it is interesting to note that the management committee had presumed that the DAP-led state government had an obligation in allocating a new location for them to rebuild the temple because the previous state government had done so. They referred to the previous relocation by the former government as a form of legitimacy given to their community temple. This particular comparison of the previous and current state governments has hinted at how they have been discriminated against by the DAP-led state government. This claim has also discredited the current discourses, which identified the Malay-Muslim led government as the main perpetrator of the on-going Hindu temple demolition issues in Selangor and Kuala Lumpur. Therefore, their hints of possible discrimination could be a subtle pressure in ensuring that the DAP-led state government is being held accountable for the promise made about the temple site allocation.

Bala's emphasis on the previous state assemblyperson that had been more sensible in handling the community temple relocation issue has reflected his discontentment with the DAP. Apparently, he is aware of the current discourses and intended on proving them wrong. It also suggests that he is aware of how the DAP had relied on the non-Malays votes in Penang to win over the state in 2008, which has heightened the party's intent on retaining the political support from the grassroots non-Malays. Therefore, Bala's comparison has indicated a further threat to the DAP-led state government. Bala's wife added, "Sis, let me ask you, why they [the state government] don't disturb that new Malay village over there. They have all gotten a house from the government. The government constructed terrace houses with storeys for the Malays. After they completed the construction, then they asked the people to move in. We, the Tamil, why Ramasamy gave them RM4,000 (approximately NZD1,400), but he never gave us that?"17 Her description on their sense of being intimidated by the DAP state government has revealed how they had

\footnotetext{
16 Translated from: Itu BN punya jam, tak mau keluar sama dia orang. Datuk punya jam, sekarang saya punya jam, saya punya tempat saya punya orang tak boleh buang. Bila ada duduk baru saya orang bikin bagi. Tapi tak tau lah apa jadi.

17 Translated from: Adik saya tanya sama kamu ah. Itu kampung baru orang Melayu punya. Kenapa dia tak pi ganggu sama dia orang. Orang Hindu dia selalu ganggu. Kampung Baru dia pi sana pindah. Satu orang satu rumah, dia orang ada ... Dia buat tingkat punya rumah, dia orang tanya itu rumah. Baru dia orang pindah sana, dia orang jaga. Kita orang orang Tamil, ini Rama, kenapa dia bagi, RM4,000 dia tak bagi kita orang.
} 
intended to turn the tables by utilising the similar criticisms of the Malay Muslim-led government's discrimination against the Malaysian Indian Hindus.

The comparison of administrations between the previous Gerakan-led state government and the current DAP-led state government by Bala and his wife has suggested their discovery on a similar pattern of discrimination by the DAP. The claim from Bala's wife has also indicated that she is aware of how the DAP is criticising the Malay Muslim dominance of the BN national government. Moreover, as mentioned in Chapter Three, the non-Malays' votes had contributed significantly to DAP's victory in obtaining the governance of Penang. Bala and his wife's grievances suggested that they are aware of how the DAP's political reputation and principle have been the party's "public transcript"- a self-portrait of public reputation that is designed to be impressive, to affirm their political power in Penang and possibly to conceal or euphemise the dirty linen of their rule (Scott 1990,18). Therefore, Bala and his wife recognised that they could manipulate the "public transcript" of the DAPled state government for their "artful manipulation of deference" (Scott 1990, 34). They were artfully reinforcing the popular perception of marginalisation and discrimination of Malaysian Indian Hindus as a way of challenging DAP's longstanding political reputation as being a political party that fights for egalitarianism.

While still waiting for information concerning the future of their community temple, the estate Hindu community soon received news about the possible demolition of the estate's Tamil primary school. Pavalan told me during the interview, "A new message came from the Ministry of Education. They received a letter issued by the PDC. The letter was a proposal for the Ministry to close the Tamil primary school. This will also affect the temple and the people here. I don't know if the state government knows about this ..." The news of the Tamil school demolition further echoed the Hindu community's scepticism.

Subsequently, the community's act of submissiveness has also reached a breaking point. As the letter was issued by the PDC, the management committee and the community had not been certain if the state government had already been informed on the said matter. Pavalan was determined to get an answer on the demolition issue from the state government, "Maybe next week I will make an appointment with Professor Ramasamy. I want to discuss 
this matter because this means something is wrong over there. He came here; he promised everything. He promises no problem with the land, and the temple also will have a temple, school, and housing project, everything. He mentioned in the speech. Suddenly we heard this issue. This is very sad news." Pavalan's grievance had demonstrated his sense of being betrayed. Like the temple, the school had also been a part of the estate settlement. With the issue of the temple still yet to be resolved, the demolition of the school has further reinforced the community's doubts and scepticisms. From Pavalan's expression with regards to the news, it appeared that his confidence towards the DAP had wavered.

After the interview with Pavalan, I discovered that the community had sought media attention about the matter of the school. They were reported as saying that they would not let the state government demolish the school without putting up a fight and also demanded proper compensation of a new location and rebuilding of the school before any demolitions can be initiated. Ramasamy did respond through a Tamil daily newspaper that the school was in no danger of demolition and relocation (The Star Online 16 July 2016). However, on 16 July 2016, news about the possible relocation of the school was reported again in the mainstream media. This time the media's focus was on the First Deputy Education Minister, Datuk P Kamalanathan who was quoted as saying that the PDC should have first identified a new location, one which was agreeable to the community in the estate before moving the school (The Star Online 16 July 2016). Kamalanathan is also a member of the MIC (Malaysian Indian Congress) and a Member of Parliament in the state of Selangor. As it appeared, he was delivering his speech in a ceremony to hand over the BN government's RM400,000 (approximately NZD146,000) aid to the school. The report had confirmed the rumours of PDC's proposal on the demolition of the school and its relocation to another site (The Star Online 16 July 2016). Kamalanathan's intervention in the matter has revealed the constant political interest in the relocation of the estate community. More importantly, it would project the discontentment of the community due to their political position in the state if they could not find a new location for rebuilding the temple.

On 28 June 2017, the chairman of the Penang Tamil Schools Special Committee announced that the DAP state government has identified a new location for the school and that 
renovations would commence by the end of the year. However, the report did not mention if the community and the temple would also be relocated near the school, as what DAP had promised DAP. Although it remains debatable if the DAP's willingness in allocating a new place for the school relocation was due to BN's intervention on the matter, I would not dismiss the possibility that the political rivalry between these two governments had some influence in the outcome of the relocation.

The matter of the possible demolition of the school had tested the compliance and conformity thresholds of the community and the management committee. Their proclamation on fighting for their school and the seeking of media attention on the matter have projected their awareness of their political surroundings and the way they were able to react pragmatically according to the current political situation. Hence, although they have shown their compliance, submission and docility, these actions do not necessarily equate them as being submissive or compliant to the matter on hand. On the contrary, the perception of being submissive, docile and powerless has been useful for achieving their purposes, especially when the matter is caught up in the political rivalry between the DAP and BN. In the next section, I turn to the reactions of the community as a means of analysing if their reactions are different or similar to those of the management committee.

\subsection{Reactions of the estate Hindu community towards the demolition of the temple}

The willingness of the management committee to conform and comply might have suggested their submission to the hegemony of the state government. However, as mentioned earlier, their compliance and conformity had heightened the existing tensions that occur between them and the Hindu community members. More important, as I have suggested in Section 4.1 is that the sacredness of this temple is constituted mainly of its communal significance. Despite the repeated demolition and relocation, as the temple has still been accessible for the local Hindu community, it has remained a sacred place. Hence, this section is important to demonstrate that the increasing tensions between the management committee and the local Hindu community have undermined the communal significance of the temple that is required for it to remain sacred. I begin this section by 
analysing how the frictions had become more severe due to the demolition of their community temple. I also investigate the reactions of the Hindu community members to the demolition. My analysis consists their narratives about the day of demolition and their opinions on the state government's plan for relocation.

To start off, the members of the estate Hindu community had given various accounts describing the day of demolition. A participant, Ranjini recalled, "When they demolished the temple, we all cried because we were all angry, didn't want them to demolish the temple. But they forced it. They said it belongs to the government, so must be demolished. A lot of people came out to protest ... sent a lot of letters, but the government rejected all our letters." 18 Jayabalan said, "The chairman said, 'whoever dare, can come forward, we must demolish this temple. We have police here; you dare to come and stop us?' The chairman, with his brothers, was there. Then the police came with the chairman and Ramasamy, and they demolished the temple. All ... they pushed ... pushed ... pushed ... all destroyed. All the heads of the statues [attached to the structure of the temple] were destroyed ... the temple was destroyed..." 19 Ranjini's and Jayabalan's dramatic accounts reflected not only their feeling of being threatened by the state government's act of demolition but also a sense of being betrayed by the management committee. The issue of the management committee disregarding their objection to the demolition and relocation has been mentioned in Jayabalan's account. I found Ranjini's narratives to be similar to the grievances of the seventeen distressed households shown from the Youtube video. The similarity suggested how she was still being affected by the forcible eviction of the households when the state government began demolishing the temple.

While Ranjini and Jayabalan had given dramatic accounts, Muthu had insisted, however, that the demolition on that day had been carried out smoothly. "There was no protest.

\footnotetext{
18 Translated from: Masa dia ambik punya jam semua pun menangis juga. Sebab orang sini pun banyak marah tak mau ambik. Tapi dia orang paksa. Dia orang kata ini kerajaan punya, kena pecah bagi. Banyak orang keluar buat mogok semua tu ... Hantar surat banyak. Semua pun dia orang reject.

19 Translated from: Pengerusi bagi tau siapa berani, mari di situ, kami mesti mau tolak, polis ada semua pun ada, you berani kah tolak, yang baru punya pengerusi adik beradik ada di situ. Bila sudah jadi macam tu di temple itu, tiba-tiba kerajaan polis bawa mari dengan pengerusi, prof, itu semua tolak itu tokong. Tokong itu semua sudah ada, semua tolak ... tolak ... tolak ... semua pecah, kepala semua pecah ... pecah ... pecah itu temple ...
} 
When they [the state government] first wanted to demolish the temple, we did not agree. They [the state government] said they want to demolish, we said cannot. We said, if you want to demolish, you build another one for us ... that's all we ask. They said they want to give us a hall and a field. We insisted on having a school and a temple. They said want to rebuild a school, a hall and a big field, that I don't know." 20 Muthu's refutation on the protests or the dramatic reactions from the community that supposed to have occurred on the day of the demolition appeared to be in line with the compliance and conformity shown by the management committee. As I could not find any news report on the event that took place on that day, I was not able to determine which of the descriptions is true.

Nevertheless, the diverse accounts given by these participants are significant in revealing the tensions that occurred in the estate Hindu community. Although Muthu had denied any occurrences of protests, his contradiction is a way of showing conformity to the state government. This denial is an active political act in portraying the estate Hindu community as subordinated to the hegemony of the DAP state government.

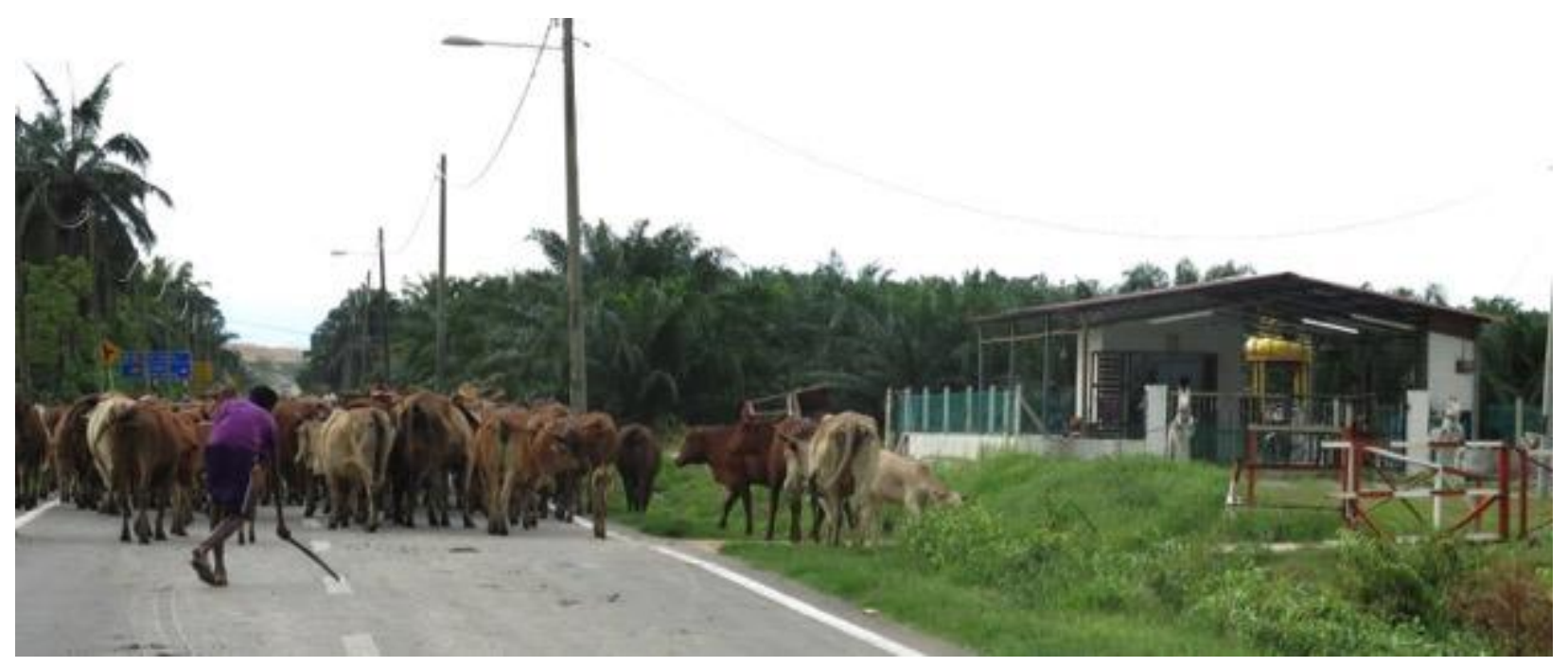

FIGURE 4 THE TEMPORARY STRUCTURE TO HOUSE THE STATUE OF THE GODDESS

\footnotetext{
20 Translated from: Itu jam tak ada mogok. Pasai kita orang mula-mula dia mau kasi pecah, saya orang tak lepas. Dia kata nak pecah, saya orang cakap tak boleh. Ini mau pecah, you kasi satu tokong, you bikin sana kuil satu, estate sampai sekolah. Ini juga saya orang tanya. Kadang-kadang dia cakap satu dewan kasi, padang satu kasi ... dia juga cerita itu. Saya orang tanya sekolah, rumah kuil juga. Dia kata, sekolah kasi, dewan kasi, padang besar kasi, Itu tak tau lah.
} 
The building on the right is the temporary structure to house the statue of the Goddess Kaliamman, which is also a temporary temple for the estate's Hindu community (Photo taken during fieldwork)

The reason for such continuous display of conformity to the state government has been intended on ensuring the state government's accountability. According to Muthu, "Those who don't know politics, they talked and made noise about the issue, they don't know that is useless." ${ }^{21}$ According to Muthu, what is useful is not to interrupt the state government. "The government has already taken over the land; we should not disturb. We ask that the government give us a place, and we will stay quiet. The community should not try to protest. The government thinks that they can do anything. Don't interrupt. The government will give houses and temple. No need to protest. Politics are their business. They have a different intention; it is their problem." 22 Such display of compliance by Muthu suggest his implicit awareness that the DAP-led state government would also make an effort to ensure that the Hindu community would not protest openly against them for demolishing the temple. Scott $(1990,56)$ argues open insubordination represent a dramatic contradiction of the smooth surface of euphemised power. If the Hindu community had protested and caught the attention of the public, the DAP would have to make a public reply to restore their reputation and the status quo of their political positions (Scott 1990, 57). Hence, by complying and conforming to the hegemony of the state government, Muthu believes that the community would stand a better chance of getting the land for relocation. Muthu's opinions stem from his experience of being involved in the politics. "I am fifty-eight years old. Since I was seventeen years old, I had joined politics. All my uncles were also in politics. Last time, there was just the MIC. After the MIC was gone, I joined Gerakan. After that, the DAP came. I give up. It's okay. If the Opposition can do a good job, we support them. If the BN can do a good job, we support them. No need to fight over who has taken

\footnotetext{
${ }^{21}$ Translated from: Tak tau politik punya orang dia orang cakap, keriau-keriau tak guna juga.

${ }^{22}$ Translated from: Ini tanah kerajaan ambik pi, tak boleh kacau. Sekarang kerajaan kata nak bagi satu tempat.Kita duduk diam-diam. Jangan kacau. Dia orang kata nak bagi rumah dan temple. Tak payah keriau. Itu politik dia orang punya pasal. Mereka niat lain, itu dia orang punya pasal.
} 
whose place."23 Muthu's political wisdom indicated that the pragmatic acts of conformity and compliance have the potential to be effective as proven from the temple's first relocation.

Despite Muthu's apparent political wisdom, it is by no means that Muthu was implying that the management committee would be giving their political support to Ramasamy and the DAP-led state government. Instead, he was suggesting that Ramasamy had the choice of standing for election in another constituency, which could even be outside Penang. Muthu also shared a similar concern. He recalled that some members of the community even asked Ramasamy when the representative had a meeting with the community at the temple prior to the demolition. "That day they [members of the community] asked him [Ramsamy], 'Professor, now you have one more year to sit in the position [as the Second Deputy Chief Minister]. But when the next election comes, you might contest in another place, what will happen to this place? Prof, if you run for election here in Penang, it's fine, we can still come and ask you. But what if you go to KL or Johor, then who should we ask?' He [Ramasamy] got mad and said, 'You can't say such a thing.' And left [the matter] just like that."24

Therefore, it becomes apparent that Muthu was anxious about the agreement made on the relocation of the Hindu temple. I found a brief report when Ramasamy had announced the plan of demolishing the Sri Kaliamman temple that was posted on his social media site. In a series of the pictures posted, I saw Muthu among those who attended the event. So I inquired Muthu on the announcement that Ramasamy had made on that particular day. According to Muthu, "Ramasamy said, "The PDC wants to take the plantation and the estate. In a year and a half or two years, I [Ramasamy] will give houses, burial ground, temple, a hall and a school, all in a place. I can give.' But it has already been a year and a half, they

\footnotetext{
23 Translated from: Saya sudah umur 58. Saya sudah politik 17, saya punya uncle semua politik juga dulu. Dulu MIC saja ada. Dulu MIC sudah pecah, masuk Gerakan. Sekarang masuk-masuk tak jadi. DAP angkat. Saya pun lepas. Tak apa, Pembangkang jadi elok, elok lah. Pembangkang bikin elok support sama dia. Barisan bikin elok support sama dia. Jangan nak lawan Barisan punya orang tak boleh lepas. Keriau pembangkang punya tempat.

24 Translated from: Itu hari dia orang tanya, professor sekarang sudah satu tahun duduk, lain election mari, profesor sudah pergi lain tempat, sini punya tempat apa macam. ... Prof duduk Pulau Pinang tak apa kita orang boleh pergi tanya you. Prof sudah pi sana KL Johor ke, dia pergi sana, kita orang mau tanya siapa? Dia sudah keriau. "Itu macam lu tak boleh cakap". Dia sudah tinggal itu macam.
} 
[the state government] want to take over the estate, they [the state government] want to take over here and there. Where will they [the state government] place us, we don't know. But Ramasamy said so. Because he [Ramasamy] promised that's why we let go of the temple, demolished. He [Ramasamy] promised, if we do not believe him, we will not let go of the temple. He [Ramasamy] promised to give us a temple and told us not to worry."25 From Muthu's initial description, he had appeared to be conforming to the state government's request of relocating the temple. Nevertheless, it is important to note the hint of anxiety from his narrative, from the way he kept reminding me of the fact that time was running out and that the community still had not heard any news from the state government. Furthermore, he also emphasised the fact that the management committee had agreed to the relocation precisely because of the promises made by the state government. At the same time, his statement has also implied a sense of doubt, since a year had already passed and the community still had heard no news on where they will be relocated together with the temple and school.

Although it is not known if the rest of the community has agreed with Muthu, they neither protested nor confronted the state government following the event of demolition. Instead, they have chosen to abandon the temporary temple. One of the community members described the place as "macam pondok lembu kandang itu macam" (Translated as: "just like a cattle barn"). Bala's wife added, "Nobody wants to go to that temple. During prayer time, many of them refused to go. Only [a] a small number of people attended the prayers." 26 Ranjini admitted that she and her family have stopped going to the temple since the relocation. "We hardly go to the new place, because it is far. When it was here, it was near ... many people would go for prayers; even the children would go and pray, and they would

\footnotetext{
25 Translated from: Ramasamy cakap, PDC mau angkat. Kebun sama estate semua mau angkat ... Satu tahun setengah tak ada, dua tahun saya mesti kasi buat rumah, kubur, tokong, dewan, sekolah semua satu bilik saya boleh kasi. Tapi sekarang sudah satu tahun setengah belum lagi. Jadi estate sini you mau angkat, sana you mau angkat. Mana mau kasi ni, tak tau lah orang mau kasi. Tapi Ramasamy cakap macam tu juga. Ramasamy pasai, sudah janji punya pasai, sudah lepas itu tokong, pecah. Dia sudah janji, tak percaya, itu tokong takkan lepas. Dia janji itu tokong boleh buat, dia kasi sama kita orang tak payah takut.

${ }^{26}$ Translated from: Itu tokong punya tempat pun tak mau mari. Sembahyang pun sini punya orang tak ada mari. Banyak orang tak mau pi. Ada pun sikit orang lah.
} 
stay until after $10 \mathrm{pm}$. Now that it is over there, it is difficult for children. It is not safe." ${ }^{27}$ In fact, the temporary location is only about 300 metres away from the residential quarters and a distance of about 200 metres from the previous location. Bala recalled that on the day when they had to transfer the statues of the deities from the old temple to the new temporary place, no one from the community had wanted to help. "I went to carry the statues of the deities to the new place. No one wanted to go. Only Maaran and I were there." ${ }^{28}$ Jayabalan also spoke of his refusal on visiting the new temple. "I have not gone to the temple because my heart is burning with anger. They [the management committee and the state government] broke the temple and put it there." 29 In one of my fieldwork trips, I have observed that the temporary temple was often left deserted and only loosely fastened with an iron chain.

The deserted temple is not only a demonstration of the community's displeasure. They were also denying the temporary temple as a replacement for their community temple as arranged by the state government and the management committee. It is an act of denying the definition of the situation as seen from dominant groups (Scott 2008, 240). Hence, the desertion is also the community's assertion of their objections to the demolition and relocation of their community temple. Their abandonment also appeared to have had a longer lasting momentum as compared to ad hoc open protests. Even with the temporary temple left deserted, the community was still able to maintain their apparent submissiveness by holding on to the state government's promise in delivering the agreed permanent location for their community temple. The deserted temple has also invited the question of the effectiveness of the management committee's social positions. Pavalan boldly claimed that "If this is not done, I will be the first person, I will face the state government and do a strike here, simple. Whatever truck that is coming here, the dumping

\footnotetext{
27 Translated from: Tempat baru kurang (pergi) sebab jauh, sini dekat lah. Sana budak kecik semua, kuranglah pergi. Sebab kalau malam kah. Kat sini dekat, pukul 10, budak kecik semua boleh balik. Kalau sana susah sikitlah. Sini semua selalu ada orang pergi sembahyang. Budak kecik, sembahyang punya time, semua budak-budak sembahyang baru balik. Sekarang pergi sana susah kak. Kurang pergi sebab tak ada safe lah. ${ }^{28}$ Translated from: Saya juga pergi sana angkat semua mari taruh. Orang tak mau pi, lain orang. Saya dan Maaran pi.

${ }^{29}$ Translated from: I tak pi lagi, sebab hati saya banyak 'juak' punya pasai. Saya hati banyak hangat punya pasal saya tak ada pi. Sebab itu tokong dia orang pecah, that time dia orang cabut ah, dia orang sudah pi taruh sana.
} 
that comes here, I will stop them. I will ask my people to come on the road. We know how to play politics also. Because this is important for the people, we are citizens of Malaysia, and what we have is this estate." It was uncertain whom he was referring to when he said, "my people", as it would unlikely be the community that would be answering his call.

The acts of abandoning the temple by the community and the compliance of the management committee had revealed their political intentions. It is noteworthy that the participants have not mentioned that their collective desertion of the temple is planned. This further suggests that there is an existing embedded and shared sense of scepticism regarding the state government within the community. Due to their experience of the demolition and relocation of the temple, their common class position and social links have brought their subtle act into focus (Scott 1990, 8). The Hindu community's rhetoric of being discriminated against and the advice of staying away from political affairs have indicated that the estate Indian Hindus were reinforcing the prevalent perception of Malaysian Indian Hindus as being a marginalised, discriminated and a powerless minority. By reinforcing this perception of being a discriminated and a powerless group, the estate Hindu community had indirectly put the pressure on the DAP-led state government in fulfilling the promise of a new location for the rebuilding of their community temple. The indirect way of pressuring the DAP-led state government has indicated how the estate Indian Hindus are aware of the party's principle of 'Malaysia for Malaysians'. In fact, they have been manipulating the principle in safeguarding their community temple from permanent destruction. Nonetheless, their actions still entailed the sacrifice of their existing temple structure. In the next section, I examine how they make sense of the demolition of their existing temple structure.

\subsection{The endangered significance of the temple}

Following the state government's demolition on the temple, the management committee had relocated the statues of the deities to a temporary structure. I argue that their willingness for the temple to be demolished by the state government is due to a shift in the meaning of the Hindu temple as a sacred place. My analysis is based on the narratives of the community and the management committee about the temple, before and after the 
demolition. I examine how their narratives about the sakti of the main deity - the Goddess Kaliamman, has demonstrated the temple's importance for the Goddess. Furthermore, I analyse how their narratives had reflected their sense of threats and feelings of discontentment. I also examine the state of the temple after the desertion and its effects on the social positions of the management committee.

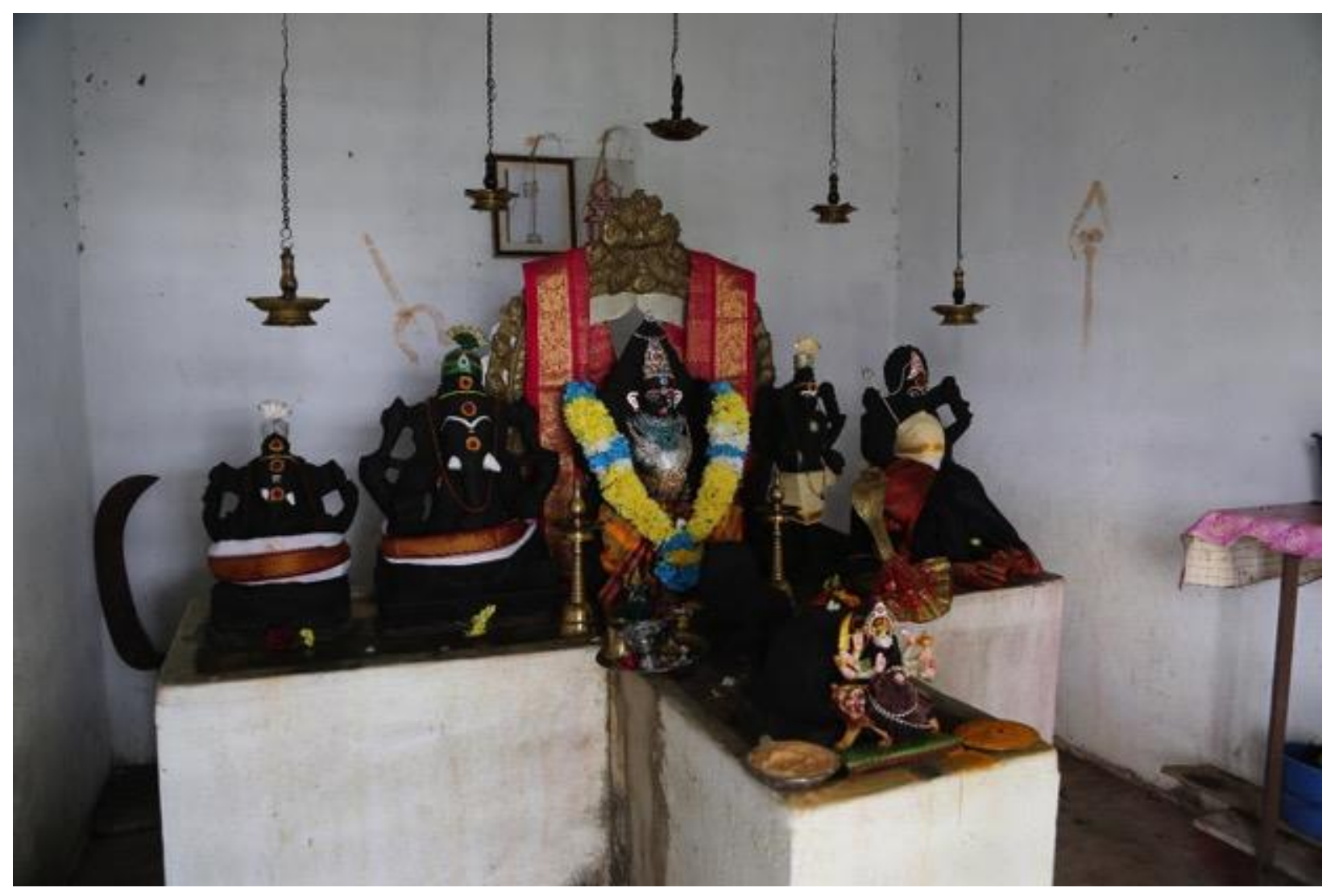

FigURE 5 STATUES OF THE DEITIES IN THE TEMPORARY TEMPLE (PHOTO FROM FIELDWORK)

Since the management committee had willingly allowed for the temple to be demolished and with the abandonment of the temporary temple, I asked Ranjini if they had considered visiting other nearby Hindu temples. From my previous mapping survey in 2012, I found nineteen Hindu temples in Nibong Tebal; four being temples that housed the Mariamman and Kaliamman deities. This Kaliamman temple was one of the three Agamic temples that 
are located within the same town. 30 "We, the estate people, [want] one temple, one school all at one place. This is what we want,"31 said Ranjini. Her insistence on having the temple and the school as part of the community's settlement has reflected the importance of the relocation not only involving the temple and the community but the entire estate settlement as well. It had also implied that the temple and the school have been interwoven with the lives of the estate community and cannot be easily replaced. Ranjini has also indicated that if the relocation had to involve the whole estate settlement, the shifting of the temple as a sacred place would be imminent. The emphasis on having the temple and the school relocated together with the community also indicated how these buildings had not only been important places of worship and education, but they also signify an emblem for the estate community.

Nonetheless, Ranjini is one of the members of the community who had refused to visit the temporary temple. Her refusal on visiting the temporary temple had not been due to her believing that the deities in the temple have lost their sakti, but rather, it was because of her refusal in acknowledging the temporary temple as having the same significance as the demolished community temple. Her narratives are similar to the other participants' narratives on the sakti of the deity. "What is special about the Goddess is that she has power, if we are sick or have requests, they can come true." 32 Their narratives that separate the importance of a Hindu temple and the sakti of the deity are deemed necessary for this case study. The separation of their religious beliefs on the deities and the communal significance of a Hindu temple have suggested two important new perspectives in understanding the function of a Hindu temple for the diasporic Hindus. Above all, this separation has helped them to make sense of the demolition and the shifting of the temple, which is related to whether they agree or object to the relocation's proposal.

\footnotetext{
30 The other two temples were Sri Mahamariamman temple at Valdor estate, which is situated next to this estate; and a temple housing Vinayagar deity, situated centrally in the same town. These two temples were larger in size compared to the Kaliamman temple of this estate. Their structures not only constituted the main temples, but they also each had a hall, usually used for religious classes and special ceremonies, such as weddings.

31 Translated from: Kita orang tanya estate punya orang, itu tokong, sekolah semua satu tempat mau. 32 Translate from: Kalau special tu, dia macam ada kuasa lah, kalau sakit ke, ada hajat ke, kabur lah, jadi lah kalau sembahyang itu.
} 
For those who have objected to the relocation, their narratives often mirrored their sense of discontentment. Jayabalan, for instance, had firmly objected to the relocation. According to him, "They should call the villagers out and prepare a feast. Then prepare proper ceremonies and inform the deity that we ought to relocate her, ask her help to look for a good place to relocate her before demolishing the temple. After she has agreed to the relocation, then we will relocate her. That is the proper procedure."33 Jayabalan's claim is similar to the way he alleged the management committee in disregarding the protests from the community members. Since the management committee also did not obtain the deities' consent, they had failed in their role as patrons of the Goddess. More importantly, by relocating the Goddess without obtaining her permission, the management committee has been disrespectful to the Goddess. Bala agrees with him, as he claimed that none of the members of the community had shown up when they relocated the statue of the deity to the temporary structure. He further claimed that there had not been a proper ritual conducted for the relocation. Instead, he said, "Before the construction of the temporary place is even completed, they already wanted to move the deities there." 34 Jayabalan's and Bala's narratives had reflected their earlier expression of discontentment in the way the management committee had disregarded them. They also indicated that the disregard shown by the management committee had implied their negligence as not only the patrons of the Goddess but also as leaders in the community.

It is also noteworthy that the dismissing of the management committee as the leaders of their community do not mean that the community is disregarding the sakti of the deity. For Jayabalan, the Goddess Kaliamman is not only the guardian for the peaceful lives of the community in the estate; she is also the chieftain of the estate community. "There is only one way. We are living in this world where we believe in the God. Whether we are rich or poor, the Goddess will decide. Before we leave this world, she will handle our lives. She has

\footnotetext{
33 Translated from: ... panggil kampung punya orang, buat makan kenduri, sembahyang elok, tokong sembahyang. Tanya sama dia, tuan tokong itu macam, ini macam dia orang sudah cakap mau pindah kita pun tolong cari you kasi mau mana baru kita tukar, bukan saja mau tolak. Kita tempat mau letak mana kita tolak, lepas itu kita tengok tempat mana, lepas tu DIA setuju, minta tokong semua tu, perlahan-perlahan kasi perlahan-perlahan turun, kita pun mata air keluar, sebab sembahyang lama liao ah, kita mata air keluar, kasi baik-baik taruh ini punya dalam, itu dia punya procedure.

34 Translated from: Sebelum dia punya tapak2 belum lagi siap, dia juga taruh.
} 
the power over the whole of this community. Just like Lim Guan Eng is holding power to govern Penang, she has the power to govern our houses and estate. If someone tried to take the estate, destroy our houses or put a curse on us, she would know. She will protect us. Even if we were involved in an accident, the vehicles could be destroyed by accident, but we would be safe because she is protecting us." 35 Jayabalan's narrative has reflected his devotion to the sakti of the deity, which contradicts with the way he described the temporary temple. However, this is by no means to say that the Goddess and the temple are not connected to each other. The powerful sakti of the Goddess, which is interwoven with the daily lives of the community, requires the temple in order to be effective. "When the temple was at the corner, she protected all the people. During the mornings, before we go to work, and after work, we would pass by the temple, and she would cover [protect] us. Whatever that ought to come, she would cover. Now the temple is no longer there. They took everything and put it there. They just transferred everything there, how could they simply transfer the temple like that?"36 Again, Jayabalan has indicated that the management committee is careless, thus jeopardising the lives of the estate community. Since he has described the sakti of the Goddess as protecting the well-being of the whole community, his allegation implies that the management committee is endangering the lives of the whole community with the relocation of the Goddess.

Nevertheless, this does not mean that Jayabalan believed that the sakti of the deity has been affected after the relocation of the temple relocated from what he believed to be a strategic location for the deity in protecting the community, but rather, her anger had disrupted her sakti because of her objection to being relocated. "This temple should not be taken lightly.

\footnotetext{
35 Translated from: Tokong itu satu cara saja. Kita hidup dalam dunia, kita percaya sama the God. Walaupun kita kaya kah miskin kan sakit kah apa kah. DIA yang handle, Sebelum kita keluar dunia, dia yang handle, Lepas itu apa yang terjadi dengan kampung kita semua dia pegang kuasa, memegang kuasa faham tak, macam Lim Guan Eng memegang kuasa Pulau Pinang semua. Ladang Byram she pegang the kuasa. Power, she got the power already, nobody ... somebody can burn the house. Somebody put the farm. Somebody mau buat kasi jahanam punya kampung she knows already, all she knows already. Penyakit mau masuk dia cover. Ada orang mau buat bomoh sama lu. Dia sudah cover, dia tunjuk sama lu mata. Lepas tu dia jatuh, kereta semua hancur pi, lu masih hidup dia cover.

36 Translated from: The tokong at the corner there. She cover all the people. Pagi pi kerja, balik kerja, all the temple will cover already the corner. She cover, apa yang mau mai dia semua sudah cover. Sekarang tokong pun tak ada, sana pun dia pergi ambik pi, semua just take take take put there. Semua itu macam sudah taruh. Habis tu itu tokong itu macam mana boleh taruh itu macam?
} 
She is not like any other deities. You crossed her once; it's okay. You crossed her twice; its okay, but the third, fourth, fifth and even sixth time, she would not be so forgiving anymore." 37 He further warned that the Goddess had full knowledge of all the misdeeds that took place behind the agreement made between the management committee and the state government for the demolition of the temple. "Many things are happening now. They demolished the temple and took the money. However, she doesn't seem to be taking any action against them. We are also quite curious, why she stays idle. But this temple is very powerful because it is the temple of this estate. We all prayed at this temple." 38 Jayabalan's narrative has suggested that the deity agrees with the community but not with the management committee. His warning had also reflected his feeling of being betrayed by the corrupted management committee. In particular, he seemed to suggest that part of what the community has been submissively waiting for was the disasters to be befallen those who are responsible for the demolition.

The management committee also believed that the relocation had agitated the Goddess. Magesan, a member of the management committee, chose to highlight the punitive nature of her power. He said, "The temple would bring good thing[s] if you pray to her properly. You know why? Because she can cut off your tongue. It is true. If you lie to her, she will cut off your tongue." 39 Magesan continued, "Ramasamy said two years. In two years, the state government will build houses, temple, and [a] school for us. That's what he told us. But now, we don't know where he is, if he wins the next general election, then we are probably fine. But what if he loses?" 40 It is apparent that Magesan's narrative about the sakti of the

\footnotetext{
37 Translated from: Ini tokong tak boleh main punya, Itu Muniandy semua tak apa. Lain semua tak apa, Amma punya semua tak apa. Ular punya semua tak apa. Ini jangan main, Dia sekali bomoh bikin tak apa, dua kali bikin tak apa, tiga, empat, lima kali bikin tak apa, enam kali bikin tak boleh main sama dia, dia mesti lidah sudah keluar, enam tangan hati hangat sudah mari ah, dia punya cara macam tu.

${ }^{38}$ Translated from: Ada macam-macam sudah jadi, itu tokong dia tolak duit ambik. Sudah banyak kali dia orang korek duit ambik, tapi Dia tak ada buat apa-apa. Tapi dia pun tak mau kacau. Tapi ada yang buat itu macam ah. Apasai kita pun hairan lah, kenapa macam itu. Tapi tokong memang powerful lah, Byram punya tokong. Kita orang sembahyang punya.

39 Translated from: Tokong itu sembahyang banyak bagus punya. Apasai itu (lidah) potong punya, itu tokong. Ini potong punya, Ini tokong sembahyang tau ka, banyak betui punya, lu apa tipu tau kah lu boleh mati punya, Itu potong punya. Itu macam punya potong. Kita punya potong. Sekarang pecah punya tau kah, Ini potong punya. Banyak bagus punya tokong itu.

${ }^{40}$ Translated from: Ramasamy cakap. Dua tahun kita bikin rumah kat mana-man. Tokong pun bikin kasi, sekolah pun bikin kasi. Semua dia orang cakap. Jadi sekarang dia duduk mana pun tak tau lah sekarang. Lain tahun Ramasamy menang undi nanti okay, kalau lain orang menang undi apa pun tak ada.
} 
Goddess has the implicit intention of pointing out that Ramasamy as the one who had initiated the demolition and relocation of the community temple. His narratives on the sakti of the Goddess Kaliamman further implied that the Goddess would punish the state government and Ramasamy if they did not keep to their promises of moving the temple to a new and permanent location. His narratives also suggested that the management committee is powerless and therefore, had to agree to the state government's request in relocating the temple. Even though he acknowledged that the Goddess had not been happy with the relocation, the blame is directed to Ramasamy and the state government. With this, Magesan had implied that the shift of blame would enable the management committee to dodge the community's allegation of betrayal.

The different narratives have projected the friction that exists between the management committee and the community and a discursive means of exclusion, a designation to distinguish the 'us' and 'them' (Kinnard 2014, 52). For Magesan, the punitive power of the state government indicates that the 'us' is the management committee and members of the community, while his definition of 'them' implies the state government. Jayabalan, on the other hand, had implied that the 'us' are members of the community including himself and some factions of the state government, while 'them' is referred to the management committee and other factions of the state government. The different narratives gave by Magesan and Jayabalan on the term 'sacred' reflected the flexible nature in the concept of sacred place, which, as Kinnard (2014) argues, is employed decidedly by the narrators. The fluidity in the concept of a sacred place for both Magesan and Jayabalan had revolved around the political rivalry between different political supporters. It is also worth recalling that Ranjini had insisted on having the community relocated together with the school and the temple. From her point of view, the sacredness of the temple is interwoven with the lives of the estate community and therefore, is regarded as part of the estate settlement.

The intense tensions that occurred between the management committee and the community members had resulted in neglect of the temple. I had to visit the temple several times to meet the priest. The priest said that he had volunteered to manage the temple as the previous one had resigned a few days ago. "I will come here if I get off work early. The 
priest is no longer here, so no one here would open the temple. The temple would remain dark. As humans, we need to clean ourselves every day. Same with the Goddess. She also needs to be cleaned every day. Then we can live a better life. If we do nothing, later our lives would be in trouble. Because we already know there is a Goddess here. If we do not have light in our home, how are we going to continue staying there? Same here. If her house remains dark, she will not be happy. We clean ourselves two, three and even four times a day, if not our bodies would smell bad. We also have to clean her at least once a day." ${ }^{41}$ Although he had volunteered to be the priest and the caretaker of the temple, he had also made it clear that he is not a qualified priest. "They [the previous priests] know everything about worship because they have taken the course for becoming a priest. They did ask me to attend the course with them, but I had to work. The course takes about three hours every day; my employer did not approve." 42 In fulfilling his new responsibility, the new priest has begun memorising all the mantras and learning the rituals by helping former priests regularly during ceremonies.

To leave the temple under the care of a less-than-qualified priest also reflected the consequence of an abandoned temple. Without a community's participation, it would be a challenge for the management committee to maintain the temple. It was precisely because of this that they had abandoned the temporary temple, in which the management committee had lost the service of a former qualified priest. Conventionally, devotees who come to a Hindu temple for daily rituals would pay a small stipend of usually one to five ringgit to the priest for performing the rituals. The stipend constituted part of the priest's salary for performing the ritual in opening the temple for the welcoming of worshippers during mornings and evenings. At the same time, since it is a house for the deities, the priest also keeps the temple clean and tidy. Given that the members of the community had

\footnotetext{
${ }^{41}$ Translated from: Bila kerja habis awal. Aku saja mai. Tapi itu sami tak ada lagi, tak ada orang tukar, tak ada orang buka, semua jadi gelap juga. Kita pun hari-hari mandi. Pasai ini tokong pun kena hari-hari mandi. Kita pun hidup senang. Kalau ini kita tak buat apa2, nanti kita semua susah juga lah ... Pasai sini kita sudah tau ada tuhan. Kalau kita punya rumah tak ada lampu, macam mana kita orang boleh duduk? Macam ini juga, macam sini pun, sudah ada satu tuhan. Kita percaya sama dia, kalau kita kasi dia sini semua gelap. Tak ada syok. Kita satu hari, dua, tiga, empat kali mandi, kalau tak ada mandi busuk, macam tu juga lah, kita ikut tu lah, kita mau satu hari satu kali kasi dia mandi juga.

42 Translated from: Dia orang semua tau, sebab dia orang semua pergi course. Pasai dia orang suruh I pi juga, tapi kita orang kena kerja, kita tak boleh ambik cuti panjang. Lagi tiga jam dia tak mau bagi.
} 
stopped going to the temple, the daily income for the priest had also dwindled significantly. According to the volunteer priest, "Nowadays, not many people come here anymore. Last time when the temple was over there, many people would come, especially on Tuesday and Friday. They would visit even on other days as well, at least four people. Now, only two to three people would come on Friday." 43 The decrease in the daily supplementary income had resulted in the two former priests leaving their respective positions. Without a priest, the temple would be left unattended and would not be opened for the worshippers. Therefore, this volunteer priest had decided to oversee the management of the temple although he knew that the members of the estate community had refused to visit the temple. "After the temple has moved here, the community said it is too far. But their houses are just nearby; they refuse to come." 44

According to the priest, the desertion by the estate Hindu community has resulted in an unused temporary temple that is susceptible to deterioration. He said, "This temple used to be very big over there. Now that it is here, it has nothing. During the raining season, here would be flooded. Even now, after I have cleaned this place, if it rains tonight, I would be worried." 45 Its dilapidated state also signified that the temporary temple has failed in its function as a community place of worship for the estate Indian Hindus. Moreover, the abandonment of the community has also indicated that the temple can no longer be the sustaining source of the management committee's social position. As a result, even the members of the management committee seldom visited the temple. "They do come, but seldom. Maybe once a week," ${ }^{46}$ said the priest. As seen from above, the implications of a community's abandonment are severe, which suggests the importance of a community's participation in maintaining the significance of the temple.

\footnotetext{
${ }^{43}$ Translated from: Sekarang tak ramai orang datang dah. Dulu kuil ada kat sana punya jam, orang ramai. Tapi sudah mai sini, sekarang mereka tak mai. Kalau mai pun hari Jumaat saja, Jumaat pun 2-3 orang saja mai. Macam. Bukan macam dulu lah, dulu ramai ada mai. Kalau selau pun, selasa, jumaat ramai sikit. Lain hari semua mai juga, itu kira 4-5 orang mai saja.

${ }^{44}$ Translated from: Sekarang pindah mai sini dia orang ah, kata lagi jauh lah, itu rumah dekat saja, tak ada mai juga.

45 Translated from: Sana lagi besar, sini apa pun tak ada, kalau hujan ini semua air. Ini kali kami cuci kasi semua bersih ah, malam hujan kita pun takut.

${ }^{46}$ Translated from: Dia orang mai juga lah, tapi jarang lah. Mungkin seminggu sekali.
} 
The desertion of the temporary temple by the estate Indian Hindus had already threatened the sacredness of the temple even before the commencement of the demolition and relocation processes. The priest had believed this interdependent relationship to be true that was based from his own experience. "I've heard it. The sound of her anklet as she walked. She was the Goddess. As we walked, she would follow ... I have heard it two to three times now. It usually happened at midnight, twelve o'clock. Not only me, but I was also with two of my friends, we all heard her. After midnight, after we conducted the special ceremony, my friends and I stayed behind to clean up the temple. We heard her loudly; we were quite frightened by it. That was two years ago when the temple was still over there." ${ }^{47}$ Kinnard $(2014,188)$ argues that commitment and involvement of a community are necessary in maintaining the sacredness of a place. Mines (2005) found similar narratives among people in a village in Southern India. The villagers believed that the Goddess tended to wander and when she wandered, she marked the earth with her sakti. Subsequently, the sakti of the Goddess shapes the topography of the village by creating the zones of greater and lesser sakti (Mines 2005, 130). The priest's narratives also seemed to imply a similar function. The wandering of the Goddess around the residence of the estate community denotes her protection on them, while simultaneously providing a communal identification for the community.

With the temporary temple deserted by the estate Hindu community, the priest has discovered that the sacredness of the temple has been compromised. The priest said, "Here have nothing, when the temple was over there, we would hear her." 48 The lack of participation from the worshippers had changed the priest's narrative on the sakti of the Goddess that is residing in the temporary temple. The temporary temple not only failed to function as a temporary replacement of a communal centre for the community, but the priest has also believed that the sakti of the deity has been thwarted because the community's refusal on visiting the temple. The consequence of the desertion by the Indian

\footnotetext{
47 Translated from: ... aku betul betul dengar, Dia punya pun rantai itu bunyikan, Itu dia jalan la, Dia tokong tau. Bila kita jalan ah, dia ikut, Dia punya ikut ... Sudah 2-3 kali saya dengar macam tu, pukul 12 malam. Saya sendiri dengar. Bukan saya seorang saja, saya tiga orang. Malam 12, kita itu jam lepas sembahyang besar, dia orang balik kita tunggu lah kasi bersih, saya dengan 2 orang kawan. Kita pun tunggu dan dia punya bunyi kuat sangat lo. Kita pun sudah takut. Dua tahun lalu. Dulu tokong ada sana.

${ }^{48}$ Translated from: Sini apa-apa pun tak ada. Sana kita ada dengar.
} 
Hindus on the sacredness of the temple has demonstrated how the participation of devotees and the temple as a sacred place are mutually dependent. As indicated in the response given by the priest, the commitment and involvement of the devotees have shaped the narratives concerning the sacredness of the temple. The desertion from the estate Indian Hindu community that resulted in an empty and a deteriorated condition of the temple had affected the way the priest believed about the temple being a sacred place for the Goddess.

The accounts given by the management committee, the community and the priest have demonstrated how the sacredness of the temple as not only determined by the temple per se, but also by the disembodied sakti of the Goddess Kaliamman residing in the temple. The sacredness of the temple is also reliant on the Goddess that is being housed in the temple. The two separate entities yet with an interdependent relationship of the Goddess and the temple is a way for the management committee and the community in making sense of the relocation of the temple. On the surface, their narratives on the sakti of the Goddess appeared to be similar. However, my analysis has shown that their narratives often projected a certain party or individual that they perceived to be the perpetrator of their community temple's demolition. The participants from the community, the management committee as well as the priest, had different opinions about who should be blamed for the disrupted sakti of the Goddess and for the failure of the temporary temple to function as a sacred place. Based on their narratives, it is also evident that the sacredness of a place is subjected to the interpretation and experiences of the devotees, which are linked to their political and social surroundings.

\subsection{Conclusion}

This case study has shown that both the management committee and the estate Indian Hindus had different experiences of engaging with the political situation in Penang. Their different experiences have been reflected in the way they responded to the demolition and relocation of their community temple. On the one hand, the management committee had chosen conformity and compliance to the DAP-led state government, while on the other, the estate Indian Hindu community had chosen to desert the temporary temple and 
possibly even to protest against the DAP-led state government for demolishing their community temple. Their different responses are pragmatic and were centred on their social positions in the community. On the other hand, the general perception of the Malaysian Indian Hindus as a marginalised minority that often portrays their submissiveness as being powerless has also been an important context for their responses. I have argued that the conformity and compliance of the management committee are tactical. Their conforming and compliant attitudes are for ensuring that the state government was being held accountable for the promise of a new land for rebuilding the temple. I have also argued that the responses from the estate Hindu community are indirect acts of demonstrating their sense of discontentment with the management committee.

Both the management committee and the estate Hindu community have demonstrated how they can manipulate the political context in Penang as a way of ensuring that the state government is being held accountable for the agreement made in the demolition and relocation of their community temple. For instance, at first glance, the compliance of the management committee had indicated how they have confidence that the DAP-led state government would uphold the agreement made between the affected parties. I have also demonstrated their confidence to have resulted from believing that they had political backup in the form of BN politicians, who have been on a constant lookout and waiting for an opportunity to challenge the DAP government in Penang. The conformity of the management committee to the DAP-led state government, which implied their submissiveness, had open up opportunities for the BN politicians to challenge the DAP in the event the latter did not live up to what have been promised. The episode on the news of a possible demolition of the estate Tamil school is an interesting example.

On the other hand, the estate Indian Hindu community had threatened that they would not be voting for the DAP in the next general election. They have also indicated that the previous Gerakan-led state government had been more empathetic to the situation of their community temple. The threats of not voting for the DAP had reflected their awareness on how the DAP had won over Penang through the substantial electoral support from the 
Chinese as well as the Indian voters in the 2008 general election. Furthermore, Bala and his wife have demonstrated how they were using similar rhetoric of discrimination and marginalisation of Malaysian Indian Hindus in criticising the DAP-led state government instead of the Malay Muslim-led government. This rhetoric of discrimination and marginalisation implies that the couple are aware of the political rivalry that existed between the DAP and BN, and that they were ready to use the political opposition in safeguarding their community temple from permanent destruction.

On the surface, these power relations often appear to be hegemonic and hierarchical, with the state government being at the top, followed by the management committee and the community at the lowest level. Beneath the surface, those in higher positions had been constantly challenged and were under the scrutiny of those from lower positions. For instance, the management committee had sought interventions from the BN politicians in ensuring the DAP-led state government's accountability on the agreement made with regards to the relocation. On another level, many of the discontented estate Hindu community members had deserted the temporary temple while waiting for the state government to fulfil the agreement.

The desertion of the temporary temple by the estate Indian Hindu community had demonstrated their important role in this case. Their roles are important for the management committee's compliance acts to be effective in safeguarding the temple. As discussed in this chapter, the opinions of the estate Indian Hindu community had not been recognised by the management committee during the initial process of demolition when the objection of the estate Hindus went unheeded. In response, the community's desertion of the temporary temple had implied their refusal in acknowledging the temple, which equates to them denying the social positions of the management committee. This nonconfrontational and indirect approach had effectively diminished the significance of the temple as the source of social power. With the dwindling numbers of devotees, the temple had also lost a qualified priest in performing the daily rituals. The temple has been left to the care of a volunteer unqualified priest, who had tried his best to attend to the Goddess with the daily rituals that he memorised from his previous experiences of assisting the 
former priests in the temple. Therefore, although the compliance of the management committee had enabled them to obtain agreement from the state government to allocate new location, they had lost significant support from members of the Hindu community.

It is also noteworthy that the abandonment of the temple by the estate Indian Hindu community had suggested a shift of perspective that considers the distinctions between their beliefs on the sakti of the deities and their disregard of the temporary temple. Their narratives have demonstrated that the sacredness of the deity remains important but is separated from the temporary building that is housing her statue. The distinction between the deity and the temple has revealed the way the community and the management committee is making sense of the demolition and relocation of their community temple. Their narratives of the deity had often portrayed her to be a living being. Hence, it is not because the temple cannot be shifted due to it being a sacred place, but rather, because the management committee had not sought the deity's permission in doing so.

Their narratives on the sacredness of the deity often projected their own experiences of discontentment, betrayal, insecurity and uncertainty. While the whole community had refused to visit the temple, some members of the community have believed that the Goddess Kaliamman is angry about relocating her statue to the temporary temple. As the community had expected the sakti of the deity to punish the management committee, the management committee has been waiting for the deity to punish the state government if the temple would not be successfully relocated to a new and permanent location as promised. The priest also believed that the sakti of the deity has been compromised with the temple being left deserted.

In contrast to this case, in which the management committee and the estate Hindu community remained sceptical that the state government would allocate a new location for them to rebuild their community temple, in the next chapter I turn to a case of successful relocation by the DAP-led state government. I analyse how this case study appears to be a success story. Above all, I examine how effective is the conformity and compliance of the management committee of this temple in ensuring the successful relocation. 


\section{The temple for the council workers}

The second case study involves the demolition of a Mariamman temple. I identified this temple from a news report about the demolition and relocation of seven Hindu temples. According to the report, the state government had managed to persuade the management committees of these temples to move their community Hindu temples to make way for the construction of new apartment buildings and this Mariamman temple is one of the affected ones. This case has emerged as a 'success story' in the relocation of a Hindu temple that had been situated on the land that belonged to the DAP-led state government. Three major achievements support the 'success' of this case study. Firstly, the DAP-led government had successfully played the role as mediator in the negotiation process between the management committee and the developer, which resulted in the latter agreeing to allocate a piece of land for the management committee to rebuild the temple. Secondly, the management committee has been satisfied with the new location. They were willing to move the statues of the deities from the temple to a temporary building while waiting for the construction of a new structure to be completed. This early relocation is arranged because the management committee has willingly given in so that the developers could begin the project immediately. Finally, not only had the new site been identified, but the developer had also built a basic Agamic temple structure for the management committee. 


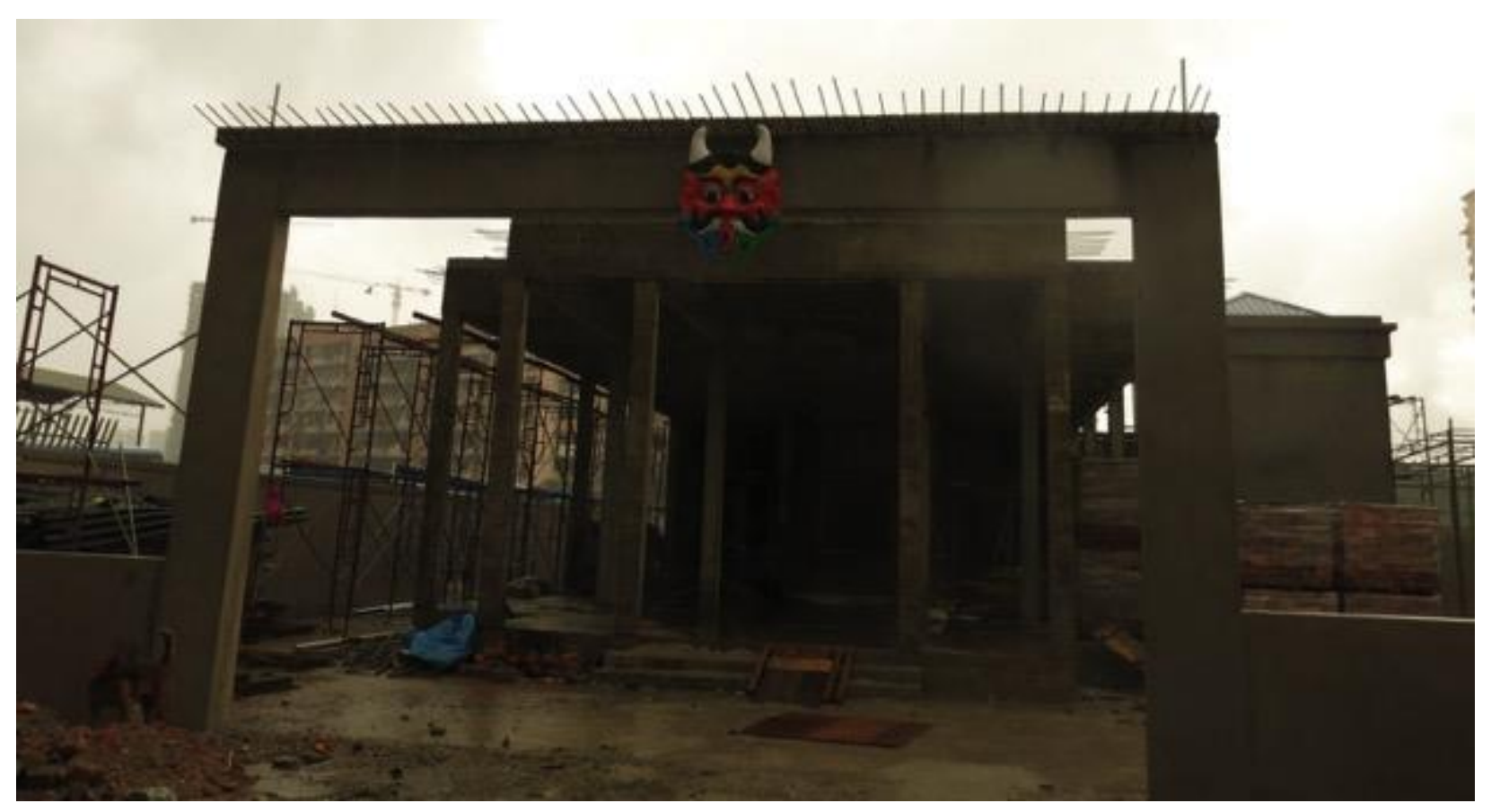

FigURE 8 THE BASIC STRUCTURE BUILT BY THE DEVELOPER (PHOTO FROM FIELDWORK)

In this case, I demonstrate the potential of compliance and conformity as pragmatic and strategic for the Indian Hindu community to obtain a new location for rebuilding their community temple. I suggest that the willingness of the management committee in showing conformity to the state government could be a reason for the government's eagerness in being a mediator during the discussion process between the management committee and the developer. It is apparent that their accomodationist attitudes have provided a convincing performance of their submission to the hegemony of the state gvovernment. Their inclination to comply with the relocation could be another reason that the developer is willing to designate a new location for the temple. Scott $(1990,4)$ argues, it is precisely such open performance of accomodationist and submissiveness that manifests the effects of the hegemony dominant discourses. However, Scott also stressed that such public performance submissiveness may be an intentional act to mislead the outsiders, such as the DAP-led state government, the developer or even me as the researcher. Hence, I examine how the management committee had demonstrated their submissiveness to the DAP-led state government. Moreover, this case is also important to demonstrate the importance for the management committee of obtaining conformity from the members of the community that the temple serves. Subsequently, I also analyse the part played by the members of the 
Indian Hindu community, where I examine the importance of their role in ensuring a smooth demolition and relocation process of this temple.

As well, this case study also suggests the importance of the improved socio-economic conditions of the management committee as a factor in its successful relocation. I suggest that the improved socio-economic conditions of the management committee have also improved their social influences among local Hindu communities. Their increasing social influence has further prompted the state government to help them effectively in negotiating with the developer to allocate a new location to rebuild the temple. I further investigate the effects of the urban location of the temple on the socio-economic conditions of the management committee, and the effects of their improved socio-economic conditions on the political significance of their community temple.

Although this case had seemed to be a 'success story', the relocation also entailed the demolition of the temple, which they had built, expanded and refurbished over the decades. Since the temple is an important religious and communal centre, the question remains as to how the management committee had made sense of the relocation, thus accepting the trade-off that came in the forms of monetary compensation and a new location for the temple. This included how the management committee had shifted the meaning of the temple by using rituals in associating its relocation as religiously significant. The purpose of the relocation ritual is to demonstrate the Goddess' consent of being relocated to a temporary building. The management committee had intended to convince the worshippers that the decision is an outcome of divine intervention from the Goddess. Hence, through ritual performances, the management committee appeared to have shifted the worshippers' focus on the temple's significance as a communal emblem of the community to the sacredness of the temple as an abode for the Goddess. I also demonstrate how the management committee had used rituals in obtaining a symbolic commitment from the state government to not relocate their community temple again in the future.

I begin by examining what had made the relocation of this temple a success story for the DAP-led state government, the management committee and the community. Then, I examine the rhetoric of conformity by the management committee. This analysis is based 
on the way the management committee deliberated over the process of relocation and their narratives about the new location. I investigate their motivation in maintaining the rhetoric of conformity. Then, I observe their conformity thresholds towards the state government and the challenges they faced in rebuilding the temple as a way of further justifying how their conformity is a tactical act. Subsequently, I analyse how they have reinforced the religious and communal significances of the temple in retaining the support and trust of the community. This has included the way they maintained the function of the temple through elaborate rituals, specifically the relocation rituals, which is the Balathanam ceremony.

\subsection{The successful demolition and relocation of this temple}

The appeared 'success' of this case study is precisely due to the satisfaction expressed by the management committee and the community members during the interviews. Their satisfaction was not only because they had found the new location to be suitable in rebuilding their community temple, but also the promptness of government to help them in obtaining the developer's agreement for the provision of the new location. In this section, I argue that the appeared satisfaction of the management committee and the local Hindu community are tactical acts of conformity and compliance to the DAP-led state government. To analyse such tactical acts of conformity and compliance, I begin this section by examining participants' accounts of the historical, political and social significance of the temple. Analysis of this significance of the temple reveals two important points. Firstly, it reveals the temple as a sacred place bears a communal significance for the Hindu council workers. Hence, the demolition and relocation is a sacrifice that the management committee and the Hindu community has to make for losing the existing building of the temple and its location. Secondly, it suggests possibilities for the prompt assistance of the DAP-led state government to help the temple committee to obtain a new location from the developer.

Then, I examine their conformity and compliance with the DAP-led state government for demolishing and relocating the temple as pragmatic and strategic moves. I also examine their expressions of satisfaction in the changes of their community temple as a means of comprehending the way they make sense of the sacrifices made as a result of the 
demolition and relocation of their community temple. Since the demolition and relocation processes of this temple are still under progress, the management committee has to carry on with their show of compliance and conformity to the state government. Nonetheless, I also examine the limits of their conformity and compliance to reveal such acts as pragmatic and tactical.

\subsubsection{The historical, political and social significance of the temple}

In this section, I begin by examining the significance that the temple carries for the management committee and the Indian Hindu community. I contend that the significance of their community's place of worship is diverse and is subject to the way they make sense of the demolition and relocation of their community temple. According to the participants, the significance of the temple is constituted of its century-old history and its function as a communal emblem for the management committee. Furthermore, the significance of this temple had also been due to its location in the city and not in isolated estates and plantations. I suggest that the management committee and the Indian Hindu community members of this temple has undergone socio-economic changes, which the Indian Hindus living in the estates and plantations had been deprived of. Such changes had impacted on in the expansions and refurbishment of the temple over the years before it was demolished. Therefore, I also examine how the changes in the socio-economic conditions of the Indian Hindu community had enhanced the political and social significance of this temple. On the one hand, the enhanced political and social significance of this temple further reveals the degree of sacrifice that the management committee and members of the local Hindu community had to make as part of their pragmatic acts of compliance to the state government. On the other hand, I also contend that it is precisely due to the enhanced political and social significance of the temple which had made the process of demolition and relocation of this temple appear to be particularly successful. Therefore, I also analyse how the enhanced political and social significance had also been influential in the success of this case study.

According to the management committee, this temple had been built more than a century ago when the British were colonising Malaya. Manikam, a seventy-one-year-old devotee, 
has been a member of the management committee since 1981 and had learned about the background of the temple from his father. "Before I was born, this temple was given to us by the British government to the council workers and labourers. At that time this temple was small, about ten by ten feet only." As this temple was established for the Indian labourers, the British could have assumed that the temple would be a temporary edifice, hence, its small and simple structure. Similarly, with the other temples that had been set up for the labourers, the British did not see the need of giving a land entitlement for this temporary place of worship.

It is also noteworthy that the initial purpose for the British government on building this temple had not mainly been to cater for the religious needs of the Indian Hindu labourers. Instead, the British government was trying to ease the tensions that occurred between the lower caste Indian Hindu labourers with those from the upper castes in the city of George Town. Manikam claimed, “There is a Mahamariamman temple at Queen's Street. In the early days, the labourers used to pray at that temple. However, due to the caste system, the management committee refused to let the labourers continue to visit or to pray at the temple." Arasaratnam $(1979,168)$ also observed rigid segregation of castes in Malaya from the 19th century until 1935. Before 1935, the lower caste or the 'untouchable' Hindus in Malaya were forbidden from entering lineage temples. Manikam said, "There was a fight among them [the different Indian Hindu communities]. So, the police arrested the people and brought them to the magistrates' court. The [British] council chairman at that time came to know about the situation. So, he showed the labourers this place and built this temple here for the labourers. The incident happened during the 1930s. My father was one of many people arrested by the police, given the chaos." Manikam also claimed that "there was no temple here [Kampung Jawa Baru] before ... The [British] government gave them [the previous management committee] a yearly [monetary] allocation to pray." The British's annual monetary contribution to this temple had reflected their acknowledgement of the temple's importance, but not necessarily for the labourers. Instead, the British might have perceived the temple to be important for them since the temple has been useful in maintaining the distance between the Indian Hindu labourers and the upper caste Indian Hindus from the city. According to Manikam, “...these people [Indian Hindus] were all 
labourers, working here. And the people there [at the centre of George Town, where the Mahamariamman temple is situated] were all businessmen. So they [the Indian Hindu businessmen] wouldn't like these people [Indian Hindu labourers] here. So that was the problem." Since the temple has been situated in that part of the township, most of the Indian Hindu residents who had been labourers eventually became council workers for the Malaysian government after Independence.

Moreover, based on Manikam's historical account, this temple had evidently gone through several refurbishments and expansions over the years. However, it is important to note that the management committee had never obtained the land entitlement in which the temple had been situated on. The expansion and refurbishment of the temple over the years had reflected the management committee's confidence that their community temple would continue to exist on government land. Bayat $(2013,17)$ conceptualises such acts of expansion without the formal entitlement or ownership as 'quiet encroachment' - "the silent, protracted, but pervasive advancement of the ordinary people on the properties, powerful or the public, to survive and improve their lives" (Bayat 2013, 56). Bayat (1997, 5) argues such encroachment is, indeed, different from the 'everyday resistance' of the subordinate groups becayse it is not essentially defensive. As reflected from Manikam's interview the expansion is part of the nature of the religion. Nonetheless, the expansion of the temple has challenged the state government's prerogatives - "including the meaning of order, control of the public space, the importance of modernity, and finally the state's encroachment on private property" (Bayat 1997, 5). Hence, the expansion and refurbishment of this temple by the management committee had indicated how the members of the Indian Hindu community have been rooted in this area over the years. Therefore, the temple had become a communal emblem for the Indian Hindu labourers and council workers.

Apart from its historical background, the social significance had also been due to the management committee's and the Indian Hindu community's commitment in making the temple as their communal emblem. Manikam said, "We [the management committee] save ... save ... save ... until 1974, we build this temple. Public also donate, to build this 
temple." Manikam also claimed that with the continuing expansion of the temple, its popularity too had increased over the years. "Before, this temple is very quiet. Nobody came here. There were only a few of us. Back then, the priest was also one of my friends. We go door to door to ask people to come to this temple. That was how we started. Today, if you mention Mahamariamman in Penang, everybody will think that you are talking about this temple. Everybody knows about this Mariamman temple." As the Goddess Mariamman is one of the most common village deities worshipped by the Indian Hindus in Malaysia and Penang, Manikam's sense of pride was evident when he claimed that their Mariamman temple is one of the most prominent ones among the many Mariamman temples that are located in Penang.

As a communal emblem, the contribution from the management committee and the Indian Hindu community are an indication of their commitment and acknowledgement of it being their community temple. As a result of their commitment and offerings, the former elaborate structure of this temple not only made a statement regarding its presence in the vicinity but also signified the increasing prominence of the community members of which the temple served. As seen in the picture above, the structure of the temple had a vimana, a mandapa and at least one (raja)gorupa, which could be seen from a distance. Located at the outer part of the Agamic temple was a storeroom where the chariot used in processions during the Navratri festival is kept. Situated next to the temple was a kitchen and the priest's room. Complying with the state government in demolishing this temple structure had meant that the management committee and the Indian Hindu community were willing to sacrifice their existing communal emblem. The demolition would also signify a loss of its historical legacy and the generational memories imbued in the temple's structure. 


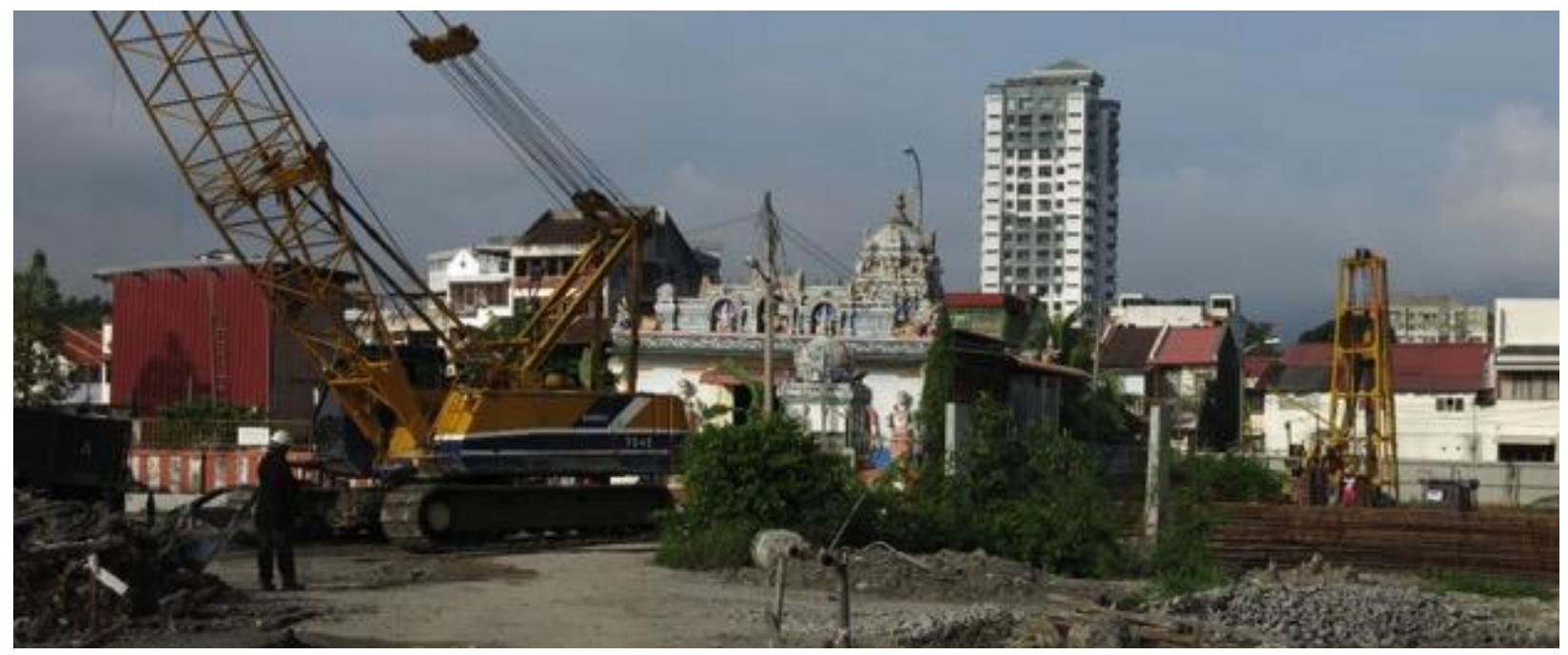

FigURE 7 THE TEMPLE BEFORE THE DEMOLITION (PHOTO FROM FIELDWORK)

Furthermore, as a communal emblem, the expansion and refurbishment of the temple had also suggested an improved socio-economic status among the members of the Indian Hindu community. For example, Manikam has a daughter who is working as a nurse in one of the private hospitals in Penang. Another member of the management committee, Siva, is holding an engineering job in a transnational company factory. I have also met another member who said that his daughter had previously worked for the United Nations and is currently studying for her PhD in the United Kingdom. He has also introduced his son-inlaw whom he claimed is a businessman and had come for a visit from Singapore. It is apparent that the following generations of the management committee had managed to transition from being a working class to middle and even upper classes. Since the temple had previously been a facility to separate the lower and upper caste Indian Hindus, Manikam and many members of the management committee seemed to take pride in their improved socio-economic status.

However, Siva, another member of the management committee, had a different viewpoint about the extended temple structure precisely because of the improved socio-economic status of the management committee and the Indian Hindu community. Despite the expansion of the temple over the years, he stressed that the temple had not been a traditional Agamic temple since it had initially been a place of worship for the labourers. He said, “...this type of temple is normally found in the estates... and they are usually not in 
proper [Hindu] temple structure". Hence, while Manikam's account has reflected the sacrifices that the management committee had to make for complying and conforming to the demolition and relocation of their community temple, Siva opined that the demolition and relocation would give the management committee an opportunity to rebuild their temple "to be totally different from what it had been earlier. It is going to be bigger, more grand, the outlook will be totally different." The opportunity of rebuilding a completely new temple appeared to signify a new beginning for the management committee and the Indian Hindu community, one that will put an end to their past as Indian Hindu labourers. Although Siva's opinions are different from Manikam's, his statement, however, are important in reflecting how the temple carries a significant function of displaying the socioeconomic status of the management committee. A bigger and a grand temple structure would equate to the management committee's higher social standing.

As the Indian Hindu labourers for whom this temple had been built for were residing in the city instead of the rural estates and plantations, they had the opportunity of assimilating themselves with the major political and social developments in Penang. At the same time, this temple had also been part of some of the major events in the city. For instance, Manikam recalled, "After Indian Independence in 1947. The Prime Minister of India, Nehru, came here. Because at that time we called it, small India. All the Indians were here, you know. At that time, the temple was small. He came and raised the Indian flag." Manikam's claim of "all Indians were here" suggested many Indians who lived in the area had made it a "small India". The visit by Nehru, as he claimed, suggested the possibility that the Indian leader had come to this area in of his visits to Malaya (Sandhu 1969, 299). A long-time volunteer helper of the temple, Chandran backed up Manikam's claim. Chandran has also stressed that Nehru had raised the Indian flag on top of the temple. According to Sandhu $(1969,301)$, around the late 1940s, the Indian leaders in India had urged the Indian migrants to decide if they had wanted to remain as citizens of India or become the citizens of the countries where they reside in. Although I could not locate any sources in justifying both claims, their recollections of Nehru's visit have remained significant. This is because the location of the temple in the city had suggested easier accessibility for the Indian leaders to visit the temple as compared to those situated in rural estates and plantations. 
Therefore, the claim of Nehru's visit had implied the Indian leader's acknowledgement of the temple's prominence. The incident on the raising of the Indian flag over the temple building, as claimed by Manikam and Chandra, had further reified the communal significance of this temple for the Indian Hindu labourers and the council workers residing in the area.

Siva has also mentioned, "The people asked the Alliance government to build the temple bigger for them. In 1969, they built a bigger temple for us." Siva has also brought up the refurbishment of the temple, "At that time the CM [Chief Minister] Lim Chong Yew came over for the consecration ceremony." It is noteworthy that the Chief Minister, Lim Chong Yew had resumed his position for a year when he visited the temple. Lim's visit had suggested an acknowledgement of the temple as the communal institution for the Indian Hindus, specifically those from the lower and working class. Nevertheless, I also suggest that Lim's acknowledgement was politically motivated. Sandhu $(1969,301)$ argues that the Indians in Malaysian, although regarded as a minority, had a substantial voting strength in determining the political dominance between the Malay and Chinese leaders. Hence, for Lim to resume successfully the position as the first Chief Minister in Penang had meant that there had been a significant contribution from the Indian voters. Therefore, Lim's visit to the temple could be his attempt at maintaining support, particularly from the lower and working class Indian Hindus. For Siva, on the other hand, Lim's visit has added a political significance to this temple, which further reinforced its prominence especially among the Indian Hindus in Penang.

In summary, this subsection has demonstrated the temple's historical and social significances. The significances for the management committee and the Indian Hindu community would be changed simultaneously due to the demolition. In the next section, I turn to the appeared satisfaction of the management committee to the demolition and relocation of the temple. Their satisfaction with the demolition and relocation invites the question of how they made sense of such drastic changes and threats to their community temple. 


\subsubsection{Conformity and compliance as pragmatic and tactical acts}

The historical and social significance of the temple invites the question of why the management committee still decides to comply with the demolition and relocation of the temple. In this section, I suggest that reasons to comply with the state government could be diverse among the members of the management committee. While some of them might choose to comply with the state government to show conformity others might choose to comply as a pragmatic way to safeguard the temple. More importantly, I demonstrate how the management committee has seen the demolition and relocation as an opportunity to rebuild a new and prestigious Agamic temple. Hence, I analyse their reasons to comply with the state government. I also examine what constitute the satisfaction of the management committee, and how do they make sense of the demolition and relocation of their community temple. Furthermore, I also investigate the acceptance of the members of the local Hindu community of the decision made by the management committee.

In my initial interviews with a few members of the management committee, they gave two main reasons on why they are satisfied with the new location. Firstly, they were happy that the developer had allocated a land that had the same size as their former site. One of the members, Manikam, said, "Everything is okay. This [the new location] is the same size." Secondly, according to Manikam and Siva, the relocation had given the management committee an opportunity to rebuild their temple in a proper Agamic form, with "the dome and all". Siva, another member of the management committee and the project manager that oversees the rebuilding of their community temple, explained, "We are giving a better uplifting [a refurbishment] for the temple. The [new] one [temple] that we are constructing is based on all aspects of our Hinduism and traditional way of constructing it." Since the developer had already built the basic structure of the temple for the management committee, the latter just needed to assemble the religious emblems and decorations for the temple. In a few of my visits, Siva has mentioned that the management committee had hired artisans from India to design and decorate the temple so that it complied with the "Hinduism and traditional way" of an Agamic temple. On one of my visits, I also met with another member of the management committee who briefly commented that the place where I have parked my car would be turned into a proper parking lot for the worshippers. 
The new location that is situated on the main road also would make it more visible to the public and much better accessibility for the worshippers.

Based on the initial responses from Manikam and Siva, the demolition and relocation are more of an opportunity than a threat to them, even though they had given their consent on having their existing temple's structure demolished. This is because the new temple would be upgraded and the management committee has also hinted that the temple would have a more prestigious outlook. They seemed to believe that the relocation would enable them to assert further their religious presence through a proper temple that will be bigger and grander than the previous place of worship. The Agamic temple structure also seemed to indicate that the demolition and relocation have improved the religious sacredness of the temple. According to Gill $(2010,129)$, in a traditional Hindu Indian society, the structure of a Hindu temple also often provides Hindus with a visual symbol of authority. The visibility of the new Agamic temple would effectively reinstate their presence as the Hindu worshippers in Kampung Jawa Baru. Hence, the management committee has transformed the apparent threats of demolition and relocation into an opportunity for reasserting their presence in the area. The shift of perspectives by the management committee toward the demolition and relocation of the temple had enabled them to accept the dramatic changes on their community temple.

However, this acceptance and shift of perspectives did not happen instantly when the management committee received the news about the relocation of their community temple. According to Manikam, "We wanted to stay here. Then, the CM [Chief Minister] told us that there would be a group of Malays coming to stay here. They [the state government] will build a flat here for them. One flat full of Malays. So, the CM said if the temple remains here, there would be a problem for the Malays. So, he suggested that it would be better to relocate our temple." The fact that the new Malay residents would be moving into the area had reminded the management committee of the infamous Kampung Rawa incident that occurred in 1998. As mentioned in Chapter Two, the Kampung Rawa incident happened in March and April 1998 and had involved a series of riots between the Indian Hindus and Muslims. During the riots, a Hindu temple was severely attacked and vandalised. For that 
reason, the former state government had proposed to relocate the affected temple to Kampung Jawa Baru as a way of resolving the tension. The current location of the temple is about five kilometres away from Kampung Rawa. ${ }^{1}$ Manikam's narratives had reflected his cautiousness in his avoidance of any possible clashes, which had made the relocation necessary. The strategic new location is the secondary reason. Therefore, although the members of the management committee might not have initially agreed to the relocation, their subsequent willingness, however, has suggested that it is a pragmatic and a strategic move for them to conform and comply.

Moreover, the case of the Kampung Rawa riots that led to the relocation of the temple could be an example for the management committee to suggest the effectiveness of conformity to the state government. Siva said, "At the end of the day if it [the land] is not yours, it is not yours. If you have to move, means you got to move. That is what happened in this case also." As it appears, Siva has indicated that it is inevitable for the demolition and relocation. As the land does not belong to the temple, it is only pragmatic and necessary to surrender the location back to the government. However, I agree with Scott $(2008,324)$ that such display of necessary pragmatic resignation does not mean that the subordinate equates the inevitable with justice. Siva's implicit agenda for his rhetoric of conformity prevailed as he continued, "And yes definitely, it [the relocation] will go with some compensation. It cannot run away, right." He implied that if it is inevitable for a century-old but illegal temple to be demolished and relocated, it would also be inevitable for the authorities to look for a new site of the temple's relocation. Siva's implication has suggested a tactical and artful manipulation of deference - "the subordinates artfully manipulated the stereotyped view of them, and took advantage of their subordination to achieve their goals" (Scott 1990, 34). This act of manipulation by the subordinates is their subtle and indirect way of challenging the dominant power relations (Scott 1990). Siva has also denoted that the conformity is intended to gain some level of compensation from the state government. Furthermore, their reason for relocation has also indicated the autonomous power of the management committee in the community. Their cautiousness in avoiding any possible tensions with the

\footnotetext{
${ }^{1}$ The new location of the temple was about two kilometres away from the former location of the Sri Raja
} Mahamariamman temple. 
new Malay majority residents at the site has implied that they do not intend to rely on the state government should any conflict arises. Manikam seemed to suggest that their compliance with the state government's proposal to relocate the temple is a necessary and pragmatic measure for protecting the temple.

Even with the compliance of the management committee, they acknowledged that not all of the community members had agreed with their decision. Siva said, “Anybody also won't be so happy if you ask them to move from one place to another because they are so comfortable with the place. Now they have to get out of the place." Nonetheless, he insisted, "I mean yes people can talk a hundred and one things. However, we must look at God as the priority. If we got to move it means we got to move." By mentioning God as the priority, Siva seemed to be reiterating the responsibilities of the management committee as patrons of the Goddess in the temple. Those who disagree with the demolition would be attempting to question the status of the patrons' positions that are granted by the Goddess Mariamman of the temple, which is to say that challenging the patrons' positions would be likened to challenging the authority of the Goddess. This rhetoric of claiming their social positions as the management committee is similar to the management committee of the temple in the estate. In this case, however, it appears that their assertion of power relations is more effective than the attempts of the management committee of the estate temple.

The seniority level of most of the members of the management committee could also be a reason that sustained their effective social positions. The difficulties that they faced in maintaining the temple had reflected their attachment and commitment, hence, earning the younger members' and worshippers' respect. The respect gained from the younger members and members of the community has also enabled the management committee to establish and retain a well-defined hierarchical institution in the management of the temple. According to Siva, "Whatever I do, I do with the blessing of the temple chairman. I want to make sure that he spoke on behalf of the rest of the members when we make the decision, and I do not decide on my own." The management committee had given Siva the responsibility of managing the construction process. "I am getting full support from the temple chairman ... the final decision has to come from him." He appeared to have 
understood that the responsibilities do not involve sole decision-making power, which further demonstrated the effectiveness of the hierarchical institution.

The members of the community also appeared to respect the prevailing hierarchical institution of the temple. The worshippers that I have met often claimed that they were in no position to express their opinions on matters related to the relocation of the temple. They appeared to trust and rely on the decisions made by the management committee. Chandran is one of the worshippers who has been volunteering his services at the temple and worked for the Penang local council. He claimed that he had started visiting the temple since the age of six. Despite his long association with the temple, he has refused to discuss matters concerning its relocation even after he has agreed to the interview. He said, "I am not even a member of this temple. I only come here for the past sixty-four years. I am just a volunteer. I volunteer because the priest is my hometown man, you know, in India. So, I just come and help. I do not think I should comment a lot about this temple. The [management] committee will not be happy." Chandran's reluctance has suggested that he is aware of his position in not disclosing the events that had taken place within the management of a temple to an outsider. This also shows that he is aware of the temple's hierarchical institution. I find that their respect and trust have further cemented the communal boundary surrounding them, which outsiders like me would have a hard time penetrating.

Because of the effective hierarchical institution, the management committee and the community appeared to have shared the effort in maintaining a seemingly peaceful relocation. Unlike the resentment, anger and contradictory claims shown by the estate community from the previous case study, this community had reacted in an almost uniform manner. Ramani, a worshipper who has been visiting the temple since she was young, said, "The state government has been helpful to give us another new place for the temple. If we have to move, we have to move." Chandran, who had reluctantly agreed to be interviewed, had similar rhetoric of satisfaction about the relocation of the temple. "If BN [Barisan Nasional] means surely they will not give [us a new place to rebuild the new temple]. This DAP, Ramasamy did his part." The compliment on Ramasamy is different to the resentment and scepticism directed from the estate community. This has made the management 
committee's and the community's expression of conformity more convincing since they displayed no resentment or any sense of loss as a result of the relocation, which further reinforces it as being a 'success story'.

In the next section, I examine the political bargain for this case study that had made it 'successful'. I ask: How can the expressions of satisfaction, conformity and compliance of the management committee and the Indian Hindu community be identified as pragmatic tactical acts? How did the management committee use the compliance and conformity approach in securing the agreement made with the state government? What is the thresholds of their willingness to compromise with the state government?

\subsubsection{Ongoing negotiation and limits to conformity}

As I have argued in the previous section, the tactical acts of conformity and compliance by the management committee, in this case, had appeared to be more convincing as compared to those from the previous study of the estate Hindu temple. In this section, I turn to the conformity and compliance thresholds as a way of revealing how these had indeed been tactical and pragmatic acts shown by the management committee of this temple. I begin by examining how the management committee still required financial help from the state government in rebuilding their community temple. As the management committee has been cooperative with the state government and the developer, I examine how the management committee had expected the state government to help them. Then, I seek what constitutes the limitations of their conformity and compliance. As they consistently complied and conformed, I also ask: What are the significances of this community temple to the management committee and the Hindu community?

According to the news report about the relocation of this temple, the state government had promised to compensate all the seven temples for the cost of relocation. However, the management committee claimed that they had not received any monetary compensation from the developer or the state government, even though the developer had already allocated the land and built the basic structure of the temple for them. For the management committee, the rebuilding of the temple has been particularly difficult, since they did not have sufficient funds for the reconstruction. Manikam explained, "We refurbished this 
temple about six or seven years ago. For the refurbishment, we had already asked the people [members of the management committee and the worshippers] for donations. So, we cannot ask them for more money now. So, I told the developer, 'We need more [money] compensation.' But, they said, 'We cannot do anything, I will do what I can to help you.' We will wait and see how they can help us." It seems that the management committee has been in an urgent need of funds to rebuild the temple. Siva said, "At the end of the day getting the temple land and the structure is not sufficient, we must complete the temple."2 The anxiety due to the lack of financial means in rebuilding the temple had weighed heavily upon Manikam and Siva. While the developer claimed that they could not help them, the management committee could only hope that the state government would give them some form of financial assistance. Siva said, "I have spoken to Prof. Ramasamy personally. He said he would give [us funds to rebuild the temple], but he never said how much he is going to give. So, we still waiting for the state government's contribution." Since the management committee had asked the Deputy Chief Minister, Ramasamy for financial support in the reconstruction of the temple, it means that the management committee would have to continue showing their compliance to the state government. However, this does not suggest that the management committee would not seek other means for funds. Siva also said, "On 30th of January, we are going to organise a show plus dinner for fundraising. So, I estimated the turnout to be about 1,000 people. So now we are selling tables [tickets for the dinner event]. That is how we are getting our funds for the temple." His proactive approach has suggested that even though he said that the management committee has been willing to wait for the state government to help them, he had also doubted that they would be receiving the funds from the state government anytime soon.

Siva's doubt is mainly because the management committee had rejected a proposal from the state government in registering their community temple under the PHEB. Manikam has revealed that the land of the new location had not belonged to the temple. "The land they [the developer] are going to give to the temple. [sic] I do not know how they are going to

\footnotetext{
${ }^{2}$ It is important to clarify that the management committee had not obtained the ownership of the land. However, this is by no means to allege that Siva's claim is doubtful. Rather, I interpreted his remark to indicate that the developer had allocated the land for them to rebuild their temple. The allocation does not equate to giving away the ownership of the land to the temple committee.
} 
give. However, they said they are going to give." Manikam seemed to believe that the developer has been willing but is restrained from allowing the temple to own the new land. He revealed, "They [the developer] are having some problem with the HEB [Hindu Endowment Board]. As stated earlier, the HEB had invited the management committee to register their community temple under the Board, which had explained the prompt and effective intervention from the DAP-led state government in ensuring a successful relocation of this temple. However, we said we do not want, [sic] later will be a problem. So, let the land belong to us. So that is the problem. We do not know what is going to happen to that [the transferral of the land ownership]." Their refusal has indicated that the state government's proposal had tested the compliance and conformity thresholds of the management committee. It has also suggested Siva's doubt that the state government would be supporting them financially in the rebuilding of their community temple.

Furthermore, as recalled from the previous case study, if a Hindu temple has no land ownership on the land of which it is situated on, the temple would be confronted with an uncertain future. However, as Manikam claimed, "later will be a problem" for the temple, he seemed to believe that the threats against the temple if registered under the HEB would be more severe than if the temple had remained on the government land. Manikam further explained, "Like if we have something that we want to repair, the renovation has to depend on them [the HEB]. They will have orders. So, if they say cannot, we cannot do anything." This severe 'problem' had appeared to be the loss of the committee's autonomous management power. "So if the government want the land to go to HEB, we say, the land you keep. Everything that has to do with the temple belongs to us. We do not want to talk about that. Just cut to that." Manikam could be right for being concerned about the loss of control over the management of the temple. The current HEB still maintains Section Four of the Ordinance of Ninety-Two: Mahomedan and Hindu Endowments 1905, which states that the 
HEB has the authority to take over any endowment that is proven to be mismanaged by the trustees of the endowment. ${ }^{3}$

As mentioned in Chapter Three, the HEB under the leadership of Ramasamy has managed to register three new Hindu temples. ${ }^{4}$ However, Ramasamy has not implied if the Board take over the management of these temples are due to their mismanagement. Instead, he emphasised that the registration of these temples under the Board are necessary as a way of overcoming the difficulties faced by the temple committees in managing their temples. As mentioned in the same chapter, many temple committees are suspicious of the Board taking on the management of the Hindu temples. They perceive the Board as a device for the encroachment of the DAP state government in the matter of temple management. Based on Manikam's reaction, the management committee of this temple seemed to have a similar perception about the PHEB.

The firm refusal has also revealed how the management committee is careful in dealing with the state government and the developer. This further suggested that their conformity is a calculated move with a careful analysis of what they could gain and lose. While they are willing to cope with the destruction of their century-old temple structure, they were careful about not losing the control of the temple's management to the state government. It further suggested that while the concrete building of the temple had remained its importance of being a house of worship, it had also been a source of social influence and position for the management committee. Since the management committee had intended to safeguard this source of their social influence and position, they had to comply with the relocation of the temple.

\footnotetext{
${ }^{3}$ According to Ordinance Ninety-Two: Whenever it appears to the Governor in Council on the report of any such Board in any Settlement that in such Settlement (a) any endowment has been mismanaged; (b) there are no trustees appointed for the management of any endowment; or (c) it would be otherwise to the advantage of any endowment that the same should be administered by the Board in that Settlement, the Governor may order that such endowment shall be administered by the Board in that Settlement (Mahomedan and Hindu Endowments 1920).

${ }^{4} \mathrm{~A}$ Vinayagar temple was registered under the Board because of deregistration of the temple by the Registrar of the Society. A Murugan temple was registered under the Board as a condition of the land transfer by the Penang Development Corporation. Due to financial difficulties, the management committee of a temple in Nibong Tebal voluntarily registered their community temple under the Board. According to Ramasamy, the Registrar of the Society has approached the Board to manage the issue of registrations of twenty-six temples.
} 
While the hierarchical institution of the temple has remained significant, it is simplistic to presume that the management committee could sustain support from the Indian Hindu community with their level of seniority. The interdependence between the political and social significance on the one hand and the sacredness of the temple on the other had also been equally important for the management committee in sustaining support from the Hindu community. Hence, in the next section, I analyse what constitutes the sacredness of the temple. How do the management committee and the Indian Hindu make sense of the relocation of the temple as a sacred place?

\subsection{Spatial claims of the new location}

As the management committee has not obtained the ownership of the land, the possibility remains for future threats to the temple to be demolished and relocated again. In this section, I adopt the framework of sacralisation by Mol (1976) to investigate the concerted efforts of the management committee and the local Hindu community to sacralise the new location. The sacralisation process suggests that the temple can be demolished and relocated. Mol (1976) argues that the intention for sacralisation is not only to protect the existing system of meaning but also to legitimise changes. In the case, the management committee is not only attempting to prevent future demolition and relocation of their community temple. They are also attempting to claim the new location as the permanent place for the temple. I further argue that the participation and support of the members of the local Hindu community are crucial for the management committee's endeavours. Morever, it is worth recalling that the management committee of the previous estate temple had not performed any ritual of relocation. As mentioned, when the managmeent committee was required to move out from the former location, only two members of the community (Bala and Maaran) were there to help with the relocation. Hence, this section is important to analyse further the important roles of the members of the local Hindu community in sustaining this temple as a social institution. The outcomes from the spatial claim with the plan of building a new Agamic temple, and the Balathanam ceremony in this case suggest a possibility of a different outcome for the temporary estate temple. I analyse the sacralisation process for this case through performance of ritual and rebuilding a new Agamic temple. 


\subsubsection{Ritual performance for relocation and spatial claim of the new location}

While the management committee was still in the midst of negotiating with the state government in obtaining the land ownership, they were suddenly asked by the developer to move out from the temple, to which the management committee had consented. As a result, the management committee of this temple had performed the three-day Balathanam ceremony for the relocation of the temple. The significance of the Balathanam ceremony is two-fold. On the one hand, the ceremony comprises a series of rituals to sacralise the temporary place. On the other hand, this ceremony was seen to be important in obtaining the Goddess Mariamman's consent to reside in the temporary building while waiting for the construction of the new temple to be completed. In this section, I analyse the importance of the Balathanam ceremony, especially for the management committee and the Indian Hindu community of which the temple served. This ceremony not only helped both parties to make sense of the demolition and relocation of their community but has also helped the management committee in transforming the developer's early request of relocation into an opportunity for the spatial claim. It has also helped the management committee to reaffirm their social position as members of the management committee as well as patrons of the Goddess Mariamman that is being housed in the temple. As part of my analysis of the importance of the Balathanam ceremony, I begin this section by examining the participants' narratives about the sakti of the Goddess Mariamman of this temple and the sacredness of the temple. The data for my analysis comprises interviews, informal conversations and observations on the series of rituals conducted for the ceremony.

I met Gowri, the wife of a member of the management committee during the first night of the Balathanam ceremony. She said, "They [the developer] said they need the space as soon as possible. Otherwise, their project would be delayed. We understand." Hence, moving out from the location before the completion of the new temple had required the management committee to perform the Balathanam ceremony. As a recapitulation, one of the fundamental reasons for the smooth demolition and relocation processes of this temple is due to the conformity showed by the community members to the management committee. This willingness in submitting to the decision of the management committee had also been 
one of the stark differences between this and the previous case study of the estate Hindu temple. As mentioned in the previous chapter, the Indian Hindus from the estate had regarded the decision made by the management committee to have their community temple demolished and relocated as a form of betrayal. Nevertheless, it is interesting to note that the Indian Hindu community for this case study has adopted the rhetoric of the management committee that the demolition and relocation is inevitable. Their conformity to the decision of the management committee raises the question of how the temple is important for them.

It is important to note that the participants from the community members of this case study had given similar statements about the importance of their community temple as the participants from the estate temple. These descriptions often revolved around how the temple before the demolition had been connected to their childhood memories. I have met many worshippers, who claimed that they had been visiting the temple since they were young. Their parents were or used to work as council workers who lived in Kampung Jawa Baru, and the place of worship had been known as the council workers' temple. In one of my visits, Ramani pointed to a spot at the construction site and told me, "I used to stay here when I was small. When I opened the front door of our house, we would see this temple in front of us. Every morning I would be awakened by the temple's bell. I did not need an alarm clock. The temple's bell is my alarm clock." Ramani's childhood memories about the temple and its location have suggested how the temple had been important to her on a personal level. A worshipper told me, "I have known all of them [the members of the committee] since I was a boy. My father knew them. After my father passed away, I still come here." He also pointed to a teenage boy and said, "That is my son. I want him to volunteer in this ceremony [of relocation]." From the above descriptions, their memories of the temple's histories had implied their attachment and level of dedication, which they have been trying to pass on to the next generation.

Moreover, the participants of this temple also believed that the Goddess Mariamman residing in the temple is a living being that protects their safety and well-being. A worshipper of this temple once claimed, "people here sometimes can hear the sound of 
[bangles as the Goddess was] walking." Apart from the sound of the bangles, another worshipper even claimed that he had a story about seeing the Goddess in real form. "My friend, who is also a committee, his daughter was very sick. He took her to the hospital, but she is not getting any better. It was about 11 something at night, he and his wife were sitting on the staircase outside his house, outside the house. A lady came by holding a basket and saw them. She told them 'don't worry, your daughter will get better very soon.' The next morning, the daughter okay already." Manikam also told the story of how the Goddess Mariamman had helped in curing his grandson. "My grandson got into an accident and fractured here [the rib cage]. He was admitted to Lam Mua Ee hospital. On the second day, about 11 something at night, as he was watching the TV [in the hospital room], he felt somebody was standing beside him. So, he looked, he saw one lady with long hair was standing beside his bed. He got frightened and shouted for his mother, 'Mother!' The lady disappeared. He is okay now." The stories from the worshippers had reflected how they believed the Goddess Mariamman had transformed into an actual form and protecting them. Their experiences about the divine intervention by the Goddess that helped their family members in their predicaments and as the life-saver of their family members have suggested their devotion to the Goddess.

Therefore, it is precisely the temple's significance, where generational memories of the community were established and the sacredness of the temple as the abode for the Goddess that make the Balathanam ceremony important. It is noteworthy that the participants from the estate Indian Hindus had claimed that the management committee had failed in seeking the Goddess Kaliamman's consent for the relocation of their community temple, thus, resulted in the community's refusal in acknowledging the temporary temple as an abode for the Goddess. I suggest that the management committee of this Mariamman temple has recognised the importance of the Balathanam ceremony as not only to appease and to obtain consent from the Goddess Mariamman. The ceremony was also to demonstrate to the worshippers that they had obtained the Goddess' mandate for the relocation. Furthermore, such display that the Goddess was willing to be relocated further reinforces the notion that their decision to comply with the government was voluntary. 
From my analysis of the previous case study, it makes sense that the management committee of this temple is ready to perform a series of elaborate and meticulous rituals that lasted for three days. Siva explained that the ceremony could be equated to the twelveyear Kumbabhishekam ceremony where the deity would be carried out from the (raja) gopuram. Then, the priests would perform a series of paramesvaraprityartham rituals to appease the deity before the latter is being transformed into a little girl. Siva explained, "The ceremony is a way that you get the blessings [from the Goddess] before you can move them. When we move the deity from one temple to another temporary [temple], we make the grown-up deity into a smaller girl. Bala meaning for Indian is 'little' like young. We believe the deity is becoming a young girl now [after relocation into the temporary temple]. When she moves to a permanent temple, then she is an adult again." This interview with Siva was held after the Balathanam ceremony and at the temporary temple where the statues of the deities are currently residing. "We believe, even now, the deity is a young girl." I asked, "Even at this moment?" He said, "Yes. When she moved to a place [the new temple], then she is an adult."

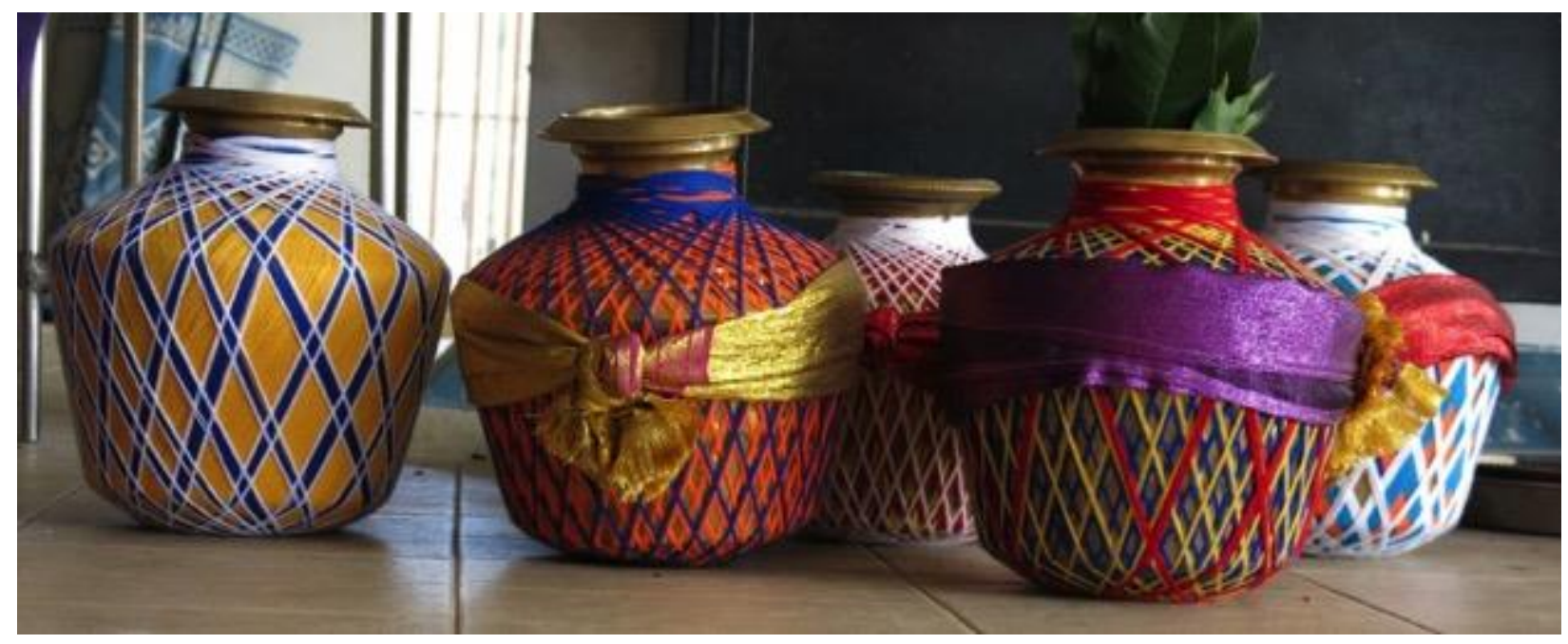

FIGURE 6 ESSENCE OF THE DEITIES IN SACRED VASES

After transporting the vases with the essence of the deities to the new location, they are placed outside the temple, as part of the final ritual. Following that, the management committee and the priests participate in the ritual of transporting these vases containing the essence of the deities from the former temple into the temporary temple (Photo from fieldwork). 
The elaborate and meticulous three-day rituals involved many sacred items. These items include a cow and a calf, banana-plant huts, an altar that was decorated with coconuts and flowers for the statues of the deities prior to being placed into the temporary temple, makeshift fire pits located at the entrance and four corners of the temple, a large tent with tables and chairs for the worshippers. The management committee had hired eight experienced and qualified priests. The preparations and organisation of these rituals had certainly strained their already limited financial resources. Siva said, "All that comes with money, dollar and cents. There was no help. For your information, we had spent close to RM30,000 [approximately NZD 9,500] for the function." Most of the expenses were spent on hiring the priests. "The priests are now very expensive. They are from Ipoh and all these places. You got to prepare for them the hotel ..." The expenses in hiring the priests were close to RM11,000 (approximately NZD3,900). The function appeared to have incurred additional costs on their already strained budget in building the temple. Siva added, "If you have a lot of money you can even do it in five days or seven days or nine days ceremony. It all depends. But because of a shortage of funds and now people are all very busy with their work. We only had three days of function." Nonetheless, as it appeared, the management committee did not let the strained budget affect the three-day rituals, which further reified their belief in the importance of the Balathanam ceremony.

One of the reasons that the management committee believed the Balathanam ceremony to be important is precisely due to the implication of the relocation. As Siva had mentioned earlier, the ceremony had involved transforming the Goddess Mariamman into a "little girl". The description of the "little girl" had denoted a decline in the sakti of the Goddess. According to the priest, "This year we will not have fire-walking. Before this, we have firewalking every year, now we can't organise that ceremony. We have to wait for the new temple to be completed because the Goddess is just a baby now, she is not strong enough." 5 As a result of the deity's inability of manifesting its sakti to the fullest potential, the temporary temple had received fewer worshippers as compared to before its relocation.

${ }^{5}$ Translated from: Kali ini tak ada jalan api. Tiap tahun ada, tapi sekarang tak boleh. Mesti tunggu sampai kuil sudah elok baru boleh buat. Dia tak kuat, macam baby. 
This outcome had affected not only the function of the temple as a place of worship for the community. It has also threatened the social positions of the management committee. Hence, the Balathanam ceremony would give the management committee an opportunity to reinforce the importance of the temple to the community even after the relocation.

The management committee had to attract the participation of as many worshippers as they could bring together in transforming the Balathanam into an opportunity with positive outcomes. Rituals that are performed in a temple could enhance attendance to the temple and subsequently strengthen social relations and communal ties (Baumann 2009, 174). During the three days ceremony, I met with many worshippers and the other management committee members who have attended the ceremony. It seemed to me that the management committee had succeeded in their mission. However, Manikam had expected a larger turnout. "On the first night, it was raining; I think that's why lesser people come. I think we only see 300 to 400 people in the first two days." Siva also opined that the reason there had been fewer attendees was because of a lack of publicity. "If we had advertised more we can easily see about 1,000 people."

Although the number of worshippers who came on that day was below their expectations, for an outsider such as myself, the sight of the rituals that were accompanied by the communal worshipping of the priests and worshippers had reflected the importance of the temple. Some worshippers even said that I was lucky to be able to witness and participate in the ceremony as it was one of the most important ceremony for the temple. The worshippers consisted of groups of families and relatives. Ramani took a day off from her work to attend the ceremony with her son, with the latter offering to help the priests in the preparation of the rituals. "I have known this temple since I am young, I want my son to help them as much as he can." Another worshipper said, "I have known this temple since I was small." He has moved out from the area since he married a few years ago. Nonetheless, as he also perceived the Balathanam ceremony to be an important ceremony, he had brought along his wife and two children to participate in the ceremony on the second and third days. The close-knit communal relations are demonstrated throughout the ceremony. The importance of the temple and the close relationships among the worshippers that 
included the management committee had shown that they had succeeded in achieving their objective of reinforcing the importance of the temple for the community.

The first two days of the Balathanam ceremony were mainly focused on the vigorous purification rituals. The rituals included the eight priests performing simultaneous rituals in the purifying of altars in the temporary temple, the huts outside the temple, all four corners of the temporary buildings and the path on which the deity would travel from the old temple to the temporary one as well as using the cow and the calf in transporting the statues of the deities. The purification processes had involved bonfires, chanting of mantras and with the chairman and his spouse receiving blessings from the deity that signified consent for the relocation. Then, a hired band of four musicians played drums and flutes as they travelled to every corner and around the inner and outer locations of the temporary temple to connote the completion of purification rituals. According to Clothey $(2006,48)$, rituals are important to assert boundaries symbolically. The way the management committee had invested in a series of purification rituals also suggested how they had sought to symbolically claim the new space, even though the DAP-led state government had yet to allow them to make a de facto claim on the land. Paradoxically, the committee's determination on claiming the new place had also reflected their uncertainty about the future of the temple, as they were aware that they had yet to own the land of the new location.

Therefore, on the surface, the Balathanam ceremony appears to be a series of rituals to sacralise the temporary location. As mentioned, according to Mol (1976), sacralisation requires four main mechanisms - commitment, objectification, myths and ritual - which were displayed during the ceremony. For instance, the Balathanam ceremony was comprised of a series of paramesvaraprityartham rituals to appease the Goddesses. The myths that surround the paramesvaraprityartham rituals have attracted many worshippers. Many scholars also found rituals and congregations of devotees to be useful in sacralising a place (Sheikh et al. 2012; Baumann 2009, 163-5; Michell 1977, 62; Turner $1979,17-8)$ However, Sheikh et al. $(2012,111)$ argue that intergroup conflict encourages the sacralisation process. However, in this case, it is apparent that the worshippers were 
keen to participate in the Balathanam ceremony that was initiated by the demolition and relocation of the temple. This is because the worshippers could take advantage of the deity's 'good mood' in the strengthening of their vows during her presence. Each ritual was announced prior to the priests performming the pujas. I also heard from a worshipper standing beside me that the priests were advising the worshippers to not focus on materialistic vows and she has also urged me to pray with them. This is especially apparent on the third day, as explained by Siva, "Basically, it is only during the Balathanam or Kumbabishekam ceremony that normal people can go near the deity. During regular days, the deity is inside the (raja)gopuram where only the priest can go in to perform prayers. It is only during rare occasions [such as during the Balathanam and Kumbabishekam] when we move the deity out." The temple had received the highest number of worshippers on that particular day. They had the rare opportunity of participating in the Balathanam ceremony and performing the darśan with the deity. Darśan is central to the Hindu puja (Michaels 2015, 254). Beckerlegge (2001) explained that darśan "implies both are beholding the deity and being seen by the deity" (62). By making eye contact with the deity, the worshippers believed that they would have a direct divination experience. It is also a way of uniting the worshippers in the most passionate and pragmatic ways and a way of rekindling the arccannai relationships between the Goddess and the worshippers.

Secondly, the elaborate and smooth Balathanam ceremony that constitutes a series of rituals had indicated the deity's consent on being relocated. The consent from the deity indicates another mechanism of sacralisation. The permission given by the deity had also suggested that the management committee has been managing the dramatic change of the temple in an effective manner. According to Mines $(2005,29)$, religious rituals are useful to assert control over territories, to garner social support and to articulate and contest hierarchical status within the community. During the three-day ceremony, the members of the management committee were often seen positioning themselves at the front of the altar and receiving special blessings from the priests during each of the ritual performances. The chairperson and his spouse, in particular, were the first to receive blessings from the priests. The usual worshippers were often observed standing near the edges and watching the rituals. During the shifting of the deity, the members of the management committee 
were assigned to carry the vases containing the essence of the deity to the temporary temple and placing them in the banana hut. After the priests had performed a series of rituals and the chantings of mantras, the management committee had to carry the vases inside the temporary temple carefully and remained at the sides while witnessing the reinstallation of the essence into the statues of the deity by the priests. Throughout these rituals, the worshippers were seen standing by the boundaries, hands in prayers and watching attentively. The smooth and successful process of the elaborate Balathanam ceremony had objectified the social positions of the management committee.

Apart from the objectification of social positions for the management committee, the success of the ceremony had also enabled them to demonstrate to the community that they had made the right decision in complying with the early relocation. During the Balathanam ceremony, Manikam has introduced Muthoo to me. Muthoo had accompanied me throughout the second day of the ceremony and explained the purposes of the various rituals that were performed by the priest on that day. He said, "I do not know about others, but I believe all that [the relocation of the temple] has been planned earlier before even we were born in this world. I could be wrong, but this is what I think." By referring to the Goddess' decision to relocate, it would have indeed been difficult for the worshippers to challenge such a claim. He further said, "We believe, She agree we agree. She agrees [first], then they [the management committee] agree. We [the worshippers] are not the person to agree." His brief explanation had summed up the power relations between the Goddess, the management committee and the worshippers. As a result, Muthoo had not shown any sense of resentment concerning the shift of his community temple since the Goddess had given her permission to do so.

Siva further implied that it would be wrong to blame or react strongly against the proposal to relocate the temple by the state government. "You cannot go around and say I did this ... I did this ... I did this ... you know. You are maybe just part of the things that had already been planned [by the Goddess]." Both Muthoo's and Siva's insights had seemed to imply that it would be too simplistic to assume that the relocation is mainly due to the proposal by the DAP-led state government and the temple committee's lack of authority (power) in 
opposing the request. In fact, the whole incident of demolishing and relocating the temple had been part of the deity's plan. During one of the breaks, one of the priests explained, "You see how we [the priests and members of the managing committee] was trying to carry the statue of Amma out from the temple with the cow? If she has not agreed to move, we would not be able to do it [to move the statue]. No matter how many people try to carry her, she won't move."6

Muthoo's and Siva's contradiction that it is the state government who initiated the request of relocating their community temple could be interpreted in two ways. Firstly, by refuting this claim, they were denying the fact that the management committee and the worshippers have been experiencing any sense of threats. Without the sense of being threatened, it would have been unnecessary for the worshippers to experience discontentment concerning the relocation issue. Furthermore, by denying the existence of any sense or forms of threat, Siva had justified in his mind that their act of conformity to the state government had not been an act of submission on their part. Instead, he seemed to imply that the management committee, the state government and the developer had all been sharing an equal playing field. Therefore, his claim is quite powerful in retaining the worshippers' confidence level on the management committee.

On the third day of the ceremony, the management committee had invited the state government to participate in one of the most auspicious rituals in the Balathanam ceremony. The state government had sent a representative to attend the ritual, a Member of Parliament (MP) of the area who happened to be a non-Hindu and a Chinese. Despite the different ethno-religious background of the MP, the management committee still invited him to join them in witnessing the instalment of the deity inside the temple. He had also joined with the members of the committee in carrying one of the vases that contained the deity's essence into the new temple. On the surface, the participation of the state government representative seemed to be an act of inclusion by the management committee. By accepting this honour given by the Hindu temple committee, the state

\footnotetext{
${ }^{6}$ Translated from: You nampak hari tu macam mana kita orang bikin, dengan lembu dan kami semua angkat dari dalam. Kalau Dia tak setuju, memang tak boleh angkat. Memang semua orang hari tu cuba angkat juga, kalau dia tak bagi memang tak boleh.
} 
government would be able to sustain and display their political power over the Indian Hindus (Appadurai and Breckenridge 1976, 207). Nevertheless, as Smith $(1992,103)$ argues that rituals can be instrumental as calls for attention, in which they are a process of marking interest. In this case, the ritual is a symbolic attempt by the management committee in binding the state government with the former's responsibility as patrons of the deity that safeguard the temple. They had brought to the state government's attention to the fact that they were marking their intention of staying in this new place permanently.

The participation of the representative could also be seen as an initiation of a reciprocal relationship with the Goddess. Appadurai $(1981,36)$ contends that an individual's share in a ritual process has a concrete content, which constitutes authoritative features for the individual. Indeed, it appeared that the management committee was giving the state government representative the privilege that is equivalent to theirs. The reciprocal relationship had also initiated the redistributive process of honours between the state government and the deity (Appadurai 1981, 35). For Hindu devotees in general, the redistribution of honours is a serious affair (Appadurai 1981, 37). It is important for the state government to uphold such a relationship, not with the management committee but directly with the Goddess of the temple. These transactional and reciprocal relationships between the state government and the deity have often been viewed as honouring and sharing (Appadurai 1981, 35). It symbolises a binding agreement between the Goddess and the state government.

Although the government representative had participated in the ritual of carrying one of the sacred brass jugs into the temporary gopuram, his participation in the ritual had ended there and then. He had not been invited to the earlier purification and paramesvaraprityartham rituals. Following the abhisheka ceremony, he changed back to his usual attire and left the temple, escorted by the members of the management committee. It was as though the management committee was ensuring that his participation had strictly been symbolic and by no means to indicate that they were sharing the management responsibilities or control of the temple with the state government. Instead, it is to establish the reciprocal relationship with the Goddess in a religious sense. As reflected 
from the fundamental religious objective of the Balathanam ceremony, the worshippers and the management committee had believed the nature of the sakti of the Goddess to be punitive. A substantial part of the ceremony is to appease the deity for the drastic change of her abode. The management committee's intention of involving the state government in the rituals, to bind as a way of binding the reciprocal and redistributive relationships between them were also ways to subscribe the state government under the punitive sakti of the deity. Their implicit agenda is that any future threats on this temple by the state government would also be a threat against the deity.

\subsubsection{Building the Agamic temple as a spatial claim}

As mentioned in the previous section, the management committee has been struggling to gain funds in the reconstructing of their temple, since the demolition and relocation of their community temple. Furthermore, they have not obtained formal entitlement on the new land. In this section, I argue that due to the engendered sense of insecurity, the management committee had insisted on building an Agamic temple to replace the former temple structure. I agree with Smith (1992) that the motivation to build a temple is not to create a sacred place, rather it is for political and social ends. A previous study by Kong (1993) has also suggested that building temples could also be a symbolic act of resistance to the authorities' encroachment on the Hindu's religious freedom. My analysis in this section had revolved around the management committee's sense of urgency in building the Agamic temple.

After they had relocated the statues of the Goddess and the deities in the temporary structure, my subsequent visits to the temple had given me the impression that the temple had only been receiving a small number of worshippers. The priest of this temple said, "Nobody comes today. Normal day, you could see people come [to the temple]. Now because the [new] temple is not completed yet, so no one would come. Wait, when the temple is completed, many people will come."7 The seemingly vacated temple had reminded me of the deserted estate temple from the previous case study. Although the

\footnotetext{
7 Translated from: Biasa hari, ramai juga, Sekarang tak ramai, kadang-kadang tak ada orang, sebab kuil tak siap. Masa siap, you mai, ramai akan datang. Sekarang memang tak banyak orang.
} 
members of the Indian Hindu community had not entirely deserted this temple, the priest has implied that they have been less keen on visiting the temporary temple, since the relocation. As I have suggested in the previous case study of the estate temple, the lower number of worshippers also indicated a disruption in the function of the temple as a religious centre. It is worth recalling that the desertion of the temporary temple by the estate Indian Hindu community is their way of demonstrating their discontentment with the management committee. As a result, their desertion has also indicated a threat on the social positions of the management committee. The volunteer priest of the estate temple had also claimed that the desertion by the estate Indian Hindu community had affected the sakti of the Goddess. It is apparent that the management committee of this temple has been cautious of the effect caused by the lukewarm attitude of the worshippers. As Siva had mentioned earlier, he has been aware of the unhappiness felt by a few people on their decision to demolish and relocate the temple. However, Siva was confident that, "When they [the community] see it [the completed new Agamic temple], they might change. When they see the new outlook of the temple ... They may not tell you directly, but deep inside their heart they might say, this is for the betterment of the temple." Since he is convinced that the new temple would help the management committee in retaining support from the community, he, therefore, saw the necessity of completing the temple reconstruction within the shortest time frame.

The project of reconstructing the temple has been an ambitious yet a desperate one. Despite having a lack of funds, the management committee had persistently pursued the project of constructing a new Agamic temple that would cost about RM 1.5 million (approximately NZD 480,000). They had even aimed to complete the construction within a two- year period. Siva, the project manager, said, “Usually, a Hindu temple's committee will take about ten years to build a temple. That is the period that would normally take to build a Hindu temple ... I do not want to drag this on for the next ten years or whatever. I am planning to finish it by 2018 and do the consecration ceremony by then, and I think it is a very short period." Siva's enthusiasm on completing the construction was also the reason for his appointment as part of the management committee by the senior members of the management committee. As discussed at the beginning of this chapter, the elaborate 
structure of a temple often suggests a higher class and caste backgrounds of the management committee and even the community. Siva said that the structure of the previous temple, although had appeared elaborate, did not follow the proper structure of an Agamic temple since it had started out as a temple for the labourers. "Because this type of temple is normally found in the estate, and without proper structure. The one that we will build, we will look into all aspect of our Hinduism and traditional way of doing it." Apparently, the relocation and rebuilding had given the management committee a rare occasion of building a proper temple as well as to eliminate any structural indications that linked it to be a labourer's temple.

The sense of urgency could also be because the temple had no land ownership on the new location. By law, the new land was still being owned by the developer. During the reconstruction of the new temple, the management committee had not received any news from the state government, the developer or the HEB about changing the ownership of the land to the temple committee. Manikam alleged that even though the developer had appeared to be willing to give the land to the temple, the matter had remained unresolved. ${ }^{8}$ As the temple had continued to be situated on the land that belonged to the developer, it is possible that they would be facing the same problem of having to relocate their temple again in the future. Due to this sense of uncertainty on the future existence of the temple, the construction of the new Agamic temple has suggested an assertive act of spatial claim on the new land by the management committee. The Agamic structure of a new temple could be their assertion as the rightful community in society (Younger 2010, 243; Clothey 2006 , 28). They had even intended to expand the function of the temple to increase its usage. At the new place, they had planned to build a hall that could accommodate at least 300 people. The hall would allow them to organise events and ceremonies, such as weddings. The intention of expanding the structure and the usage of the temple have further reiterated their act of claiming the new space. Presumably, the enhanced popularity and relevance of the temple for the local Hindus would make it much harder for the state

\footnotetext{
8 To date, there is no clear regulatory system in Malaysian law that addresses the procedure for application, registration and gazetting of land for houses of worship for non-Muslims (Sipalan 24 April 2014).

Furthermore, the developer has to apply to the state government to change the use or to subdivide the land (Penang Economic Monthly 2009).
} 
government and the developer to demolish and relocate the temple again in the future. Hence, by enhancing the temple's functionality and usage, the new Agamic temple would enable them to re-mark their communal boundaries.

The management committee transformed the demolition and relocation of their community temple into an opportunity to indicate their strategy to protect their community temple. Their acts demonstrate how they may not necessarily confront the government. Rather, their conformity and compliance appeared to be effective in prolonging the existence of the temple, at least for now. Besides claiming the space by building a concrete Agamic structure for the temple, the management committee also had the opportunity of a spatial claim through ritual. Such an opportunity arrived when the developer asked the management committee to relocate their community temple before the complete rebuilding of the new temple.

\subsection{Conclusion}

The success of this case study is because the DAP-led state government had played an effective role as a mediator in the negotiation process between the management committee and the developer. The developer had agreed to allocate a new location for the management committee to rebuild their community temple. They have also built a basic temple structure for the temple committee. I have suggested that the success of demolition and relocation of this temple was mainly because of the compliance of the management committee and members of the Indian Hindu community, on the one hand. On the other hand, the DAP-led state government had the intention to register the temple in the Hindu

Endowment Board. The interweaving factors - the relationships between the management committee and the devotees that frequented this temple; the improved socio-economic status of the management committee and the location of the temple - have formulated the context for this case study that is distinctive from the previous case study of the temple in the estate.

This case study is also useful to reflect on the important roles of the members of the Indian Hindu communities in establishing and maintaining the political and social significance of a 
Hindu temple. In this case, the management committee had obtained support from the members of the local Hindu community. The interviews from the participants of the Indian community, in this case, had reflected their submissiveness to the management committee of the temple. They have also adopted the rhetoric of the management committee when displaying their sense of satisfaction with the new location and the plan of rebuilding their community temple. From the explanations given by the members of the Indian Hindu community, the effectiveness of the hierarchical institution has been mainly due to the seniority levels of the management committee members. Their long-term commitment to managing the temple had earned them respect from the community members. This compliant attitude had reflected their trust and respect of the management committee's decision, which suggested the effectiveness of the temple as a social and hierarchical institution. The effectiveness of the hierarchical social institution of this temple had to be continually reinforced and maintained, hence, making it all the more important for the management committee to safeguard it from being permanently destroyed.

In choosing to comply, the management committee and the Indian Hindu community have since expressed their satisfaction with the DAP-led state government's role of being a mediator that helped to establish an agreement with the developer. It is noteworthy that the management committee and the Indian Hindu community have attributed the willingness of the developer in allocating a new place and a new basic structure of the temple, is as mainly due to the effective role of the state government being the mediator of the negotiation process. Their positive attitude towards the state government has further convinced outsiders about their conformity to the hegemony of the state government. Furthermore, the Hindu Endowment Board had even invited the management committee to register the temple under the Board. The invitation by the HEB had further demonstrated the state government's interest in the temple, which is absent in the case of the estate temple.

It is also worth stressing that the DAP-led state government had not been the only government that had shown interests in the temple. Based on the historical accounts from the participants, political leaders from India and subsequently Malaysia, have also visited 
the temple. I have argued that the participants' claims of the historical visits by these political leaders have reflected the political significance of the temple due to its location in the urban area. Visits from the political leaders have been possible since the temple is situated in the city that made it easily accessible for the leaders. As the temple has been the social institution for the Indian Hindu labourers and the council workers, it would be an important political platform for the political leaders in gaining political support from the lower and working class Indian Hindus in Penang.

I have suggested that the invitation from the HEB had revealed the limits to the compliance activities of the management committee. They not only rejected the invitation by the HEB but also believed that it could be an attempt by the HEB to encroach into their autonomous management control of the temple. As a result, even though the management committee had complied with the temple demolition and relocation, they had no land ownership on the new location of where the new temple will be reconstructed. This fact had indicated a crack in their almost flawless performance of compliance and conformity. The firm refusal of the management committee to have their temple registered under the PHEB had revealed how they would rather forego the opportunity in obtaining the land in the new location due to their fear of losing autonomous control over the management of the temple. Their decision has also revealed the fact that their conformity and compliance are not their submission to the state government, but rather, they have been actively protecting their community temple's institution from the encroachment of the DAP-led state government. Furthermore, their decision had also indicated how they believed the temple institution to be more important than land ownership, although they have been aware of the persistent uncertainty that the temple would be relocated again in the future.

Even with the looming uncertainty of the temple's future, the management committee still intended claiming the new location. The Balathanam ceremony is an opportunity for such a spatial claim. Despite their financial constraints, the elaborate and meticulous rituals of the Balathanam ceremony had enabled the management committee to achieve at least four agendas. The first is to reinforce their social position and influence as the patron of the deity; secondly, to promote the sakti of the deity; thirdly, to religiously and symbolically 
claim the new land that still belonged to the developer; and finally, to hold the state government accountable by binding its relationship with the Goddess.

The rituals, narratives and rationale of the management committee and the community, in this case, had demonstrated a flexible interpretation of a sacred place. The sacredness of a place is socially constructed and hence can be relocated if the community can make sense of the relocation. Therefore, in this case, my analysis showed that in order to make sense of a sacred place, whether due to its establishment, demolition and/or re-establishment, it is necessary to gain the community's narratives concerning their social and political realities. To reiterate further my argument, I turn to the third case study in the next chapter - the temple in the container. 



\section{A container Hindu temple}

It is worth recalling from the previous two case studies that the compliance and conformity showed by the management committee and the Indian Hindus of the two temples had often demonstrated their powerless positions in being the minorities of the state. This is seen from their approaches that often constituted exhibiting submissiveness to the hegemony of the government that included idly waiting for the arrangement of relocation or additional financial assistance from the state government. In this chapter, I further suggest that the conformity and compliance approaches have shown by the management committee are not limited to displaying submissiveness. Instead, as a result of the different social and political contexts that existed from this case, the conformity and compliance approach used by the management committee can be regarded as proactively seeking effective political interests and intervention from the DAP-led government.

In examining other approaches to showing compliance and conformity proactively, I turn to the demolition and relocation of a Hindu temple that has been managed and taken care of by a family for two generations. This temple had been demolished by the Department of Public Works (Jabatan Kerja Raya or JKR), a federal government agency and not the DAPled state government. From a few of my visits, the statue of the Goddess Kaliamman had been temporarily placed in a two-window container until a suitable place was found by JKR for the family to rebuild their family temple. In this case, I demonstrate how the family has shown their compliance is at the minimal standard which the JKR has required from them. As they become convinced that the JKR would not keep the promise of relocation, they have given overt defiance signals to the JKR. According to Scott $(2008,26)$, these signals by the subordinates are often meant to convey meaning rather than to openly confront the dominat groups.

Because the family has been managing the temple exclusively, they realise that various proactive ways had to be taken as a means of defending the temple. These were indicated by the way the chairman of the temple, Kumar had been proactively seeking information and updates from the government about the relocation of their family temple. In this 
chapter, I demonstrate how the family had to demonstrate that the temple provided religious and social significances to not only the family but also for both the local Indian and non-Indian Hindus. The family also have to show that the temple has political significance for the DAP-led state government. I demonstrate how the family has also opened up their family temple during Deepavali celebrations, thus setting a stage for the DAP politicians in propagating their political agenda to the locals.

The context of this case study demonstrates the complexity of the issue of Hindu temples demolition in Penang. This is because the family's disappointment in JKR has shaped their pragmatic and tactical acts of conformity and compliance to the DAP-led government. Their approaches range from joining the DAP and allowing representatives from the DAP-led state government to use the temple as a political platform. Kumar has also demonstrated to the state government that his position as the chairman of the temple possesses social influence which is supported by an extensive local network- the two components, which are much needed by the state government in sustaining their political power in Penang. Above all, he is willing to use his social influence in assisting the DAP-led state government to gain more popular support from the local Hindu and non-Hindu communities in the area. His efforts also suggest to the DAP-led government and outsiders that his family's temple is an important social center in that part of the township. By allowing the state government to use the two-window container temple as a political platform, this family has shown an important example of how a Hindu temple, regardless of its shape and size, can be a useful source of political and social influence.

For this case, I also suggest the political use of ritual performances in making the temple, irrespective of its shape and size, a sacred place. As discussed in the previous two case studies, the demolition and relocation of the temples to temporary structures have affected the function of these two temples as places of worship. The management committees and the Indian Hindu communities of these two temples believed that the sakti of the goddesses in the temples have been significantly compromised. As described by the management committee of the temple for council workers, the Goddess Mariamman is a "little girl" residing in the temporary structure. Therefore, they would not hold any annual ceremonies 
until the Goddess is placed in a newly constructed Hindu temple. However, this had not been the case for the container-temple. The family continued hosting annual prayers and special ceremonies for the statue Goddess Mariamman even though the deity was still being kept in a two-window container. Their descriptions indicated that the sakti of the Goddess is still as powerful as before the relocation.

This case study is also important in suggesting that the sacredness of a Hindu temple depends heavily on the Hindu community that the temple serves. As I have demonstrated from this case study, it is important for the family to continue hosting annual events and special ceremonies at this temple with the aim of attracting participation from the local Indian Hindus in the area. This is because the involvement from the local Indian Hindus would help the family to prove to the outsiders, particularly the government, that their family temple is not only important for them but is also a significant place of worship for the local Indian Hindus.

I begin this chapter with the demolition and relocation of the temple. I analyse Kumar's change of attitude towards JKR when the relevant authority had continuously failed in allocating a suitable place for them to rebuild the temple. I also describe how Kumar sought intervention from the DAP state government through the hosting of the Deepavali OpenHouse celebration. Then, I discuss how Kumar and his family celebrated the Navratri festival at the container-temple as a way of attracting the local Hindus in joining their tenday festivities. The data for this case study consists of interviews, field observations, plus informal conversations with the family and the local worshippers who came to pay their reverence in the temple during the Navratri festival, as well as the participants who attended the Deepavali Open-house celebration. 


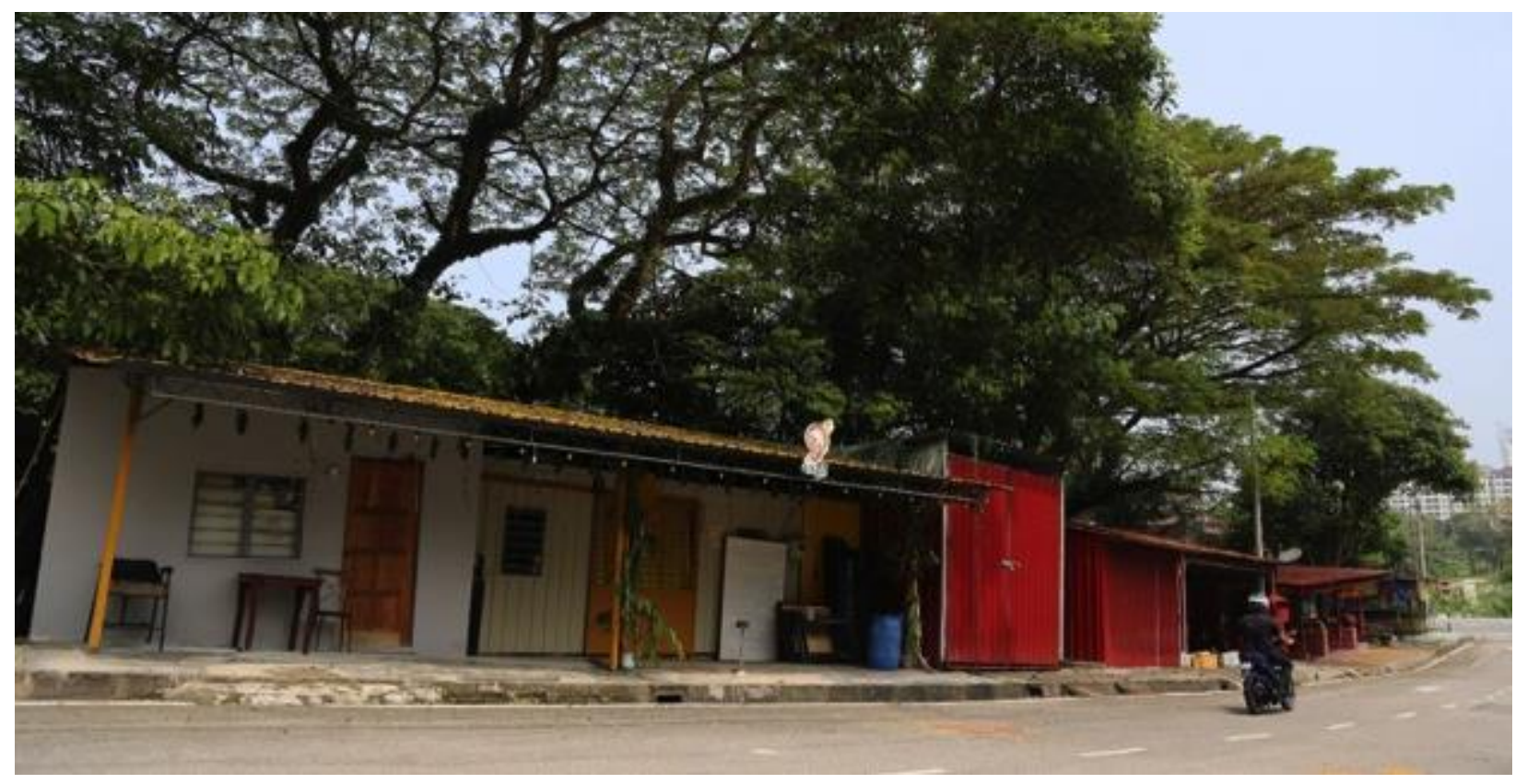

FIGURE 7 THE TWO-WINDOW CONTAINER TEMPLE

\subsection{The communal and religious significance of the temple}

I begin this chapter by analysing the historical background of the temple. I suggest that the historical accounts are given by the management committee often reflect their intentions and strategies in the fending of their community temple. Based on the accounts given by the family members from this case, I argue that they were aware of the possible vulnerability of their family temple since there could be a likelihood that the temple is perceived to be lacking communal significance among the local Hindus in the area. Their awareness, therefore, has formulated their intention in showing how their family temple as not only is important for them, but also for the Indians and non-Indian Hindus, such as the local Chinese. I also suggest that the emphasis on the local Chinese community's involvement that was mentioned in their historical accounts reveal their intention in safeguarding their community temples from being permanently demolished by the government.

According to the family, Kumar's mother discovered this temple at a Chinese village that was located close to their house. Ever since his mother passed away around 1993, he has been taking over his late mother's responsibilities in managing the temple and undertook 
the position as the chairman of the temple. Following the demolition and relocation of the temple into a two-window container by JKR in 2015, Kumar has stopped renewing the annual registration with the Registrar. However, he continued with his duties as the chairman, the caretaker and the priest of the temple. Since the demolition and relocation of the temple, he was the only one who has been actively seeking help from the government, while the other family members helped in funding the temple expenses by assisting in the administration of events and festivals.

The historical accounts given by Kumar's family on the discovery of the temple by his late mother have revealed three important points that attempted to emphasise its century-old communal significance to the local Hindus in the area. Firstly, they stated that the family did not establish the temple, but it had been discovered. "I did not ask much history about the temple. But as what I had known from the neighbours of the temple before my mother started taking care of this temple, there was one Chinese guy. They called him 'Jepun' [Japan], who was taking care of the temple. The temple used to be situated in a village that produced belacan [shrimp paste]. The village is known as Kampung Belacan. It was a Chinese village, and the villagers stayed there for a very long time, more than 100 years. They knew about this temple and had been taking care of it." Kumar's description of the temple's discovery that touched on the inclusion of the Chinese villagers further suggests his attempt to substantiate his claim of the temple being century-old.

Kumar's inclusion of the Chinese villagers also implies that he is aware of the possibility that his family temple being viewed as unimportant by the outsiders. "Many of them [the Chinese villagers] still come to this temple to participate in our festivals or special prayers. So, I think most of them believe in the god of this temple ... They believe in the god ... Because she likes to help those people who are sick or poor. When they come and pray, they will get whatever they request from the god. Not only the Chinese community, we, Indian people also believe this." Kumar's claim that the Goddess had answered the prayers of the Chinese community further demonstrated a reciprocal relationship between them. This mutual relationship signifies the devotion of the Chinese community to the Goddess Kaliamman in the temple. 
Secondly, this cross-racial validation could be particularly important for Kumar and his family to not only counter the perception that the temple had no communal significance for the local Hindus. It also suggests that the temple serves non-Indian Hindus as well. It is worth noting that based on the latest population census in 2010, about seventy-two percent of the population within the area where the temple is situated were Chinese (approximately 10,600 people), approximately seventeen percent of the population was Malay (approximately 2,600 people) and about eleven percent of the population was Indians (1,600 people)(Department of Statistic Malaysia 2010). Hence, the inclusion of the Chinese in Kumar's historical descriptions suggest his attempt in demonstrating the popularity of his family temple that is not only restricted to the local Indian Hindus. Most importantly, his attempt further suggests that his family temple, albeit having a small and simple structure prior to the demolition, had not been a Hindu temple for the minorities, but rather, bearing religious significance for both the Indian Hindus and Chinese.

Thirdly, the dream that Kumar's mother received also indicates that the family was appointed by the deity to take care and manage the temple. According to Kumar's sister, Kamini, "My mother's house used to be opposite of a small Chinese temple. One day she dreamed of a Chinese woman. She was wearing an anklet. She came to the front door of my mother's house. She said to my mother, 'Can you please come and pray for me?' The woman was wearing a dress in the colour of a monk's robe. When my mother woke up, she opened the front door and started praying. The Chinese woman in her dream said, 'If you have any problem, you come and pray to me'." ${ }^{1}$ Her claim that the deity could be a Chinese descendant reiterates the importance of her family temple for both the local Indian Hindus and Chinese. On hindsight, Kamini's narrative also suggests that the deity had appointed her family in the overseeing and management of the temple. The divine intervention that led to the discovery of the temple suggests how the family is appointed as patrons of the deity in managing the temple as her abode. By combining the narratives shared from the

\footnotetext{
${ }^{1}$ Translated from: This temple got lah the story. Very big story. First my mother. Her house last time opposite got small temple, Chinese temple. My mother, she mimpi, one Chinese lady, she put kaki loceng, she asked my mother lah, "nobody pray for me, you do lah for me." My mother, open the door, in front of my house. She pray. "You do for me, pray for me." Afterwards, go there, my mother saw lah. Chinese you know. Chinese woman. Pakai sami colour. Dia pakai. After my mother pray lah. If you got any trouble, you go pray.
} 
two siblings, the family argued that their smaller family temple has equal importance with the other century-old Hindu temples and those with religious divinity. Furthermore, it is important to note from Kamini's claim that their late mother had encountered a Chinese woman whom they believed to be the Goddess of the temple. This encounter indicated their belief of the Goddess as a living being, which is similar to belief shared by the participants from the previous two case studies. As I have argued in the previous two chapters, this belief in the Goddess as a living being has made the participants to be more willing in having their community temple demolished and relocated by the government.

Before the relocation, this Kaliamman temple was a simple structure with a small vimana at the rooftop that signifies it as a Hindu temple. As mentioned in Chapter Two, a traditional Agamic Hindu temple would have a vimana (the superstructure over the inner sanctum of a Hindu temple, specifically of South India's), a mandapa (a prayer hall) and at least one (raja)gorupa (a towered gateway). Traditionally, a vimana consists of a superstructure that rises above the garbhargha (Hardy 1995, 19). The superstructure is the most distinct identification of a Hindu temple (Michell 1977, 69). Its design often symbolises a mountain peak or 'crest' (Michell 1977), which Hindus believe symbolises a heavenly home that is raised above the earth. The garbhagrha is also known as the womb chamber where the statue of the main deity resides. It is believed to be the most sacred place, and only the priest is allowed inside.

Kumar sees the simple structure of his family temple as an advantage for the worshippers. Since this temple did not have a mandapa, the worshippers had been allowed to enter the garbhagrha for worship services. He said, "Sometimes they [the worshippers] came and sat inside the temple and meditate. They would feel peaceful." Kumar's family said that the temple had no (raja)gorupa that would barred outsiders from visiting the temples. Since the temple had been situated beside the main road, the absence of a (raja)gorupa has made the temple a popular site among bypassers, particularly tourists from different faiths and religious beliefs. According to Kumar's son Jaya, "because it was on the main road, many tourists would come and pray in our temple. A lot of Arabs, they came and watched us prayed, and some of them even prayed with us. We could get fifty, sixty sometimes 100 
people came to pray in a day." Hence, with the demolition of the temple, it not only involved the destruction of the vimana, but the popularity of the temple that was based on its initial location will also be compromised.

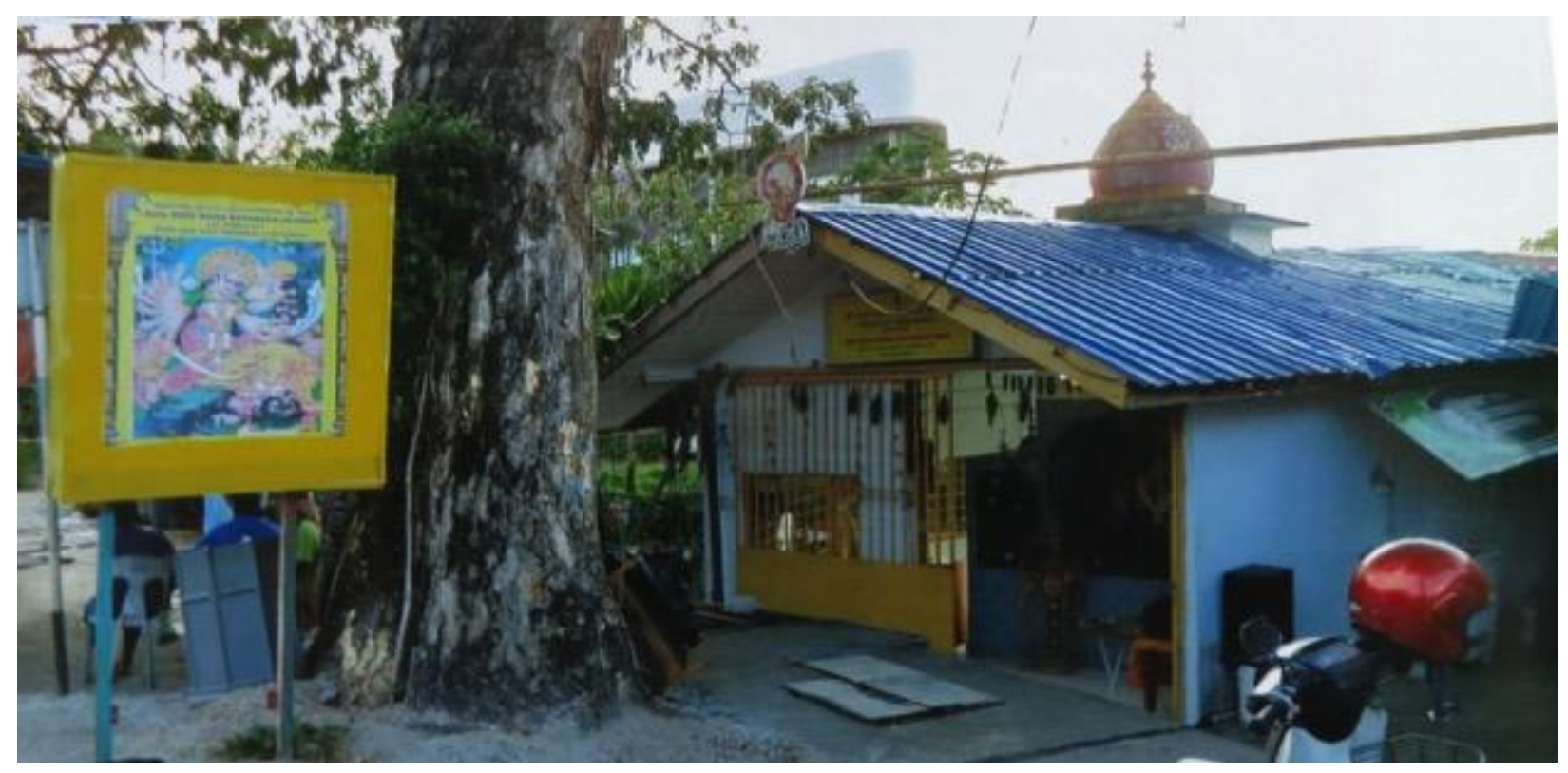

Figure 8 A PHOTO OF THE KALIAMman TEMPLE BEFORE DEMOLITION, TAKEN BY THE FAMILY (PHOTO SHOWN BY KUMAR DURING THE INTERVIEW)

\subsection{Demolition and relocation of the temple}

Despite the communal and religious significance of the temple for both the local Indian Hindus and Chinese, the processes of demolition and relocation have revealed how the family had initially shown compliance and conformity to JKR. I suggest that their initial performance of conformity and compliance to JKR had been tactical acts is revealed when the family became increasingly convinced that JKR would not be delivering what had been promised to the family - a new location for them to rebuild the temple and monetary compensation. I demonstrate how the family's tactical acts are revealed based on their change of compliant attitudes towards JKR. Above all, I demonstrate how the disappointment from the JKR has influenced the family's compliance and conformity attitudes and approaches to the DAP-led state government. Particularly, I analyse how their 
compliance and conformity to the DAP government are also their pragmatic and strategic acts to safeguard their family temple from permanent destruction.

This demolished Sri Kaliamman temple was situated at the heart of one of the most famous tourist spots in Penang. When I first visited the temple in 2012, I realised that its location had been within the reserved buffer zones of the river bank and the main road, which was deemed to be lawfully illegal. ${ }^{2}$ The river buffer zones are under the jurisdiction of JKR, a federal government agency. I remembered pointing out the problem of the temple location to Kumar. Kumar reasoned that the temple had been serving the Indian Hindu communities in the area for more than a century. Therefore, he did not expect the DAP-led state government would threaten to demolish the temple. When I visited the temple again in 2015 , the chairman had to lead my car with his motorcycle to a new location, which is about a kilometre away from the previous site in a residential area. A few months after our interview in 2012, a private developer had successfully acquired a large portion of land that included the plot of which the temple had been situated on. As a result, JKR has requested for the temple to be relocated.

The agreement between JKR and Kumar had been that the statue of the deity would be relocated to a temporary place until a new location is found by JKR for the family to rebuild the temple. Kumar agreed. "They just ask us, 'okay we need this place, you have to go ...' They offered us, they are going to give us a piece of land, and stated that they are going to give compensation to the temple." Apart from Kumar's compliance, this case seems to share a similar situation with the previous two cases - a promise of compensation by means of a new location and in monetary form. However, in the case of this temple, JKR had not built a temporary structure to house the deity. Since the temple demolition, Kumar has set up a two-window container for the temple at the new location that has been allocated by JKR. “We do renovation for this place. It cost about RM48,800 (approximately NZD17,000) just to buy the cabin; we do the building here, plus wiring electric supply and everything. The

\footnotetext{
${ }^{2}$ According to Section 25 (1) of the Street, Drainage and Building Act 1974, there should a width of not less than seven feet between the public road and any form of fence, plants or structure. The municipal council, has the authority and obligation to issue a notice for penalty and demolish the structure.
} 
JKR Pengarah [Director] of Penang signed the agreement because this land belongs to the JKR. When they move us, they said 'okay you can stay for temporary. We will provide you with everything; we give you money for the temple."' This incident happened around the year 2015.

For Kumar, to comply means being pragmatic. "If I against them, they will use force. They are the Land Department and the City Council. They will issue a notice of demolition, and then they will demolish. So, rather than let them come and just destroy the temple, it is better for us to agree to relocate. We have to give way to them." Such pragmatism raises questions about the sacred value of the temple. (Atran and Ginges 2012) has argued that when conflict is framed by competing religious and sacred values, the conflicts would last for years. They also contend that during the conflicts, the otherwise mundane phenomena (people, objects, events or even places) would then become existential struggles, as when land becomes holy land. However, in this case, Kumar appeared to believe that he and his family would be powerless in going against the government, even though he was unwilling to relocate his family temple. As I have suggested earlier, Kumar's claim of powerlessness is a performance of docility - pragmatic and strategic acts to ensure the JKR uphold the agreement to allocate a new location for him to rebuild the temple.

His expression of submissiveness is similar to the rhetoric used by the management committee of the estate temple. As discussed earlier, the estate temple committee used their rhetoric that suggested encroachment by the DAP-led state government, while for Kumar, his rhetoric has implied an encroachment from the federal government agency. He also said, "We have to give ways for the development. I have told the JKR, 'the temple committee will not interfere with the project, but you provide us with a place.' They said, 'Okay, you can come here and stay temporary; we will find for you.' Besides the land, 'They agreed to give us compensation of around RM88,000 [approximately NZD28,000]'." This form of conformity is similar to the rhetoric employed by the temple committee of the temple for the council workers in Chapter Five. Apparently, Kumar's willingness to comply was also because of the agreement made with JKR that the temple would be given a new place as well as being compensated in monetary form. With the promise of a new location 
and monetary compensation, it appeared that it had indeed been a strategic move to comply with the relocation of the temple instead of having it forcibly removed by JKR. His appearance of conformity also suggests that the initial negotiation process for this case had been carried out smoothly.

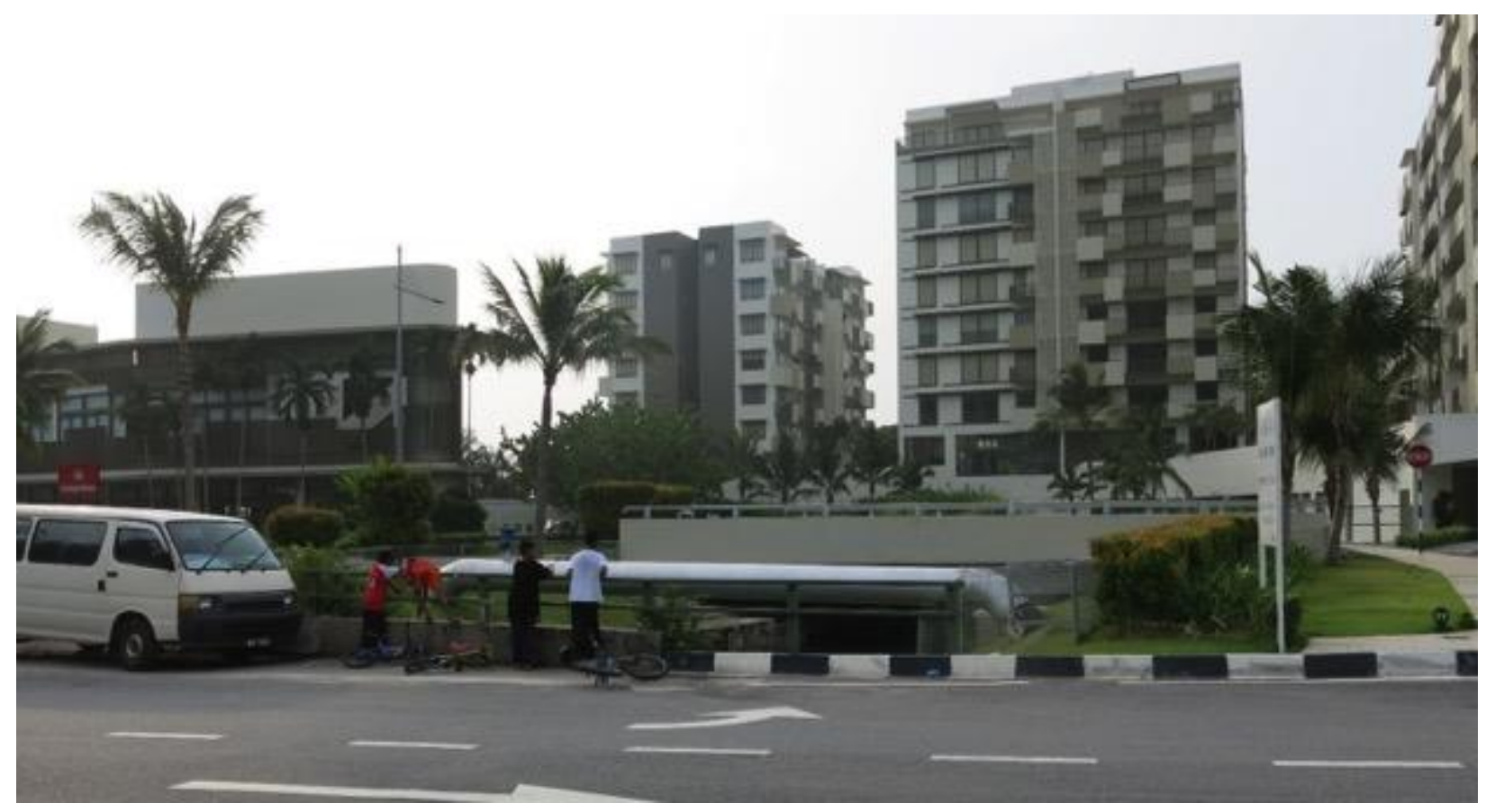

FIGURE 9 THE FORMER LOCATION OF THE TEMPLE AFTER THE DEMOLITION AND RELOCATION OF THE KALIAMMAN TEMPLE (PHOTO FROM FIELDWORK)

Since Kumar has given his consent for the demolition, he has initially believed that JKR would be upholding their agreement. "For the first year, they [the JKR] were all out. They go there, here, there. They called the RIBI [Rumah Ibadat Bukan Islam, translated as NonIslamic Religious and Culture Enclave]. They called this the Jabatan Bandar dan Desa [translated as the Town and Country Planning Department] to come down, and the Exco [Executive Councillor] members also came down. It was okay. I was happy because I thought maybe they could give us a place." In fact, JKR had suggested two relocation sites for the temple. However, it was precisely due to JKR's suggestions that Kumar's trust on the former began to crumble. He explained, "They give me a piece of land, it is an RIBI land, somewhere at the IVORY property, Miami Beach. Okay, first, it is far away from the residents [in the area]. Second, they give me a land which is not suitable to build a temple. 
The area is high up, on top of the hill. It is hard for the people to go, it is too far. There is a condo on top of the hill here. And to build a temple it costs around two million (approximately NZD712,000)." Based on his explanation, the first proposed location appeared to be different from what he had in mind. It would disrupt the function of the temple as a place of worship for the local Hindus in this area. The suggestion from JKR implied that the Department has ignored the important function of this temple. Kumar also indicated that the family would not have the financial means on building a new temple.

When JKR came up with the second proposal, Kumar became even more sceptical on JKR's sincerity in looking for a suitable place for the temple. He said, "They [the JKR] offered me a place somewhere in this area. Also, they call this a Boon Siew's corner. It is on top of the Indah Water [a sewage treatment plant]. So I say for the Indian temple or Chinese temple, they give a place somewhere at the Indah Water area." As he began to lose hope, his initial compliant attitude towards JKR had also changed. He began to declare openly that the Malay officers in JKR had racially antagonistic attitudes and had deliberately delayed the process of finding an appropriate new location for the temple. "You can see for all these mosques and everything, they are given a piece of land, empty piece of lands, quite big, somewhere in the residential areas. Why don't they also provide us with a piece of land somewhere in the residential areas?" This comparison of different treatments between Muslims and non-Muslims echoed Kumar's sense of being discriminated against. "... they thought our Indian or Chinese temples like rubbish ... You believe that they can do this to the Malay? To the mosque or the surau? No, they will find a place for them. Complete the building. Then they move. But here is nothing." It is apparent that Kumar's subservience has evaporated, and his insubordination has been revealed. He continued to imply that despite his compliance for the temple to be demolished and relocated, it is the Malay supremacist attitudes of the JKR officers that formed their disrespectfulness in the situation of his temple. His comments are his public repudiation that was hidden behind his compliance and conformity with the JKR.

The container-temple is situated beside two Taoist temples that are also in the form of containers. Kumar claimed that the two Taoist temples have been relocated there since 
2009. "Maybe this area is suitable for a temporary place," he said. It is not known who is responsible for the demolition and relocation of the two Taoist temples or when the incidents had taken place. This has shown that the issue of handling illegal temples that have been situated on private lands had not been limited to Hindu temples. Kumar also said, "You will see a lot of our temples, mostly our Indian and Chinese temples are situated on the government lands." His opinion has suggested the lack of studies conducted about the issues of Taoist or other religious buildings that have been situated on private properties. As his family temple was still in the temporary structure, it was apparent that JKR had not fulfilled the arrangement that had been agreed upon between the two parties. The former location of the temple has since been re-developed into a luxurious condominium complex. The very spot where the temple used to stand has become part of the decorated landscape with a large signboard depicting the name of the condominium. Meanwhile, the temple remained in the container.

Kumar's open defiance against the JKR suggests a breach of his initial performance of conformity and compliance. According to Scott (1990), incidents of breaching of public transcripts are rare, and its consequence is often manifested in "extreme provocation" and would often encourage a "conflagration of defiance" (214-5). However, in this case, Kumar's act of insubordination appears to be less extreme. Although he has broken his act of compliance with the JKR, he continued to display his powerlessness under the given situation. Kumar claimed, "Until today, the temple did not get any compensation or a land." He also argued that he had not received the monetary settlement from JKR. "I went to the meetings with the JKR two times. They said, 'Okay we would pay you.' In the end, now they wash their hand, they said, 'No, we cannot pay anything. Only we can give you saguhati [translated as consolation money]."' But now already three years. I keep writing letters to them. I have not received any response from the JKR. Even the saguhati also never get. I have all the letters, black and white, with me, the documents for this temple. Everything I have black and white, but no reactions from this JKR ... Now, I know that they play the dirty game behind my back." As a result of feeling betrayed, Kumar has also openly declared that he has no intention of moving out from the place on a voluntary basis. "I am not happy to 
move out from the old place. I am not happy." His changed attitude from compliance to discontentment reaffirms that the former pragmatic approach of compliance.

As Kumar became certain that JKR would not be seeking a suitable location for the temple, he became more open about his sense of loss as a result of his willingness in relocating the temple. He said, "I am not happy to move out of the old place. I am not happy ... Last time when I am there, I opened the temple from 6.30 to 12 noon. But, since I relocated the temple to here, I closed the temple at 9 a.m. because nobody comes to this temple after that. They come only in the morning for prayers, and then they leave. There is nothing." The drastic decline of visitors not only threatens the temple's function as a religious and communal centre. A small and family-owned temple with a low number of visitors such as this will also be questioned on the need for its continuing existence in the area. These possible consequences as a result of the temple relocation have reinforced Kumar's insistence on having a location that is visible and easily accessible by the local Hindus. Hence, the current site of the container-temple reflected Kumar's reason for rejecting the two new locations as proposed by JKR.

Kumar's concern about the loss of communal significance also reflected his awareness on how the Hindu community has been visiting the other Hindu temples that are located within the vicinity of the area. It is worth noting that there are about two other Hindu temples situated within the same areas. This an excerpt is taken from an interview with a devotee, "Do you know the Ayyah temple over there. That week they had a special prayer, and we [local Hindus] all observed vegetarian diet for a week. After the end of the week, they had goat sacrifice. We [local Hindus] all give offerings and food at the temple during the ceremonies." 3 The Ayyah temple is situated about one kilometre away, while another, which is a Chettiar temple, is located at a distance of about two kilometres. Apart from these two places of worship, located about five kilometres outside the border of the area is the famous "floating" Sri Singamuga Kaliamman Hindu temple. The temple is well-known

\footnotetext{
3 Translate from: Ayyah tau kah, sana saja kita sembahyang, kita macam, itu minggu makan sayur, ayah punya tokong, seminggu habis baru potong kambing tau kah, sana ayah semua taruh barang semua taruh makan, dia duduk.
} 
for its annual floating chariot processions that often attract many Hindus. Therefore, Kumar's family temple may not be the only Hindu temple that is being patronised by the local Hindus. Kumar's family temple is also different from the two temples that were mentioned in the previous two case studies, where they have been receiving regular worshippers who identified the places of worship as their community temples. Hence, Kumar's insistence on staying in the same area reflected his fear that the local Hindus would stop visiting his family temple. As discussed in the previous two case studies, the desertion or lack of worshippers of a community temple would affect the functions of the temple as a community centre that will subsequently threaten the social position of the management committee. For these reasons, Kumar realised that the temple had to stay within and among the local Hindus as a way of safeguarding the communal significance of the temple.

Kumar's attitudes towards the JKR have to be understood against the backdrop of the political context in Penang, for the meaning of a given action is socially and politically constructed (Scott 1990, 205). As I have argued in the previous two case studies, their nonconfrontational attitudes were meant to give the DAP state government no reason in violating the agreements made for the demolitions. In this case, however, Kumar's venting of his anger and frustration can be interpretated in at least three different ways. Firstly, Kumar's claim about the racial antagonism of the JKR officers suggested that he is aware of the on-going issue of Hindu temples demolition by the BN-led government. His allegations of being discriminated against by the federal government indicated that he also believed that the demolition of his family temple is a form of discrimination on religious freedom by the BN-led ruling government. His allegation of the JKR officers being racist is also his direct challenge for the department to prove otherwise, by finding a suitable location for his family temple. Secondly, it is also possible that his non-confrontational approach had not been useful in holding JKR accountable or it could be that he believed JKR would never fulfil the arrangement that had been agreed upon.

I believe the second explanation to be particularly convincing, based on his subsequent action of seeking help from the DAP-led state government. He said, "I am upset with the 
government because they have not fulfiled their promise. It is not the state government. It is the federal company, like the JKR." After giving up on the federal government agency, JKR, it is apparent that the DAP-led state government seemed to be the last resort for the family to seek help from. According to Kumar, his involvement with the DAP state government started way before the temple is demolished. This suggests that the family had been aware of the demolition threats made on their family temple prior to JKR's relocation request. Hence, this further confirms that their initial compliance with JKR's request had been a tactical move in obtaining a new location for the temple. "I have requested from our state government. And I also got a letter from the state government. I applied two times to ask for land. And I went for the RIBI meeting since 2012. Not only 2012, since 2009. I couldn't get a land until today." Apparently, even though he has been seeking help from the DAP, since at least three years ago, his attempts had not yielded any positive results. However, since JKR had let the family down, this explains why Kumar has continued in his optimism that the state government would help him. He said, "Our state government is trying to find a solution to solve this problem. And it was in charge by YB Jagdeep Singh. He is an Exco [Executive Council] for the local housing and also he is the chairman of the RIBI. He has helped us a lot. So, we are waiting for them to get a piece of land." 4 Jagdeep Singh Deo is the Penang State Executive Councillor (EXCO) for Housing and Town and Country Planning. His responsibility includes designating space for the construction of Non-Islamic Places of Worship (RIBI). Kumar had not mentioned the kind of help Jagdeep had given to the temple or his family.

Despite Kumar's claims that the state government has been demonstrating their intention in helping his case, he was also aware of the nonchalant attitude of the DAP-led state government. "The rule is saying that when you build a building, let's say a condo or anything; they should provide a piece of land for the RIBI, you see. But council keep quiet, never advertise this. If they got any Indian temple or Chinese temple, if you need a piece of land, okay we have a piece of land here, it is given by the developer to the council, and maybe you can use this piece of land as an RIBI land." This revelation indicates a crack of

\footnotetext{
${ }^{4}$ YB is an acronym for 'Yang Berhormat', a title for the state assembly persons and Members of Parliament.
} 
scepticism beneath the surface of his conformity to the state government. He knew that, despite his continuous request to the DAP-led state government, his appeal had often been delayed. However, since Kumar has chosen to rely on the DAP-led state government, he had not expressed any discontentment against the DAP the way he did with JKR. Instead, the lack of attention given by the DAP had further motivated him to be innovative in seeking the attention and political interest of the DAP politicians.

One of Kumar's approaches was to join the DAP. By joining DAP, Kumar might have appeared to be submitting himself to the patronising Malaysian political culture. However, Kumar's intention on being a member of the party was to be at the frontline of receiving information with regards to available land within the area, which he could then request from the state government. He said, "So, now I am into politics, alright? I have started to go to meetings to meet with the top people to get more information." While being interviewed, he pointed to a children's playground that is located opposite the temple, "This land belongs to a developer. When they built this condo, they allocated a piece of land for RIBI. But nobody knows this piece of RIBI land. So nobody requested. The council changed the title to a playground. You can see, it is quite a big land from here up to the end there. Maybe they can put three temples on the land. There is one Indian temple, plus two Chinese temples." Kumar was implying that his temple and the two Taoist temples could be relocated to that piece of land if they had known about its availability. If he had known about the land availability before it is converted into a children's playground, he would have been able to save his family temple by relocating it to that particular site. It is apparent that this important information had failed to reach the local non-Muslim communities. By joining the party, Kumar believed that he would not overlook any information concerning newly available lands again. His decision to join the party also indicates his foreknowledge that the DAP-led state government would not publicise such information if he did not actively seek the news from them. Hence, Kumar's decision to join the party also indicates that he is aware of the condescending nature in Malaysian politics. His conformity to this political culture is a pragmatic approach in obtaining upfront information from the government. 


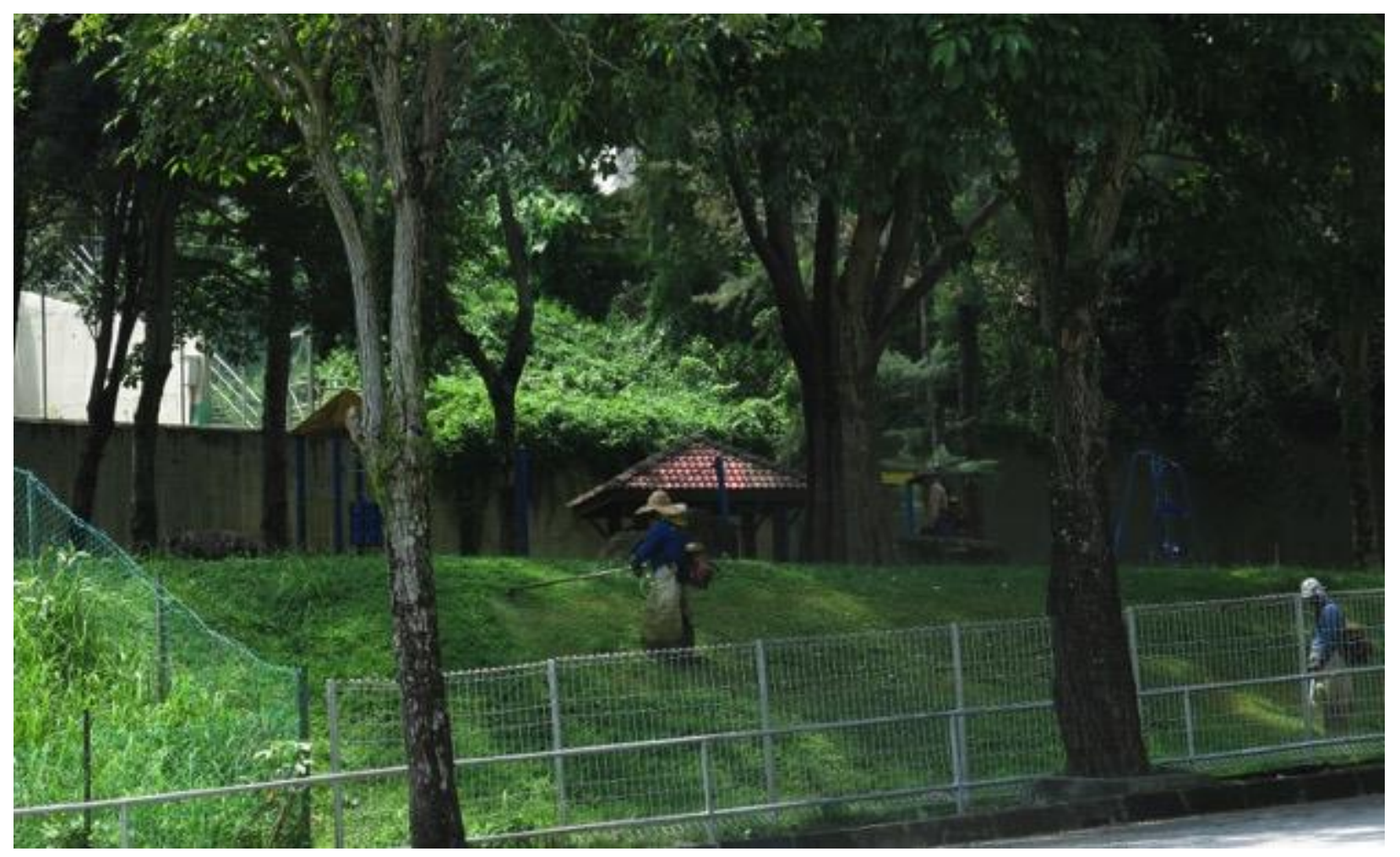

FIGURE 10 THE PLAYGROUND OPPOSITE THE TEMPLE, WHICH ACCORDING TO KUMAR USED TO BE ON RIBI LAND (PHOTO FROM FIELDWORK)

Besides obtaining information, Kumar believed that his involvement in politics would empower him to request for efficient help in gaining the land from the state government. Kumar said, "I went to the meeting on July 19, 2015. In the meeting, I told the officers of the local council, YB Jagdee, and our state assemblyman, YB Teh Yee Chiew, about the piece of land. They said 'okay we would look into this', I think after one month, they came, took photos of our temple and went there to look at the place, and they took a photo also. Yesterday I went to the land department to check for any updates about my request. They said they had not received any information for the time being." Since the officers had gone to examine the place, this suggested to Kumar that his involvement in the DAP has been an effective approach, although there had not been any positive feedback given on his application.

However, although Kumar's approaches have helped him to obtain useful information, it might not assist him in obtaining a new location from the state government. "I went for the 
RIBI meeting, I was there, and then I requested. They rejected my application before. I ask a piece of land, somewhere in this IVORY, there is reclaimed land, they denied and told me to find another place. So I request this piece of land, and they said they would look into this." 5 As seen from the above rejection, Kumar's confidence in the state government and his optimism in the latest application have reflected his desperate need for help from the state government. During the initial stage, however, it had not been clear on the kinds of contribution Kumar and his family offered to the DAP besides being a member of the party. How would his membership in the party help in attracting interests that are more political and subsequently grant his family temple the new land they so badly require? Kumar argued that it was possible to obtain help from the DAP state government without using any political leverage as a bargain. "You see, there is a Chinese temple known as the Golden Rooster temple. The managing committee has obtained land from the state government, somewhere at Jalan Sungai Satu, near to the Pinang Emas low-cost houses. It is an RIBI land, but they still have to buy the land from the state government. They have already obtained the land; we do not know when they are going to move." Despite not knowing the details, the successful relocation of the Taoist temple gave Kumar hope that his temple could gain a new land as well. His hope has encouraged him to continue with his quest of seeking intervention from the DAP-led state government in the relocation of his family temple.

Although joining the DAP is a pragmatic strategy, Kumar appeared to be aware of the situation that has been taking place within the party. For instance, I noticed that Kumar had not mentioned anything on Ramasamy's involvement. So, I asked if he had asked Ramasamy to help him in his case. Kumar answered, "Okay you see, the chairman of the HEB [Hindu Endowment Board] is a professor, the second Deputy Chief Minister. So he knows more about this. And I think most of my temple file is with him. On his table. Because any letter I sent to the council or any letter I forwarded to the government department, to the JKR, I will cc to Professor. So Professor also told me he is still looking for

\footnotetext{
${ }^{5}$ I went back to Kumar during my subsequent trip to Penang. He said that his application had been rejected with the reason that the RIBI department claimed that they had no jurisdiction to change the title of the land into RIBI land. Kumar said that he had to look for other land with help from the RIBI.
} 
land for the temple. I have already mentioned to him about my current application for the land over there. He should know very well. He attended the RIBI meeting. Okay, he got the letters, documents, and everything. So, I don't know how long I have to wait." His strong conviction of Ramasamy's knowledge on the case, followed by a subtle hint of Ramasamy's lack of attention on the issue, implied that he had no confidence that Ramasamy would help him if compared to Jagdeep Singh, the chairman of the RIBI. His different attitude towards both politicians reminded me of the political feud that happened between Ramasamy and the late Karpal Singh. Karpal was the national chairman of the DAP and also the father of Jagdeep Singh. ${ }^{6}$ The rivalry between them had been ubiquitously reported in the mainstream newspapers (Noordin and Yeoh 11 December 2011; The Star Online 26 June 2012). While Ramasamy publicly called Karpal the 'godfather', Karpal lashed back and called Ramasamy a 'warlord' (The Star Online 26 June 2012). In fact, the political rivalry became so severe that it had caused political faction within the party (The Star Online 22 March 2012). For Kumar, his confidence in Jagdeep was more on being practical than political, since Jagdeep, being the chairman of the RIBI, appeared to be able to help in the relocation of the temple to the RIBI land.

Kumar's actively searching for a land to propose to the state government is due to his desperate attempt in saving the temple from permanent destruction. "I know we cannot stay here for long. Because they are going to do a highway road. This road will turn into a highway. It is coming all the way from George Town to Teluk Bahang. There is a hill. They will call this hillside highway. It is our state government project. I think it will start in 2017." On the one hand, the mounting pressure explains how he has been actively seeking for new land to propose to the state government. On the other hand, he believed that he had to maintain a good relationship with the state government, but up to that point, his efforts had shown that his membership in the party might not have yielded the expected results. Therefore, based on the consistent refusal of Kumar's applications for new land, the state government did not seem to share the same sense of urgency as Kumar about the

\footnotetext{
${ }^{6}$ Karpal Singh passed away in a car accident, in 2014.
} 
temple issue. In fact, the attitude shown by DAP had a stark resemblance to the laidback attitude that was exhibited by JKR.

Kumar seemed to be aware of the seemingly lukewarm attitude of the state government. As a result, he had to look for another approach as well as to obtain stronger leverage in attracting more effective political interest from the DAP state government, and so, the annual Deepavali Open-House celebration had become a useful tool for Kumar and his family. In the next section, I turn to my analysis of this event as a means of identifying how it could help Kumar in his attempt of safeguarding the temple.

\subsection{Clientelism and partnership with the state government}

After interviewing Kumar, he has invited me to the annual Deepavali Open-House event, which he claimed his family has been hosting for many years. It was then that I discovered Kumar is a member of the JKKK (Jawatankuasa Kemajuan \& Keselamatan Kampung) for the state government in the area. This revelation has helped me to see the logic of how Kumar believed that by joining the party, he could establish political clientelism with the state government. As demonstrated from the case of Sri Kaliamman temple of the Byram Estate, holding a JKKK position would allow the community leaders to establish mutually beneficial relationships with the state government. Since Kumar has been one of the committee members in the JKKK, he also acted as a mediator between the grass-roots communities in Batu Feringgi and the state government.

My argument for this section is two-fold. Firstly, I argue that Kumar's efforts of supporting the DAP and showing compliance with the state government are neccesary as his surface appearance of conformity to the state government. As Greenhouse $(2005,358)$ quoted from Scott (1990), Kumar's support and conformity is a like a mirror in which the dominant might see themselves as glorified. However, "for those who hold up the mirror, the real action is on the other side of its opaqueness" (Greenhouse 2005). So, not only is Kumar required to show his support and loyalty to the state government, but the state government also has to assure Kumar that they would help him in the securing of grassroots networks within the local communities. These reciprocal relationships have been 
displayed during the Deepavali Open-House event, which took place at the containertemple as the designated venue. Secondly, for Kumar to hold the celebration at the temple, it also shows that regardless of its shape and size, the functions of a Hindu temple are versatile, since it can be used for other purposes apart from establishing and maintaining political and social influences among the management committees.

In Malaysia, a religious building such as the Hindu temple also functions as a platform for politicians to form and sustain political support from the Hindu community at the grassroots level. In this section, I further examine how the politicians have been making use of the temple in the container as a means of attracting popular support from the grassroots communities through the Deepavali Open-House event. I also investigate the reasons for Kumar in allowing the politicians to use his family temple as a platform for establishing support from the local people. Above all, I also analyse the usefulness of the Deepavali Open-House event that assisted Kumar and his family in seeking the DAP-led state government's help in finding a location for them to rebuild their family temple.

The celebration was held at the temple. To convince me that the event was worth attending, Kumar said, "I have invited the YB [Yang Berhormat, translated as the Honourable] to come. We will be giving out hampers for the poor people in this area. Not only to the Indians but all the poor people." The fact that Kumar was able to identify the poor households has suggested his familiarity with the local communities. He further said, "We will provide lunch as well. Usually, two to three hundred people will come to our open house." As he has anticipated a big crowd, he had requested for a couple of large canopies to be set up in front of the temple. The canopies took up a large portion of the street that is located in front of the temple. A stage as well as twenty tables, of which each can be seated by ten persons, were arranged under the canopies. Kumar has also hired for a food catering service. They also set up a large backdrop at the stage, featuring Kumar's portrait with a Member of Parliament and state assemblymen, whom I presumed would be the VIPs invited for the event. Beside the stage were two larger VIP tables draped in red tablecloths. Kumar even applied for the service of RELA (also known as Jabatan Sukarelawan Malaysia or 'The People's Volunteer Corps') in controlling the traffic. 
The Deepavali Open-House has demonstrated its importance for the family in hosting the event on a yearly basis. The event has given the family a reason for inviting their relatives, friends, as well as their current and former neighbours to the temple. On the day of the event, I shared a table with a family and their friends. An Indian woman who sat next to me told me that she has been receiving hampers from Kumar at every Deepavali celebration. She said that she is a Catholic and has been staying in the area for many years before moving to Tanjung Bungah, a town that is situated about 10 kilometres away. Kamini had driven her to the event. A Chinese family occupied the next table. They seemed to be friends of Kumar's family, just like many of the guests who attended the event. Prior to the event, Kumar and his two sons were observed to be busily arranging their gifts on the stage. As Kumar has expected, many people, including the young and old, came for the event. The large turnout of guests suggested the well-established networks of Kumar's family with the local people, who were not only limited to Indians but the Chinese as well. This fact has also reflected all, particularly to the politicians, of Kumar's indispensable role as a member of the JKKK. While waiting for the event to start, Kumar's family was seen anticipating the arrival of the VIP guests.

Besides giving the family an opportunity in strengthening communal ties with the guests, the family also took advantage of the situation by displaying their extensive networks with the local Indian and Chinese communities to their VIPs - the DAP politicians. Once the VIP guests arrived, they went from table to table and greeted the guests with handshakes. The reporters were seen to be busily tagging along and taking photographs. The other individuals who came with the VIPs were wearing T-shirts bearing the DAP logo. When the VIPs were seated at their designated tables, Kumar started the event with a welcoming speech, which was then followed by the free lunch. While guests were seen waiting for their turn at the food stations, the guests at the VIP tables were being served by waiters. Kumar was seen mingling around and greeting all his guests when he finally settled himself at a VIP table. When Kumar was going around, greeting the guests, I realised that he knew most of them by name and seemed to be very well-acquainted with the visitors. While Kumar was mingling with his guests, the VIPs (the politicians), were observed to be keeping to themselves. After about an hour of lunch, a VIP was invited to give a speech. A 
member of the Parliament went on stage and began by greeting the guests before continuing with his political speech. There was no mention on offering help for the situation of the temple. A few of the guests were seen to be paying full attention to the speech, while others continued with extra helpings of lunch and chatted among themselves in Tamil. After the speech, Kumar invited the VIPs to hand out the hampers. In Kumar's hand was a name list of over 40 people whom he has identified and recognised from poor households. While some of them eagerly received the gifts, there were others who refused to go on stage when their names were called out and had to be coaxed by Kumar. After each of the VIPs had taken their turns in the gifts distribution, Kumar then requested for the recipients to come on stage again for a photo session with the reporters. Some of the recipients left the event as soon as the photo sessions were completed.

The event is a show of clientele relationships between the politicians, Kumar's family and the local communities. Each party appeared to have benefited from the celebration. For the guests, many of them benefited from the gifts that were distributed. For the politicians, although the guests paid little attention to their speeches, they had the opportunity of making an appearance to the local communities. This further explains how they appeared to be content in carrying out their minor roles on that day. In fact, they seemed to leave the job of mingling to Kumar and his family members, who were busily entertaining the guests throughout the whole event. Nevertheless, these politicians seemed as though they had achieved what they had intended to accomplish from the event - the opportunity and a stage for their political speeches as well as photos taken with the grass-roots communities. Kumar has therefore demonstrated his crucial role as the bridge that links the clientele relationship between these two parties. For these reasons, it is important for Kumar to continue hosting this annual event. These local networks are deemed valuable for politicians, especially during general elections, and this is particularly true for the case of Penang. In the fieldwork conducted during the campaign period from the latest 2013 general election, I witnessed how a political candidate had established an extensive grassroots network that increased his popularity among the communities of Balik Pulau, which ultimately contributed to his win over the constituency (Teo 2014). The results from the 13th general elections further proved to the DAP politicians that they needed to establish 
and strengthen the grass-roots networks, which would aid in sustaining their positions in the state government of Penang.

It is a strategic move for Kumar to organise the event in front of the temple. According to Kumar, the politicians often accepted Kumar's invitations to participate in temple events. "Most of our political leaders. Like our MP and state assemblymen and state Exco members. They always come to our temple event. They join." This is because the events would give the politicians opportunities in propagating their political agenda while delivering their speeches on stage, as demonstrated by the Deepavali Open-House event, without violating the Peaceful Assembly Act 2012.7 Holding events at temples during festivals is considered to be a freedom of religious expression. By piggy-backing on the Deepavali celebration, the event has allowed the politicians to dodge the bureaucracy and limitations imposed by the federal government in propagating their political agenda. For Kumar, the presence of the state authority personnel at the temple also reinforced the perception that the temple is not only important for the family but the politicians as well. Although the politicians had not mentioned finding a new location for the temple, Kumar also did not use the event to gain support from the politicians and the guests who attended on that day. Nevertheless, the state government appeared to acknowledge the extensive grass-roots networks that Kumar has developed with the local. They even contributed money to co-host the event with Kumar. This support indicated that Kumar and his family had obtained an acknowledgement from the state government that the temple is also important for meeting the latter's political gains.

Furthermore, these events had provided Kumar opportunities in attracting visitors to the temple from both Hindus and non-Hindus. At the same time, he too could propagate the sakti of the deity in the temple. He said, "She [Amma] likes it. She likes a lot of people come to the temple. She always tells me that I should offer good foods for the visitors. That's why

\footnotetext{
${ }^{7}$ Based on the Peaceful Assembly Act 2012, Malaysian citizens have the right to hold peaceful public assemblies provided that prior notice is given to the police. However, the public assemblies exclude wedding receptions, funeral processions, Open-House events during festivals, family gatherings, religious assemblies and assemblies at designated places of assembly. Source: http://www.malaysia-today.net/laws-on-freedomof-assembly/
} 
I hired a good caterer to prepare these foods. Also, she likes to do charity for the people. So we are giving out these hampers." Apparently, the clientele relationships is also extended to the deity. Since Kumar has taken up the role as the patron of the Goddess, he claimed that the Goddess had directly requested him to be gracious and generous with the visitors of the temple. The close relationship between him and the Goddess is also reflected in Kumar's roles as the chairperson, caretaker and priest of the temple. The close relationship between them also demonstrated the exclusivity of the temple for his family. His acts of giving out gifts and providing free meals fit into the 'individuality' campaign, which is common in the Tamil culture. According to Mines $(1994,19)$, Tamil leaders are often obliged to portray good personalities, which include being modest and generous, possessing trustworthiness, as well as having dignity and honour. These individual traits are often contextualised and are based on the values and judgements of the community involved. Clearly, Kumar had established such a reputation of 'individuality' through the act of gift-giving. The act of gift-giving also gave the impression that he had a higher social status as the chairman of the temple. It is also worth noting that Mines' arguments also indicate the fact that such 'contextualised individuality' requires a consistent level of upkeep. In fact, Kumar has continued to justify that he needed to organise the event simply because the poor households needed his assistance. "Because you know, on a particular event, where through the temple we are giving a lot of contribution to the poor people. We never see the races. We have given these to the Chinese, Malay or Indian community. Something like we are giving them hamper and rice as contributions to the poor. In one year we are giving two times." The clientelism relationship between the deity and the people appeared to also strengthen Kumar's social position in the management of the temple. When he gave out hampers to the poor, it reaffirmed his high social status not only to the Indian Hindus but also to the other ethnic and religious communities.

By having the event at the temple, Kumar also had the opportunity to promote the location of the temple to the local Hindus and the other communities. Subsequently, the family could also accentuate the function of the temple as a social centre. Kumar claimed, "When a temple is established for quite long, you become more famous. It is like human also, when you are famous everyone will know. It is similar to this temple. You can see at the festival. 
There will be around 2,000 to 3,000 people will be attending." Hence, as Kumar had lamented that they barely receive any visitors as a result of the temporary relocation, these events would help in boosting the publicity of the temple. Although the number of participants who attended the event was smaller than anticipated, Kumar still had the opportunity of successfully promoting the location of the temple to these 200 people.

Kumar's organisation of the Deepavali Open-House event is a tactical move in the sense that he was able to demonstrate what he could offer in return for the state government's help in his case - the valuable and otherwise unattainable grass-roots networks and support from the local communities. It remains questionable as to whether Kumar would still finally obtain his requested land from this approach. However, the ambiguous attitude of the state government has given Kumar hope. The way they responded to Kumar's application on his proposed specific land has sustained his hope. Apart from the Deepavali Open-House event, Kumar has also persistently hosted the annual ten-day Navaratri festival at the container-temple. While the Deepavali event is to convince the state government that the temple was worth saving for political reasons, the Navratri festival was to convince the local Hindus that the temple and the deity had effective sakti that could help them in their well-being. The festival is Kumar's way of attracting and retaining devotion of the local Hindus. My analysis of this festival is in the next section.

\subsection{To maintain the temple as the communal and religious centre}

In my analysis of the Balathanam ceremony (Chapter Five), I argued that the management committee used the ceremony as a means of attracting more devotees to the temple. The participation of the mass devotees reinforces the sakti of the deity and reaffirms the temple as the emblem of their community. In this section, I analyse how Kumar and his family hosted the Navratri festival for a similar reason - to attract worshippers. According to Pintchman $(2015,4)$, a sacred matter "may actively shape meaning, human activity, and social relations in diverse contexts depending on the varying ways they are engaged, manipulated, and interpreted." I contend that the management committee often has diverse objectives for organising ritual performances in their community temple. Based on these objectives, the ritual performances have also been wide-ranging. In this case, for instance, I 
demonstrated how Kumar and his family had defied the conventional practice by hosting the Navratri festival when the deity is still being kept in the temporary structure. I also show how the series of rituals throughout the Navratri festival is different and localised at Kumar's family temple. The localised rituals further reflect Kumar's family attempts at establishing and maintaining the communal significance of their family temple.

It is important to note that in most the Hindu communities that I have visited during my fieldwork, the deities in temporary temples is generally considered as not manifesting their sakti to the fullest potential. One devotee told me, "We cannot do these [organising special ceremonies and festivals] very strongly; we will only do 'lightly' because, as I said, when we relocate, we are not that strong yet, just temporary only." Kumar's persistence in hosting the festival suggested that he intended to revive and restore the temple as not only a place of worship but also a place of gathering for the local Hindus.

Moreover, Kumar claimed that he had not asked for any support or help from others in safeguarding his family temple from permanent destruction by the government. The absence of help and support from the other members of the community has reinforced the temple's perception of being merely a family owned temple even though it is opened to the public. To safeguard the temple from being permanently destroyed, Kumar had to affirm that the temple is important for the religious needs of the local Hindu community even with the statue of the deity still being kept in a container.

In this section, I analyse how Kumar and his family have transformed the Navratri festival into another opportunity to emphasise their family's two-windowed container temple as a sacred place for the local Hindus. (Simmons and Sen 2018, 8-13) have also argued that the Navratri festival has complex interconnections between domestic and public spaces. The complexity of the interconnection between these two spaces is imbued with power and enmeshed with the issue of status. On the one hand, the Navratri festival when celebrated at home (domestic space), is grounded in symetrical relations between the family and the locale. Hence, the rituals of the festivals not only involve the family members, it also has the traditions of involving the participation of Hindu neighbourhoods (Simmons and Sen 2018, 10). Therefore, Navtratri celebrations are diverse in different places in India. Each 
celebration reflects the hegemony relationships at the local level. My analysis of the Navratri festival in Kumar's family temple also project the roles and functions of the temple within the dynamics of relationships at the local levels. This is one of the important reasons for Kumar and his family to host the festival annually, even though their family temple is in a temporary state. Furthermore, in South India, the festival is also a highly visible form of performance of social hierarchy within the Hindu community. The ritual performance reflects the negotiation of power relations between members of the community. Hence, I also examine the potential effectiveness of this approach. I further ask, how the family has continued to utilise the festival as a way of reinforcing their social status. Simultaneously, I will also demonstrate how a Hindu temple, despite its shape and form, can be useful in maintaining this social status. The degree of usefulness depends largely on the intentions and campaigns of the management committee. The analysis in this section is based on my field observations and interviews with the worshippers who participated in the festival. Through their interviews, I obtained their narratives on the sacredness of the deity that projects the temple's importance as an abode of the deity. Their narratives also reflected Kumar's important role in hosting the Navratri festival.

The Navratri festival is mainly to celebrate the victory of the Goddess Kali in defeating the demon Mahishasura. Throughout the first nine days, devotees worship three different deities. They believe that each of these deities possesses different sakti that protects different aspects of the devotees' well-being. Kumar told me, "First, they say there is a Lord Durga. There will be prayers for three days for Lord Durga. Lord Durga takes care of those in need. She is willing to help the poor or any people who need help and support. Lord Letchumi assists those with financial problems. Lord Sarasvati is more on education. She can help you to get more knowledge in the education." As described above, the significance of worshipping the three Goddesses is related to the uplifting of socio-economic conditions of the devotees. His particular emphasis on the poor who are in need of financial assistance and the importance of education for the devotees have indicated the significance of prayer among local Hindus, particularly to the deities in this temple. This explained the reason why Kumar and his family had to have an extensive preparation for the festival. For the nine-day celebration, Kumar and his wife had to juggle between preparing for the festival 
and their day-to-day jobs. Although Kumar is the temple priest, he has hired an experienced priest for the whole duration of the festival. He has also engaged the services of a food catering company and prepared the whole set-up of canopies, tables and chairs for the devotees who came for the rituals. Before the commencement of the rituals, Kumar's wife was seen to be helping with the preparation of ghee lamps, flowers and incense for prayers. The statues of the deities were lavishly adorned with sarees, flowers and ornaments. The face of the god was particularly painted in prominent bright colours according to each of the three deities that would be worshipped throughout the festival. The container-temple's inner and outer elaborate set-up have reflected the family's high anticipation for the festival.

The ten-day festival also gave reasons for the local Hindus to pray consistently at the temple. Their attendance throughout the ten days has further strengthened their communal relations. It is also apparent that not all came to the temple for ritual purposes. Kumar's relatives, as well as the worshippers from the neighbourhood, helped in the arrangement of flowers, chairs and food. While the adults caught up with each other and chatted about family matters, the teenagers and children were seen mingling and playing among themselves at their respective tables. I also noticed that some of the helpers brought food for the worshippers. Kumar's wife, Vasu, later explained, "They have stalls at the food court, so we ordered meals from them, to support their business." Their concerted effort in organising the festival had made the temple a lot livelier as compared to it being usually unused at most times. A worshipper, Magesan, who attended the festival with his wife told me, "Normal day I do not come to the temple, because I am very busy with work, and often reaches home feeling exhausted. However, this Navaratri we will sure come. To catch up with friends and neighbours." Kumar joined in our conversation and said, "Yes, I think we only get to meet once or twice a year, another time is during the annual festival, the firewalking." This conversation further reflected the usefulness of the festival in strengthening communal relationships, which is evident from the family-owned temple that has become a localised meeting place for the community. 
As Magesan indicated, even though the local community does not frequent the temple on a daily basis, it still serves as an important social centre for them. According to Aveling (1978), general attendance of such a localised small village temple for puja is often sparse. However, the community will turn up during festivals because of the social significance of the temple. It was during festivals that Kumar's family had the chance to demonstrate this localised function of the temple to outsiders. As Sosis and Alcorta $(2003,267)$ argue, the participation of worshippers in a ritual equates to their identification to the group. The festival has helped the family in demonstrating the temple's local importance, thus, highlighting the fact that it should not be permanently destroyed. Rather it should be rebuilt at a permanent site in the same area.

As the family recognised the importance of the festival to attract more worshippers to the temple, Kumar's family continued to work tirelessly in the festival preparation and ensured that the rituals go smoothly on the first day. Vasu told me, "Very tired. I had to work at the car wash from this morning until five o'clock. Kumar had to go to George Town to get the flowers and ghee lamps. I had to rush back here to prepare for the ritual. But it is okay, I am happy. People come, and they pray." Vasu's contentment with people coming to the temple suggested that the intention of organising rituals had not been only for religious purposes. David (2012) argues that special rituals and ceremonies can sustain a sense of belonging and identity through the expression of solidarity and group cohesion for the insiders. Vasu's response from the interview has suggested that the mere presence of worshippers on the first day of the festival had given a sense of recognition for this Kaliamman temple.

The turnout from the festival has also made it possible for the family in proving the Hindu temple's importance as a religious institution. Kumar said, "You must see how long the temple there, and how they run the temple. You don't want them just to build a temple, and nobody come and pray. The temple is left just like that." By hosting the Navaratri Festival, Kumar had the opportunity to restore the usage of the temple that has been affected by the relocation. Kumar said, "Over here, very quiet. Because this place is very isolated. Nobody would pass by here. Very few would come and pray now." His point of view clearly indicated his sense of loss, as a result, the temple's relocation. Kumar, however, had a 
different perspective. He said, "I am very disappointed because not many come to this [Navratri festival]. I know there are at least some two or three hundred Hindus in this area. But you see, they don't come and pray in this special festival." I asked if he knew the reason why they had not come to the festival. He replied, "I don't know, maybe they are not interested anymore. You see, that's why after I get a new place, I plan to build a hall beside the temple, to teach Hindu religion, especially to the younger generation." His explanation has again emphasised the need for rebuilding the temple, not only to safeguard his family temple but also to strengthen the religious beliefs among the local Hindu community.

The ten days of rituals have enabled the worshippers to strengthen their religious commitment to the Goddess Kaliamman specifically. During the rituals, the priest has summoned as many worshippers as the two-window container temple could accommodate. With the statue of the Goddess residing in the temple, the worshippers had the opportunity to get close to the Goddess and pay their reverence to her. As discussed earlier, Hindu worshippers rarely have the opportunity of getting close to the Goddess if the temple has a vimana (comprising a garbhagrha and a superstructure). Conventionally, only the male priests are allowed inside the garbhagrha, where the main deity resides. However, the large group of women worshippers seen teeming inside this temple were reciting mantras to the Goddess and receiving blessings from the priest. After the performance of the ritual, the worshippers approached the Goddess and told her their wishes. These acts of worship revealed their arccanai relationships with the Goddess. Arccanai is a reciprocal relationship initiated by the worshippers to the deity as a means of seeking divine intervention for crises, moving towards different levels of life-cycle and expressing gratitude for divine blessings and interventions (Appadurai and Breckenridge 1976, 195). The arccanai relationship through rituals reinforces the sense of belonging and identity through the expression of solidarity and group cohesion for the insiders (David 2012; Sosis 2004, 168; Sosis and Alcorta 2003, 267). As a result, the arccanai relationship anchors a local sense of belonging and a shared communal identification between the local Hindus and the family-managed temple. During the festival, the family also distributed sweet desserts of prasad (religious offering) to the worshippers. This distribution further cemented the arccanai relationship between the Goddess and the worshippers. 
For the arcannai relationships with the Goddess to be effective, the worshippers must also believe in the sakti of the Goddess. For Kumar, the Goddess Kali in his temple is one of the most powerful deities. "She has 18 hands because she has nine types of power. That is why they said she is Lord Kali. She will go for the hunt and fight and never afraid, and she will succeed. Most of the Indian people in India believe Lord Kali is one of the strongest in the world. She can do anything she wants. If you got any problem in your heart, whether it is about family, financial, or people or something that is harming you, like black magic. She can solve all these problems. She can also cure the sick." Kumar had intended to propagate this belief on the powerfulness of Kali during the Navratri festival. Kumar's sister, Kamini, has urged me to take a close-up photo of the deity's face throughout the ten days celebration. "You go and take her picture. Use your hand-phone and go and take her picture every night when you come. Then after all these are over, you go home, in your room, you slowly look through your pictures. You will see, her face changes. Every night she would look different. Really! I tried before. Last year."8 She then took out her mobile phone, "See?" She scrolled through three pictures of the deity as she showed them to me. "Her face will change as she is getting hotter because we continue to pray to her like this every night. She will become more and more powerful. On the last day, her face will turn black." ${ }^{\prime 9}$ At that moment, I could not help but wonder if Kamini was referring to the face paint on the statue of the deity. One night, as I arrived at the temple before the start of the rituals, I found the priest painting the face of the statue in bright pink. Then, he carefully outlined a pair of big eyes with black paint. These were done behind a curtain before the deity was ready to receive the worshippers. Nevertheless, Kamini's narratives and an invitation reflected not only her belief in the Goddess' sakti but also the importance of the devotees' participation in reinforcing the sakti of the deity.

\footnotetext{
${ }^{8}$ Translated from: Puan. I bagi tau, you pergi tangkap gambar dia. Guna hand-phone you. You pi ambik, tiap malam you mai, you pi ambik gambaq dia. Lepas tu, malam nanti, bila semua ni sudah habis. Malam you duduk seorang-orang, you perlahan-perlahan tengok gambar dia. You akan nampak, muka dia, tukar. Betui! Last year, I ambik gambar dia.

${ }^{9}$ Translated from: Muka dia akan jadi semakin garang tau? Sebab dia sudah jadi hot. Kita pray pray pray tiap malam, dia sudah jadi hangat. Hari last sekali, muka dia akan jadi hitam.
} 
In their attempts to reinforce the effectiveness of the deity's sakti, the narratives given by the siblings appeared to emphasise their beliefs on the deity as a living being. "Some Indian people believe that they cannot play the fool with this god because she is straightforward. When you do the prayers, you must be honest with her." As a living being, Kumar believes that the deity has full awareness of the devotee's intention. With her punitive sakti, the devotees must show respect and devotion. Kamini warned, "Whatever you asked for, she will grant your wish. However, if you have received what you have asked of her and never give something back in return, she will punish you by taking back what you have wished for. It is her way to remind you that you have not given something back in return. She could come to your dream. Of course, she would not harm you. She would just remind you that you have forgotten to give something in return for her granting your wish."10 This reciprocal personal relationship with the deity has ensured the worshippers' devotion to her, which then sustained the sovereignty of the deity. The punitive nature of the deity's sakti further cemented this relationship. Moreover, Appadurai and Breckenridge (1976, 191) found that in South India, the belief in the statue of the deity as a living person had qualified it to own properties known as tevatanam (gifts). Kamini's and Kumar's insistence that the Goddess is a living person also suggested that the deity is sovereign and therefore, deserves a permanent place for her temple.

The Navratri festival is especially important for Kumar because it consisted of a series of rituals that continuously reify the communal relations between worshippers. Throughout the ten days, I also observed that three to four women had performed the simple three-clap of kummi dance at the front entrance of the temple. Kummi dance is an ancient form of traditional folk dance of the Tamil. It originated when there were no musical instruments (Subhasree 2014, 50). For diasporic Hindus, the dance could be an expression of cultural identity and is not associated with the Goddess (Shukla-Bhatt 2015, 107). Kummi dance is called by diverse names in different parts of the state of Tamil Nadu and by different

\footnotetext{
10 Translated from: You tanya apa apa pun, you dapat you tak bagi balik, Dia [the deity] akan kasi you susha balik. Dia kasi you ingat balik, you ada janji sama saya, tak buat. Dalam mimpi pun dia boleh mai, you janji. Tapi tak aka kacau satu kali lah, Dia tunjuk apa yang you sudah lupa mau buat. You ingat balik.
} 
community. For instance, the Gujarati community calls it garbo dance. ${ }^{11}$ According to Shukla-Bhatt $(2015,92)$, traditionally, the garbo dance like kummi dance, is performed by a group of women. Shukla-Bhatt (2015) also argues that there have been no authoritative texts that mentioned the garbo dance as being in a specific way, however, the descriptions that mirror the garbo dance has consistently emerged in Gujarati traditions. When the women dance the garbo, the sacred boundaries are marked by their feet surrounding the garbo image, which signifies the sacredness of the whole world (Shukla-Bhatt 2015, 104). The kummi dance that was performed by the local Hindu women worshippers at Kumar's family temple were from different age groups. Although their dance would not have implied demarcating the sacred boundaries of the whole world, they certainly marked the sacred boundaries of the temple.

It is apparent that the Navratri festival organised by Kumar's family has attracted local Hindus with different communal background. A worshipper, Kuganeswary revealed, "They [Kumar and his family] are Malayalam, so they worship Kali. We are Tamilian, we do not pray to this Kali, but we pray to our own Kali. We are not the same. Some people worship Kaliamma; some people worship Mariamma. I am supposed to worship Mariamma."12 Kuganeswary's explanation reiterates the argument by Aveling (1978) about the significant changes in local Hindu village temples in Penang that occur over a period. Aveling (1978, 179) observes that the local Hindu village temples in Penang have often been places of congregation for Hindu devotees of different ethnicities and backgrounds. Evidently, such significance has experienced little change since Aveling's study. Kuganeswary also mentioned, "But, now you can go to any temple to worship. Like me, I can worship in this temple now."13 Nevertheless, the fact that Kuganeswary has brought up the different ethnic identities between herself and Kumar's family still implies the existing distinctions among different Indian Hindu communities, which is dismissed by the community.

\footnotetext{
11 For instance, Subhasree (2014) has listed Koppi in Andhra Pradesh, Kaikottikali of Kerala, Garbha dance of Gujarat and Ghoomar dance of Rajasthan.

12 Translated from: Dia orang Malayalam, dia orang Malayalam, Kali sembahyang. Kita orang Tamilan tak ada. Kita orang pun ada Kali. Semua orang serupa tak ada. Setengah orang Kaliamman sembahyang ada, setengah orang Mariamma sembahyang, Saya punya tokong Mariamma.

13 Translated from: You pi kuil tokong mana boleh sembahyang. Sekarang saya sini boleh sembahyang.
} 
Since the Navratri festival had to involve ten days of special prayers, the family had been able to attract the Hindu worshippers in joining the special prayers performed by the priest in their family temple. During the interview with Kumar, he continued to stress on the importance of the Hindu community adhering to the customs of the ten-day festival. He said, "On the final day, on the 10th day, we will take the statue [of Lord Kali] out from the temple, to fight the demon and kill it." It is on this day that the worshippers will carry Lord Kali in a procession. Some of the devotees would opt to place the deity in a chariot or to carry the deity in a palanquin; Kumar had chosen the latter method for the special ritual on the final day. After battling the demon, the male worshippers carried Lord Kali back to the temple. Before settling her inside the temple, the priest and the worshippers had to perform a bathing ceremony. The ceremony was to calm the wrath of the Goddess after the battle with sacred water made of rose water, turmeric water and milk. Then, the priest would dress up the statue again before it is being carried back into the temple by the male worshippers. Throughout the whole process of the ritual, women were observed to be following closely behind, fetching water and chanting mantras loudly. The ceremony had been carried out with a concerted effort from the priest, the family and the worshippers. Whitehouse $(2005,95)$ argues that a ritual that is low in intensity, which is performed not more than once yearly, is usually a very emotional event. 


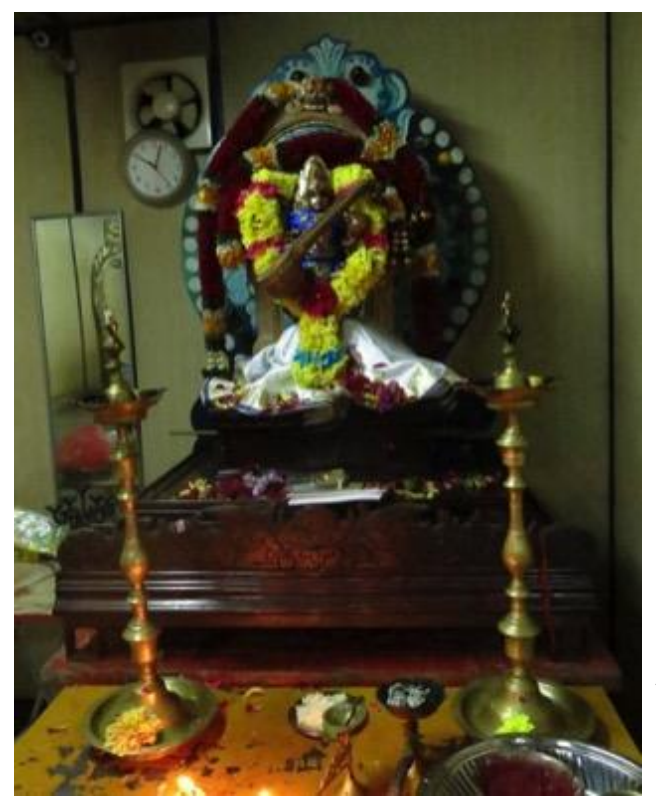

FiguRE 11 THE STATUE OF THE GODDESS KALI, WHICH WORSHIPPERS CARRIED OUT TO FIGHT THE DEMON ON THE LAST DAY OF THE NAVRATRI (PHOTO FROM FIELDWORK)
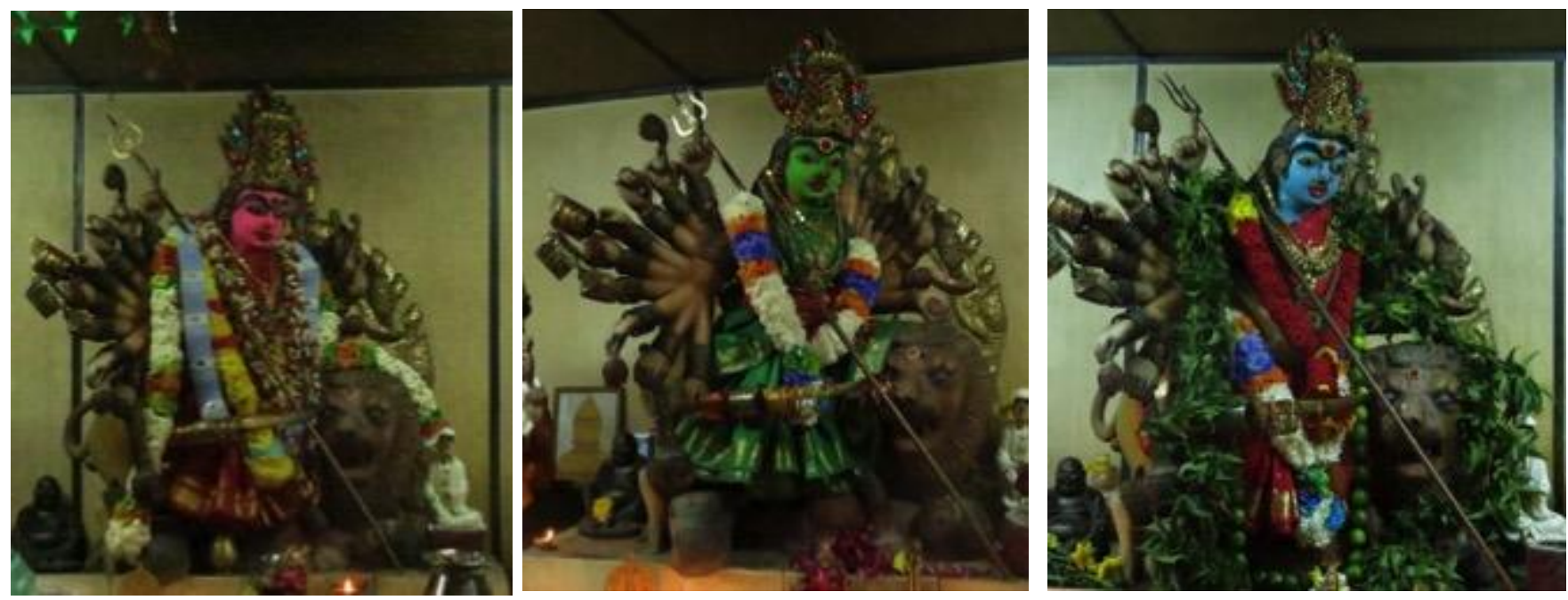

THE CHANGING FACES OF THE GODdESS KALIAMMAN DURING THE NAVRATRI FESTIVAL These three colours of the Goddess signify the changing of deities of worship during the Navratri festival. During the last day, the Goddess's face is painted black (Photos from fieldwork)

It is also apparent that the worshippers have shared similar narratives about the sakti of the Goddess. In the previous two case studies, the similarities in the narratives and accounts of the participants often indicated the existence of communal relations between them. As such, it is precisely these communal relations that Kumar and his family had intended to establish and reinforce through the Navratri festival. Their descriptions have also reflected their similar beliefs in the sacredness of the Goddess. The worshippers who 
came to this temple even shared similar stories about the sacredness of the Goddess. Dewani, who was one of the worshippers that came for the ritual with her friend, said, "[The Goddess is] very powerful. She sits on the lion. If you have any sickness, you come and pray to this Goddess. She will heal you." ${ }^{14}$ As I was interviewing Magesan about the temple, Ramani came and joined us at the table. Magesan prompted, "You ask her; she came to ask Amma for help to get her son a job. Now, her son has a job in Singapore." Ramani nodded with a smile. Since the deity had granted her wish, Ramani had come to participate in the festivals and the special ceremonies that were being held in the temple.

The similar narratives of the sakti indicated the fact that the temple had obtained a substantial acknowledgement of its religious and social significances for the local community. I was invited to sit with a couple during dinnertime. The woman said, "This temple very powerful, because whatever you wish you can get. Have you heard about the story of the Chinese auntie?" Kumar, Kamini, and a woman devotee, Kuganeswary had mentioned the story of the 'Chinese auntie' thrice throughout my fieldwork on the temple. She told me: "I have a Chinese friend. She came to this temple and asked, 'Amma, my leg become like this. Amma, please help me with my leg. I have gone to the hospital; the doctor said even the prescribed medication could not help.' She told me that Amma gave her turmeric powder, leaves and some white substance. She applied them to her legs every day. After her legs had got better, she started working."15 She said that ever since the condition of her leg has recovered, the woman has been coming to the temple to pray. "The following years, she came during the special ceremonies. She carried the milk; she followed the vegetarian diet. She offered the milk to Amma. Many people came to this temple. Really."16 Her final remarks are an attempt to persuade me into believing the sakti of the Goddess, which indicates that the sacredness of the Goddess also depends on the numbers of worshippers who are devoted to her. Furthermore, their emphasis on the story of 'the

\footnotetext{
14 Translated from: Sangat kuat. Tokong ini duduk singa. Kalau you sakit apa-apa dia boleh bagi baik.

15 Translated from: Dia tanya, "Amma kaki saya ini macam. Amma tolong lah, Amma tolong dia kata. Kaki ini macam. Saya hospital pi, doctor cakap ubat kasi pun tak boleh baik." Dia cakap kat saya "kasi kunyit dengan daun kasi. Putih gosok kaki, taruh punya kaki hari hari punya taruh dia boleh baik." Kalau sudah baik, dia pergi kerja.

16 Translated from: Lain tahun sembahyang besar dia mari. Dia mai angkat susu, dia makan sayur. Dia mai taruh Amma susu. Banyak orang mai ke tokong ini ah, betul punya.
} 
Chinese auntie' appeared to be justifying the fact that the Goddess is willing to help all of her devotees, including those who have just worshipped her for the first time. The story could also be the worshippers' means of debunking the deity's sakti as being a myth. For Kumar and his family, this story has reflected the important role of their family temple as an abode of the Goddess to the local Hindus.

Kamini continued in advocating the sakti of the deity by revealing that the family of the Chinese woman had also received much needed help from the deity. Kamini told me: "Even if evil spirits disturb you, she could clean it. The younger brother of the Chinese woman was working very far away. He opened a restaurant. His business was doing very well at first. However, his neighbour became jealous of his business and cast a curse on him. She was very sad about it. Not just the brother, but his whole family as well. The restaurant business became worse. She came and told me about her brother. So I took her to this temple and told Amma about what has happened to her brother. Amma said not to be afraid; she said somebody had cast a curse on him. This temple did some special prayers on a small statue of Amma and gave it to the brother to bring back to Langkawi, where his restaurant is situated. He was instructed to pray to the statue every day. The God cleaned the place and cured all his family. The restaurant business recovered. In fact, now the business of the restaurant got better. The next year, the family did special prayer at this temple."17 This story about the family of the Chinese woman has reflected the unification of

\footnotetext{
17 Translated from: You kena kotor ah, itu pun dia kasi bersih. Itu kaki punya sudah okay, dia punya adik jantan ah, ada jauh kerja. Dia buka restaurant ah, dia punya niaga bagui bagui mai, sebelah punya restaurant ah dia sudah hati susah, sudah buat kasi dia macam bodoh macam. Dia bukan satu orang sahaja, dia punya anak, dia semua sudah macam bodoh macam. Restaurant tak ada berniaga. Sekarang dia mari itu temple. Sekarang dia mari kelmari cakap saya punya adik satu macam ada, dia punya anak bodoh macam, tau orang sudah buat. Apa saya nak tengok itu macam jadi. Jadi Dia [the deity] cakap jangan takut. Itu, apasal itu macam jadi, orang sudah buat, dia cakap. Orang sudah buat, lu punya restaurant banyak bagui mai, sekarang dia sudah bagi buat, dalam punya restaurant. Kasi you punya anak you punya adik semua sudah satu macam jadi. Jangan takut. Saya ada, saya buat kasi lu. Dia cakap pasal Amma punya ada seorang ada mai, itu macam ada, kecik punya, dia mai semua taruh, kain sembahyang semua buat kasi. Dia cakap ini angkat pi. Pi lah Langakawi, you tau kah Langkawi, you pi you punya adik rumah you taruh. Taruh tokong ada, tokong Cina punya ada, you pi taruh, hari hari sembahyang. Sana dia boleh kasi bersih. Kasi semua bersih. Dia punya anak semua jadi bagui. Dia itu punya abang satu macam kan, sekarang semua dah jadi bagus. Sekarang restaurant sudah tinggi oh. Itu macan sudah jadi. Dia kasi Amma semua kasi bersih. Semua kasi kotor punya sudah pi. Dia punya family semua sedah okay. Restaurant ah, lagi lebih banyak orang mai. Double lah. Habis tu, ini tahun sudah buat sembahyang besar.
} 
a community. This unification seems to reflect the homogeneity of the community that suggests a specific communal significance of the temple for local Hindus.

Throughout the ten days festival, Kumar's family and even the worshippers have often urged me to join them in the rituals instead of just being a bystander and an observer. A woman who handed me a ghee lamp has urged me to pray to the deity. After the ceremony, the woman also claimed, "This Goddess is very good. Whatever you pray for will come true."18 This attempt of inclusion is by no means to suggest that they had started to perceive me as one of them - the local Hindu community, but rather, an attempt to convince me that the sakti of the Goddess is real. This shared sense of belief has accentuated the communal ties among them. The communal ties that existed between them have reflected the temple's importance, and this has helped Kumar in justifying for the temple to remain in the same area as a means of serving the religious and communal needs of not only to his family but also to the local Hindus.

In my analysis of the Deepavali Open-House event, Kumar has displayed his higher social position as the chairman of the temple through the giving out of hampers to the poor members of the local communities. He also appeared to have used a similar approach in obtaining communal support and devotion from the local Hindu worshippers through the Navratri festival. As established in the previous two case studies, the effectiveness of the management committee 's social influence had often been mentioned in the descriptions of the deity's sakti by the worshippers. The narratives of the sakti have reiterated the temple's importance as the abode and the management committee as the patron of the deity. In the case of this family temple, the family appears to have at least effectively reinforced their social position during the ten-day festival period.

Nonetheless, while the exclusivity of the family in managing this temple could be the reason for the family's difficulty in justifying the need of the temple's existence in the area, the family has appeared to have continued its social position as the temple's management committee. This exclusivity is seen as necessary in stabilising the management of the

18 Translated from: Ini tokong banyak bagui, apa-apa you minta boleh dapat. 
temple. Kumar, being the chairman, has also been the sole decision-maker in matters regarding the temple. He is not answerable to anyone regarding his decision of complying with JKR and the subsequent failure of the agreements made. On a separate occasion, I asked Kumar if any other members of the local Hindu communities had helped to share his burden on the safeguarding of the temple, he just simply said no. In fact, not only had he not asked anyone else for help, but the worshippers also seemed to be oblivious to the threat faced by the temple. Kuganeswasry said, "I know about this temple for a long time. My house is on the main road at the front [of the junction]. When the temple was there [at the previous place], we went to pray there every day. Because the land has been sold, this temple had to be out. So the people relocated the temple here. The relocation happened at night. On the next day, there was a special ceremony." 19 Kuganeswary showed no hint of discontentment on the relocation process. While the Navratri festival is intended to attract the participation of the local Hindus, it was also meant to reiterate the exclusivity of the family as the caretakers of the temple and the patrons of the deity.

\subsection{Conclusion}

In this third case study, I have suggested that the conformity and compliance approach exhibited by the management committee of the demolished and relocated Hindu temples also encompasses proactive political initiatives. In this case, I have shown that the demolition involved a family-run temple that has a lesser communal significance to the local Indian Hindus as compared to the community temples of the previous two case studies. Hence, the family has proactively courted substantial political interests that would lead to effective interventions from the DAP-led state government in the allocation of a new and ideal location for them to rebuild their family temple. As a means of obtaining substantial political interest, the family had to convince the DAP that their family temple is as important for the local community (both Indians and non-Indians) and the DAP-led state government, as it is for the family.

\footnotetext{
${ }^{19}$ Translated from: Lama, lama tau [kuil ini]. Rumah saya depan. Jalan depan. Dulu sana punya tokong, kita hari-hari pi sana. Sebab itu tanah sudah beli, Itu tokong kena keluar mai. Itu tokong sudah angkat, semua orang mari sini taruh. Itu hari dia sudah mari. Esok dia sembahyang besar, itu malam dia sudah mari.
} 
It is important to note that the proactive political initiatives taken by the family have been motivated by the fact that JKR, a federal government agency had, demolished the temple. Since the family believed that JKR would not be able to fulfil the agreement set for the demolition and relocation of their family temple, they have decided to turn to the DAP-led state government for help. The context formed from the temple demolition and relocation processes has therefore shaped the diverse ways the family engaged with the DAP-led state government as well as with the local Indian Hindu communities in safeguarding their family temple from permanent destruction.

Furthermore, it is important to note that the proactive political initiatives taken by the family have implied that the conformity and compliance approaches used had not been mainly about demonstrating powerlessness, submissiveness or meekness to the DAP-led state government. The temple chairman, Kumar, has demonstrated ways of showing conformity by encompassing a series of active political acts not only limited to complying with the bureaucratic procedures. Therefore, apart from attending meetings with the state government seeking information related to land availability and writing letters to the officials for updates, Kumar also joined the DAP as a way of showing his conformity to the hegemony of the DAP-led state government.

Kumar's compliance has evolved into his objective of establishing a clientele relationship with the DAP-led state government. Hence, he even became a member of the JKKK as a way of directly assisting the party and the state government in establishing, expanding and maintaining the local networks that could generate political support for the DAP. As the chairman of the temple and a member of the JKKK, Kumar has demonstrated that he has the leverage in attracting the DAP-led state government's political interests to help with the situation of his temple. It is worth recalling how Kumar had demonstrated his leverage to the DAP politicians through the Deepavali Open-House celebration that took place at his family's two-windowed container temple. For the event, Kumar set up a stage for the politicians to propagate their political agenda to the Indian and non-Indian communities. Then, he showed the extensiveness of his networks with the locals by not only identifying them by their names but also recognising the socio-economic backgrounds of the local 
members that came for the event. The event reflected that Kumar and his family understood the one thing that the DAP-led state government needed in sustaining their political position as the state government of Penang - the local support. Most importantly, the family was able to manipulate the needs of the DAP politicians by seeking political attention to the case of their family temple. Therefore, although Kumar's attempts in seeking help from the DAP-led state government had not been fruitful, he has, however, remained hopeful and optimistic, while simultaneously continuing with his quest in obtaining more information on the possibility of land availability, which he could then apply from the state government to rebuild his family temple.

Apart from the circumstance that JKR had demolished the temple, Kumar's proactive attitude in preserving his family temple also stemmed from the fact that the temple is being run exclusively by his family. The appearance of lack in the communal significance of his family temple to the local Hindus has suggested to the outsiders, especially the government, that the temple can be done away with without compromising the religious needs of the majority local Hindus residing in the area. Hence, Kumar and his family's initiatives indicate that their family temple indeed possesses communal significance and has simultaneously attracted participation from the local communities. To suggest the communal significance of the temple, I have demonstrated their attempts in emphasising the discovery of the temple while it was taken care of by the Chinese villagers. I have suggested that their narratives, which have been continuously highlighting the devotion of the Chinese, indicated the importance of this temple to not only the local Indian Hindu minorities but also to the local Chinese majority within the area.

Besides their attempt to include the local Chinese community in their accounts, the family has also used rituals of the Navratri festival to transform the container-temple into a central stage for religious and communal purposes. Throughout the ten-day festival, the family and worshippers joined hands and celebrated; they mingled and participated in worshipping the Goddess. It was also during this festival that I obtained the narratives of the Goddess' sakti from the worshippers. These activities demonstrated the need for the family in continuing holding the festival on a yearly basis. The congregation created a 
temporary aura that transformed the temple into a formal and proper one, even though in reality, it is still being kept inside a container. Having the crowd coming to the temple for the ten-day Navratri festival is a good opportunity for the temple to gain the much-needed publicity. The temple's popularity is therefore equated to the relevance of its existence. The relevance of the temple had also been necessary for proving to the outsiders, especially the state government and JKR, the temple's importance to the local Indian Hindus. 


\section{Conclusion}

This thesis set out to investigate the conformity and compliance approaches undertaken by the three groups of Indian Hindus in Penang as their pragmatic and strategic attempts in safeguarding their community temples from permanent destructions by the government. My argument revolves around three main themes. Firstly, I argue that their conformity and compliance have been deliberate attempts in manipulating the political interests of the Hindu temple demolition issue at a national level as a means of promoting their cases. Secondly, concerning their conformist attitude, I argue that a Hindu temple is not only religiously and communally important. It is also a source of political and social power for the management committee and politicians as well as involving communal support from the community. Thirdly, the demolition and relocation of these three temples further suggest the flexibility of the sacredness of the temples. The ways that the Indian Hindu communities made sense of the demolition and relocation of these temples suggest that the sacredness of these Hindu temples is constructed and has to be maintained by the commitment of the devotees. The rituals and ceremonies performed in the temples are important to establish and strengthen such commitments.

To examine these three themes, I have analysed three case studies of demolished Hindu temples in Penang. These three case studies displayed two important similarities in the processes of demolition and relocation of the temples. Firstly, these three temples had been situated on land that belonged to the government. Two of these three temples were on the Penang state government's land property, while the other was located at a buffer zone between a river and the main road that belonged to a federal government agency, the Department of Public Works. The respective authorities subsequently demolished these temples as part of their land redevelopment plans. Secondly, prior to the demolitions, the management committees of these three temples had made similar agreements with the relevant governments. As a way of getting the management committees' consent for the demolition, the governments had agreed to find new locations to rebuild their community temples as well as to compensate them for the 
relocation. With the arrangements made, the governments have requested the management committees of these temples to relocate the statues of the deities to temporary structures so that the existing temple buildings can be demolished to make way for development. As a result, the management committees had placed the statues of their Goddesses in temporary buildings while waiting for the government's allocation of a new site or the raising of funds in rebuilding their community temples.

Besides the similarities shown in the processes of demolition and relocation, the management committee of the three case studies also demonstrated a similar pattern of conformity towards the hegemony of the government that demolished their community temples. They even adapted to the rhetoric of the government for demolishing their community temples as making way for redevelopment plans in the area. Although they believed that placing their temples' deities in temporary buildings would compromise the deities' sakti, they still complied with the proposal of temporary relocation. However, despite their conformity and compliance, the members of the management committee across the three case studies have shown scepticism and doubts in the government's promises concerning the demolition of their community temples. When the government demolished their community temples, I have suggested that the management committees' scepticism is also their motivations for displaying submission and compliance. This is because even though they had been sceptical, their conformity and compliance gave no reason for the government not to uphold the agreement in finding a new location for their community temples.

Beneath the surface of their compliance and conformity, there was an ongoing dynamic power relation at play, which not only involved the management committee and the government. Rather, the power relations exist in a triangular form that included the government, the management committee and the members of the communities that the temples serve. The on-going and dynamic power relations between these three parties, therefore, have established the necessary frameworks for each of the three case studies. These power relations not only shaped how the management committees chose to conform and comply with the government that demolished their community temples, but it has also enabled them to devise different ways of engaging with the members of their community. Since these power relations have taken place by using the temples as major platforms, I have demonstrated how the three demolished Hindu temples had the 
potential of being a source of political and social influence for the management committee as well as for the government.

My analysis of each of the three demolished temples has revealed its political undertones. The political landscape in Penang has significantly shaped the conformity and compliance of the management committee, especially to the DAP-led state government of Penang. In Chapters Two and Three, I have reviewed the literature on the political landscape in Malaysia and Penang. In Chapter Two, I have explored Malaysia's political background that shaped the existing discourses on the issue of Hindu temple demolition by the Malay Muslim-led federal government. I also stated how earlier studies had overlooked the way Malaysian Indian Hindus had been manoeuvring their way through the hegemony of a Malay Muslim-led government. I have also claimed how existing studies that touched on the marginalisation and discrimination of Malaysian Indian Hindus had been insufficient in reflecting the political and social realities on the Hindu temples demolition issues in Malaysia. Above all, I have identified the importance of examining the voices of the Malaysian Indian Hindus as subjects to effectively understand their political and social realities.

The political context is important for the analysis of the three case studies in Penang because the communities of the three temples were well-aware of the state's political landscape under the governance of the DAP. They were aware of the constraints that the DAP-led state government would have in dealing with the issue of Hindu temples that were situated on lands that belonged to others. In particular, the compliance of the Hindu communities indicates that they were aware of the interests of the DAP in overdramatizing its political reputation as a more egalitarian political party and state government in comparison with the BN. It is worth recalling in Chapter Three, I have discussed the party's support for HINDRAF that contributed to the former's victory in the 2008 general election and had compelled DAP to manage these temples more empathetically. Therefore, Chapter Three is important in setting the context for the political intentions for the conformist attitude shown by the management committee of the three temples in Penang. The communities adapted to the existing discourses that portrayed their submissiveness as being powerless while complying with the state government's proposal in demolishing and relocating their community temples. By adjusting to the existing discourses, they have manipulated the political principles of the 
new state government of Penang in safeguarding their community temples from permanent destruction. Their approaches revealed how they were aware of the ongoing political rivalry between DAP and BN and the need for DAP to handle the issue more sensitively as compared to the BN government's that had been demolishing illegal Hindu temples in the other states, such as in Selangor. The political context is important in comprehending how the management committee believed that their compliant attitude would be effective in ensuring accountability from the DAP-led state government.

In Chapters Four, Five and Six, I have begun my analysis of the surface appearance of compliance and conformity that were exhibited by the management committees of all the three Hindu temples. Beneath their façade of compliance, I have argued that each management committee had different objectives, which often revolved around the political surroundings in Penang. In the first case study, as the management committee and the estate local Hindu community chose to wait to see what and how the state government would arrange for the new location, the Hindu community had deserted the temporary temple. I have argued that the desertion was not a demonstration of their discontentment. It was also a subtle act of delegitimizing the social position of the management committee. Their desertion has projected the importance of their participation in the temple to maintain its religious and commual significance. On the other hand, the submissiveness of the management committee in particular, demonstrated their powerlessness and subservient position as they bargained with the DAP-led state government. They were ready to demonstrate how the DAP-led state government had marginalised them if they did not receive what was being promised to them by the government. Subsequently, this would give the BN-led federal government leeway for intervention and win support from the estate community. In particular,

The sentiments of the Hindu community in the second case study appear to be opposite to those from the estate. The difference in their sentiments, such as the degree of shared anger and indignation generate different rhetoric of conformity and submissiveness between the Hindu community associated with the estate temple and the temple for the council workers. As recalled from the case in the estate, the looming sense of being betrayed and uncertainties across the estate Hindu communities showed in their responses of resentment against the management committee and the state government. 
In the second case study, however, the Hindu community had conformed to the management decision for compying with the government for demolishing their century old community temple. Their rhetoric of conformity was similar to the rhetoric that the management committee had used to show compliance with the state government's arrangement to demolish and relocate the temple. On the surface, the conformity of the management committee and the Hindu community had consistently shown their willingness and cooperation throughout the relocation process. It is noteworthy that the temple in this case study was the only temple among the three case studies, which appeared to have received effective intervention from the DAP-led state government. The government acted as a mediator between the temple committee and the developer who bought the land and as a result, had successfully negotiated with the developer in allocating a new location for the temple committee to rebuild the temple.

I have argued in the second case that the main purpose of the conformity and compliance shown by the management committee was to protect the agreement that had been made between them and the DAP-led state government. The expression of conformity shown by the management committee, in this case, has mirrored the rhetoric of the DAP-led state government's rationale for demolishing and relocating their community temple. In return, the management committee expected the DAP-led state government to compensate them for their willingness in relocating the temple. Hence, their expectations have inadvertently revealed the true intentions of their acts for compliance. However, the concerted display of conformity and compliance by the management committee and Hindu community also convey their attempts to protect the autonomy of the temple from the encroachment of the government. To recall, the management committee was willing to forego the opportunity to secure the new location as the permanent place for the temple. This is because such opportunity also wouldentail the possibility that they would have to release their autonomous control to the state government.

The third case study was a family-owned temple. The family's leader conformed to the DAP-led state government by becoming a member of the party. They even set up a stage at the temple for the DAP politicians as a means of propagating their political agenda to the local communities in the area. The family's conformity to the DAP-led state government was to seek the government's help in finding a location for them to rebuild 
their family temple that was demolished by the Department of Public Works (JKR). After JKR had demolished the temple, the family had relocated the statue Kaliamman from the temple into a container. The container had since become the temple of the family. As JKR is a federal government agency, the family had to depend on the DAP-led state government for effective intervention. Simulteneously, as the family was seeking help from the state government, they were also seeking communal participation for their family temple. They have unconventionally hosted celebrations and festivals every year to attract participation from members of the community as well as politicians.

The conformity and compliances displayed by the management committee and the Hindu community across the three case studies are complex and muliti-layered power relations between them and with the state government of Penang. There were multiple emcounters of public transcripts between the management committees, the Hindu communities and the DAP-state government. The purposes of their public transcripts are varied. For the management committee, their public transcripts suggest that they were safeguarding their social influence. For the Hindu communities, they intended to ensure that they could protect their community temples as their places for worship and abodes for the Goddesses as their protectors from permanent destruction. Even for the government, the ways that they had made promises for relocation, which were evidently difficult to keep, with the management committees, suggest that they were protecting their political reputation while intending to achieve their development agenda. The constinuous encounter of public transcripts between the three parties suggests that each party has an important role to keep these triangular yet multi layered power relations in balance. As Scott $(1990,8)$ argues, any breach in the public transcripts could carry a symbolic declaration of war. This does not necessarily mean that the management committees and the Hindu communities would be on the losing sides if such a 'war' were to accur. As shown by my analysis in the three case studies the participants were clear about what the DAP-led state government would lose if the 'war' between them does break out- the loss of electoral supports from the Indian communities, tarnishment of longstanding political reputations of egalitarianism, and possibly the position as the state government of Penang.

The different objectives by the management committees and the members of the Indian Hindu communities in safeguarding their temples have reflected the significance of a 
Hindu temple as not only limited to communal and religious aspects but also takes on a political role. Across the three case studies, the attempts made by each of the management committees have revealed how Hindu temples have often been an important source of social influence for them. This source of social influence is not determined mainly by the visibility of the size and form of these temples' structures as suggested by existing literature. Instead, the analyses of these three case studies have suggested that the communal support from members of the Hindu communities is vital for the temple to be an effective source of social influence for the management committee. Hence, across the three case studies, while the management committee had been showing conformity to the DAP-led state government, they also had to acquire conformity from the members of the community that the temple serves.

The three case studies have demonstrated different levels of communal support for the demolished temples. The Hindu estate community from the first case study objected to the demolition and relocation and subsequently refused to visit the temporary temple as a way of denying the social position of the management committee. The second case study provided an example of the importance of garnering support from the community. Their support not only sustained the effectiveness of the temple as a hierarchical institution, but they have also conformed to the management committee by adopting the similar rhetoric in explaining the required demolition and relocation of their community temple. As a result, the conformity and compliance shown by the management committee of this temple to the government appeared to be more convincing when compared to the first case study of the estate temple. As for the family temple in the third case study, their particular emphasis on the devotion of the Chinese to the Goddess in their family temple suggested that they believed in the importance of mass support from devotees in justifying the significance of their family temple. Their persistence in playing host during the annual Navratri festival and the Deepavali OpenHouse event when they could distribute food and hampers for the community suggested the ways they used in cultivating communal support from the local Hindus. As a result, this communal support has helped to elevate their social status in the community.

Therefore, the responses of the affected Hindu communities in the three case studies have indeed, suggested that they also have a part to play in maintaining the conventional discourses about Malaysian Indian Hindu minorities as powerless. It is 
also evident that the Hindu communities were less interested in changing such conventional discourses. Rather, the Hindu communities found such discourses were often useful for their subtle and indirect approaches of achieving their political objectives. Furthermore, the stark similarity of conforming and compliant attitudes of the Hindu communities across the three case studies shared, when dealing with the state government suggest their similar implicit understandings and informal networks that were cultivated over generations. Hence, the communities were confident that such performance of compliance with the government could be more effective than open protest. Moreover, it is important to emphasize that the backdrop of political context in Malaysia and the political interests in the issue of Hindu temples demolition are important factors that shaped their subtle and indirect political actions.

The dramatic changes in their community temples because of the demolition and relocation have indicated flexibility in the significance and sacredness of a Hindu temple. My findings across the three case studies consistently show that Hindu temples as sacred places are portable. The Hindu communities of these temples were willing for their community temples to be demolished and relocated. Even though the Hindu temple in the estate had objected to the recent relocation, they had agreed with the previous relocation of the temple. As my analysis shows, their discontement with the most recent relocation of the temple was mainly due to the existing frictions between the current management committee and the Hindu community. Therefore, the interpretations of the significance and sacredness of their community temples were reflected from their experiences in the demolition and relocation of their community temples. Their encounters with the demolition and relocation also reflected how they assessed their political and social surroundings about their social positions. Their experiences were then projected through their narratives on the significances of these temples that influenced their attempts at safeguarding their places of worship. Although they appeared to be conforming and complying with the government, the threats, scepticisms and insecurities that they went through had been revealed in their narratives. Their descriptions have also revealed the relationships that occurred between the management committee, members of the communities and the government. 
The accounts are given by the communities and the management committees across the three temples had many similar characteristics. Above all, these similar characteristics are mechanisms and factors that make these Hindu temples sacred places. For instance, an important mechanism to sacralise a place is to imbue the place with generational memories. As I have demonstrated, the participants across the three case studies often began by describing the significance of their community temples with how their parents and/or grandparents took them there to pray when they were young. Such oral histories have accentuated the interconnectedness between the temple, identity and attachment of the communities. Such interconnectedness also constitutes the sacredness of these Hindu temples. Furthermore, as I have discussed in Chapter Two, many peripheral Hindu temples in Malaysia are undocumented, even if they were established more than a century ago, as the Hindu communities insist. Their claims of the century old legacy could be their attempts to claim de facto ownership of the lands on which the temples were situated. As the government had requested for these three temples to be demolished, the claim of their community temples to be a century old could also be their attempt to piggyback on the political reputation of the DAP as empathatic to the religious freedom of the minorities to negotiate for rebuilding these temples elsewhere.

Besides, these three Hindu temples are also imbued with mythical beliefs. Another distinct emphasis that the participants across the three case studies shared was how they described the Goddesses in their community temples as living beings. Their claims of the Goddesses as living beings amplified two major aspects of their community temples. Firstly, they highlighted the temple's important function as an abode for the Goddesses. As an abode for the Goddesses, the management committee would be able to make sense of the demolition and relocation of their community temples if they had obtained a mandate or approval from the Goddesses. Secondly, as the communities believed that the Goddesses are living beings, they believed that their arcannai relationships with the Goddesses would be more effective. The arcannai relationships not only reinforced the communities' devotion to the Goddesses, but they would also be more willing to identify the temples as their community temples. Such arcannai relationships have suggested how a Hindu temple, regardless of its shape and size, can be important for a community who believes in the sakti of the Goddess that is housed in 
the temple. Such arcannai relationships strengthen the commitment within the local Hindu community, which is another important mechanism to sacralise these temples as sacred places.

Furthermore, due to the communal significance of these temples, they have also become the institutions that establish the hierarchical social relations between the management committee and the local Hindu community. For the management committees, the arcannai relationships between the community and the Goddesses are important for the temples to function effectively as community temples. This is because the arcannai relationships also signify how the communities identify the Goddesses as having sakti, which is also an indirect acknowledgement of the management committee as the patron of the Goddesses. Therefore, across the three case studies, the efforts of the management committees were particularly prominent. Their attempts through their narratives about the sakti of the Goddesses, their organisations of celebrations, special ceremonies and festivals have projected their underlying objective to maintain the participations of the local Hindu communities.

Nevertheless, the arcannai relationships between the Goddesses and the communities do not necessarily equate to the acceptance of the management committee's social position in a communal hierarchy. As demonstrated by the community in the estate, they decided not to worship the deity that had been relocated to the temporary structure after the demolition of their community temple. From their responses, it was clear that their refusal had not meant that they had decided not to believe in the sakti of the deity. On the contrary, their narratives have indicated that the sakti of the Goddess imposes punitive actions and that those who were responsible for the demolition would suffer the consequences. They were clear in their desertion of the temporary temple as being unrelated to their devotion to the Goddess. However, as I have presented in the case study, because of their desertion of the temple, the temple has often been left empty and unkempt. It is worth recalling, the priest has claimed he has not heard the sounds of the Goddess at night as he used to before the demolition and relocation of the temple.

The second and third case studies also provided examples of segregation between the devotion of the community and their conformity to the management committee. In the 
second case study, for instance, the management committee hosted a series of rituals for the relocation of the Goddess as a means of demonstrating how they had received a mandate from the Goddess to be relocated. From the responses shown by the community, they appeared to be convinced as they had witnessed good omens during the rituals, which signified that the Goddess had granted permission. Hence, the way the management committee saw a need in convincing the community suggested that they were aware of the importance of acquiring the Goddess' consent. In the third case study, the approaches of the family in organising the Navratri Festival and the Deepavali OpenHouse event have demonstrated the implementation of different ways in trying to obtain mass communal support from the local Hindus. Kumar often claimed he was acting on the Goddess' behalf in hosting festivals and events, and feeding the guests and worshippers, reflected the methods he used in promoting the Goddess of the temple to the local Hindus. Even though the statue of the Goddess was still being kept in a container, Kumar and his family persisted in organising the festival as a means of establishing and retaining relationships between the Goddess and the local Hindus.

This thesis serves as an important contribution to the analysis of Indian Hindus as the subjects in the issue of demolition and relocation of Hindu temples in Malaysia. With their community temples being constantly faced with threats of demolition, the Indian Hindus' pragmatic responses suggest that they are capable of finding ways to manoeuvre their ways through the hegemony of the government. Their pragmatic responses suggest that they can engage actively with their political and social surroundings despite being the minorities. Their active engagements imply that within the ambit of their political and social realities they were aware of their useful political positions as minorities for both the opposition and mainstream political parties in Malaysia. Above all, their involvement suggests that they are capable of manipulating their political relations with the Malay Muslim-led government as well as the social relations with the Chinese communities as ways of benefiting their cases. Hence, with this thesis, I suggest the importance of returning the narrator positions to the Indian Hindus who have been affected by the issue. This is because their experiences often project their political and social realities more effectively as the discriminated and marginalised minority in a Malay Muslim-led country. 


\section{Appendix}

\section{Interview questions}

The managing committee of the temple (including the chairpersons and the members of the temple)

1. Can you please tell me about the demolition?

2. What are your strategies to handle the issue?

3. What are your challenges to handle the issue?

4. Can you please describe the background of this temple?

5. Who is currently managing the temple?

6. What are the rituals and ceremonies performed in this temple?

7. What does the temple mean for you and your community?

\section{The Devotees}

1. Demographic background

- Name, sex, age, occupation, place of residence, ethnic/caste.

2. What does the temple mean to you and your family?

3. What do you know about the demolition/about the temple receiving notice of demolition?

4. What is your opinion about the issue?

5. What do you think the committee should do and why?

6. How do you think the demolition of the temple will affect the community?

\section{External parties involved with the temple demolition}

1. Introduction

a. Name, age, ethnic, religion, place of residence, occupation

b. Position, in this case, duration of handling this case

2. What is your opinion about the temple?

3. What are the processes to decide for the temple to be demolished?

4. What are your proposals for the community affected? 


\section{Observation:}

1. The condition of the temple. (Size, the material used for the building, the number of deities)

2. Location of the temple. (by river/road/railway, the condition of the land, density and the building nearby)

3. Who was present during the interview?

4. Approximately how many people coming to the temple

a. Sex, age, ethnic

b. At what period?

5. What rituals, ceremonies and festivals hosted by the temple? (Anniversary, wedding, ear piercing etc.)

a. Around how many people participated?

b. Sex, age, ethnic

c. What kind of the ceremonies? Describe

i. Date, time, venue

ii. What special rituals (animal sacrifice, fire walking etc.)

6. Who presents at the meeting?

a. When did the meetings usually held?

b. Where did the meeting usually held

c. Who presents at the meetings?

i. How many people turn up?

ii. Who are they? (Committee? Devotees? Media? Politicians? Attorney?)

1. Age, sex, ethnic

iii. What is the agenda?

1. Who participated in the discussion?

2. What are the general situations of the meeting 


\section{References}

Adil, Mohamed Azam Mohamed, and Mohd Afandi Mat Rani. 2014. "The Implementation of Land Acquisition Act 1960 and Its Negative Impact on the Development of Waqf (Endowment) Land in Malaysia." Islam and Civilisational Renewal (ICR) 5 (3).

Ahmad, Ani, and Abu Daud Silong. 2011. Issues and Challenges Affecting Village Leadership Effectiveness for Rural Community Development in Malaysia. Selangor: Universiti Putra Malaysia.

Ampalavanar, Rajeswary. 1981. The Indian Minority and Political Change in Malaya, 1945-1957. Kuala Lumpur: Oxford University Press.

Anbalakan, K. 2003. "The New Economic Policy and Further Marginalisation of Indians " Kajian Malaysia 21 (1\&2):379-98.

Appadurai, Arjun. 1981. Worship and Conflict under Colonial Rule: A South Indian Case. Vol. 27. Cambridge: Cambridge University Press

Appadurai, Arjun, and Carol Appadurai Breckenridge. 1976. "The South Indian Temple: Authority, Honour and Redistribution." Contributions to Indian Sociology 10 (2):187-211. doi: 10.1177/006996677601000201.

APT Youtube Channel. 2013. Keluhan Penduduk Byram Terhadap Kerajaan Negeri Dapig. YouTube.

Arasaratnam, Sinnappah. 1979. Indians in Malaysia and Singapore. Selangor: Oxford University Press.

---. 1993. "Malaysian Indians: The Formation of Incipient Society." In Indian Communities in Southeast Asia (First Reprint 2006), edited by Kernial Singh Sandhu and A. Mani, 190-211. Singapore: institute of Southeast Asian Studies. Ariffin, Lisa J. 18 April 2013. "Waytha Gives Full Backing to Najib, Bn." FMT News, Nation. Accessed 28 June 2016. http://www.freemalaysiatoday.com/category/nation/2013/04/18/waythagives-full-backing-for-najib-bn/. 
Atran, Scott, and Robert Axelrod. 2008. "Reframing Sacred Values." Negotiation Journal 24 (3):221-46. doi: 10.1111/j.1571-9979.2008.00182.x.

Atran, Scott, and Jeremy Ginges. 2012. "Religious and Sacred Imperatives in Human Conflict." Science 336 (6083):855-7.

Aveling, Marian. 1978. "Ritual Change in the Hindu Temples of Penang." Contribution to Indian Sociology Delhi 12 (2):173-94.

Barraclough, Simon. 1983. "Managing the Challenges of Islamic Revival in Malaysia: A Regime Perspective." Asian Survey 23 (8):958-75. doi: 10.2307/2644266.

Baumann, Martin. 2001. "The Hindu Diaspora in Europe and an Analysis of Key Diasporic Patterns." In Hindu Diaspora: Global Perspectives, edited by T. S. Rukmani, 59-80. New Delhi: Munshiram Manoharlal.

---. 2009. "Templeisation: Continuity and Change of Hindu Traditions in Diaspora." Journal of Religion in Europe 2 (2):149-79.

Bayat, Asef. 2013. Life as Politics: How Ordinary People Change the Middle East. Amsterdam: Amsterdam University Press.

Bayat, Asef 1997. "Cairo's Poor: Dilemmas of Survival and Solidarity." Middle East Report 202:7.

Beckerlegge, Gwilym. 2001. "Hindu Sacred Images for the Mass Market." In Religion Today: From Sacred Text to Internet, edited by Gwilym Beckerlegge, 57-116. Milton Keynes: The Open University.

Belle, Carl Vadivella. 2008a. "Indian Hindu Resurgence in Malaysia." K. Kesavapany, A. Mani, \& P. Ramasamy, Rising India and Indian communities in East Asia:456-80. ---. 2008b. "Forgotten Malaysians? Indians and Malaysian Society." Tracing an Indian Diaspora: Contexts, Memories, Representations:52.

---. 2015. Tragic Orphans: Indians in Malaysia. Vol. 496. Singapore: Institute of Southeast Asian Studies.

BERNAMA. 25 February 2018. "No More Temples Will Be Demolished If Bn Wins Selangor, Says Pm’s Aide." Free Malaysia Today. http://www.freemalaysiatoday.com/category/nation/2018/02/25/no-moretemples-will-be-demolished-if-bn-wins-selangor-says-pms-aide/.

Bhana, Surendra. 1999. "Natal's Traditional Temples in the 19th and Early 20th Centuries'." In Hindu Diaspora: Global Perspectives, edited by T. S. Rukmani, 289306. Montreal: Concordia University. 
Brockington, Dan, and Sian Sullivan. 2003. "Qualitative Research." In Development Fieldwork: A Practical Guide, edited by Regina Scheyvens and Donovan Storey, 57-74. London, Thousand Oaks, New Delhi: Sage Publications.

Bunnell, Tim, Sabitha Nagarajan, and Andrew Willford. 2010. "From the Margins to Centre Stage:'Indian’ Demonstration Effects in Malaysia's Political Landscape." Urban Studies 47 (6):1257-78.

Chanderbali, David. 2008. Indian Indenture in the Straits Settlements, 1872-1910: Peepal Tree.

Cheah, Chor Sooi. 2008. "Restoring Penang's Pride as a Dynamic State." Malaysian Business:3.

Chin, James. 2013. "So Close and yet So Far: Strategies in the 13th Malaysian Elections." The Round Table 102 (6):533-40. doi: 10.1080/00358533.2013.857145.

Clothey, Fred W. 2006. Ritualizing on the Boundaries: Continuity and Innovation in the Tamil Diaspora. Columbia: University of South Carolina Press.

Dahlan, Nur Khalidah, Noor Inayah Yaa'kub, Mohamad Abdul Hamid, and Mohd Rizal Palil. 2014. "Waqf (Endowment) Practice in Malaysian Society." International Journal of Islamic Thought 5:56-61.

Dasgupta, Anindita. 2013. "Malaysian-Indians: Rough Road to Equality?" Economic and Political Weekly 48 (19).

David, Ann R. 2012. "Sacralising the City: Sound, Space and Performance in Hindu Ritual Practices in London." Culture and Religion 13 (4):449-67. doi: 10.1080/14755610.2012.728141.

Democratic Action Party. 1969. Who Lives If Malaysia Dies: The Dap's Case for a MultiRacial Society. Kuala Lumpur: Democratic Action Party.

Department of Statistic Malaysia. 2010. Population Distribution and Basic Demographic Characteristics. Kuala Lumpur: Population and Housing Census of Malaysia.

Drabble, John H. 2000. An Economic History of Malaysia, C. 1800-1990: The Transition to Modern Economic Growth. London: Macmillan Basingstoke.

Ezzy, Douglas. 2002. Qualitative Analysis: Practice and Innovation. Crows Nest: Allen \& Unwin.

Federal Department of Town and Country Planning Peninsular Malaysia. 2002. Mosque Planning Guidelines (Garis Panduan Perancangan Tempat Ibadat Islam). Kuala Lumpur: Ministry of Housing and Local Government Malaysia. 
Fernandez, Dorothy Z., Amos H. Hawley, and Silvia Predaza. 1975. 1974 World Population Year: The Population of Malaysia. Edited by J. M. N. R. Chander. Malaysia: International Co-ordination on National Research in Demography (CICRED) Series.

FMT News. 2015. "Penang Hindu Endowment Board to Be Referred to Ag." Free Malaysia Today, December 11 Nation.

http://www.freemalaysiatoday.com/category/nation/2015/12/11/penanghindu-endowment-board-to-be-referred-to-ag/.

Friedland, Roger, and Richard D Hecht. 1991. "The Politics of Sacred Place: Jerusalem's Temple Mount/Al-Haram Al-Sharif." In Sacred Places and Profane Spaces: Essays in the Geographics of Judaism, Christianity, and Islam, edited by Jamie Scott and Paul Simpson-Housley, 21-61. Westport: Greenwood Press.

Gill, Savinder Kaur, and Nirmala Devi Gopal. 2010. "Understanding Indian Religious Practice in Malaysia." Journal of Social Sciences 25 (1-2-3):135-46.

Goh, Ban Lee. 2009. "Social Justice and the Penang Housing Question." Penang outlook Forum.

Gopal, Parthiban S., and Premalatha Karupiah. 2013. "Indian Diaspora and Urban Poverty: A Malaysian Perspective." Diaspora Studies 6 (2):103-22.

Greenhouse, Carol J. 2005. "Hegemony and Hidden Transcripts: The Discursive Arts of Neoliberal Legitimation." American Anthropologist 107 (3):356-68.

Hamid, Jalil. 8 November 2007. "Malaysia Ethnic Indians in Uphill Fight on Religion." Reuters, Top News. https://in.reuters.com/article/idINIndia30397720071108?pageNumber=1.

Hardy, Adam. 1995. Indian Temple Architecture: Form and Transformation: The Karnāta Drāviḍa Tradition, 7th to 13th Centuries. New Delhi: Abhinav Publications.

HINDRAF. 7 August 2007. "About Hindraf." HINDRAF Accessed 18 July 2016. http://www.hindraf.co/index.php/component/content/article/9uncategorised/68-about-hindraf.

Hisham, S, Hazel Adria Jasiran, and Kamaruzaman Jusoff. 2013. "Substitution of Waqf Properties (Istibdal) in Malaysia: Statutory Provisions and Implementations." Middle-East Journal of Scientific Research 13 (13):23-7. 
Holmes, Peter. 1982. Resistance and Compromise: The Political Thought of the Elizabethan Catholics. Cambridge, New York and Melbourne: Cambridge University Press.

Hutter, Manfred. 2004. "Being Hindu in Malaysia: On Par with Other Religions or a Cause of Disharmony?" Religious Harmony: Problems, Practice, and Education., Yogyakarta and Semarang, Indonesia.

Isa, Zuraidah Mohamed, Norhidayah Ali, and Rabitah Harun. 2011. "A Comparative Study of Waqf Management in Malaysia." International Conference on Sociality and Economics Development, Singapore.

Jain, Ravindra K. 1984. "South Indian Labour in Malaya, 1840-1920: Asylum, Stability and Involution." In Indentured Labour in British Empire 1834-1920, edited by Kay Saunders, 158-82. London and Canberra: Croom Helm.

Jain, Ravindra K. 1993. "Tamilian Labour and Malayan Plantations, 1840-1938." Economic and Political Weekly 28 (43):2363-70.

Jha, Pankaj Kumar. 2009. "Religious Assertion in Malaysia: Constrained or Conflagrated?" Strategic Analysis 33 (6):890-902. doi: 10.1080/09700160903255897.

Jomo, Kwame Sundaran. 1990. "Whither Malaysia's New Economic Policy?" Pacific Affairs 63 (4):469-99. doi: 10.2307/2759912.

Kaur, Amarjit. 2012. "Labour Brokers in Migration: Understanding Historical and Contemporary Transnational Migration Regimes in Malaya/Malaysia." International Review of Social History 57 (S20):225-52. doi: http://dx.doi.org/10.1017/S0020859012000478.

Kent, Alexandra. 2005. Divinity and Diversity: A Hindu Revitalization Movement in Malaysia. Vol. 98. Copenhagen: Nias Press.

Khoo, Boo Teik. 2010. Cyber-Networks, Physical Coalitions and Missing Links: Imagining and Realizing Dissent in Malaysia 1998-2008. Institute of Developing Economies.

Khoo, Kay Kim. 2009. "The Emergence of Plural Communities in the Malay Peninsula before 1874." In Multiethnic Malaysia: Past, Present, and Future, edited by Teck Ghee Lim, Alberto Gomes and Rahman Azly, 14-6. Petaling Jaya: Strategic Information and Research Development Centre (SIRD). 
Kinnard, Jacob N. 2014. Places in Motion: The Fluid Identities of Temples, Images, and Pilgrims. New York: Oxford University Press.

Knott, Kim. 1987. "Hindu Temple Rituals in Britain: The Reinterpretation of Tradition." In Hinduism in Great Britain: The Perpetuation of Religion in an Alien Cultural Milieu, edited by Richard Burghart, 157-79. London: Tavistock Publications.

Kong, Lily. 1993. "Negotiating Conceptions of 'Sacred Space': A Case Study of Religious Buildings in Singapore." Transactions of the Institute of British Geographers 18 (3):342-58. doi: 10.2307/622464.

Kramrisch, S., and R. Burnier. 1996. "The Site: Tirtha and Temple." In The Hindu Temple, 3-4. Delhi: Motilal Banarsidass.

Kumar, P. Pratap. 2013. Hinduism and the Diaspora: A South African Narrative. Jaipur: Rawat Publications.

Lai, Fong Yang, and Md Sidin Ahmad Ishak. 2012. "Framing Interethnic Conflict in Malaysia: A Comparative Analysis of Newspaper Coverage on the Hindu Rights Action Force (Hindraf)." International Journal of Communication (19328036) 6:166-89.

Lal, Vinay. 2006. "Multiculturalism at Risk: The Indian Minority in Malaysia." Economic and Political Weekly, 3764.

Lee, Edmund. 22 September 2015. "Penang Establishes Fund for Non-Islamic Places of Worship." The Sun Daily, News. http://www.thesundaily.my/news/1560481. Lee, Hock Guan. 2008. "Malaysia in 2007: Abdullah Administration under Siege." Southeast Asian Affairs 2008 (2008):187-206.

Lee, Kam Hing. 2009. "Forging Interethnic Cooperation: The Political and Constitutional Process toward Independence, 1951-1957." In Multiethnic Malaysia: Past, Present and Future, edited by Teck Ghee Lim, Alberto Gomes and Rahman Azly, 59-76. Petaling Jaya: SIRD.

Lee, Raymond L. M. 1986a. "The Ethnic Implications of Contemporary Religious Movements and Organizations in Malaysia." Contemporary Southeast Asia 8 (1):70-87. doi: 10.2307/25797883.

---. 1988. "Patterns of Religious Tension in Malaysia." Asian Survey 28 (4):400-18. doi: $10.2307 / 2644735$.

Lee, Raymond LM. 1986b. "Symbols of Separatism: Ethnicity and Status Politics in Contemporary Malaysia." Ethnicity and ethnic relations in Malaysia:28-46. 
---. 1986c. "Symbols of Separatism: Ethnicity and Status Politics in Contemporary Malaysia." In Ethnicity and Ethnic Relations in Malaysia, edited by Raymond LM Lee, 28-46. Northen Illinois: Northen Illinois University.

Lee, Raymond LM, and R Rajoo. 1987. "Sanskritization and Indian Ethnicity in Malaysia." Modern Asian Studies 21 (02):389-415.

Lee, Raymond LM, and Susan E. Ackerman. 1997. Sacred Tensions: Modernity and Religious Transformation in Malaysia. South Carolina: University of South Carolina Press.

Leong, Susan. 2009. "The Hindraf Saga: Media and Citizenship in Malaysia." ANZCA09 Communication, Creativity and Global Citizenship, Brisbane.

Lian, Kwen Fee, and Jayanath Appudurai. 2011. "Race, Class and Politics in Peninsular Malaysia: The General Election of 2008." Asian Studies Review 35 (1):63-82. doi: 10.1080/10357823.2011.552706.

Lian, Kwen Fee 2002. "The Political and Economic Marginalisation of Tamils in Malaysia." Asian Studies Review 26 (3):309-29. doi: $10.1080 / 10357820208713348$.

Lim, Ida, and Clara Chooi. 1 September 2013. "Mic, Pkr Leaders Arrested in Standoff over Alleged Demolition of Century-Old Temple." MalayMail Online, Malaysia. http://www.themalaymailonline.com/malaysia/article/four-arrested-instandoff-over-temple-demolition.

Loh, Francis Kok Wah. 2003. "The Marginalisation of the Indians in Malaysia: Contesting Explanations and the Search for Alternatives." In Southeast Asia over Three Generations: Essays Presented to Benedict R. O'g. Anderson, edited by B.R.O.G. Anderson, James.T. Siegel and A. Kahin, 223-44. New York: Southeast Asia Program Publications, Southeast Asia Program, Cornell University.

---. 2010. "Restructuring Federal-State Relations in Malaysia: From Centralised to CoOperative Federalism?" The Round Table 99 (407):131-40. doi: 10.1080/00358531003656180.

MacDonald, Stuart. 2011a. Supply and Demand in the Penang Housing Market: Assessing Affordability. Penang: Penang Institute.

---. 2011b. Drivers of House Price Inflation in Penang, Malaysia: Planning a More Sustainable Future. Penang: Penang Institute. 
Mahmood, Saba. 2001. "Feminist Theory, Embodiment, and the Docile Agent: Some Reflections on the Egyptian Islamic Revival." Journal of Cultural anthropology 16 (2):202-36.

Malaysiakini. 12 January 2018. "Johor Mb Calls for Calm after Hindu Temple

Demolition." Malaysiakini, News. https://www.malaysiakini.com/news/408497. MalaysianDigest. 11 November 2013. "Putrajaya Defends Temple Demolition, Says Consulted Hindu Priest." Malaysian Digest, Top Stories.

http://www.malaysiandigest.com/news/479014-putrajaya-defends-templedemolition-says-consulted-hindu-priest.html\#startOfPage.

Manickam, Janakey Raman. 2009. The Malaysian Indian Dilemma: The Struggles and Agony of the Indian Community in Malaysia. Kalng: Nationwide Human Development and Research Centre.

Maznah, Mohamad. 2010. "Making Majority, Undoing Family: Law, Religion and the Islamization of the State in Malaysia." Economy and Society 39 (3):360-84. doi: 10.1080/03085147.2010.486218.

Mazumdar, Shampa, and Sanjoy Mazumdar. 1993. "Sacred Space and Place Attachment." Journal of Environmental Psychology 13 (3):231-42. doi: http://dx.doi.org/10.1016/S0272-4944(05)80175-6.

Means, Gordon P. 1972. "'Special Rights' as a Strategy for Development: The Case of Malaysia." Comparative Politics 5 (1):29-61. doi: 10.2307/421353.

Mearns, David. 1987. "Caste Overseas: Does It Matter? Urban Indians in Malaysia." Contributions to Indian Sociology 21 (2):285-306. doi: $10.1177 / 006996687021002002$.

Michaels, Axel. 2015. Homo Ritualis: Hindu Ritual and Its Significance for Ritual Theory. New York: Oxford University Press.

Michell, George. 1977. The Hindu Temple: An Introduction to Its Meaning and Forms. Chicago and London: University of Chicago Press.

Mines, Diane P. 2005. Fierce Gods: Inequality, Ritual, and the Politics of Dignity in a South Indian Village. Bloomington: Indiana University Press.

Mines, Mattison. 1994. Public Faces, Private Lives: Community and Individuality in South India. London: University of California Press.

Mohammedan and Hindu Endowments. 1905. Mohammedan and Hindu Endowments Ordinance No. 92. In 92. London: Waterlow and Sons Limited. 
Mok, Opalyn. 20 June 2017. "Penang Raises Budget for Temples, Churches." Malay Mail Online, June 20, 2017, Malaysia.

http://www.themalaymailonline.com/malaysia/article/penang-raises-budgetfor-temples-churches\#58V8p0x1dGsYqyh1.97.

Mokhtar, Tunku Mohar. 2008. "The Twelfth General Elections in Malaysia." Intellectual Discourse 16 (1).

Mol, Hans. 1976. Identity and the Sacred: A Sketch for a New Social-Scientific Theory of Religion: Blackwell Oxford.

Morrison, Ian. 1949. "Aspects of the Racial Problem in Malaya." Pacific Affairs 22 (3):239-53. doi: 10.2307/2751796.

Mubayi, Yaaminey. 2005. Altar of Power: The Temple and the State in the Land of Jagannatha Sixteenth to Nineteenth Centuries. Vol. 4: Manohar Publishers.

Mukund, Kanakalatha. 2005. The View from Below: Indigenous Society, Temples, and the Early Colonial State in Tamilnadu, 1700-1835: Orient Blackswan.

Munusamy, Vijayan P. 2012. "Ethnic Relations in Malaysia: The Need for "Constant Repair" in the Spirit of Muhibbah." In Handbook of Ethnic Conflict, 119-36. Springer.

Muzaffar, Chandra. 1993. "Political Marginalization in Malaysia." In Indian Communities in Southeast Asia, edited by Kernial Singh Sandhu and A. Mani, 211-36.

Singapore: Institute of Southeast Asian Studies.

Nagata, Judith. 1980. "Religious Ideology and Social Change: The Islamic Revival in Malaysia." Pacific Affairs 53 (3):405-39. doi: 10.2307/2757302.

Nagata, Judith A. 1979. Malaysian Mosaic: Perspectives from a Poly-Ethnic Society: University of British Columbia Press Vancouver.

Nasution, Khoo Salma. 2002. "Colonial Intervention and Transformation of Muslim Waqf Settlements in Urban Penang: The Role of the Endowments Board." Journal of Muslim Minority Affairs 22 (2):299-315. doi: 10.1080/1360200022000028112.

Netto, George. 1961. Indians in Malaya: Historical Facts and Figures. Singapore The Author.

Ngui, Aaron. 2015. "Penang Hindu Endowments Board Denies Land Grab Accusations." The Sun Daily, December 14 
Noor, Farish Ahmad. 2008. The Hindu Rights Action Force (Hindraf) of Malaysia: Communitarianism across Borders? Singapore: S. Rajaratnam School of International Studies, Nanyang Technological University.

Noordin, Zalinah, and Winnie Yeoh. 11 December 2011. "Dap's Karpal Singh Lashes out at Ramasamy." The Star Online, Nation. http://www.thestar.com.my/news/nation/2011/12/11/daps-karpal-singhlashes-out-at-ramasamy/.

Patton, Michael Quinn. 1999. "Enhancing the Quality and Credibility of Qualitative Analysis." Health Services Research 34 (5 Pt 2):1189-208.

Penang Economic Monthly. 2009. "Social Justice and the Penang Housing Question." Penang Economic Monthly.

Pillai, Shanthini. 2007. Colonial Visions, Postcolonial Revisions: Images of the Indian Diaspora in Malaysia. Newcastle: Cambridge Scholars Publication.

Pintchman, Tracy. 2015. "Introduction." In Sacred Matters: Material Religion in South Asian Traditions, edited by Tracy Pintchman and Corinne G Dempsey, 1-14. Albany: SUNY Press.

Polak, H. S. L. 1941. "Indian Emigration Overseas." Journal of the Royal Society of Arts 89 (4578):85-101.

Prorok, Carolyn. 1998. "Dancing in the Fire: Ritually Constructing Hindu Identity in a Malaysian Landscape." Journal of Cultural Geography 17 (2):89-114. doi: $10.1080 / 08873639809478322$.

Prorok, Carolyn V. 2015. "The Materiality of Diasporic Identity: Hindu Temples in Trinidad and Malaysia." In Indian Diaspora: Socio-Cultural and Religious Worlds, edited by P. Pratap Kumar, 252-79. Leiden and Boston: Brill.

Prufer, Keith M. 2015. "Introduction

Sacred Spaces as Subject and Study in the Mesoamerican Landscape." In Memory Traces, 3-20. University Press of Colorado.

R. Sekaran. 2018. "Legal Tussle over Management of 105-Year-Old Temple." The Star Online, January 11, Nation.

https://www.thestar.com.my/news/nation/2018/01/11/legal-tussle-overmanagement-of-105yearold-temple/\#LzkvCDpE6o4PGI5X.99. 
Ramanathan, Kalimuthu. 1995. "Hindu Religion in an Islamic State: The Case of

Malaysia." Doctorate degree, Instituut voor Moderne Aziatische Geschiedenis, Universiteit van Amsterdam.

Ramasamy, Palanisamy. 1992. "Labour Control and Labour Resistance in the Plantations of Colonial Malaya." The Journal of Peasant Studies 19 (3-4):87-105.

Ramasamy, Rajakrishnan. 1984. Caste Consciousness among Indian Tamils in Malaysia. Petaling Jaya: Pelanduk publications.

Sandhu, Kernial Singh. 1969. Indians in Malaya: Some Aspects of Their Immigration and Settlement (1786-1957). Reprint, Reissue ed. Cambridge: Cambridge University Press.

---. 2010. Indians in Malaya: Some Aspects of Their Immigration and Settlement (17861957). Reprint, Reissue ed. London: Cambridge University Press.

Scheyvens, Regina, Henry Scheyvens, and Warwick E. Murray. 2003. "Working with Marginalised, Vulnerable or Privileged Groups." In Development Fieldwork: A Practical Guide, edited by Regina Scheyvens and Donovan Storey, 167-94. London, Thousand Oaks, New Delhi: Sage Publication.

Scott, James C. 1990. Domination and the Arts of Resistance: Hidden Transcripts. New Haven and London: Yale University Press.

---. 2008. Weapons of the Weak: Everyday Forms of Peasant Resistance. New Haven and London: Yale university Press.

Seow, Victor. 21 October 2015. "Funding for Non-Muslim Places of Worship." Buletin Mutiara, News/Reports. http://www.buletinmutiara.com/funding-for-nonmuslim-places-of-worship/.

Shagar, Loshana K. 8 February 2014. "Hindraf: Waytha Moorthy to Quit as Deputy Minister." The Star Online, Nation.

http://www.thestar.com.my/news/nation/2014/02/08/hindrafwahthamoorthy-resigns/.

Shankar, Athi. 31 October 2013. "Hindraf Jibes Guan Eng with Hampers." Free Malaysia Today, Nation.

http://www.freemalaysiatoday.com/category/nation/2013/10/31/hindrafjibes-guan-eng-with-hampers/.

Sheikh, Hammad, Jeremy Ginges, Alin Coman, and Scott Atran. 2012. "Religion, Group Threat and Sacred Values." Judgment and Decision Making 7 (2):110. 
Shukla-Bhatt, Neelima. 2015. "Celebrating Materiality: Garbo, a Festival Image of the Goddess in Gujarat." In Sacred Matters: Material Religion in South Asian

Traditions, edited by Tracy Pintchman and Corinne G. Dempsey, 89-114. Albany: State University of New York Press.

Simmons, Caleb, and Moumita Sen. 2018. "Introduction: Movements of Navaratri." In Nine Nights of the Goddess: The Navaratri Festival in South Asia edited by Caleb Simmons, Moumita Sen and Hilary Rodrigues, 1-23. Albany, NY: State University of New York.

Singh, Hari. 2001. "Ethnic Conflict in Malaysia Revisited." Commonwealth and Comparative Politics 39 (1):42-65.

Sinha, Vineeta. 2005. A New God in the Diaspora?: Muneeswaran Worship in Contemporary Singapore. Singapore: Singapore University Press.

---. 2011. "The Mohammedan and Hindu Endowments Ordinance, 1905: Recourse to Legislation." In Religion-State Encounters in Hindu Domains, 83-124. Springer Netherlands.

Sipalan, Joseph. 24 April 2014. "Putrajaya Moots Law to Manage Non-Muslim Houses of Worship." Malay Mail Online, 24 April 2014, Malaysia.

http://www.themalaymailonline.com/malaysia/article/putrajaya-moots-law-tomanage-non-muslim-houses-of-worship.

Smith, Jonathan Z. 1992. To Take Place: Toward Theory in Ritual. Chicago and London: University of Chicago Press.

Sosis, Richard. 2004. "The Adaptive Value of Religious Ritual: Rituals Promote Group Cohesion by Requiring Members to Engage in Behaviour That Is Too Costly to Fake." American Scientist 92 (2):166-72.

Sosis, Richard, and Candace Alcorta. 2003. "Signalling, Solidarity, and the Sacred: The Evolution of Religious Behaviour." Evolutionary Anthropology: Issues, News, and Reviews 12 (6):264-74.

Stark, Jan. 2006. "Indian Muslims in Malaysia: Images of Shifting Identities in the MultiEthnic State." Journal of Muslim Minority Affairs 26 (3):383-98. doi: $10.1080 / 13602000601141398$.

Steele, Janet. 2013. "Malaysiakini's Citizen Journalists: Navigating Local and National Identities Online." In Democracy, Media and Law in Malaysia and Singapore: A 
Space for Speech, edited by Andrew T Kenyon, Tim Marjoribanks and Amanda Whiting, 60-82. London and New York: Routledge.

Stenson, Michael. 1980. Class, Race and Colonialism in West Malaysia: The Indian Case. Vancouver: University of British Columbia.

Subhasree, M. 2014. "Folk Songs of Tamil Nadu with Special Reference to Kummi." JOURNAL OF DEVELOPMENT MANAGEMENT AND COMMUNICATION 1 (1):49.

Supernor, Dennis Earl. 1983. "Tamils in Malaysia: Problems in Socio-Economic Development for an Immigrant Minority Group." Doctor of Philosophy Microfilm, Anthropology, Rice University.

Tan, Royce. 23 September 2015. "Religious Trust Fund Formed for the Upkeep of NonIslamic Places of Worship." The Star Online, Community. http://www.thestar.com.my/metro/community/2015/09/23/religious-trustfund-formed-rm56mil-pooled-for-upkeep-of-nonislamic-places-of-worship/.

Teo, Sue Ann. 2014. "Home Runs for the Home Boys." In Electoral Dynamics in Malaysia: Findings from the Grassroots, edited by Meredith Leigh Weiss, 65-81. Petaling Jaya and Pasir Panjang: Strategic Information and Research Development Centre, Malaysia.

The Financial Express. 23 May 2006. "Hindu Group Protests 'Temple Cleansing' in Malaysia." Indian Express Newspapers, Religion. https://web.archive.org/web/20070704022731/http://www.financialexpress.c om/latest full story.php?content id=128069.

The Star Online. 16 July 2016. "Build School before Taking Land, Pdc Told." The Star Online, Nation. http://www.thestar.com.my/news/nation/2016/07/16/buildschool-before-taking-land-pdc-told/.

---. 22 March 2012. "Board Members Fire Back at Dap National Chairman." The Star Online, Nation.

---. 26 June 2012. "Another Round of Karpal Vs Ramasamy Feud?" The Star Online, Nation. http://www.thestar.com.my/news/nation/2012/06/26/another-roundof-karpal-vs-ramasamy-feud/.

---. 30 November 2013. "Temples to Make Way for Project." The Star Online, 30 November 2013, Community.

http://www.thestar.com.my/news/community/2013/11/30/temples-to-makeway-for-project-committee-members-agree-with-relocation-plan/. 
---. 2016. "Group Wants Back Temple but Endowment Board Says No." The Star Online, August 29 Accessed 06 October 2018.

https://www.thestar.com.my/metro/community/2016/08/29/group-wantsback-temple-but-endowment-board-says-no/\#tvqMCUqhVktUE3jU.99.

The Stateman. 26 December 2007. "Malaysia to Protect Hindu Temples." The Statesman, 26 December 2007, 1.

Tjosvold, Dean, and Ted L Huston. 1978. "Social Face and Resistance to Compromise in Bargaining." The Journal of Social Psychology 104 (1):57-68.

Tregonning, K. G. 1966. "The Early Land Administration and Agricultural Development of Penang." Journal of the Malaysian Branch of the Royal Asiatic Society 39 (2 (210)):34-49.

Tully, John. 2011. The Devil's Milk: A Social History of Rubber: NYU Press.

Turnbull, Constance Mary. 1972. The Straits Settlements, 1826-67: Indian Presidency to Crown Colony: Athlone Press.

Turner, Harold W. 1979. From Temple to Meeting House: The Phenomenology and Theology of Places of Worship. Edited by Leo Laeyendecker and Jacques Waardenburg. Vol. 16, Religion and Society. The Hague: Mouton Publisher.

Utusan Online. 26 February 2016. "Wakaf Tanah Untuk Rumah Rakyat." Utusan Online, Rencana.

Vatikiotis, Michael. 1992. "The Dap Dilemma." Far Eastern Economic Review 155 (9):24.

Vertovec, Steven. 2000. The Hindu Diaspora: Comparative Patterns. London and New York Routledge.

Whitehouse, Harvey. 2005. "Emotion, Memory and Religious Rituals: An Assessment of Two Theories." In Mixed Emotions: Anthropological Studies of Feeling, edited by Kay Milton and Maruska Svasek, 91-108. Oxford and New York: Berg Publishers. Willford, Andrew C. 2007. Cage of Freedom: Tamil Identity and the Ethnic Fetish in Malaysia. Singapore: NUS Press.

---. 2013. "The Letter of the Law and the Reckoning of Justice among Tamils in Malaysia." In Encountering Islam: The Politics of Religious Identities in Southeast Asia, edited by Yew Foong Hui, 133-57. Singapore: Institute of Southeast Asian Studies. 
Wilson, Boyd H, and Jami Becksvoort. 2001. "Gopurams over Georgia: Why Here? Why Now?" In Hindu Diaspora: Global Perspectives, edited by T. S. Rukmani, 329-48. New Dealhi: Munshiram Monoharlal.

Winzeler, Robert L. 2016. "Three Versions of Popular Hinduism." In Popular Religion in Southeast Asia, 55-86. London: Rowman \& Littlefield.

Younger, Paul. 2010. New Homelands: Hindu Communities in Mauritius, Guyana, Trinidad, South Africa, Fiji, and East Africa. New York: Oxford University Press 